AMERICAN
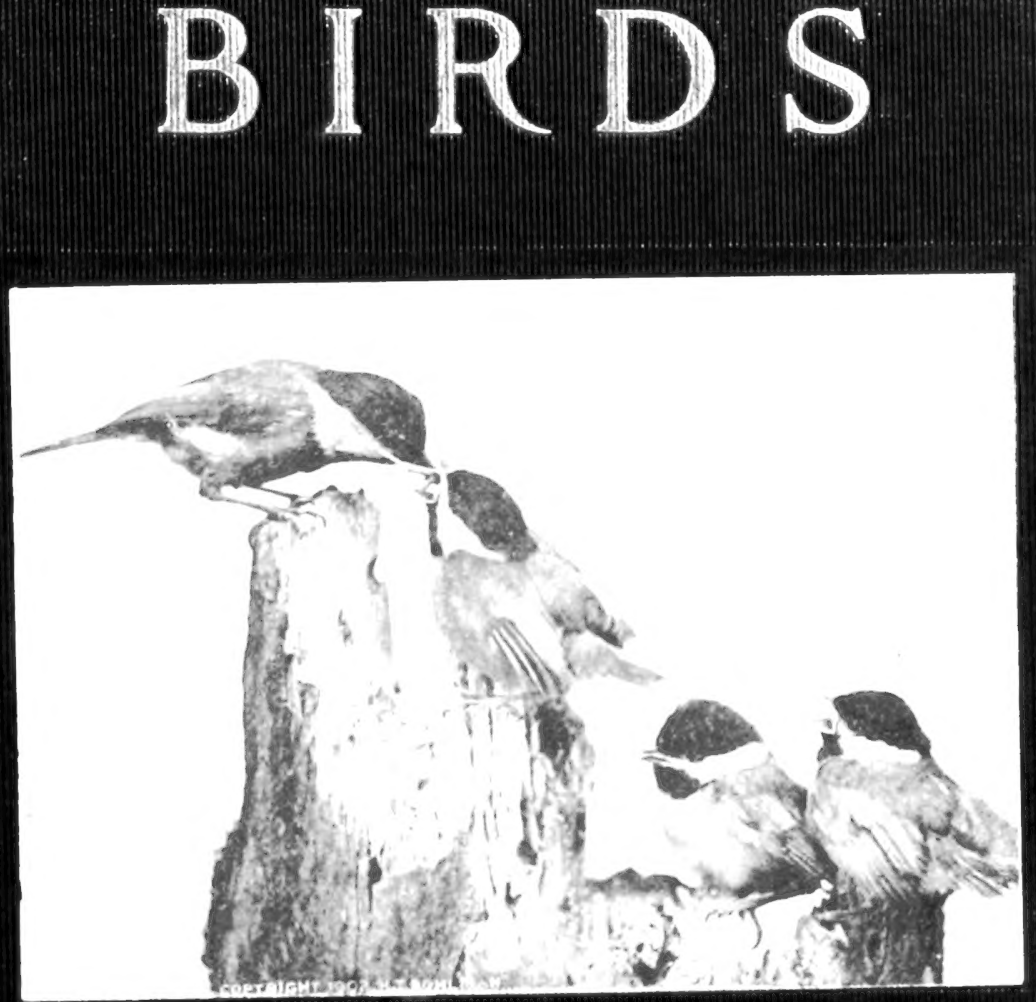

\title{
PHOTOGRAPHED AND STUDIED FROM LIFE
}

\section{WILLIAM LOVELL FINLEY}




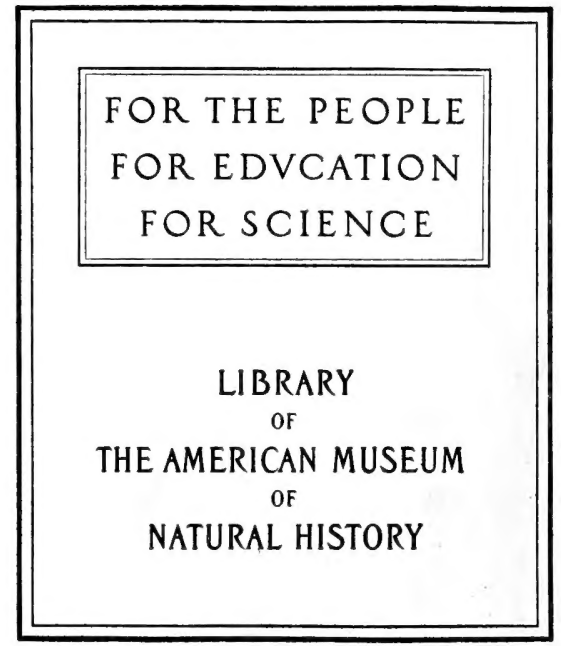



. 
AMERICAN BIRDS 



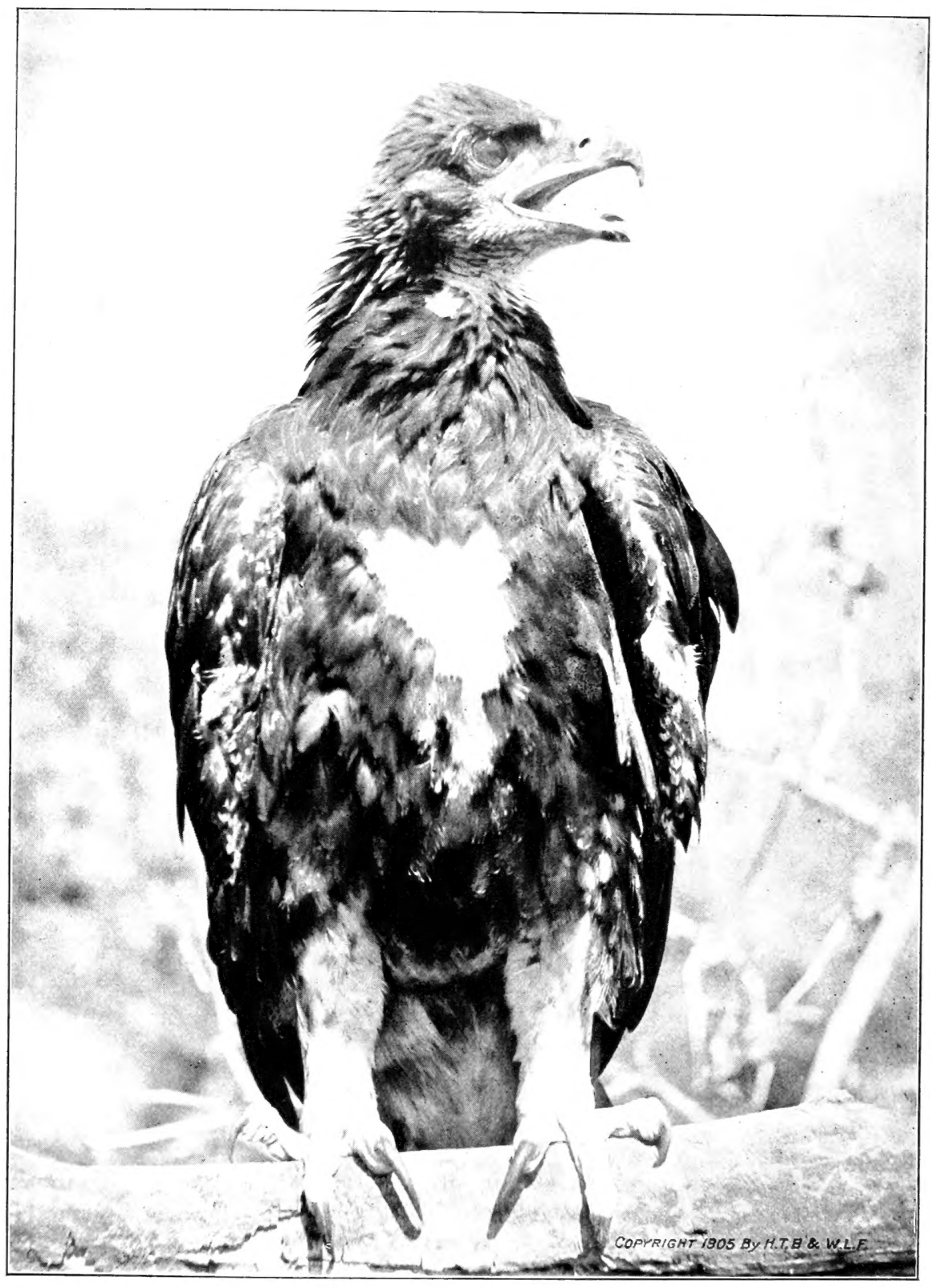

Joung (iolden Eagle, not quite fully fledged.

White donn still showing on breast. 


\section{AMERICAN BIRDS}

\section{STUDIED AND PHOTOGRAPHED \\ FROM LIFE}

BY

WILLIAM LOVELL FINLEY

ILLUSTRATED FROM PHOTOGRAPHS BY

HERMAN T. BOHLMAN

AND THE AUTHOR

CHARLES SCRIBNER'S SONS

NEW YORK ::::::::::::::::::::: 1908 
Copyright, I907, BY

CHARLES SCRIBNER'S SONS

\% $168 \%$. H.

Published, October, 1907

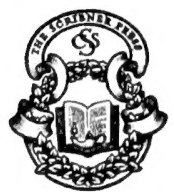


TO

MY MOTHER 


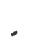




\section{PREFATORY NOTE}

AN important and sometimes difficult phase in the study of bird life is to observe accurately and report without false interpretation the habits and actions of birds. The naturalist who uses the camera in the field often has the advantage of backing his observations with proof (not an unimportant thing in nature writing of to-day), and if he produces good authentic photographs, one may be quite sure they were not secured without patient waiting and a careful study of his subjects.

In this book no attempt has been made to include all the different bird families, but a series of representative birds from the hummingbird to the eagle has been selected. Each chapter represents a close and continued study with camera and notebook at the home of some bird or group of birds, - a true life history of each species. It is the bird as a live creature, its real wild personality and character, that I have tried to portray.

Many of these studies were made in the West, but in the list of birds treated an effort has been made to get a selection that is national in scope. In the popular mind a song sparrow is a song sparrow from ocean to ocean, yet scientifically he represents over a dozen subspecies, 
according to the part of the country in which he lives. To the ordinary bird lover, however, a robin is the same east and west, and the same is true of the chickadee, flicker, wren, grosbeak, vireo, warbler, hawk, and others dealt with in the following chapters.

In making this book, I have used many suggestions offered by my wife, and I have had her valued assistance and criticism.

In studying bird life, I have been closely associated with Mr. Herman T. Bohlman since boyhood. He has been my constant companion and helper in the field every summer for the past ten years. I owe much to him, for this book embraces the chapters in his experience as well as in mine.

Portland, Oregon,

William L. Finley.

August, 1907. 


\section{CONTENTS}

I. The Hummingbird at Home • • . $\quad \begin{array}{r}\text { page } \\ 3\end{array}$

II. The Chickadee • • • • • • - 15

III. Photographing Flickers • • • • 25

IV. The Yellow-throat • • • • • 35

V. A Family of Grosbeaks • • • • 45

VI. The Red-Tailed Hawk • • • • 57

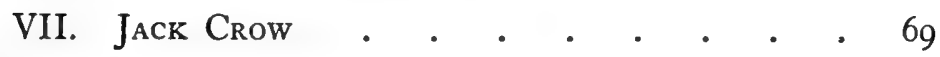

VIII. The OWL, Bird of Night • • • • 81

IX. Rearing a Wren Family . . . . • 9 I

X. The Weaver of the West . . . . . 105

XI. Jimmy the Butcher-Bird • • • • • II5

XII. The Warbler and His Ways • • • 127

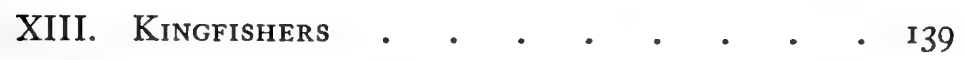

XIV. SParrow Row . • • . . . . . I5I

XV. Two Studies in Blue • . • • . . ${ }^{-} 6_{3}$ 
XVI. Basket Makers, the Vireo and Oriole $\quad \begin{array}{r}\text { page } \\ \text { I75 }\end{array}$

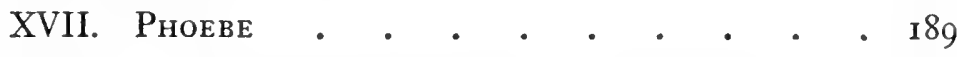

XVIII. A Pair of Cousins-Robin and Thrush $\quad$ I99 XIX. Gull Habits • • • • • • • • 2 . 2 I XX. In a Heron Village • • • • • • 221 XXI. The Eagle of Mission Ridge • • • 235

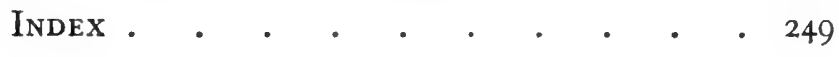




\section{ILLUSTRATIONS}

Young Golden Eagle, not quite fully fledged. White down still showing on breast . . . Frontispiece

The Hummer saddled her cup on the lowest branch of a $\underset{P \text { AACE }}{\text { FAcrisc }}$ small fir . . . . . . . . . 5

Mother Hummingbird on edge of nest about to brood young • • • • • • • • • • . 5

The nestlings began to fork out all over with tiny black horns . . . . . . . . . • . 5

The Hummer feeding her young by regurgitation. She jabs her long bill down the baby's throat and injects him with honey . • • • . . • • • • 5

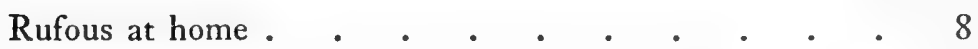

Young Hummer on the clothes-line in the back yard . . 12

Young Hummers about to leave nest . • . . . 12

Hummingbird poised in mid-air, taking food from the

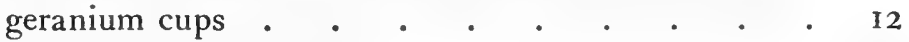

Nest and eggs of Chickadee . . . . . . . ${ }^{\text {I7 } 7}$

Chickadee at the threshold of her home - . . . I7

Mother Chickadee at back door of her nest . . . 17

"Here we are! We are seven!" . . . . . . 2I

Chickadees in a family jar . . . . . . . 2 I

Photographing the Flickers' nest . • • . • . 28 
They liked to cling to our clothing - . - . 28

Nest and eggs of Flicker, with side of stump sawed out $\quad 28$

"About face!" . . . . . . . . . . . 32

A family of young Flickers . • . • . . . 32

Flicker at the front door of her home . . . . . 32

Male Yellow-throat • • • • • • • • • 39

The mother came with a big spider . . . . 39

Nest and eggs of Yellow-throat . . . • . • 39

The mother dropped to the perch, and gave the nearer one

a big caterpillar . . . . . . . 40

Young Yellow-throats quarreling . . . . . 40

Mother Grosbeak feeding young . • • • • 49

Male Grosbeak feeding young • • • • . • 49

Nest of eggs of Black-headed Grosbeak • • • 52

Male Grosbeak at nest • • • • • • . 52

Grosbeak babies . . . . . . . . 52

A full-grown young Red-tail. The tail end of a carp showing in the nest . . . . . . . . 57

Taking pictures at the aerie of the Red-tail, I 20 feet from

the ground . . . . . . . . 58

At the foot of the Hawk's tree - . . . . $5^{8}$

Aerie of the Red-tail in the tall cottonwood. . . $\quad 5^{8}$

Nest and eggs of the Red-tail, April I5th . . . . 6r

Young Red-tails in the downy stage, May $3 \mathrm{~d}$. . . 6I

Full-grown young Red-tails just before they left the aerie, May 24th. Piece of carp showing in nest 


\section{Illustrations}

Young Crows just after hatching • . . . . 72

Nest full of young Crows, about half-grown . • $\quad 72$

Jack Crow's perch in the apple tree . . . . . 72

"Granny"-a portrait of a half-grown Barn Owl . . 8I

Full-grown young Barn Owls at the age of eight weeks . 85

Nest and eggs of the Barn Owl . . . . . . 85

Downy young Barn Owls about three weeks old • . 85

A study in sentiment $\quad$ •

Barn Owl in full flight

Half-grown Barn Owls, about six weeks old • . $\quad 88$

Young Barn Owl in fighting attitude . . • • . 88

Wide awake and on the tip-toe of expectancy . . $\quad$ - 92

Mother Wren at the nest hole • • . . . 96

A young Vigors Wren just after leaving nest in the dead alder $\quad 96$

Feeding young Wrens • • • • • • • 996

The parents lit wherever they found the children . . 105

Bush-tit feeding young on top of cap . . . . . 105

Awaiting their turns-rather impatiently . . . . 105

Bush-tit at door of long hanging nest . . . . . 108

Young Bush-tits beside long pendent nest . . . . 108

Male Bush-tit with green cutworm for young . . . 108

Jimmy • • • • • • • • • • • • II6

Jimmy eating from the hand of his mistress . . . II6

Pair of young Shrikes or Butcher-birds . . . . II6

He often perched in the pear tree . . . . . II6 
xiv

Nest and eggs of Black-throated Gray Warbler . . . 128

Two small nestlings • • • • • • • • • 128

Disputing while mother is away . . . . . $\quad$ 128

The mother often brought in green cutworms . . . 133

The gray mother rewarded him with a mouthful . . 133

She did not forget the hungry, more timid fledgling in the

nest • • • • • . • • • • • 133

Taking a portrait of a young Kingfisher . . . . 140

The Kingfisher with a broken bill . . . . . . I40

The first day out of the nest fully fledged . . . . 140

Six of the frowsy-headed Fishers in a pose . . . $\quad 145$

The door to the Kingfisher's home showing small hole to the left where nest was first started; the two little tracks at the bottom made by the feet of the bird . . $\quad$ I45

They perched on the projecting snags over the water - 145

Song Sparrows about to break home ties . • . • I52

An English Sparrow, actually making a home in a hornet's nest • • • • • • • • . • • 156

Nest and eggs of the Song Sparrow . . . . . 156

Song Sparrow on a fence. One of our most constant singers 156

The White-crowned Sparrow father with food for young • 160 Female White-crowned Sparrow . . . . . . 160

Female White-crowned Sparrow with food for young. 160

A pair of White-crowned Sparrows . . . . . 160

Young Blue Jay in nest • • • • • • • 165

The Bluebird mother at the nest hole . . . . 165 
Young Blue Jay just leaving nest .

The young Bluebird was just in the act of jumping for the worm the mother held

The male Bluebird with food for young • . . $\quad$ I 72

A Mother Bluebird poising an instant after feeding her young • • • • • • • • • • • • 172

Mother Oriole feeding young • • • • . . 177

Basket nest of the Oriole. A door has been cut in the wall

of the nest to show the eggs . . . . . . 177

Young Cassin Vireos on branch over basket nest . $\quad$ I77

Cassin Vireo beside nest . . . . . . . . I80

Warbling Vireo feeding young • • • • • $\quad$. 180

Warbling Vireo at nest after feeding . . . . . 180

Phœbe and young on the wire of the fence . . . . 193

Young black Phobes in nest . . . . . . . 193

Two young black Phobes just after leaving nest . . 193

Mother Phœbe feeding young . . . . . . 193

The Thrush's nest among the ferns . . . . . 200

The Thrush on her nest . . . . . . . . 200

The Thrush mother at the nest edge . . . . 200

Young Thrush on a wild raspberry . . . . 200

Young Robins at home . . . . . . . 208

A Robin in the cherry tree . . . . . . . 208

Nest and eggs of the Gull . . . . . . . 212

The perfect poise of the Gull . . . . . . 212

Young Sea Gulls in the nest . . . . . . . 212 
A Gull at home on the rocks . . . . . . 212

A pair of Gulls on the wharf . . . . . . 214

Gull just catching a bite that is thrown to it . . . 214

Tame Gulls about the beach . . . . . . 214

Gulls perched on the anchor chain awaiting dinner . 2 I6

Great Blue Herons coming home from the marshes • $\quad 225$

Family of young Great Blue Herons in tree-top nest . $\quad 225$

Young Great Blue Heron . • • • • , 225

Great Blue Heron in top of sycamore beside nest $\quad$ - 225

Full-grown young Night Heron . • • • • 229

Using a reflex camera in the tree-tops among the Herons . 230 Black-crowned Night Heron on nest . . . . 230

Young Night Heron clinging to limb . • • . . 230

Nest and eggs of the Golden Eagle . . . . $23^{6}$

Working at the aerie of the Golden Eagle. The nestlings about three-fourths grown. The nest is five feet across $23^{6}$ Photographing the Golden Eagle's nest . . . ${ }^{2} 3^{6}$ Downy white Eagles at the age of twenty-five days . 240 Mottled young Eagles at the age of forty days . • . 240 The royal twins at the age of fifty-five days . . 240

Pair of young Golden Eagles at the age of sixty-two days 240 


\section{THE HUMMINGBIRD AT HOME}




\section{I}

\section{THE HUMMINGBIRD AT HOME}

$\mathrm{H}^{\mathrm{E} \text { dropped into our garden like the flying fleck from }}$ 1 a rainbow, probed at the geranium blossoms and disappeared as the flash from a whirling mirror. I had often watched him and listened to the musical hum of his wings, as it rose and fell in sweetest cadences. I always had the unsatisfied tinge of disappointment as I was left gazing at the trail of this little shooting star of our garden, that hummed as well as glowed. I longed to have him and call him mine. Not caged, mercy no! I wanted his lichen-shingled home in the Virginia creeper, his two pearly eggs, the horned midgets, the little fledglings, the mother as she plied them with food, and I wanted the glint of real live sunshine that hovered and poised about the flowers and got away, a minute ethereal sprite. And more than that, I wanted to have forever with me this mite that possesses the tiniest soul in feathers.

It was not till we had studied, had watched and waited with the camera for four different nesting seasons about the hillside and along the creek, that we succeeded in getting a series of pictures of the home life of the little Rufous Hummingbird (Selasphorus rufus) ${ }^{1}$.

The first year, by the merest chance, we found a nest

I For a description of the more important species in each family the reader is referred to the end of the chapter. 
that had been placed in a wild blackberry brier just above the creek. The green fibres and the lichens that shingled the outside of the tiny cup blended exactly with the green leaves and stems of the vines. The cotton lining of the nest and the two eggs looked precisely like the clusters of white blossoms surrounding. One might have searched all over the vine a dozen times and yet not have discovered the nest.

Many a spider's suspension-bridge the hummingbird had torn away, and many a mouthful of cotton from the balms and down from the thistles, she collected. As I watched her, it looked to me as if a bill for probing flowers was not suitable for weaving nests. Maybe it would have been more convenient at times if it had been shorter. But she wove in the webs and fibres. She whirred round and round and shaped the side of her cup as a potter moulds his masterpiece. Then she thatched the outside with irregular bits of lichen.

Another pair of hummers took up a homestead on the hillside. The bank had been cut down to build a wood road, but the place had been abandoned a generation ago. The hummer saddled her tiny cup on the lowest branch of a small fir at the top of the bank. It looked as if she had picked out a spot to please the photographer.

When the weather was warm, the mother didn't brood long at a time. It often looked to me as if it was only child's play at setting. Five minutes was such a long, wearisome spell that she just had to take a turn about the garden. I often thought the tiny eggs would chill through before she returned, and I began to lose hope in her restless, shiftless manner. But she knew better. 



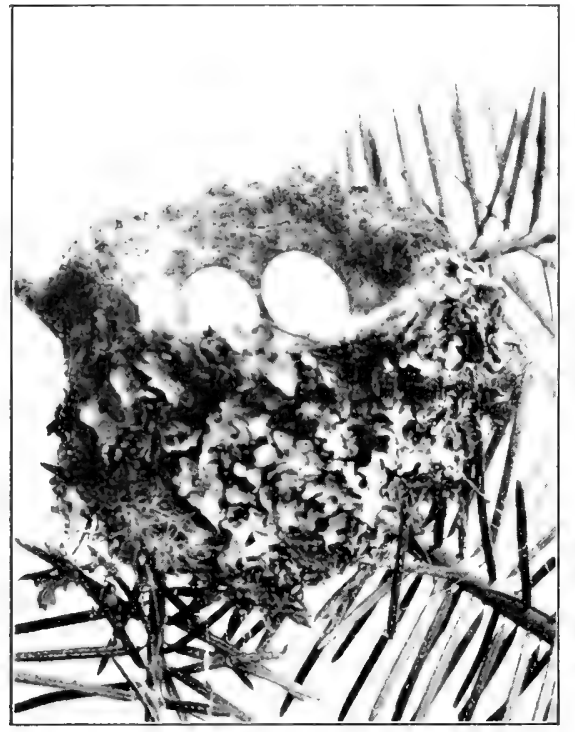

The Hummer saddled her cup on the lowest branch of a small fir.

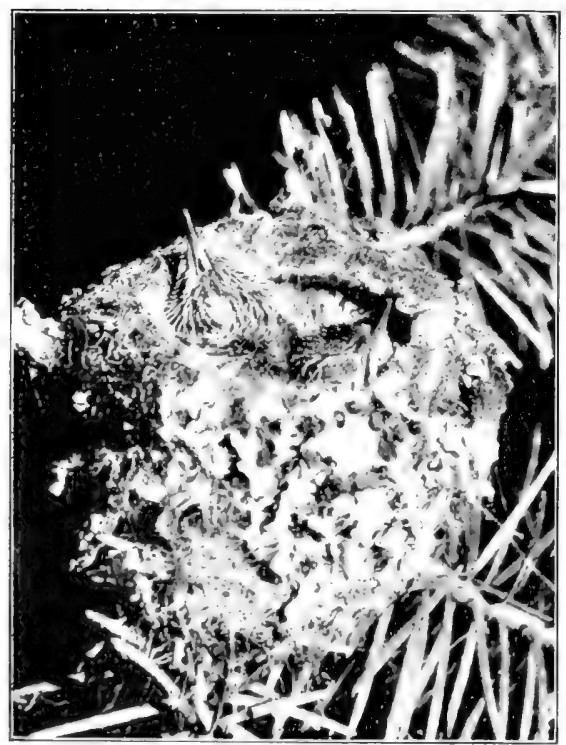

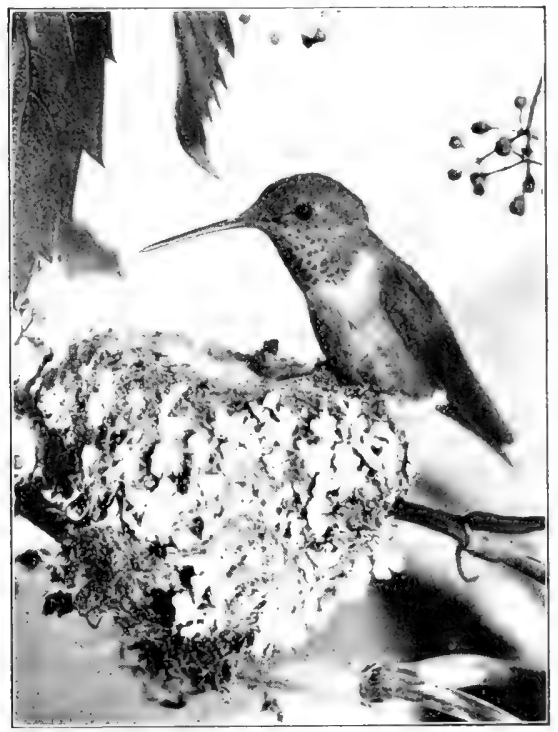

Mother Hummingbird on edge of nest about to

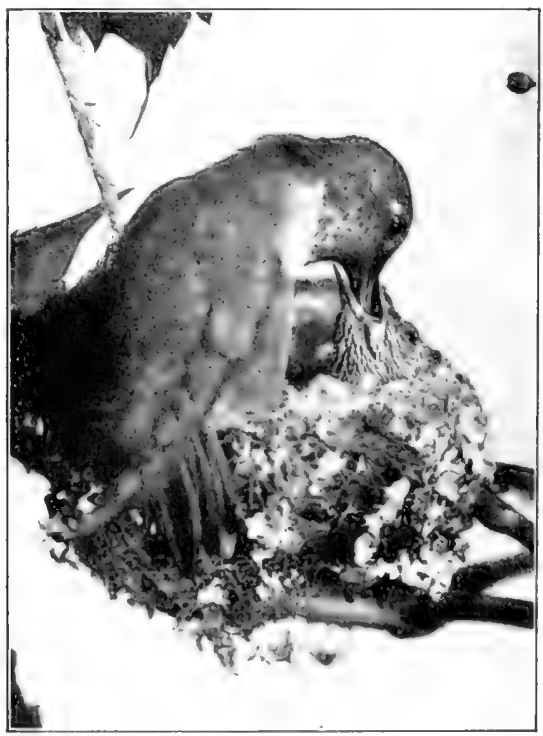

The mestlings tugran en fork out all over with tiny black horns.
The Hummer feeding her young by regurgitation. She jabs ber long bill down the baby's throat 
At first the little capsules had such a wonderfully delicate flesh-tint of pink. Then, one morning, I stood over the nest like Thomas of old. Some one had replaced the eggs with two black bugs! It might have been a miracle. There was a tiny knob on the end of each bug that looked as if it might be the beginning of a bill. Each little creature resembled a black bean more than a bird, for each possessed a light streak of brown along the middle of the back. They couldn't be beans, for they were pulsing with life in a lumpy sort of way. I went frequently to look at them. In a few days the nestlings began to fork out all over with tiny black horns, until they would have looked like prickly pears had they been the right color. At the next stage each tiny horn began to blossom out into a spray of brown down, the yellow at one end grew into a bill, the black skin cracked a trifle and showed two eyes. It was hard to see just how those black bugs could turn to birds, but day after day the miracle worked till I really saw two young hummingbirds.

When they left the nest, the midgets took up their abode in our back yard. The yard was crossed by three clothes-lines for perches, and the large apple tree in the corner gave abundant shade for the hottest days. In the centre was a round bed of geraniums, and along the fence were gladioli and nasturtiums. The youngsters simply sucked all the honey out of every flower in the yard. Every morning I saw them going the rounds and collecting tribute from the hearts of the new blossoms. As I came and went about the house, they soon became accustomed to the presence of a person, and when I filled some flowers with sweet water, it did not take them long to 
recognize that the flowers in the hand were better than those on the bush.

Then one day I dipped my finger in sweetened water and held it up to one of the twins as he sat on the line. I was amused, for such a treat came to him as a complete surprise. Before that, when a finger was put up near his nose, he poked it, but found nothing attractive; now his little tongue darted out and hauled in the sweet. The next instant he was buzzing about my face and neck, poking for honey. He seemed as enthusiastic as a man who had suddenly strtick a new mine, for it all looked alike to him. If one part was sweet, perhaps it all was, and it was high time he was knowing this new source of food, for he had seen such things as people before.

One morning I found one of the young hummers sitting muffled up on the clothes-line, sound asleep in the sun. The instant I touched the line he awoke as if from a bad dream, and was all excitement. I didn't have any sweetened water, but I picked up a ripe plum, tore the skin away, and held it up. In went the sharp bill, but it came out with thrice the rapidity. Such a face! He almost fell backward off the perch and nearly shook his head off, scolding in a little squeaky voice all the time.

It was amusing to watch the little fellows, for each had his own perch on a separate line and every once in a while, when one went too near the perch of the other, there was a little friendly bout and they darted back and forth, chasing each other in the sunshine. But, as the days passed, I noticed these little conflicts seemed to grow more serious. One would dart at the other, and round and round the yard they would go, whizzing and screeching, 
and then away. Before long one of the twins ceased to come at all.

I don't believe any sun-worshipper of old could be more devoted to his idol than the hummingbird. He lives in the sun almost as a fish does in the water. The minute a cloud crosses the face of the sun his feathers puff up and his eye loses its sparkle. It's hard for a hummer to endure cold and cloudy weather, much more a season of rain. But he seems to adapt himself better to a rainy climate than many other birds. He has profited by the experience of the past. Out of twenty-three different hummingbird nests, I found the majority built so that they were entirely under shelter. Three were in vines directly under bridges, two in Virginia creepers under porches, another in a blackberry bush under a $\log$, and so on, every time in a place where no amount of rain could bother them.

I was standing on the hillside one bright May morning when two hummers caught my attention. One whirred downward like the rush of a rocket. He ascended, whirling up till I could see only a blurred speck in the blue. Then he dropped headlong like a red meteor, with his gorget puffed out and his tail spread wide. Instead of striking with a burst of flying sparks, he veered just above the bushes with a sound like the lash of a whip drawn swiftly through the air, and, as the impetus carried him up, a high-pitched musical trill burst out above the whir of his wings. Again and again he swung back and forth like a comet in its orbit. If he was courting, his aim was surely to dazzle and move with irresistible charm. I think his method was to sweep at his lady love with a show of glittering brilliancy and gorgeous display and win her heart 
in one grand charge. He must have won her, for the pair built a home in the Virginia creeper. They took one of the loose strings that had been used to tie up the vines and wove it into the fabric of their home; if the floor beneath gave way, they would surely have a support from above.

The way the mother would light on her nest was a marvel to me. She always stopped on the dead twig of a maple before dropping to her home. I saw her do it several times. She came at the nest like a meteoric streak. I held my breath lest the whole thing be splintered to atoms, for she hit the little cup without the slightest pause that I could see, yet she lit as lightly as the touch of floating thistle-down.

Below the hummer's nest the water trickled down the basin of the cañon. In places it formed pools and dropped over the rocky edges. One of these tiny basins was the hummer's bath-tub. It was shallow enough at the edge for her to wade. For a moment her wing-tips and tail would skim the surface, and it was all over. She dressed and preened with all the formality of a queen. After the bath I watched her circle about the clusters of geraniums and drink at the honey cups of the columbine. She seemed only to will to be at a flower and she was there; the hum of the wings was all that told the secret. She was a marvel in the air. She backed as easily as she darted forward. She side-stepped, rose, and dropped as easily as she poised.

While the nestlings were very young the mother never left them alone long at a time. If the day was warm, if the sun shone on the nest, the mother hovered over with 


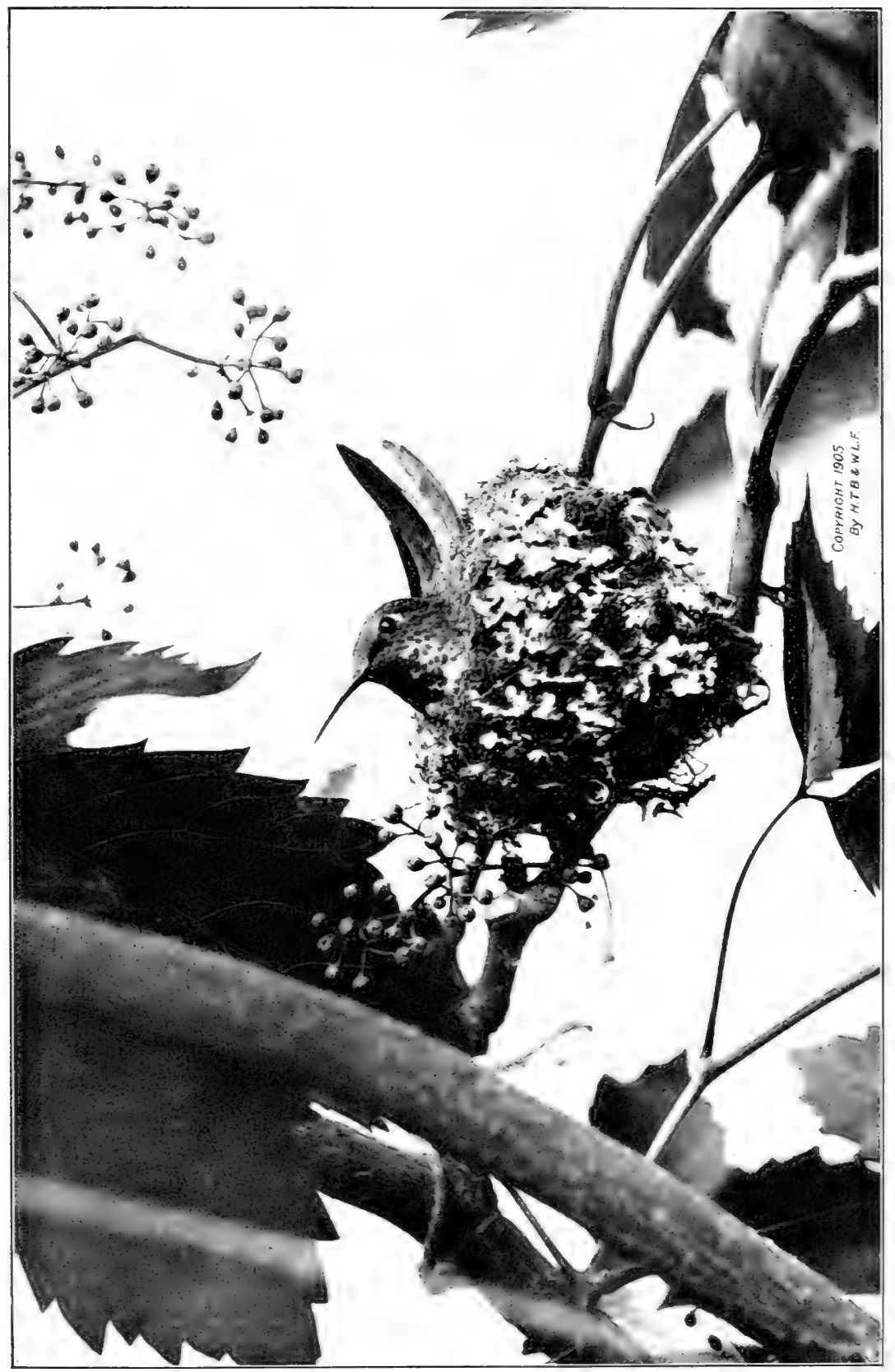




\section{The Hummingbird at Home}

wings and tail spread wide. When it was hottest, I've seen the mother sit forward on the nest edge, spread her tail till she showed the white tips of her feathers, and keep up a constant quivering, fanning motion with her wings to give protection to the frail midgets in the nest.

When I first crawled in among the bushes close to the nest the little mother darted at me and poised a foot from my nose, as if to stare me out of countenance. She looked me all over from head to foot twice, then she seemed convinced that I was harmless. She whirled and sat on the nest edge. The bantlings opened wide their hungry mouths. She spread her tail like a flicker and braced herself against the nest side. She craned her neck and drew her daggerlike bill straight up above the nest. She plunged it down the baby's throat to the hilt and started a series of gestures that seemed fashioned to puncture him to the toes. Then she stabbed the other baby till it made me shudder. It looked like the murder of the infants. But they were not mangled and bloody: they were getting a square meal after the usual hummingbird method of regurgitation. They ran out their slender tongues to lick the honey from their lips. How they liked it! Then she settled down and ruffled up her breast feathers to let her babies cuddle close to her naked bosom. Occasionally she reached under to caress them with whisperings of mother-love.

I have never seen a hummingbird fledgling fall from the nest in advance of his strength as a robin often does. When the time comes, he seems to spring into the air full grown, clad in glittering armor, as Minerva sprang from the head of.Jove. While I lay quiet in the bushes I learned 
the reason. One youngster sat on the nest edge, stretched his wings, combed his tail, lengthened his neck, and preened the feathers of his breast. Then he tried his wings. They began slowly, as if getting up steam. He made them buzz till they fairly lifted him off his feet; he had to hang on to keep from going: he could fly, but the time was not ripe. A little gnat buzzed slowly past within two inches of his eyes. The nestling instinctively stabbed at the insect, but fell short. Each bantling took turns at practising on the edge of the nest, till they had mastered the art of balancing and rising in the air.

I have never known exactly what to think of the male rufous. I never saw such an enthusiastic lover during the days of courtship and the beginning of house building. $\mathrm{He}$ reminded me of a diminutive whirlwind that took everything by storm. He simply ran crazy-mad in love. As soon as the cottony cup was finished and the mother had cradled her twin white eggs the father disappeared. He merely dropped out of existence, as Bradford Torrey says of his ruby-throat, leaving a widow with the twins on her hands.

This always seems to be the case, for at the different nests where I have watched, I never but once saw the male hummer near the nest after the children were born. I was lying in the shade of the bushes a few feet from the nest one afternoon. For two whole days I had been watching and photographing and no other hummer had been near. Suddenly a male darted up the cañon and lit on a dead twig opposite the nest. He hadn't settled before the mother hurtled at him. I jumped up to watch. They shot up and down the hillside like winged bullets, through 
trees and over stumps, the mother with tail spread, all the while squealing like mad. It looked like the chase of two meteors that were likely to disappear in a shower of sparks had they struck anything. If it was the father, he didn't get a squint at the bantlings. If it was a bachelor awooing, he got a hot reception.

I can't believe the male rufous is an intentional shirk and deserter. I think that somewhere back through the generations of hummingbird experience, it was found that such bright colors and such devotion about the home were clews unmistakable for enemies. It is, therefore, the law of self-protection that he keep away entirely during the period of incubation and the rearing of the young.

\section{THE HUMMINGBIRD FAMILY}

This is a family of birds easily recognized because they are the smallest in size. They have tiny feet and long slender bills to suck the nectar from the flowers. They flit through the air with great rapidity, their buzzing wings giving the bird the appearance of an insect.

Ruby-throated Hummingbird (Trocbilus colubris): Male, above, green; below, grayish-white; wings and tail, ruddy black; shining rubyred patch on throat. Female, colors less showy and throat-patch lacking. Summer resident along the Atlantic Coast, arriving the first of May and remaining till October. Nest, a tiny cup saddled on a limb. Eggs, two in number, pure white and about the size of soup beans.

Rufous Hummingbird (Selasphorus rufus): Male, general color above and below, bright reddish-brown, with more or less green on top of head and sometimes extending on back; throat, glancing coppery red, below fading into white. Female, similar to male but more brownish in color; throat with just a tinge of red. Summer resident of the north Pacific Coast, arriving in April. Nest and habits, similar to those of Ruby-throat.

Anna Hummingbird (Calypte anna); Top of head with metallic, 
iridescent scales same as throat. Feathers of throat prolonged in a ruff. Back and middle tail feathers greenish without any rufous or white. Tail forked. Adult female similar, except on head and tail. No metallic scales on head, but greenish like back. Throat specked with rose. Common resident throughout California. 


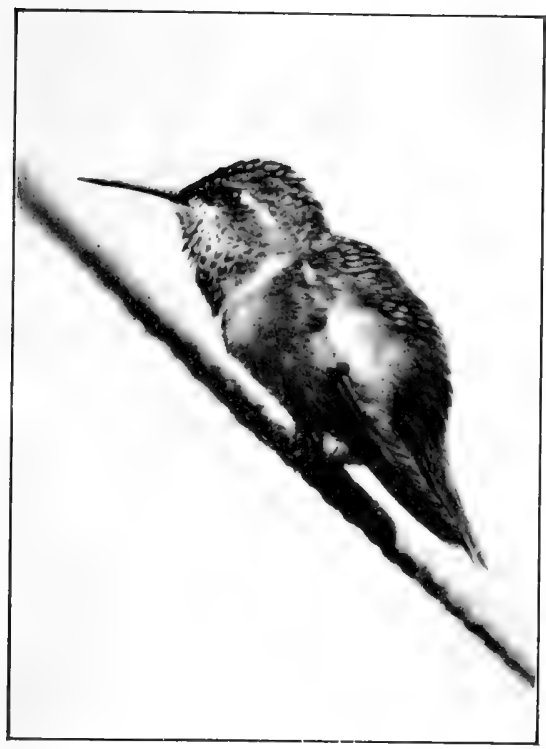

Young Hummer on the clothes-line in the back yard.

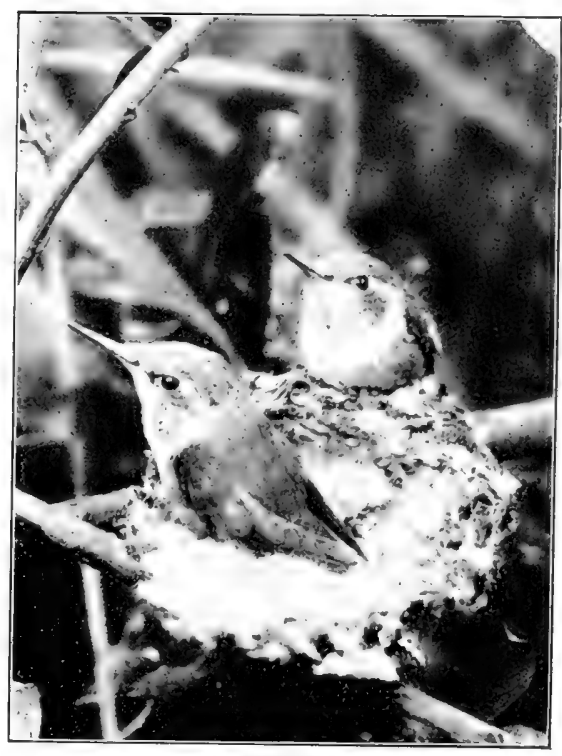

Young Hummers about to leave nest.

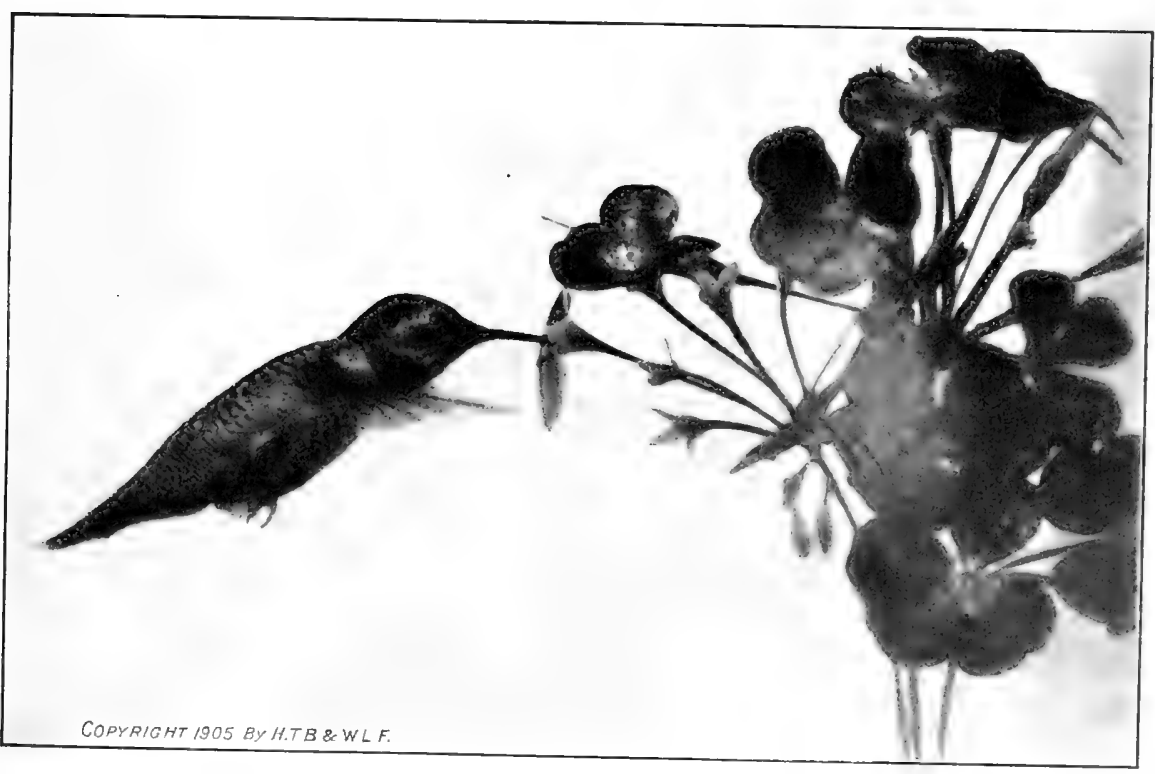

Hummingbird poised in mid-air, taking food from the geranium cups. 


\section{THE CHICKADEE}




\section{$\checkmark$}

I 


\section{II \\ THE CHICKADEE}

$7 \mathrm{HE}$ air was crisp. The snow crunched under foot. The waters of Fulton Creek slid noiselessly through the lush grasses that hung along the bank. The clump of tall firs up the hillside was roughly inked against the gray clouds. The dead hush of winter had crept up the cañon. Suddenly a sound like the tinkling of tiny bell-voices broke the stillness. Across the long, white stretch between the pointed firs scurried a whole troop of black and white fairies.

I was in the same place a little over three months later. The young firs stood in rows rising from the creek side, each topped with the brighter green of the new spring growth. The alders and dogwoods had suddenly split their buds, as if shame had shaken their naked limbs. The open glade shimmered with the diamond drops on the tender shoots of new grass. The air quivered with each sound and motion. Everything throbbed with expectancy. Where I had seen a dozen fairies, now I saw only two. Where the rest of the troop had gone, I do not know. This newly wedded pair seemed happy and contented.

I stood there and watched as one of the midgets whirled over to a nearer bush What was he doing there? He fidgeted about as if he had put something away and couldn't remember just where he had laid it. I looked 
around, but saw nothing save the wreck of an old alder; dead, rotten, useless, broken off five feet from the ground; not even good for fire-wood; worm-eaten at the bottom, almost ready to return as earth to the ground from which it had sprung. Rotten, but not entirely useless-it gave me an idea.

The little Black-capped Titmouse or Chickadee (Parus atricapillus occidentalis) is the most constant feathered friend I have, for there is hardly a day in the year that I cannot find him, whether it be hot or cold. On some of my tramps in the rain and snow the chickadee has been the only bit of bird life that has cheered my way. I have never found the chickadee moody. I've seen him when it was so cold I couldn't understand just how he kept his tiny body warm; when it looked like all hunting for him and no game. If he was hungry, he didn't show it. The wren goes south and lives in sunshine and plenty all winter. He goes wild with delight when he returns home in the spring. The chickadee winters in the north. He endures the cold and hunger of the dreary months. In the spring his cheer seems just the same. He doesn't bubble over. He takes his abundance in quiet and contentment.

Chickadee never seems to have the blues, but for all his cheer and happiness, the loneliest, saddest bird I ever saw was a chickadee who had lost his mate. It was cold and darkening. I heard the sad, drawn-out "phee-bee" note up the ravine. As he came nearer, it sounded like a funeral song. The bewildered little fellow was all aflutter and uneasy, flitting from tree to tree and calling, calling. I can hear the echo yet, calling for his love. 


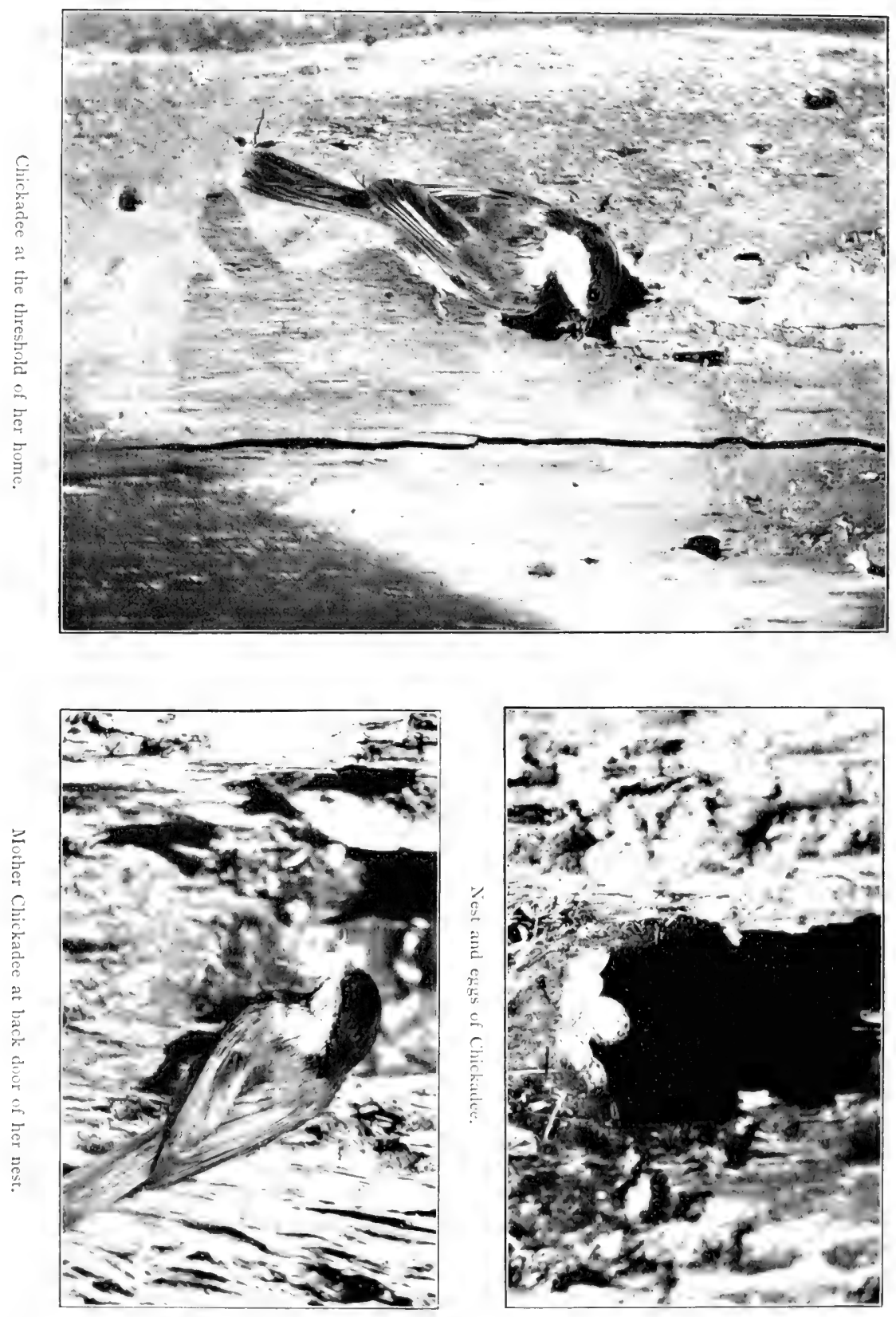
The glade up Fulton Creek just suited the chickadees. It was rarely invaded by troublesome people. Chickadee likes human society when the snow comes and food grows scarce in the woods, but just as soon as he falls in love and his mind turns to housekeeping, he looks for a quiet nook.

The next time I strolled up the creek, one of a newly wedded pair suddenly met me just where the path branched a few yards below the alder stump. I didn't see him come, but he appeared right on the limbs of the maple over the trail that led away from the nest. He didn't see me at all! The little trickster! He was very industriously pecking at nothing I could see with my field-glass. As soon as I stopped, he began turning and twisting, stretching his neck to look under a leaf. He hung by his toes, head down, and swung back up like a circus performer. Then he swung head down again, dropped, and lit right side up on the branch below. He made a high jump of over a foot, but grabbed nothing. And such unconcern! He never looked at me. I thought of the lad across the street, who, by his stunts, used to coax me out of the yard against orders. The little black-cap drew me now as the boy did then. "You're entertaining, but not so clever as you seem," I said, as I followed him off down the wrong path away from his nest.

I shall never forget the day we trudged up with the camera to get a picture of the eggs. When we reached the chickadee villa, the mother was at home. I knocked at the base, so she would leave. Then I shook the stub, but she did not take the hint. I took a little twig and poked in, trying to lift her up. She met my advance with a funny little sound, like a mad cat in a box. Drive her 
out of her own house? Well, I should say not! Finally I cut a piece right out of the back part of her house, where the wall was thin. There she sat without moving, while I focused my camera. The little black eyes showed a brave spirit that I have seldom seen in a bird. I carefully slid the piece back again and locked it with a string.

I knew she had done a heroic deed. I sat down under the tree to watch. As soon as all was quiet, she shot from the door like a winged bullet and struck right on the limb beside her mate who had been dee-dee-ing to her all the while. Of course, birds do not feel as we feel, but I don't believe a sweetheart ever met her lover returning from a field of battle with a greater show of joy. They simply threw themselves into each other's arms. It wasn't a silent meeting either; there were real cracks of kisses and twitters of praise. Chickadees are not human by any means, but had she not defended her home all alone against a giant?

A day or so later, I really did catch both the owners away from the nest and I counted one-two-three-four - five-six-seven dotted eggs on a cottony couch. When the mother returned she seemed so worried that I closed the door and started to leave in a hurry. But I hadn't stepped away more than ten feet before she was clinging at the doorway, and a moment later she popped into the hole and continued her brooding.

What if every egg should hatch, I thought. What could any mother and father do with seven children, all the same age? Think of it! Two pair of twins and a set of triplets, and not one of the youngsters able to assist in caring for brother or sister! 
I have often watched old birds feeding young, but I never had a good idea of just the amount of insect food they did consume till I watched the chickadees for a few days after the eggs hatched. Both birds fed in turn, and the turns were anywhere from three to ten minutes apart. From the time the chicks were born, the parents were busy from daylight to dark. They searched every leaf and twig along the limbs and trunk to the roots of every tree, under bark and moss, in ferns, bushes, and vines, and they hunted thoroughly. Such numbers of spiders they ate, and green caterpillars, brown worms, grasshoppers, daddy-long-legs, moths, millers, and flies, besides untold numbers of eggs and larvæ. Everything was grist that went to the chickadee mill. The way they could turn insects into feathers, placing the black and white pigment just where it belonged, was simply marvelous. A baby chickadee changes about as much in a day as a human baby does in a year.

One can readily count up how much insect life is destroyed each day, when the parents return every few minutes with food. Think how closely each bush and tree is gone over everywhere about the nest. One chickadee nest in an orchard means the death of hundreds and maybe thousands of harmful insects and worms every day. It more than pays for all the fruit the birds can eat in half a dozen seasons. But there are generally other birds nesting about. Think of the time when seven young chickadees are turned loose to search among the trees day after day during the entire year.

I spent two whole days at the nest before the chicks were ready to leave home. The owners of the stump seemed to think we had placed the camera there for their 
use, as they generally perched on the tripod. Then they always stopped a moment at the door before entering. The seven eggs had pretty well filled the nest. Now it looked too full. It seemed to me that if the little chicks kept on growing they would either have to be stacked up one on top of the other or lodged in an upper story.

Once the mother came with a white miller. She had pulled the wings off, but even then it looked entirely too big for a baby's mouth. Not a single nestling but wanted to try it. When the mother left, I looked in and one little fellow sat with the miller bulging out of his mouth. It wouldn't go down any further, but he lay back quite happy. His stomach was working at a high speed below; I saw the miller slowly slipping down until the last leg went in as the chick gave a big gulp.

The day was warm. We built a little perch at the front door, and set out one of the youngsters blinking in the sunshine. He soon felt at home. He liked it and seemed quite perked up and proud. Then we set out another and another-seven in all. It looked like a public dressing-room. Think of being crowded in the tiny hole of a hollow, punky stump with six brothers and sisters; jammed together with your clothes all wrinkled, not even room to stretch out, let alone comb and dress and clean yourself properly. They gave us a real chickadee concert, each trying to outdo the other. "Here-wcare! We-are-seven! Seven-are-we-dee-dee-dee!" Even the mother and father sounded a "Tsic-a-dee-dee" of joy as they fed from the perch instead of diving down into the little dungeon.

I believe there's more family love in the chickadee 



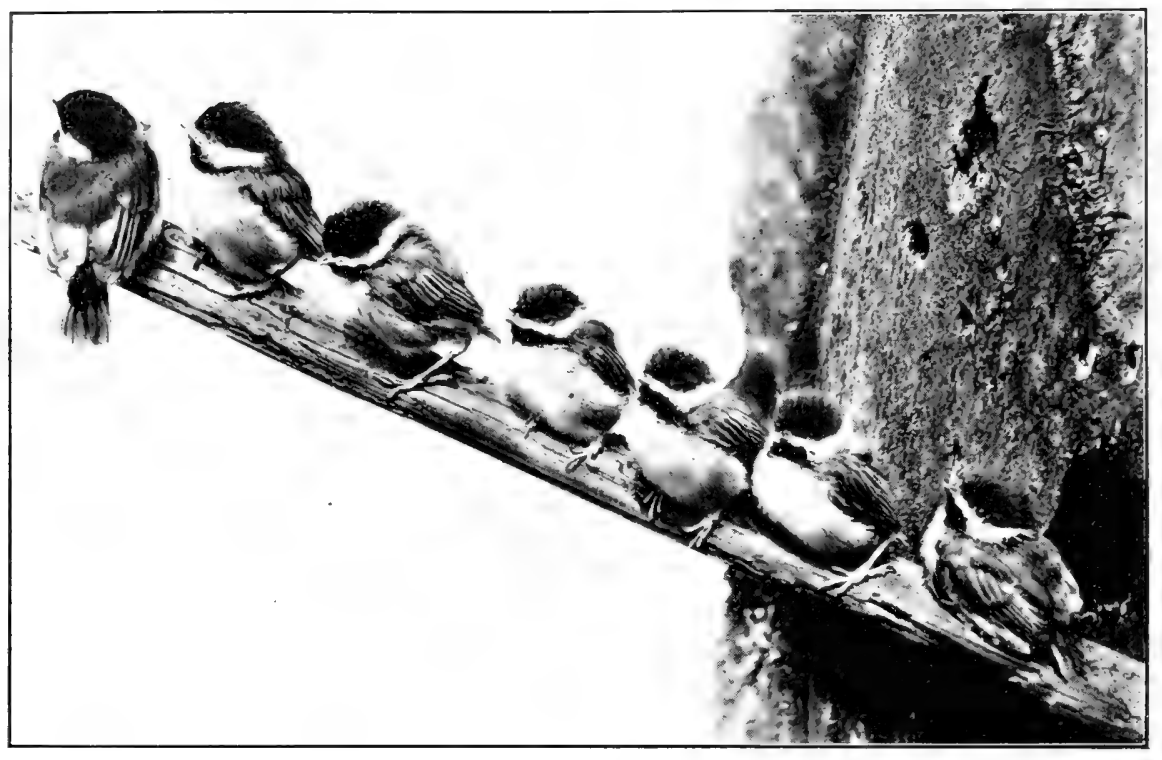

"Here we are! We are seven!"

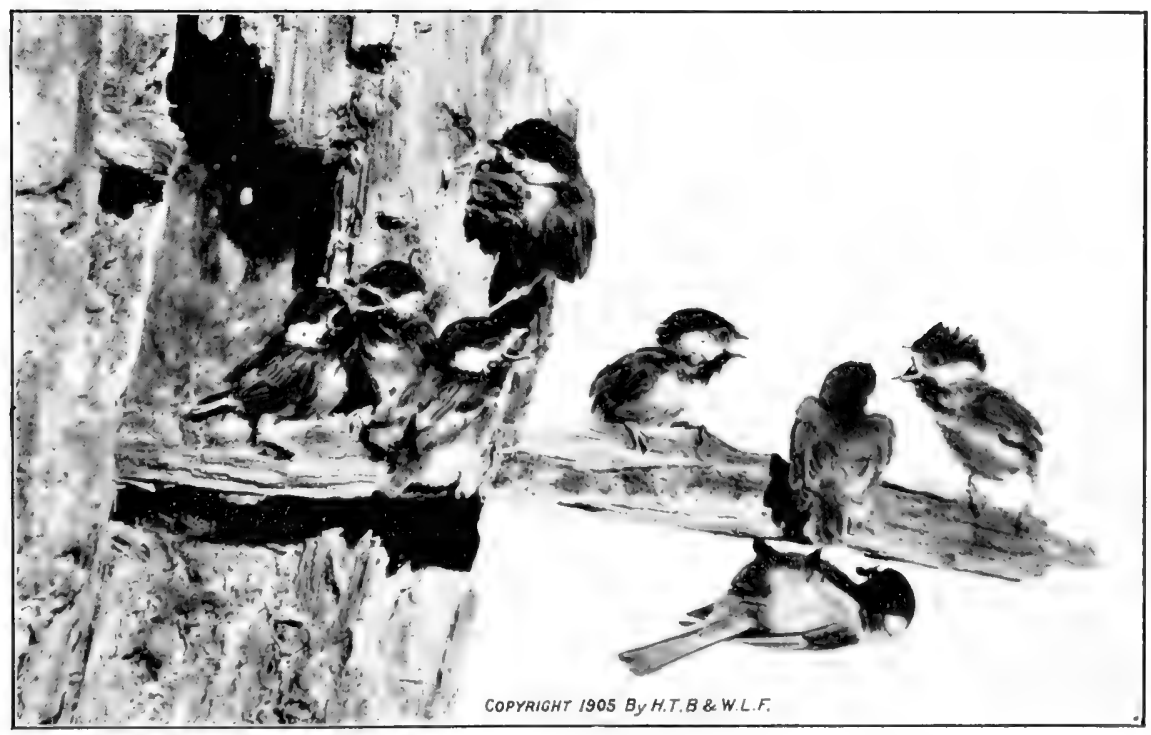

Chickadees in a family jar. 
household than in any bird home I have visited. I have seen a young flicker jab at his brother in real madness, but I never saw two chickadees come to blows. Of course, when young chickadees are hungry, they will cry for food just as any child. Not one of the seven was the least backward in coming forward when a morsel of food was in sight. Each honestly believed his turn was next. Once or twice I saw what looked like a family jar. Each one of the seven was crying for food as the mother flew over. She herself must have forgotten whose turn it was, for she hung beneath the perch a moment to think. How she ever told one from the other, so as to divide the meals evenly, I don't know. There was only one chick I could recognize, and that was pigeon-toed, tousled-headed Johnnie. He was the runt of the family, and spoiled, if ever a bird was spoiled.

We trudged up the cañon early the next morning. Four of the flock had left the nest and taken to the bushes. Three stayed at the stump while we set the camera. It is rarely indeed that one catches a real clear photograph of bird home life such as the mother placing a green cutworm in the mouth of a hungry chick; a satisfied look on the face of the second bantling who had just got a morsel; and hope on the face of the third who is sure to get the next mouthful: the present, the past, and the future in one scene.

There are perhaps many other families of chickadees that live and hunt through the trees along Fulton Creek. I rarely visit the place that $I$ do not hear them. But ever since the seven left the old alder stump that has now fallen to pieces, I never see a flock about this haunt that 
they do not greet me with the same song I heard three years ago, "Tsic-a-dee-dee! Seven-are-we!"

\section{THE CHICKADEE OR TITMOUSE FAMILY}

The Chickadee is one of our few winter residents; he is hardy, always cheerful, and braves the coldest winter spell. He is musical after his own fashion, always active and restless, heedless of man's presence. $\mathrm{He}$ is only five inches long with a black and white coat, and is generally seen hanging head down, hunting insect eggs and bugs under the limbs and leaves.

Chickadee (Parus atricapillus): Male and female, top of head and back of neck and throat, black; sides of head, white; back, ashy or grayish; under parts, whitish. Resident of eastern North America north of the Potomac, winter as well as summer. Nest, in a hole in a stump, made of wool, hair, and feathers. Eggs, six to nine, white speckled with brown.

Western Chickadee (Parus atricapillus occidentalis): Almost identical with above. Lives on the Pacific Coast from California to Alaska. 


\section{PHOTOGRAPHING FLICKERS}


. 


\section{III}

\section{PHOTOGRAPHING FLICKERS}

TF I were the owner of the firs about the reed-covered pond and were drawing rental from the bird tenants, I would rather take a lease from the Flickers (Colaptes cafer collaris) than any other feathered family. They're not always amoving south and leaving your trees without an occupant as soon as the frost nips. When the thermometer drops low and the kinglets are twittering too softly to be heard more than a few yards away, "highhole "always sends a full share of bird cheer up and down the scattering woods. Nor is he half as particular as some of the other bird residents. He takes the best of the few remaining stumps and seems satisfied. Once he pounded out a wooden home just below his last year's house. His wife didn't like it very much, but they settled it in some way and reared a thriving family.

One January day I was wading through the wet grass and low bushes near Ladd's farm when a flicker flapped up almost in my face. His mate followed. I found several holes where they had been driving into the ground for food. The bug supply under the bark was low, or maybe it was purely a voluntary change of diet.

"Red-hammer" of the West, like "yellow-hammer," his eastern cousin, is a rather odd mixture of woodpecker and robin. The Picus family in general takes its food 
from the bark of a tree, but red-hammer often feeds on berries, grain, and earthworms. According to woodpecker taste, a bird should cling to the side of a tree, clutching two toes above and two below, with body propped by his tail, but high-hole is independent, and often sits on a limb as an ordinary percher. Nature has given the flicker a bill slightly curved instead of straight and chisel-shaped. But why does this westerner parade the woods in a jaunty suit lined with red, while his eastern cousin flaunts from tree to tree in a yellow-lined jacket?

High-hole is somewhat of a barbarian among the Romans about the pond. He knows nothing about, nor does he care for, the finer arts of architecture and music. A dark den suits him as well as a mansion. He has a voice like the "holler" of a lusty-lunged, whole-souled ploughboy. As he swings from stump to stump his wings flash red like a beacon light. He shouts "Yar-up! Yar-up! Yar-up!" from the tree-top, or occasionally he breaks the woody silence with a prolonged jovial " $\mathrm{Ha}$ ! $\mathrm{Ha}$ ! $\mathrm{Ha}$ !"

There's always a sentiment of the farm about the flicker. Occasionally I see one of the birds here in the midst of the city, but he always reminds me of a backwoods boy on a visit. He never seems at home among the clanging of the cars and the rumbling of the wagons along the paved streets. A few days ago I saw one of these woodpeckers light on the side of a brick building above the busy street. I knew it was an inexperienced bird, for he began jabbing at the tin cornice in a way that seemed to me was likely to splinter his bill. It resounded like a drum. He cocked bis head with a surprised expres- 
sion that seemed to say, "That's the funniest tree I ever tapped." Then he flipped across the street and started a tattoo on a window-sill, but some one pushed up the window to see who was trying to get in and almost scared the youngster witless. The last I saw of him he was taking a bee-line straight across the block for the hills.

With a tinge of regret $I$ have watched the clumps of fir thinned year after year. High-hole does not care a snap. He can bore a hole in a church steeple as easily as in a fir snag. The moral influence on his family is about the same in one place as the other. For two seasons I watched a red-shafted flicker rear his family in the tall steeple of a Presbyterian Church in the heart of the city. I was always a little afraid lest the strait-laced divine discover the brood of squabbling youngsters sheltered under the sacred roof, seize a scourge, and drive them from the temple. They worked as hard on the Sabbath as any other day of the week. Another flicker dug a home in one of the maples that bordered the walk about a large grammar-school. The poor hen was harassed half to death by attention from the boys, but she reared four lusty shouters.

I have known high-hole for years. For two seasons we have photographed him and his family. He has punctured every old stump about the pond with doors and windows. Every one of these old boles is dead to the root, yet I generally find them throbbing at the heart more vitally than the greenest neighbor in the clump. Redhammer is not altogether idle during the months of rain and snow. When he does work, he goes like an automatic toy wound to the limit. As soon as the weather brightens 
into the first warm, springlike day, he and his wife have a wooden house well near its completion. Last spring when I first discovered the brand-new hole at the top of the stump, the lady of the house sidled around the tree like a bashful school-girl, always keeping on the opposite side and peeking around the curve.

Few birds have larger families than high-hole. But, were it not for the number of his family, how could he hold his own among so many enemies? His conspicuous size and color always draw the aim of the small boy's gun, and every village lad in the land has collected flicker's eggs. He is a fellow of resources, however. If his home is robbed, his wife soon lays another set of eggs. It is on record that one pair, when tested by the removal of egg after egg, laid seventy-one eggs in seventy-three days. In the hollowed heart of the punky fir on a bed of fine wood bits, lay seven glossy eggs, inanimate, but full of promise. They all had the vital flesh tinge of pink. Each imprisoned a precious spark of life to be fanned by the magic brooding of the mother's breast.

Red-hammer had grown quite trustful. We got a ladder twenty-five feet long which reached about up to the nest. The eggs had been placed a foot and a half below the round entrance. On the opposite side from the entrance and on a level with the eggs, we sawed out a back door, giving a good view of the living room and letting in a little sunlight. With the camera ready to snap, firmly fastened to a small board, we climbed the tree. Holding it out to a measured distance, we aimed it downward at the eggs. The first attempt came nearer landing camera and all in a heap in the shallow water of the pond than 


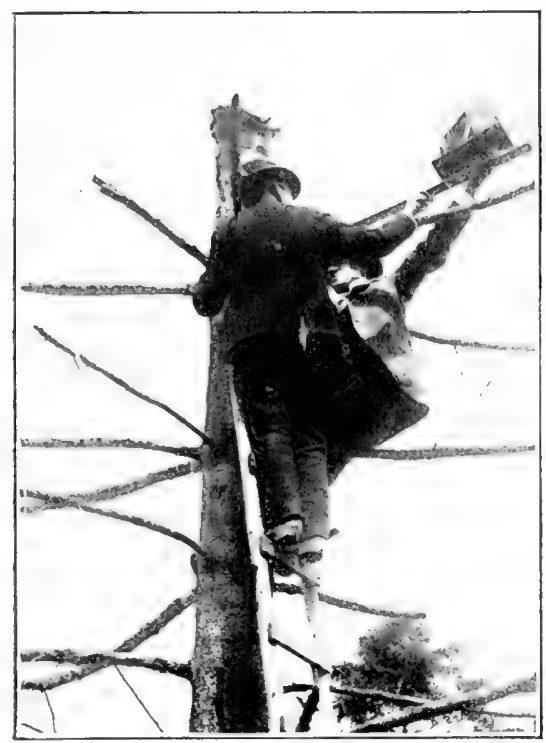

Photographing the Flickers' nest.

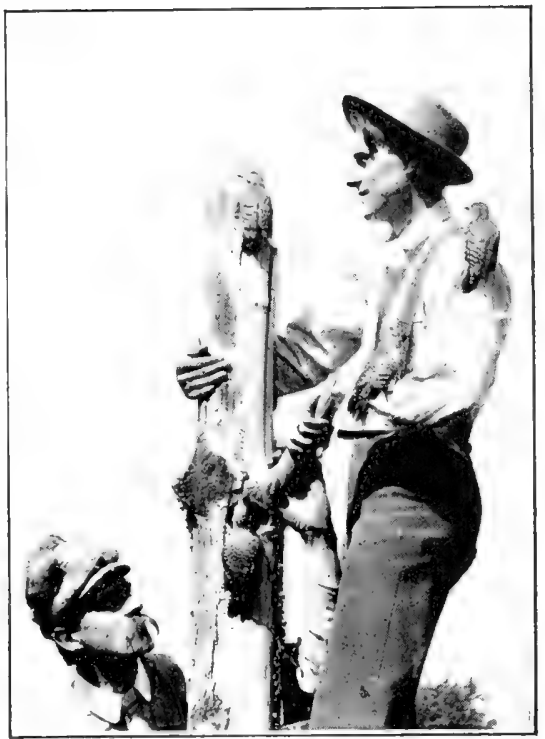

They liked to cling to un clothing.

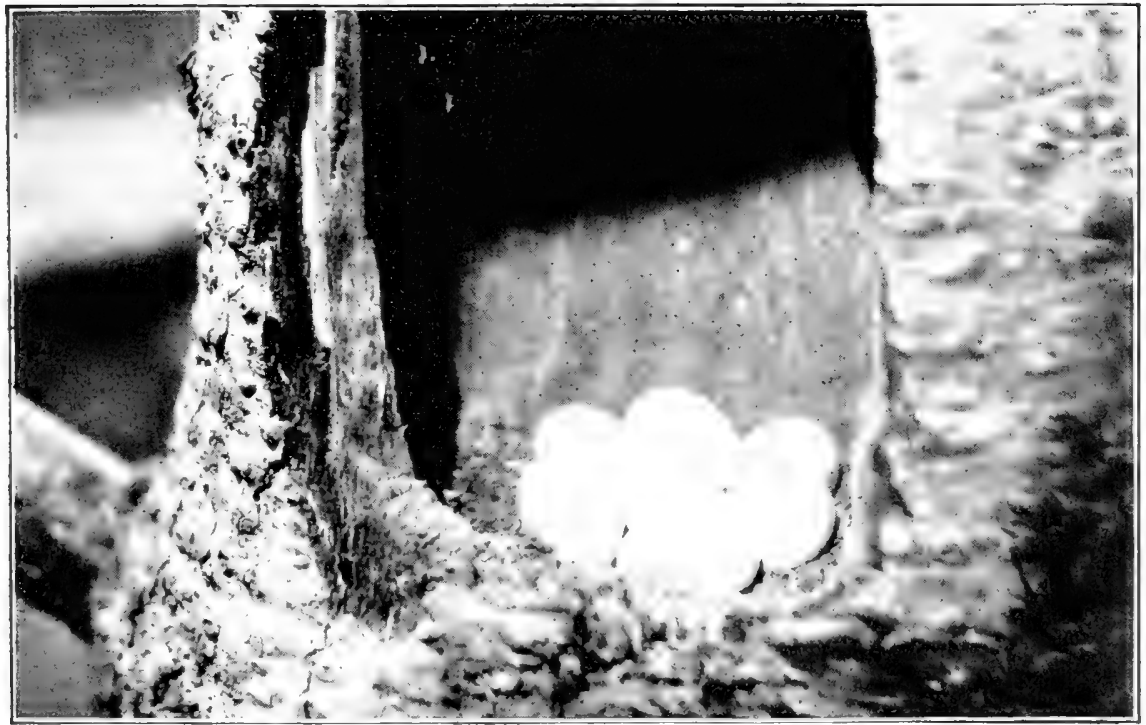

Nest and eggs of Flicker, with side of stump sawed out. 
. 
getting a photograph of the eggs, but after several trials a good picture was taken.

Neither mother nor father flicker seemed exactly to understand our right of making free with their home. The former nervously returned to her nest each time we descended the tree. She climbed in the front door. It was easy enough to recognize her own eggs, but that new door was a puzzle. She had to slip out and examine it half a dozen times, returning always by the round door above. The change made her a little uneasy, but she soon settled down, satisfied to brood and watch her gossiping neighbors at the same time. After we fastened up the new entrance, flicker affairs went on as usual.

Some of our later visits were certainly a little tiresome for the brooding mother. A knock at the foot of the tree was generally followed by an impatient eye and a dangerous-looking bill at the threshold-the greeting a busy housewife gives an intruding peddler. With a bored look she flipped across the way and sat while the visitors nosed about and prowled in her house.

Those naked baby flickers were the ugliest little bird youngsters I ever saw. High-hole did not carry their dinners in her bill, as a warbler feeds her young. She nourished the bantlings with the partially digested food of her own craw. She jabbed her long sharp beak down their throats till I thought she would stab them to death. Yet they liked it. They called for more with a peculiar hissing noise. A few feet away it sounded more like the buzz of maddened bees. I always feel like jumping to the ground and taking to the timber the instant that swarmy sound strikes my ear. It's not exactly cowardice, but bird 
curiosity once led me to pry into a hornet's nest in a hollow log. I've been a little skittish since. I am not sure of Nature's reason for providing woodpeckers with such a peculiar baby prattle, but I know the sound has scared more than one boy into shying away from a flicker's home. In the heart of the fir the growth was rapid. The thin drawn lids of each callow prisoner cracked and revealed a pair of black eyes. Feathers sprouted and spread from the rolls of fatty tissue up and down their backs. Each bill pointed ever upward to the light; the instant the doorway darkened, each sprung open to its limit. The nestlings soon took to climbing the walls, not solely for amusement. The sharp ears of each youngster caught the scrape of the mother's claws the instant she clutched the bark of the tree, and this sound always gave rise to a neck-stretching scramble toward the door. The young woodpeckers had little chance of exercising their wings. The next time we climbed the tree with the camera they were apparently full grown, strong in climbing, but, to our advantage, weak in flying.

We are not likely to forget the day we climbed the stump to picture the young flickers. The full meaning of the task had not struck us. Nor had the enjoyment of it dawned upon the fledglings. They were bashful at first, but after a little coaxing and fondling they were as tame as pet pussies. They climbed out and crowded the stumptop, where they sat in the warm sunshine stretching, fluffing, bowing, and preening.

They liked to cling to our clothing. A coat sleeve was casier climbing than a tree trunk, and it was softer to penctrate with a peck. There was a streak of ambition 
in the soul of each flicker that would put most people to shame. They climbed continually, and always toward the top. Up our arms to our shoulders they would go, and then to our heads. Just at the instant one's mind and energy were directed toward balancing in the tree-top, he was sure to get a series of jabs in the cheek. One might endure the scratch of the sharp claws as they penetrated his clothing, but he would be likely to cringe under the sting of a chisel-shaped drill boring with rapid blows into his arm.

I couldn't see any use in the parents working themselves to death feeding such ravenous, full-grown children. "They might as well hustle a little for themselves," I said, as I climbed the stump next morning. We took all five of the fledglings to the ground. Wild strawberries they gulped down with a decided relish, until we got tired and cut short the supply. We soon had a regular yaruping concert. One young cock clutched the bark with his claws, his stiff-pointed tail feathers propping his body in the natural woodpecker position, as he hitched nestward up the tree, followed by his mates.

Afterward when I set all five on a near-by limb with the order "Company, attention! Right dress!" they were the rawest and most unruly recruits $I$ ever handled. If the upper guide did not keep moving, he received a gouge from his impatient neighbor below. This was sure either to set the whole squad in motion, or to start a family brawl, without regard to the annoyance of the bird photographer. "About, face!" was executed with the same lack of discipline on the part of the feathered company. The captain stepped meekly around to the other 
side of the limb and planted himself and camera in the rear.

During our early acquaintance the fledgling flickers savagely resisted our attempts to coax them out of their home. After a few hours in the warm sunshine, they fought every effort to put them back. They were no longer nestlings, for a bit of confidence had turned them into full-fledged birds of the world.

The following day it was noticed that the flicker population of the fir woods had increased. Here and there one caught sight of a bird bearing the emblem of a black crescent hung about his neck. Juvenile yar-ups echoed among the scattered trees and over the pond. Occasionally there were flashes of red as wings opened and closed and a bird swung through the air in wavelike flight.

\section{THE WOODPECKER FAMILY}

The Woodpeckers are easily recognized because they habitually cling to the bark and climb straight up the limbs, pecking for eggs of insects and worms. The bill is strong and chisel-shaped; the tail feathers stiff and bristly. The woodpecker foot differs from that of other birds in that it has two toes behind and two in front.

Flicker (Colaptes auratus), Golden-winged Woodpecker, Yellowhammer, High-holder: Male, above, golden-brown, barred with black; white patch on rump; breast, with black crescent; below, brownish dotted with black; black patch on cheeks, red band on back of head; lining of wings and tail, yellow. Female lacks the black cheek patches. Lives in northern and eastern United States to Rocky Mountains, where it arrives from the South in April and stays till October. Nests generally in a hollow tree. Eggs, pure white, usually six to eight.

Red-shafted Flicker (Colaptes cafer collaris): Much the same as above, except wings and tail lined with red. Red instead of black cheek patches, and no red on back of head. Common on Pacific Coast. 


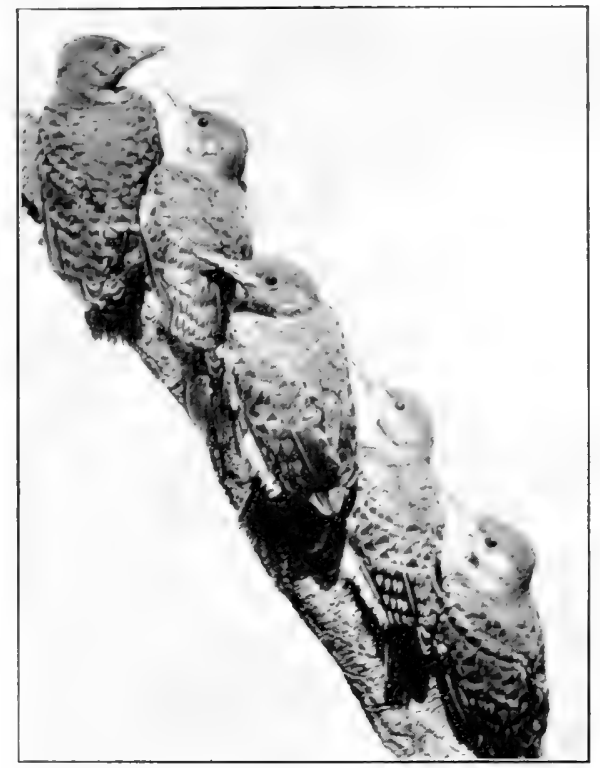

"About face!"

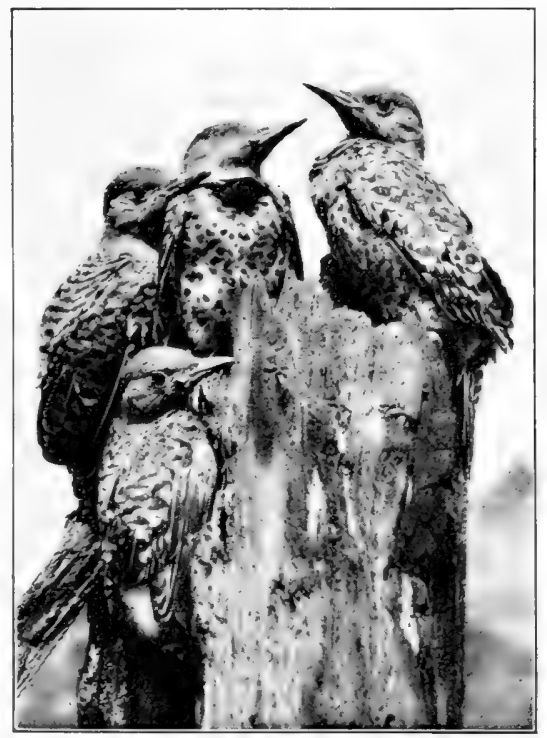

A family of young Flickers.

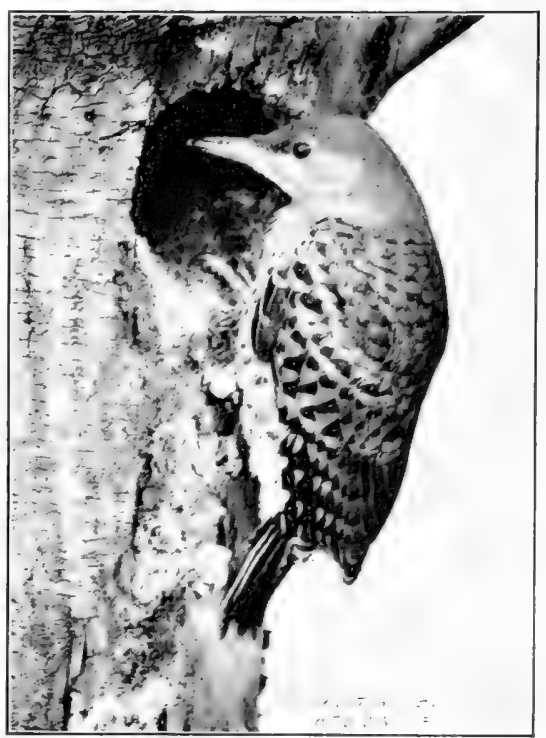

Flicker at the front door of her home. 

THE YELLOW-THROAT 
. 


\section{IV}

\section{THE YELLOW-THROAT}

$\int \begin{aligned} & \text { UST below the brow of Marquam Hill, half a mile } \\ & \text { above the creek, a little spring bubbles out of }\end{aligned}$ alder copse. Instead of trickling down the hillside like an ordinary streamlet, the water scatters and sinks into the spongy soil; it forms a wet place an acre or so in extent, over which has sprung up a rich growth of swamp grass. This is the Yellow-throat's (Geothlypis trichas occidentalis) home. I call it the witches' garden.

There's a fascination about lying in the shade of the alders on the brow of the hill. Overhead on the top branches of the maple, is the favorite perch of a meadow lark, who never fails to rear a brood of singers each season. He scatters his notes downward as the wind of autumn whirls the red and gold-tinted leaves. A flicker rattles his salute from the hollow top of a fir stump. A grosbeak trills a roundelay that fairly sparkles in the sunshine. But none of these charm me like the fanciful call of the yellow-throat. You may hear him almost any time of the day calling, "Witch-et-y! Witch-et-y! Witchet-y!" Yes, you may hear him, but seldom see him.

I never know just when yellow-throat will return in the spring or when he is going to depart in the fall. You may hear him one day and find your garden tenantless the following. Then, after a long silence, you wake up some 
morning and find he's there again, as if he had grown out of the ground during the night, like a toadstool. After his return, he soon begins to scratch out a hollow in a tussock of swamp grass.

What a little deceiver this golden sprite is! Looking for his nest is something like searching for the bags of gold at the rainbow's tip. If you stand under the alders, looking down over the garden, he will call, "Here-it-is! Here-it-is! Here!" and a minute later he will shriek the same lie from another tussock ten yards away.

It seems to be the appointed duty of this little witch to sing his lies all day long, while his wife broods the eggs. He wears a jet-black mask across his face. Perhaps when Nature gave out the bird clothes, she gave this to him just so he could sing his falsehoods without a blush. The lady hops about without the sign of a veil, while the gentleman always wears a mask; it's the Turkish custom reversed.

While I was honest and open in my treatment of yellow-throat, he simply met every advance with deceit. I tried to visit his house again and again when Mrs. Yellowthroat was at home, but every time he led me by a different path to the furthest limits of the garden. I tried to take him unawares, but he seemed to do nothing else except come out to meet visitors and pilot them in the wrong direction. Whenever I got too near the home the wife herself slipped off the nest and appeared right before me calling, "Here-I-am! Fol-low-me! Fol-low!"

At last I tried cunning. I took a long rope, and two of us crept up to the edge of the garden late one afternoon. We quietly spread out, each taking an end of the 


\section{The Yellow-throat}

cord. At a signal we skirted the opposite sides of the garden on a dead run, brushing the grass tops with the rope. Just as it switched across the lower end a yellow streak flashed in the air like a rocket, and as quickly disappeared. She never dreamed of a snake sweeping the grass tops at such a lightning speed as that rope went. It scared her witless. I walked over and saw her nest and four eggs set down in the middle of a thick tussock.

At last I had the little deceivers in my power. They found me not such a cruel tyrant after all. They had played me long, but now the game was mine, and the minute they lost, they gave up deceitful methods. Day after day the wife kept her vigil of love upon the spotted eggs.

We laid siege with the camera, but not in a way the least obtrusive. A service-berry bush grew a few feet away, which was a favorite perch of both parents. We soon had a rampart of limbs built, from behind which the camera was levelled at the bush. After covering everything with green, and attaching a long hose and bulb to the shutter, we were ready. The mother was on the nest most of the time, but the father stayed about near at hand and kept flitting back and forth, like a watchman on his round. Catching his picture was just like waiting for a bite on a lazy day at the river. But it was a good deal more exciting when the fidgety father lit in the servicebush.

It takes patience to catch bird photographs. Patience is the salt of the old bird-catching legend. You may have to wait hours at a time. Often a whole day slips by without getting a single good picture, but if you have had your 
eyes open, you have not failed to pick up some interesting bits of information.

Hunting and fishing have their moments of intense excitement. Occasionally I like to go back to the more primitive way by taking to the trail for two or three weeks to hunt and fish for a living. It sharpens the senses to live as the Indian lived. I have waded mountain streams and whipped the riffles for trout. I have hunted the woods for a dinner of grouse and quail. There's not a moment of more intense excitement that comes to the fisher or hunter than comes to the photographer as he lies hidden in the bushes, camera focused and bulb in hand, waiting for some sly creature to come into position. If it takes a fine shot to clip the wing of a flying quail, or to catch a buck on the jump, it takes a skilled hand to anticipate bird movements that are too rapid for the eye, and click the shutter at the exact instant. A smile of deep satisfaction sweeps over the face of the photographer as he stands over the dim, red-lighted bench and sees the magic chemicals transform the white-colored glass, and etch out a feathered family as true as life itself. He has a feeling of higher pleasure than the hunter gets in looking at his game.

Yellow-throat, according to my ideas, was more of an ideal husband and father than many male birds. He was thoughtful about the home, he worked side by side with his wife, and never failed or faltered for an instant. In fact, he often marched squarely up in the face of the camera, when his mate had some doubt about facing the stare of the big round eye. By this time he had forgotten his witchety call. $\mathrm{He}$ crossed the border of the garden 


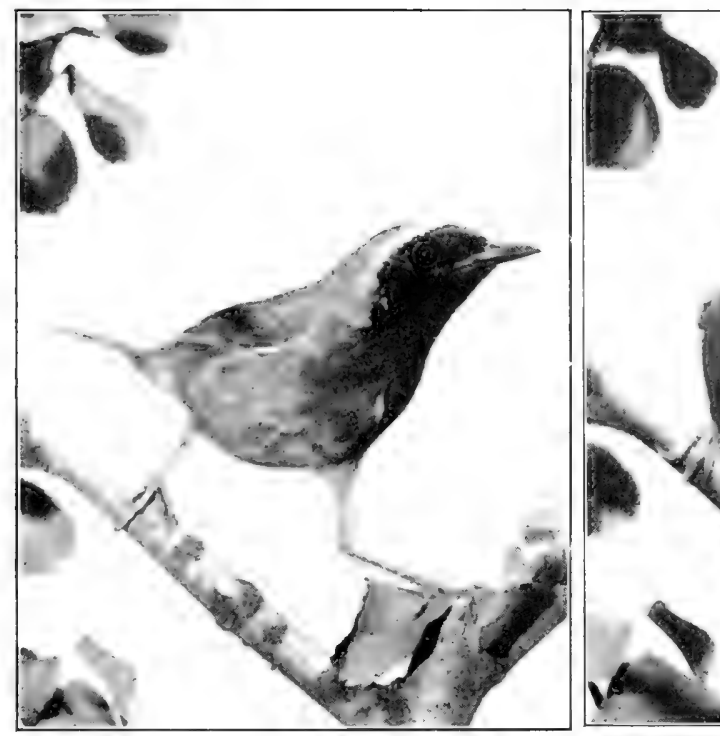

Male Velluw-that
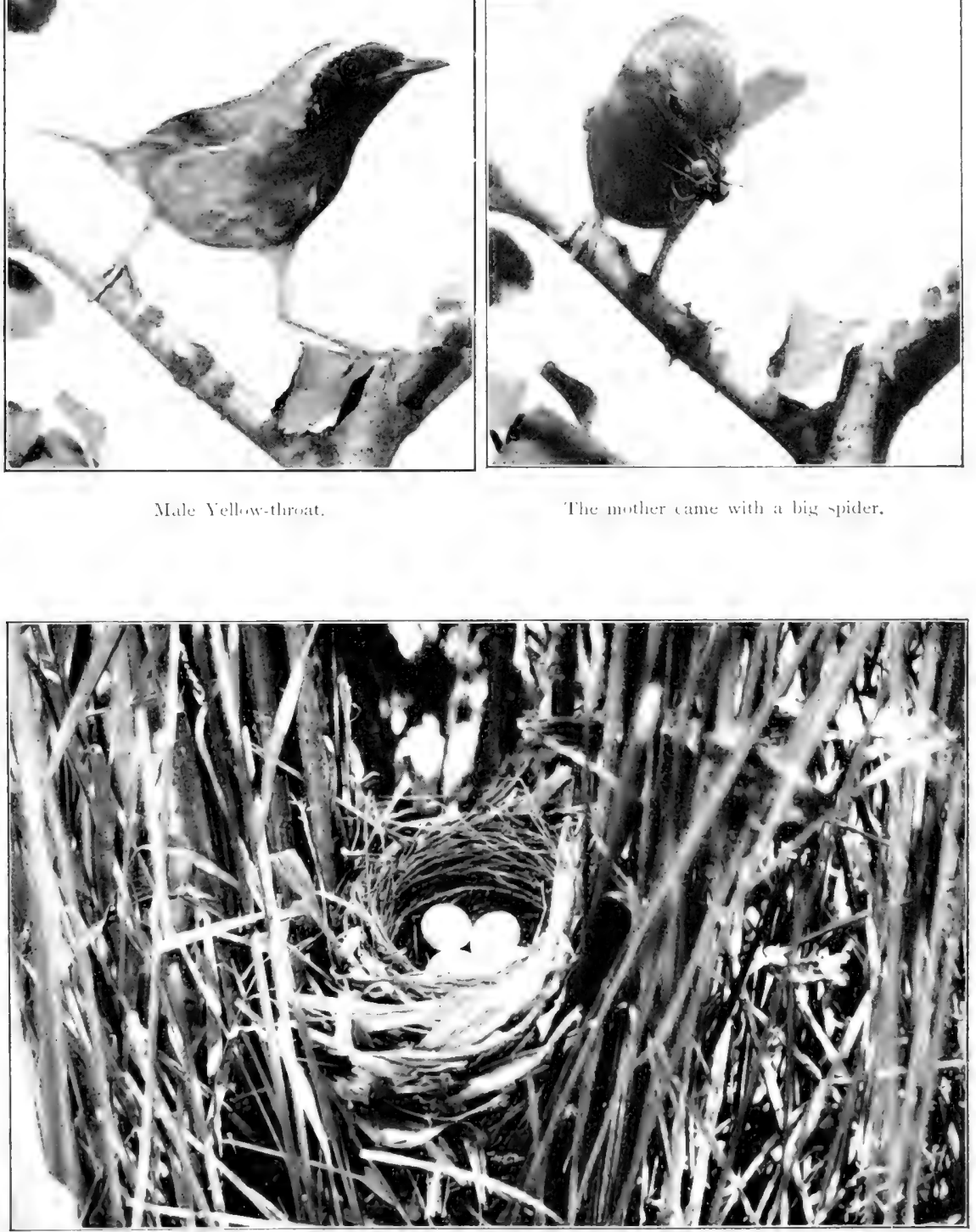


\section{The Yellow-throat}

with a harsher note of authority, "T'see-here!" $\mathrm{He}$ dropped to a quieter, "Quit! Quit!" when he approached the nest, as if he were afraid of waking the babies.

One day when I spent all afternoon about the nest, my note-book read as follows: "Two of the youngsters were out of the nest. Set up a perch for them, focused the camera at one o'clock, and hid in the bushes. In five minutes the mother came with a big spider, which she held carefully, so as not to puncture the body and lose the substance. The father was right at her heels. Both fed and went away on a hunt together inside of two minutes. They returned in five minutes with green cutworms. While the mother was feeding one of the bantlings, he fluttered with such delight that he fell from the perch in trying to swallow his morsel. Both parents stayed about watching the young for ten minutes. After they departed, the mother returned in three minutes, but had no food. She hopped about the limbs over my head, watching her children with an anxious eye, till she heard the call of her mate, when she left. Inside of eight minutes they were both back again with caterpillars and a moth. The mother fed, but the father hopped about the bush a moment or so and swallowed the mouthful he had, wiping his bill across the $\operatorname{limb}$ with a satisfied air. In four minutes the father was there again with a fat grub, which he gave to one of the children. It was such a huge mouthful that it took a little push to start it down. He hopped up on the camera, stretched his wings, and preened himself till he heard his wife."

The next day as I sat in the shade watching the two 
bantlings, I had to roll over in laughter at their actions. Each youngster was afraid his brother would get the next morsel, and his fears were quite often realized. Two or three times they became so excited that they went at each other as if it were going to be a case of "may the best man win." I don't believe in brothers quarrelling, but once or twice, while I was watching, I saw just cause for disagreement. Both mother and father were putting their whole energy to satisfying the two little stomachs that seemed to go empty as fast as they were filled. The two bairns were sitting side by side, when the mother dropped to the perch, and gave the nearer one a big caterpillar. The father came two minutes later. If he tried to tell who had the last bite by looking at those wide-stretched mouths, he was fooled. In a twinkling the chick had taken the morsel he brought. "That belongs to me," yelled the brother in righteous indignation, but it was too late, papa was gone; so he squatted down beside his squirming brother with a stoical expression that showed it was better to be a little too empty than a bit too full.

Both parents seemed nervous when their children were out in the unprotected open. They always tried to coax the little ones down into the bushes before giving them food. I happened to discover a very urgent reason just why these yellow-throats had to keep under cover. My camera was well concealed and aimed at a branch where the two bantlings were perched, while I was hidden a few feet away, waiting to click the shutter on one of the parents when they came to feed. By the merest chance I happened to look around, and saw a black object whizzing earthward like a falling star. Instinctively I jumped up. 


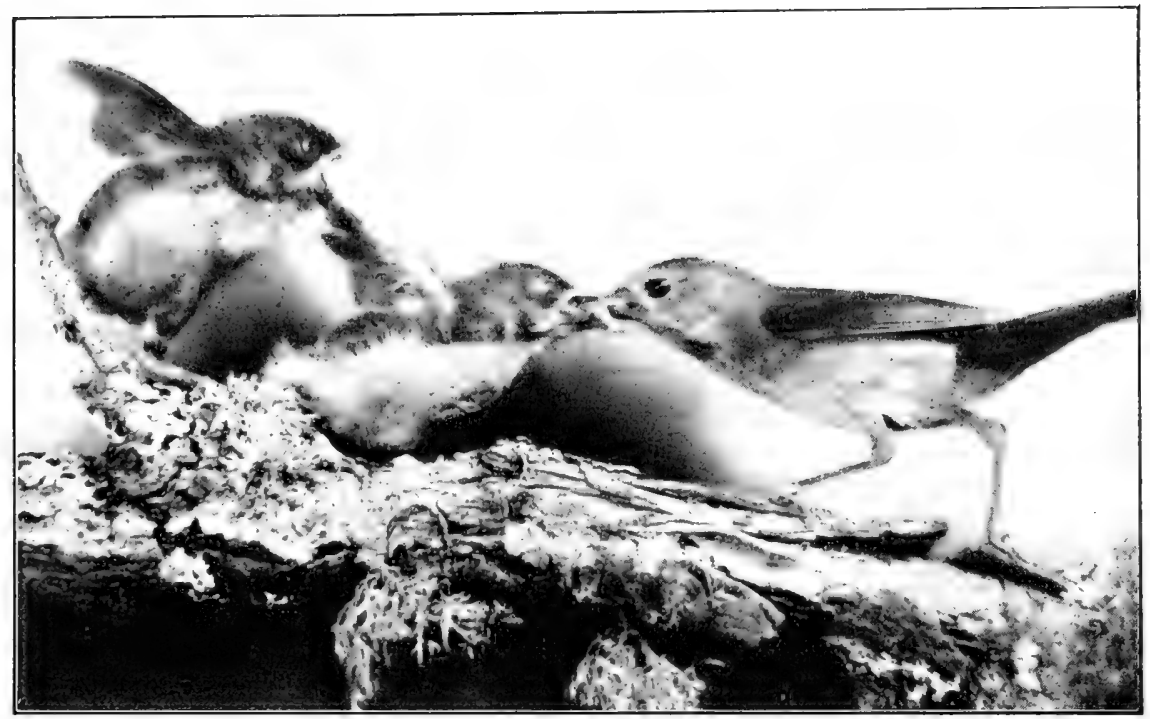

The mother dropped to the perch, and gave the nearer one a big caterpillar.

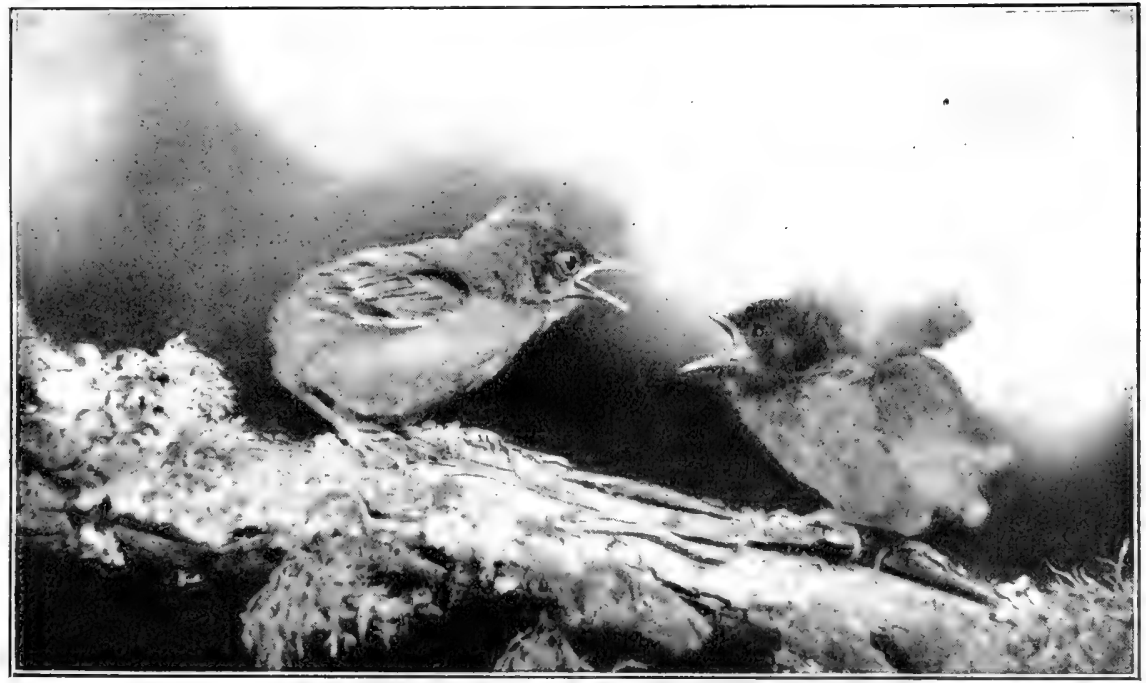

Young Yellow-throats quarreling. 
It swerved at the very point of striking, and glanced upward with a swishing sound, and left me gazing at a Cooper hawk that sailed off down the hillside. Later I discovered what the yellow-throats had known all the time that this hunter had a nest in a fir half a mile down the cañon, and that this very garden was part of his hunting preserve.

The yellow-throats grew in strength, and later set out with their parents for the southland. I may never see the children again, and I would hardly know them if I did, but I am sure the parents will build a new summer cottage in the garden as soon as winter goes away.

\section{THE GROUND WARBLER FAMILY}

This is a part of the Wood Warbler family, but these birds differ in that they stay habitually in bushes or among the grass. The nest is generally placed on the ground.

Maryland Yellow-throat (Geothlypis trichas): Male, top of head, olive-gray gradually changing to bright olive on rump; under parts, under wing and tail feathers, rich yellow, fading to white on the belly; forehead and sides of head masked with black, separated by ash-white line from crown. Female, smaller and colors less distinct; no black mask on head. Summer resident of eastern United States, arriving from the South during the first week in May. Nest placed on the ground or in a bushy tangle.

Western Yellow-throat (Geothlypis trichas occidentalis): Like the above, but slightly larger owing to longer tail. Nesting habits same as above. Inhabits western United States, arriving from the South about the second week in April.

Mourning Warbler (Geothlypis philadelpbia): Male and female, head, throat, and breast dark slate or gray, making the bird appear as if wearing crape; back, olive-green; clear yellow below. In the West, this bird is named Macgillivray Warbler. 

A FAMILY OF GROSBEAKS 



\section{V \\ A FAMILY OF GROSBEAKS}

NE day I crossed the road below the yellow-throat's garden, broke through the thick fringe of maples and syringa brush, and crawled along on my hands and knees under the canopy of tall ferns. The ground was soft and loamy. The dogwood saplings, the hazel and arrowwood bushes grew so thick that each vied with the other in stretching up to reach the life-giving light of the sun's rays. Underneath, the blackberry reached out its long, slender fingers and clutched the tallest ferns to hang its berries where they might catch a glint of the sun, for the beams sifted through only in places. I was in the thicket of the Grosbeak (Zamelodia milunocephala).

For scveral years we have watched a pair of grosbeaks that spend their summers on the side hill in this clump. The same pair, no doubt, has returned to the thicket for at least three or four years. It secms I can almost recognize the notes of their song. If our ears were only tuned to the music of the birds, could we not recognize them as individuals, as we recognize our old friends?

In the grosbeak family, the cardinal or red-bird, is perhaps more familiar to us, since he is often seen behind the bars of a cage. But his colors fade in confinement, and he is no longer the brilliant bird of the wild that seems to have strayed up from the tropics. But even if the 
beauty of this bird should not survive, we have two other grosbeaks, the rose-breasted of the eastern states and the black-headed of the West, both alike in character and in habits.

The black-headed grosbeak is one of the birds of my childhood. As long ago as I can remember, I watched for him in the mulberry trees and about the elderberry bushes when the fruit was ripe. I could tell him from the other birds by his high-keyed call-note long before I knew his name. One day when I stopped to look for a bird that was carolling in one of the maples along the creek, I saw the grosbeak mother singing her lullaby, as she sat on her eggs. It looked to me so like a human mother's love. Few, if any other birds, sing in the home; perhaps they often long to but are afraid. As John Burroughs says, it is a very rare occurrence for a bird to sing on its nest, but several times I have heard the grosbeak do it. How it came to be a custom of the grosbeak I do not know, for birds are, in general, very shy about appearing near the nest or attracting attention to it.

Last year I found three spotted eggs in a nest loosely built among the leaves of the dogwood limbs. When I had seen the father carrying a stick in his mouth, he dropped it and looked as uneasy as a boy who had just been caught with his pockets full of stolen apples. This year the nest was twenty feet down the hill from the old home. They came nearer the ground and placed the thin framework of their nest between the two upright forks of an arrow-wood bush. We had never bothered them very much with the camera, but when they put their home right down within four and a half feet of the ground, it 


\section{A Family of Grosbeaks}

looked to me as if they wanted their pictures taken. It was too good a chance for us to miss. The ferns grew almost as high as the nest, and it was a fine place to hide the camera so as to focus it on the home.

When I waded through the ferns and pushed aside the bushes, the nest was brimful. Above the rim, I could see the tiny plumes of white down wavering in a breath of air that I couldn't feel. I stole up and looked in. The three bantlings were sound asleep. Neither parent happened to be near, so I crawled back and hid well down in the bushes twelve feet away. The father came in as silently as a shadow and rested on the nest edge. He was dressed like a prince, with a jet-black hat, black wings crossed with bars of white, and the rich, red-brown of his vest shading into lemon-yellow toward his tail. He crammed something in each wide-opened mouth, stretched at the end of a wiggling, quivering neck. The mother followed without a word and sat looking about. She treated each bobbing head in the same way. Then, with head cocked on the side, she examined each baby, turning him gently with her bill, and looked carefully to the needs of all three before departing.

The male stayed near the nest. When I arose and stood beside the arrow-wood he was scared. "Quit! Quit!" he cried, in a high, frightened tone, and when I didn't he let out a screech of alarm that brought his wife in a hurry. Any one would have thought I was thirsting for the lifeblood of those nestlings. She was followed by a pair of robins, a yellow warbler and a flycatcher, all anxious to take a hand in the owl-ousting if, indeed, an owl was near. I have often noticed that all the feathered neigh- 
bors of a locality will flock at such a cry of alarm. The robins are always the loudest and noisiest in their threats, and are the first to respond to a bird emergency call.

The weather was warm and it seemed to me the young grosbeaks grew almost fast enough to rival a toadstool. Sunshine makes a big difference. These little fellows got plenty to eat, and were where the sun filtered through the leaves and kept them warm. The young thrushes across the gully were in a dark spot. They got as much food, but they rarely got a glint of the sun. They didn't grow as much in a week as the grosbeak babies did in three days.

I loved to sit and watch the brilliant father. He perched at the very top of the fir and stretched his wings till you could see their lemon lining. He preened his black tail to show the hidden spots of white. Of course, he knew his clothes were made for show. It was the song of motion just to see him drop from the fir to the bushes below. What roundelays he whistled: "Whit-te-o! Whitte-o! Reet!" Early in the morning he showed the quality of his singing. Later in the day it often lost finish. The tones sounded hard to get out or as if he were practising; just running over the notes of an air that hung dim in his memory. But it was pleasing to hear him practise; the atmosphere was too lazy for perfect execution. He knew he could pipe a tune to catch the ear, but he had to sit on the tree-top, as if he were afraid some one would catch the secret of his art if he sang lower down. Perhaps he was vain, but I have watched him when he seemed to whistle as unconsciously as I breathed.

The morning of July 6th the three young birds left 



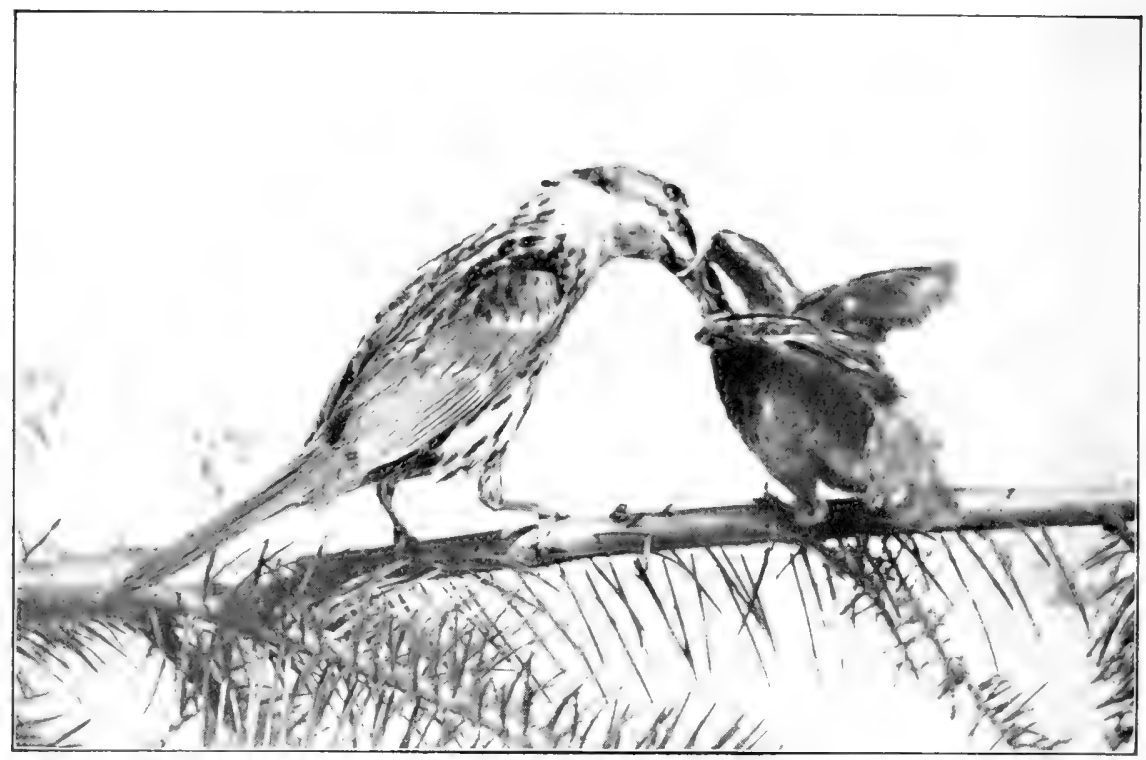

Mother Grosbeak feeding young.

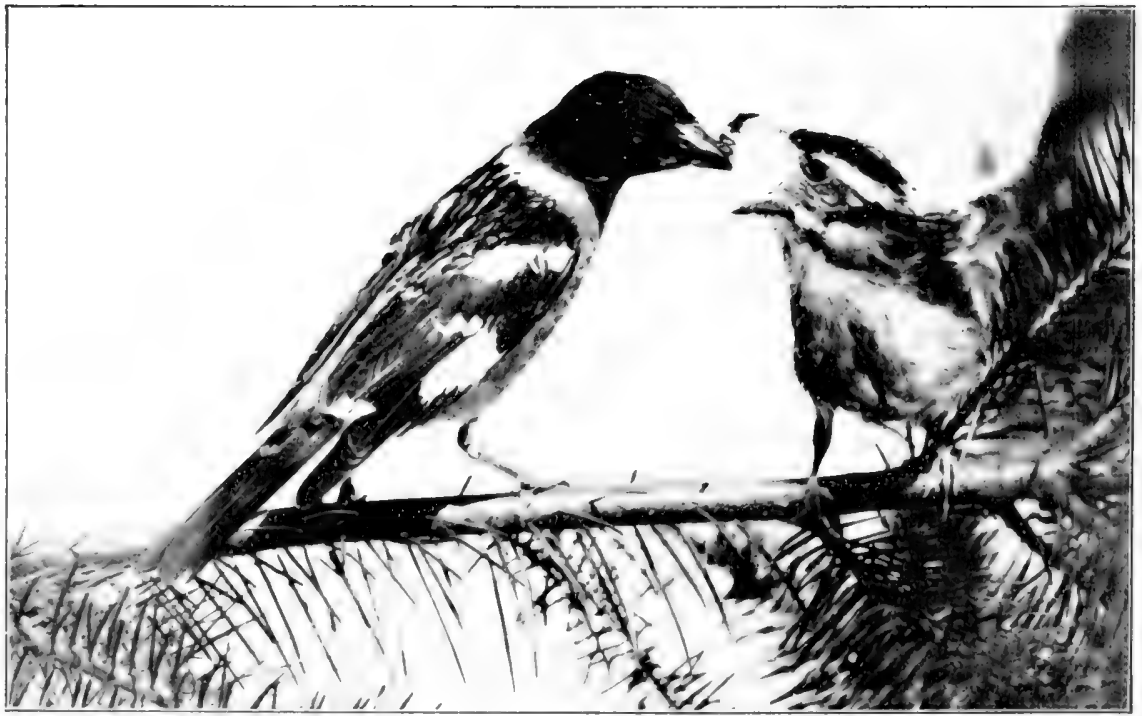

Male Grusbeak feeding young. 


\section{A Family of Grosbeaks}

the nest, following their parents out into the limbs of the arrow-wood. They were not able to fly more than a few feet, but they knew how to perch and call for food. I never heard a more enticing dinner-song, such a sweet, musical " tour-a-lee."

The triplets were slightly different in size and strength. The eldest knew the note of alarm, and two or three times when he got real hungry I heard him utter a shriek that brought papa and mamma in a hurry to get there before he was clear dead. Then he flapped his wings and teased for a morsel. The minute his appetite was satisfied he always took a nap. There was no worry on his mind as to where the next bite was coming from. He just contracted into a fluffy ball, and he didn't pause a second on the border-land; it was so simple; his lids closed and it was done. He slept soundly, too, for I patted his feathers and he didn't wake. But at the flutter of wings he awoke as suddenly as he dropped asleep.

The parents fed their bantlings as much on berries as on worms and insects. Once I sarv the father distribute a whole mouthful of green measuring-worms. The next time he had visited a garden down the hillside, for he brought one raspberry in his bill and coughed up three more. Both parents soon got over their mad anxiety every time I looked at their birdlings. In fact, they soon seemed willing enough for me to share the bits from my own lunch, for the youngsters were very fond of pieces of cherry taken from a small stick, twirled in the air above them.

We spent the next two days watching and photographing, but it took all the third forenoon to find the three 
bantlings. The mother had enticed one down the slope to the hazel bush near the creek. I watched her for two hours before I heard the soft tour-a-lee of the youngster. He perched on my finger and I brought him back to the nest. Another we found down in the thimbleberry bushes, which, with the third up in the maple sapling over the nest, seemed to be in the keeping of the father.

Nature has given the grosbeak a large and powerful bill to crack seeds and hard kernels, but it seemed to me this would be rather an inconvenience when it came to feeding children. If it was, the parents did not show it. The mother always cocked her head to one side so that her baby could easily grasp the morsel, and it was all so quickly done that only the camera's eye could catch the way she did it. She slipped her bill clear into the youngster's mouth, and he took the bite as hurriedly as if he were afraid the mother would change her mind and give it to the next baby.

After watching the grosbeak family all day, we put the children in a little isolated clump of bushes, late in the afternoon, and when we paid our visit early the next morning they were still there, but perched well up in the top limbs. We had at last reached almost a "bird-in-thehand "acquaintance with the parents. We could watch them at close range and they didn't seem to care a snap. The mother wore a plain-colored dress in comparison with her husband's almost gaudy suit. When he turned his head he showed a black silk hat that was enough to distinguish any bird, but I, for my part, would hardly have called his wife Mrs. Black-headed Grosbeak had I not known they were married. 


\section{A Family of Grosbeaks}

I have watched a good many bird families, but I never saw the work divided as it seemed to be in the grosbeak household. The first day I stayed about the nest I noticed that the father was feeding the children almost entirely, and whenever he brought a mouthful he hardly knew which one to feed first. The mother fed about once an hour, while he fed every ten or fifteen minutes. This seemed rather contrary to my understanding of bird ways. Generally the male is wilder than his wife and she has to take the responsibility of the home. The next day I watched at the nest conditions were the same, but I was surprised to see that the parental duties were just reversed. The mother was going and coming continually with food, while the father sat about in the tree-tops, sang and preened his feathers leisurely, only taking the trouble to hunt up one mouthful for his bairns to every sixth or seventh the mother brought. To my surprise the third day I found the father was the busy bird again. Out of eighteen plates exposed that day on the grosbeak family I got only five snaps at the mother, and three of these were poor ones. The fourth day I watched, the mother seemed to have charge of the feeding again, but she spent most of her time trying to coax the bantlings to follow her off into the bushes. It was hardly the father's day for getting the meals, but, on the whole, he fed almost as much as the mother, otherwise the youngsters would not have received their daily allowance. I have watched at some nests where the young were cared for almost entirely by the mother, and I have seen others where those duties were taken up largely by the father. Many times I have seen both parents work side by side in rearing a family, but 
the grosbeak seemed to have a way of dividing duties equally and alternating with days of rest and labor.

The grosbeak family stayed about the thicket for over two weeks. I saw the babies when they were almost fullgrown birds and watched them follow their parents about. They were able to find bugs and feed themselves, but each child knew it was easier to be fed than to go about looking under every twig and leaf. One juvenile flew up to the limb beside his father, quivering his wings and begging for a bite. His father straightened back and looked at him with an air of inquiry, "Why don't you hunt for yourself?" The little fellow turned his back as if in shame, but he kept on crying. The father flew into the next tree; the little beggar followed and squatted right beside him as if he half expected a trouncing. I looked to see him get it. The father turned and fed him. He couldn't resist. In some ways children are the same, and bird papas are, perhaps, a good deal like human papas.

\section{THE GROSBEAK FAMILY}

The Grosbeak is a seed-eater and is related to the sparrow family. It is about eight inches in length and has the build of a sparrow, but it is an abnormal sparrow, because of its immensely thickened bill. The Grosbeak is a good singer, with a finely colored dress.

Rose-breasted Grosbeak (Zamelodia ludoviciana): Male, head and upper parts, black, except for white rump and white markings on wings and tail; breast and under wings, rosy red; bill, white. Female, brownish color, no rosy tint on breast; yellow under wings; heavy brown bill. Found in eastern United States and southern Canada, from the first of May till the middle of September. Nest in bushes and low trees, thin and saucer-shaped, made of wiry roots. Eggs, from three to five, dull green with dark brown spots and specks. 


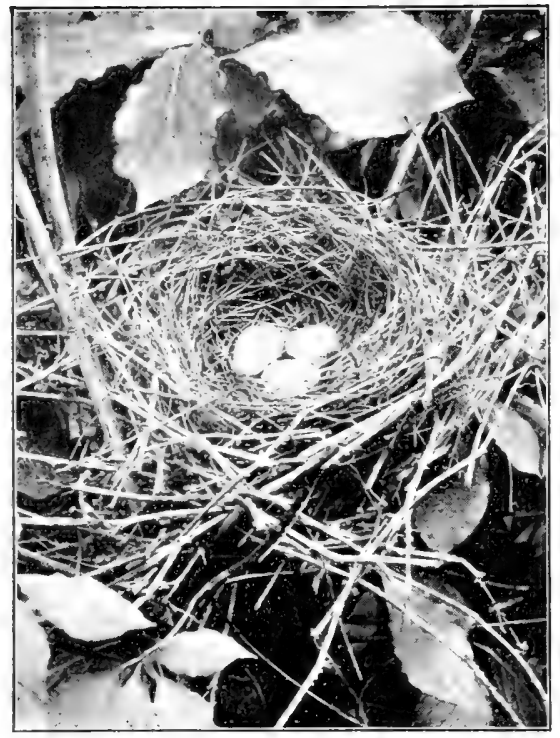

Nest and eggs of Hlack-headed (irosbeak.

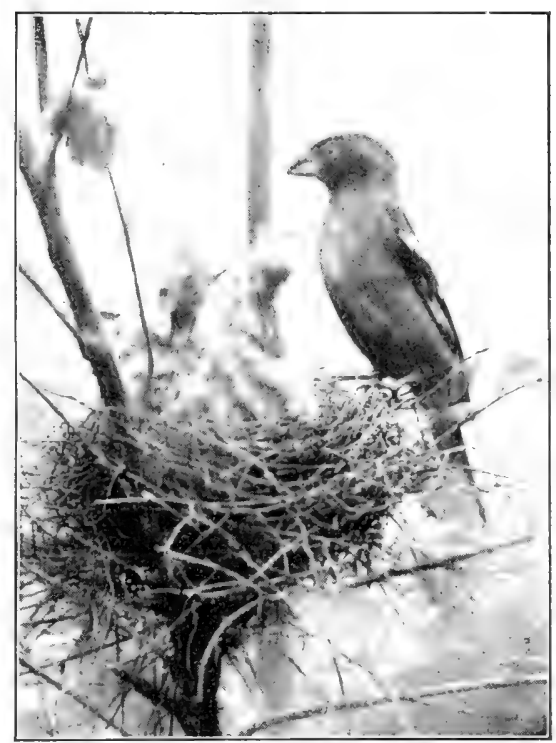

Male Cirosbeak at nest.

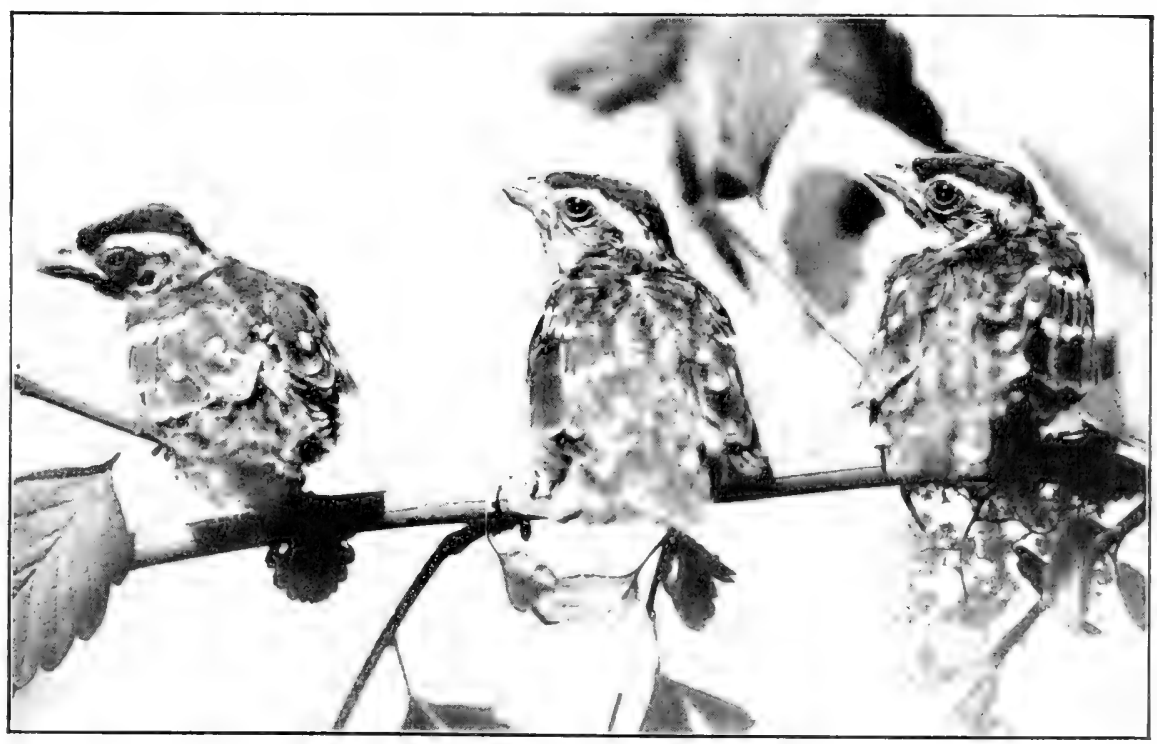





\section{A Family of Grosbeaks}

Black-headed Grosbeak (Zamelodia melanocepbala): Male, upper parts black with brown collar and brown on rump; two white wingbars; throat and under parts, rich orange-brown, changing to lemonyellow on belly and under wings. Female, plain brown color, sides streaked; collar and wing-bars, dull white; yellowish on belly and under wings. Inhabits western United States. Nest and eggs similar to Rose-breasted Grosbeak. 

THE RED-TAILED HAWK 



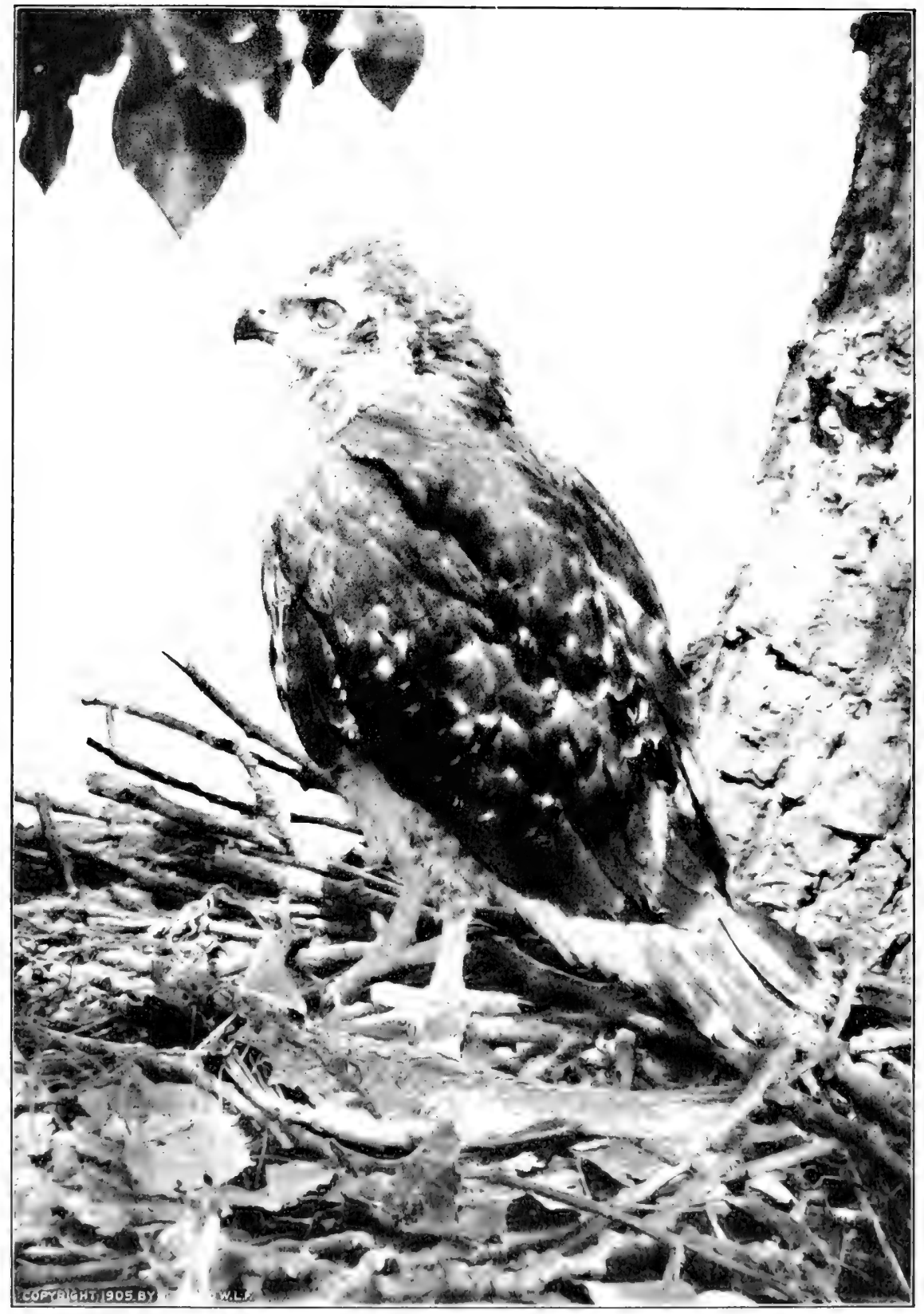

A full-grown young Red-tail. 


\section{VI \\ THE RED-TAILED HAWK}

THAT chicken-hawk's got a nest somewhere down in

1 them cottonwoods; he's been round there every year nigh as long as I can remember. He's never pestered any of my chickens, so I don't pester him," replied the old farmer, who had taken us out behind the barn to a little knoll where we could see the grove of cottonwood trees and the old hawk circling above them.

This was in the summer of 1898 while we were passing up the south bank of the Columbia River on a hunting trip. We searched the woods at the time but were unable to find the aerie. A year later we happened to be in that vicinity early in the springtime before the trees had leaved out and made a careful search for the hawk's nest. It was near the top of one of the tallest trees, and one look sufficed to give us both the same opinion: the nest was beyond human reach.

The Red-tailed Hawk (Buteo borealis) is perhaps the best known of the larger birds of prey throughout the United States. It may be found in almost every state where the woods still remain thick enough for it to find a good nesting place. The Pacific Coast is a better place for hawks and eagles than many of the eastern states. The tall trees, the sheer cliffs along the waterways, and the steep hillsides overlooking the valleys beneath, fur- 
nish ideal homes for these birds of prey. Their chosen sites are out-of-the-way positions where they are safe from human interference. The red-tail is perhaps commonest about the hills and in the valleys of California, where it builds in the scattered oaks. Almost every little cañon along the central coast region is occupied by a pair of these birds. Their nests are easily found in the early spring by scanning the trees for a mile up the hillside with a field-glass. The abundance of these hawks is due to the large supply of natural food they find about these regions. Squirrels, moles, and other rodents are very plentiful, and the hawks help to keep in check these pests that are such enemies to the farmer. If it were not for the birds of prey, the balance of nature would surely swing very much against those who till the soil.

A red-tail likes a high, commanding site for a nest, just as a mallard searches the sedge grass about a pond for a home, and the pair of hawks in the cottonwood had surely found it. We schemed for three different summers, after we found this aerie of the red-tail, before we finally succeeded in levelling our camera at the eggs. The nest tree measured over fourteen feet around at the bottom. There was not a limb for forty feet. The nest itself was lodged just one hundred and twenty feet up. It was out of the question to clamber up such a tree with climbers, ropes, or anything else, but we had another plan.

We had spotted a young cottonwood just fifteen feet away. This might serve as a ladder, so we chopped at the base till it began to totter. With ropes we pulled it over. The crown lodged in the branches of the first large limb of the nesting tree, full forty feet up. This formed 


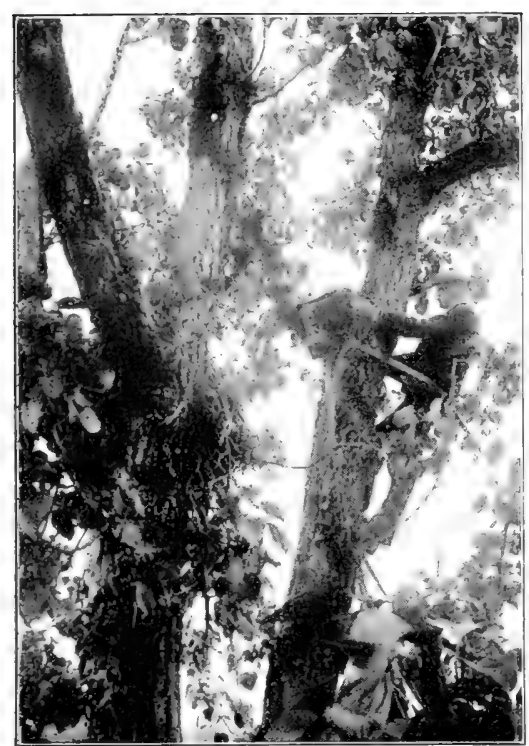

Taking pictures at the aerie of the Red-tail.

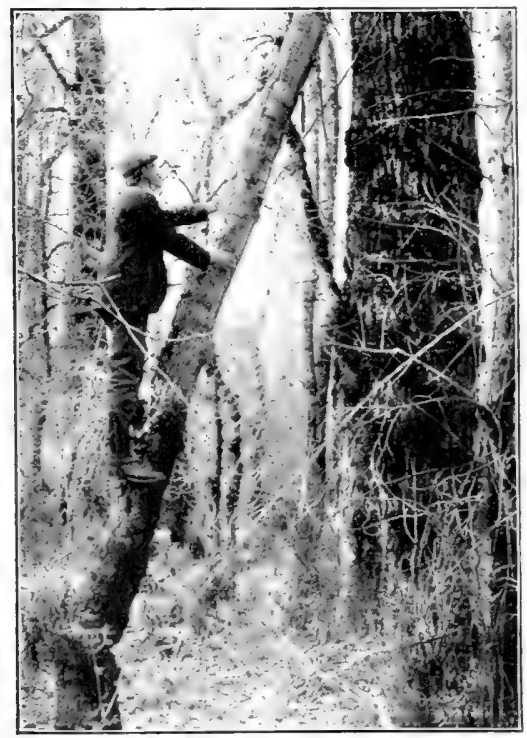

At the foot of the Hawk's tree.

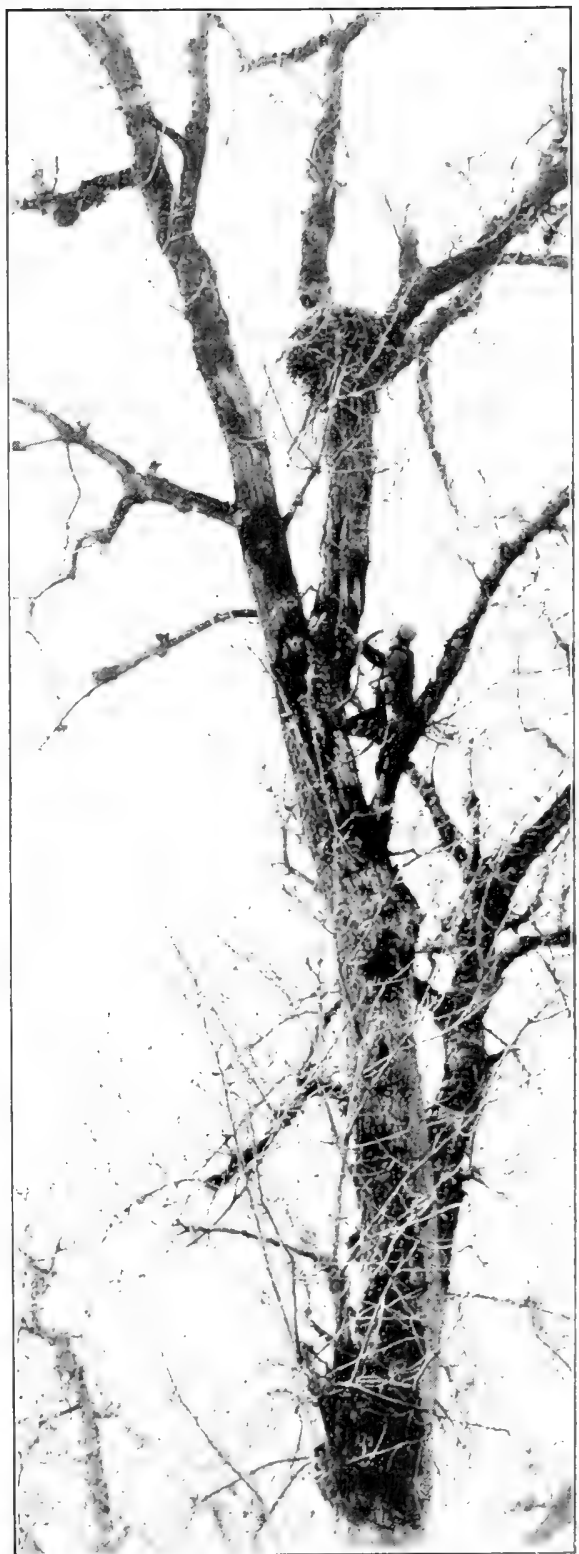

Aerie of the Red-tail in the tall cottonwood. 



\section{The Red-tailed Hawk}

a shaky bridge, up which we clambered a third of the way to the nest. Hope led us on. We lassoed upper branches, dug our climbing-irons into the bark and worked slowly up.

We found a stack of sticks the size of a small haycock. They were not pitched together helter-skelter. A big nest like a hawk's or heron's always gives me the impression that it is easily thrown together. I examined this one and found it as carefully woven as a wicker basket. It was strong at every point. Sticks over a yard in length and some as big as your wrist, were all worked into a compact mass. In the hollowed top, on some bark and leaves, lay the two eggs.

I never saw a more commanding stronghold. It overlooked the country for miles in every direction. From where the hawk mother brooded her eggs I looked out far up the Columbia, and I could see the cavern-cut slopes of Mount Hood. Extending to the westward was the long line of ponds and lakes, the red-tail's favorite huntingground, while to the north lay the broad expanse of water, and in the distance loomed up the domelike peak of St. Helens, covered with perpetual snow.

How could we ever secure a good series of pictures at such a distance from the ground? It looked impossible at first, but a careful examination showed a rare arrangement of nest and branches. If we could but hoist our equipment there was no question as to photographs. Eight feet below the aerie the trunk of the tree branched and spread in such a way that we could climb to a point just above the nest on the opposite limb. We strapped the camera in a crotch that seemed built for the purpose, with 
the sun coming from the right direction. The trouble came in focusing the instrument One hundred and twenty feet is not such a dizzy height when you stand on the ground and look up, but it is different when you strap yourself to the limb of a tree and dangle out backward over the brink. No matter how strong the rope, there's a feeling of death creeping up and down every nerve in your body the first time you try it.

The eggs of some hawks differ widely in marking, but the two we found in the cottonwood year after year were always of a bluish-white tint with pale lavender shell markings. In her period of housekeeping the mother seemed to understand the changes of season. She cradled her eggs about the last week of March, before the trees had leaved out, so that during the time of incubation she had a clear view of the surrounding country. When the hawklets were hatched and she had to go back and forth carrying them food, and when the young began to move about in the nest and peek over the edge, they were well protected from a view below as well as from the sun and rain above by the thick surrounding foliage.

The red-tail is often called "chicken-hawk," but he does not deserve the name. Many of the hawks carry reputations that they do not deserve. Often people who live in the country are enemies of the hawks and owls and shoot them at every opportunity, because they think the hawk is the persistent foe of poultry, whereas this is a very small part of his diet. In regions and in seasons when animal and insect food is scarce this hawk may catch chickens and game birds, but it lives mostly on mice and shrews as well as frogs, snakes, lizards, and insects of vari- 


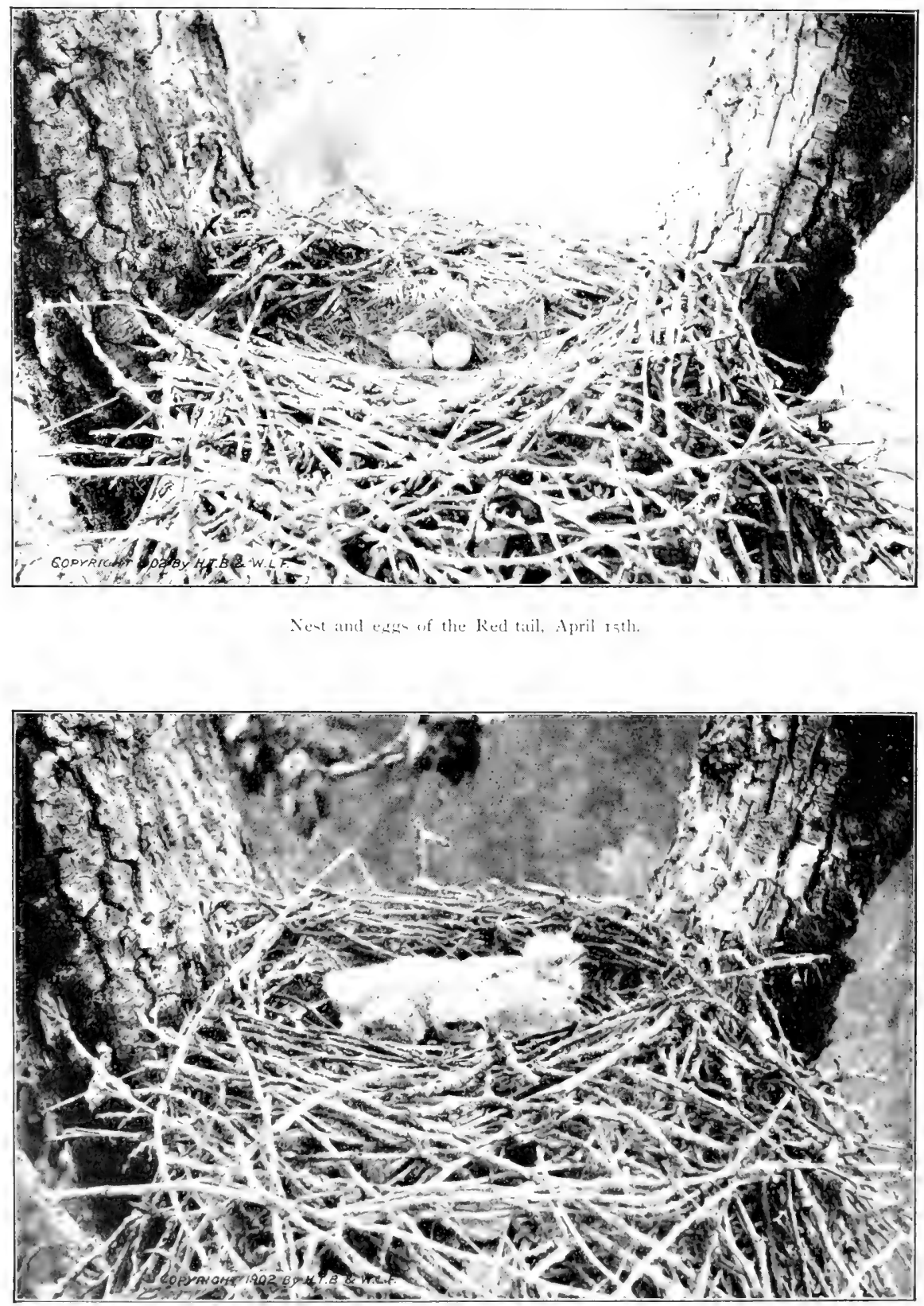
ous kinds. In a prairie and hilly country almost its entire food is squirrels, gophers, meadow-mice, and rabbits.

It has been shown by careful ex.mminations of hundreds of stomachs of these hawks, carried on under the direction of the Department of Agriculture at Washington, that poultry and game birds do not make up more than ten per cent of the food of this hawk. All the other helpful animals preyed upon, including snakes, will not increase the proportion to fifteen per cent, so there is a balance of eighty-five per cent in favor of the red-tail. This is a fact that every gunner should remember, since the hawks destroy so many injurious rodents they should never be shot unless in the act of stealing chickens.

There is a charm in the life of a wild bird of prey. Like the Indian that once hunted his daily food through forest and over plain, these creatures have every sense developed to a high point for their own protection and existence. They maintain themselves by preying upon birds, fish, and mammals almost as crafty as themselves.

Off to the west of the hawk's nest, and spreading for two or three miles to the north and south, is a network of low-lying ponds and lakes. Here the red-tails fished and hunted. Skirting one of these lakes, early one morning, we came to the top of a low rise between this and the next pond. A hundred and fifty yards below, and at the edge of the timber, we saw one of the red-tails sitting on a dead stump. We crouched in the bushes and studied him for several minutes with the field-glass. $\mathrm{He}$ had not seen us or, at least, he paid no attention to our presence. Suddenly he lifted his wings and set out straight across the lake, but at the further side he seemed to 
change his mind, for he swerved and sailed back a short way to the left and suddenly dropped to the water like an osprey. With heavy flapping of wings he struggled to regain the air with the weight of a large carp that was wriggling in his talons. As soon as the hawk reached the bank he dropped the fish, evidently to let it die or to get a better grip on the load. A few intervening bushes cut off our view of the fisher and his catch, but we lay quiet till the old hawk took wing again with his fish. $\mathrm{He}$ could hardly scrape over the tops of the low willows as he labored slowly toward his aerie in the cottonwood.

That afternoon we were again at the nest tree with our cameras. The parents, as usual, discovered our approach while we were some distance from their home, and during the ascent they circled about overhead with an occasional loud scream. When we looked into the nest the fish feast was over, for only the tail-end of the carp remained. The fish was originally over a foot in length, and I should have judged it too heavy for the hawk to carry such a distance had we not seen him do it. But these birds of prey are powerful on the wing; they will sometimes attack and kill animals as large as themselves.

Occasionally a hawk will make a mistake. I have the record of one of these hawks that was seen sitting on a perch watching the ground below. Suddenly he poised and dove straight for the prey. He seemed to strike squarely, and began to rise with a small animal in his talons. The bird rose for thirty or forty feet, and then, with a scream, he began to flutter higher and higher, circling around, and all the time feathers were dropping 
from the hawk's body. He reached a height of several hundred feet when he began to descend rapidly and soon dropped to the ground. The hawk had pounced upon a weasel and had clutched it through the hips, but had not killed the little animal. Both the bird and his prey were dead when found. The weasel, in its death-struggle, had literally disemboweled the big bird.

Our young chieftains in the tall cottonwood, for so we called them, were now almost full grown. They were as large as their parents, but their heads were still covered with downy feathers. Instead of crouching timidly in the nest they stood up and walked about or perched in the crotch over the aerie. Their home, which was once nest-shaped, was worn down about the edges until it was a mere platform of sticks. While at first they assumed a fighting attitude when we reached the nest, in all our visits they never once tried to tear our hands with their sharp beaks. How they watched us with those large eyes of gray, such sharp, serious eyes! No movement of ours escaped their gaze. After several visits to the aerie we learned to regard the hawklets with a sort of love. A glimpse of those wild creatures in their home well repaid us for the long trip, the ascent of the tree, difficult and dangerous as it was. We longed to take them with us so as to study their habits, for in a few days they would be forever beyond our reach. But what satisfaction could we have had in watching these birds behind prison bars? I should much rather have had their dried bones. Anything but a hawk or an eagle in a cage!

Conditions had changed somewhat in the vicinity of the hawk's nest by the first of June when we made our 
last visit. The river had risen and covered the lowland. The water had come up to the base of the tree, and we reached it only by wading through the woods for half a mile with the cameras strapped to our backs. The warning screams of the parents gave assurance that the home was not yet deserted. Peering up through the foliage with our field-glass we saw two young braves straining their necks and watching us over the edge. When we reached the large fork below the nest, one of the parents swooped downward and swerved above the nest with a loud scream. If it was a command it was instantly obeyed, for the young hawks spread their wings and skimmed out over the trees and on up the bank of the Columbia.

We made a close study of the red-tail's home in the tall cottonwood. He was always a successful hunter. In all our visits we never saw the time when his larder was empty. Nor did we find that he had to resort to the chicken yard for food. There was plenty of wild game. On the first visits we found the remains of quail and pheasants in the aerie. One morning we saw the mangled body of a screech owl; almost a case of hawk eat hawk. The old red-tail had evidently found the victim returning home too late in the morning, and there were no restrictions as to race and color in the hawk household. Later in the season, when the banks of the Columbia overflowed and covered most of the surrounding country, the old hawk did not abandon his own preserve. He turned his attention entirely to fishing. Where the carp and catfish fed about the edges of the ponds he had no trouble in catching plenty to eat. Twice we found carp, over a foot in length, in the aerie. After that we saw no sign of food other than 


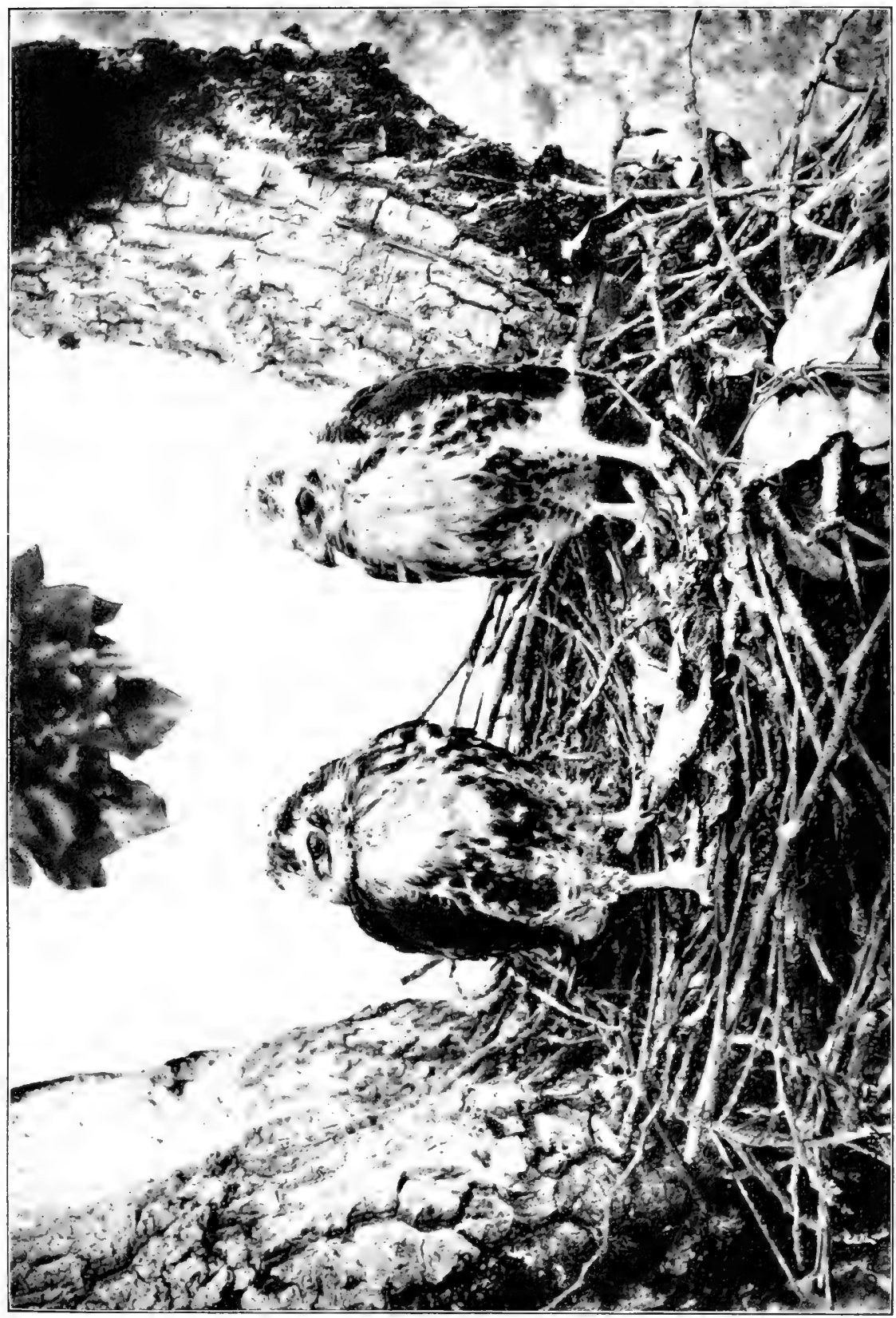



fish, and on our last visit we picked up the head bones of seven catfish.

The wild life of the red-tail has a fascination for me. $\mathrm{He}$ is as interesting as a person. He has a character as clearly marked as that in any feathered creature I ever saw. The bleak winter winds that sweep the valley of the Columbia and drive the other birds to the southland, never bother him. This is his permanent home. $\mathrm{He}$ is not a vagabond. He is local in his attachments and habits. This is his hunting ground. He won it by years of defence. He beats over the field and along the edge of the woods as regularly as the fisherman casts his net. He has his favorite perch. He watches the pond as closely for carp as the farmer watches his orchard. His routine of life is as marked as any inhabitant along the river. Nor can I believe he is lacking in the sentiment of home. He adds sticks to his house and enlarges it year by year. Who can say that the old aerie is not fraught with many hawk memories of the past?

\section{THE HAWK FAMILY}

The Hawks are medium or large-sized birds of powerful build. They have strong, hooked bills and well-developed feet and talons. Their flight is swift and dashing, and they catch their prey by watching and swooping with great speed. They live largely on rabbits, squirrels, gophers, and insects; some species capture birds and chickens.

Red-tailed Hawk (Buteo borealis), Red Hawk, Hen Hawk: Male and female, above, dark brown, marked with white and gray; breast, whitish and buff, streaked across belly with brown; tail, rusty-red with black band near end. Common resident throughout eastern North America. Nests in March, generally in a tall tree in the woods. Eggs, two to four, dirty white, blotched with purplish-brown.

Western Red-tailed Hawk (Buteo borealis calurus): Same as above species, but darker in color. Lives from the Mississippi to the Pacific. 

JACK CROW 


\section{NII}

\section{JACK CROW}

ATER the heavy shut-in winter period, the first A spring day sets my being all ajump to be out and away across the hills and the fields, to be refreshed by the gladness of the new sunshine and brought out of my winter sleep with the other creatures of Nature.

One morning early, when spring was not yet old, the call came to me and I was up and afield with the sun. I was eager to be out among the wild folk, and see their joy in the good weather and their calmness and rest in the sunlit woods.

Were you ever in a hurry to get to the woods? I was that morning, but I didn't want to seem too anxious to myself, so I sauntered down the path and struck off through the rows of corn toward the dark grove hemming them in. I was not at home, and the charm of a strange land was with me.

The green corn-field lay in the hollow with the big woods all around. Just at the corner of the field, between the tall pines and the rustling corn blades, I picked up a young Crow (Corvus americanus) with his wing hurt. Surmising that there were others somewhere near, I began a hunt and found two more little black fellows in a nest in an old pine. It was a real crow home, with the rough sticks piled hastily in the crotch of the old storm-broken 
pine. But looks were deceptive, for built into that rough foundation was a closely woven warm nest. Here, between the forest and the fallow land, the provident parents had had an eye for a snug home, with an easy living close by, but the gun of an angry farmer had made orphans of the young birds.

The crow is a peculiar piece of birdhood. His jetty color surely was not given him for protection, so perhaps his wits were. Crow wit isn't very deep, but it is certainly always ready for use. He is suspicious and always sees a trap in the simplest thing, yet his curiosity can't let it alone. He is always up and stirring for mischief. Let a simple owl appear, and this black villain will heap a load of never-suspected crimes upon the foolish night-bird, and call all of his neighbors to the trial, in which he himself renders judgment. Then, after thus aiding public justice, he will turn around and steal anything that strikes his fancy, whether he needs it or not. He needs it-just because-that's all! How can he help being a thief? He can't help crow nature. Besides, he is such a cheerful bandit, with a gentle, self-confident way of taking things from under your very nose. There is ever a hopeful, expectant expression on his face, and, even when he is caught, he puts on a don't-care look and immediately hunts up more trouble.

The crow walks the earth as if he belonged there. In fact, everything that he touches belongs to him. Other birds drop down and snatch food from the ground, but Master Crow walks about and takes his choice as if it were all put there for his selection. It isn't impudence; it's a spirit of community rights with man. 


\section{Jack Crow}

We made a home out of a dry-goods box for the three little waifs, and they seemed happy in their adoption. It was interesting to watch them play. When they were little fellows and couldn't fly much and had to help themselves along with their wings, they would gather about the old splitting-block in the back yard and chase each other around and around. Sometimes they hopped over the block, chippering and cawing all the time as if they really understood and enjoyed it. It looked like real baby play.

They had another game which seemed to bring out all the humor in their bird natures, though you never would have guessed it by their faces. They would get a piece of paper, or something light, and all climb up on the block, and one of them would drop it off. The other two would make a dive for it as it fluttered down, and one of them would get it. It was his turn then, so they stalked slowly back and again took their places on the block. And so the game went. They were only little chicks and often it took three or four tries for them to get over the big block. Finally, they would make such a racket that old Jack, the dog, would interfere and pitch into them as if he were going to eat them alive, and then they would scatter and do something else. As they grew older, baby ways were forgotten. Crow craft took the place of amusement, and they were stealing and hiding things instead of playing.

The three little crows lived with us for several weeks. One night there came on a cold snap late in the season, and in the morning we found two of the birds dead in the box. The cripple was left.

After the two crows were gone the one that was left 
seemed to have a closer companionship with us. He was alone and a cripple; he needed our care and we gave it. He was a joy and a sorrow at the same time-a joy to watch his quick, bright ways, but a sorrow to have any dealings with him.

When Jack Crow was little he would sit up and beg us to feed him, his wings fluttering and his bill stuck straight up so you could see nothing but a hole in his head. And all the while he was caw-awing at us. We fed him everything. Fish-worms, berries, and soaked corn were the main part of his diet. He was particularly fond of hominy.

The weather continued cold and we were afraid the young crow would get chilled and die, so one night we put him to bed with old Jack, our dog, and after that we could never get them apart. Jack Crow made a regular den out of the kennel, and it seemed to me that old Jack was consenting to lawlessness in the community when he allowed his black companion to bring in his booty and store it away.

It was all "jug-handle" love between the two Jacks. Jack Crow clung to the old dog for warmth and safety. His was a politic friendship. But it was different with old Jack. His dog fidelity told him to protect the little black bird, and that was enough for him. There was no such faith in the crow's creed. He took toll from friend and foe. A dinner call for "Jack" brought both. Two dishes were set out and each knew his place, but Jack Crow had a short memory. He left his own dish and stood close to the dog's plate, watching him eat. $\mathrm{He}$ seemed to measure every bite old Jack took, and every 

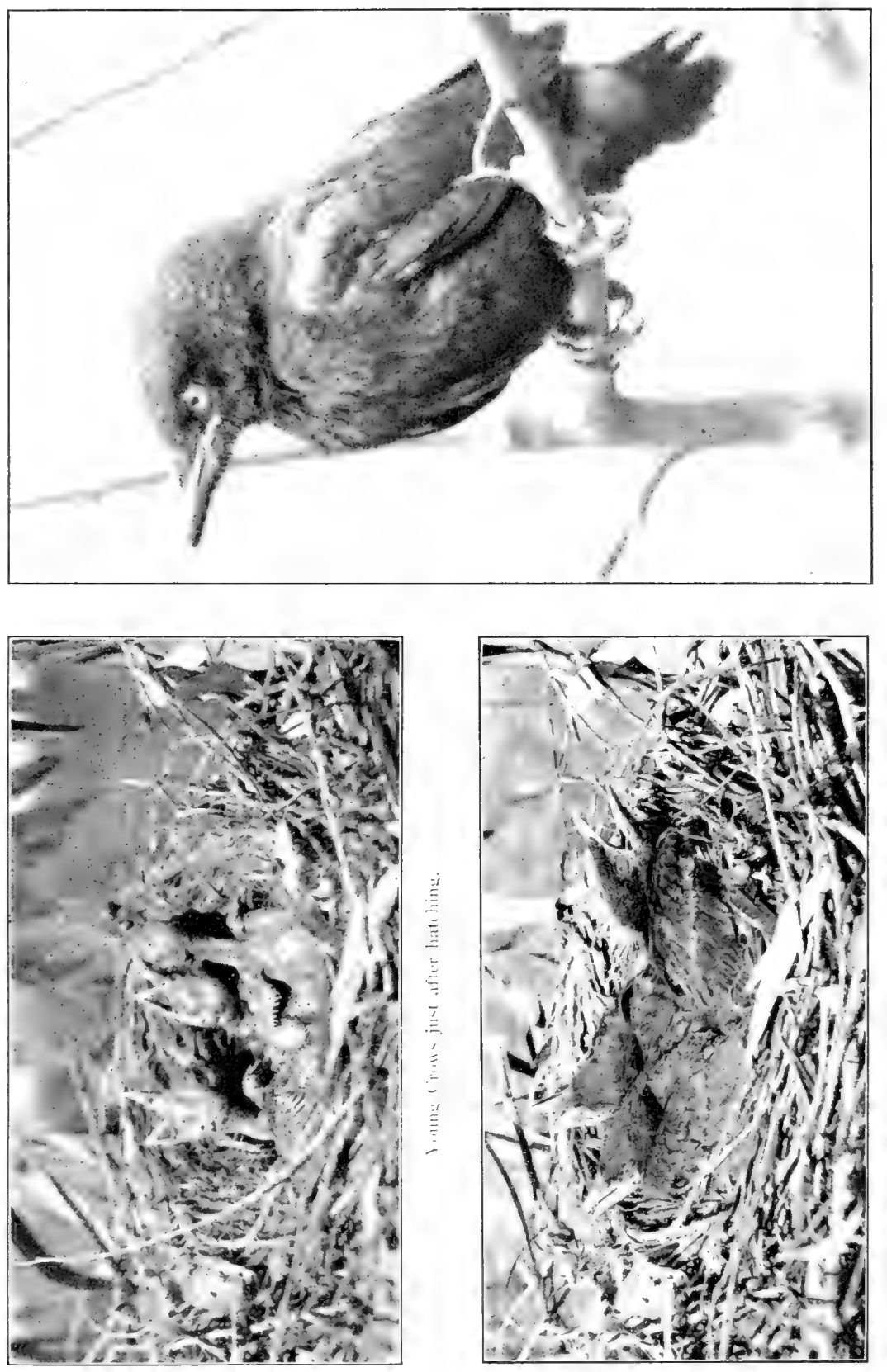

now and then, when the dog stopped gobbling to take a breath, he snatched a chunk and scuttled off as fast as his lame wing would let him. Old Jack's wrathful growls were his only consolation, for the crow perched just out of reach and ate his stolen bit or stowed it away in some conspicuous corner. The dog's grievances were soon forgotten, and the crow went tagging him all around the yard, hitching along as fast as he could and jabbering in an excited, impatient way.

The children, the dog, and the crow were boon companions. In summer they went blackberrying together. When they started out the crow always rode on some one's shoulder, but when they came back he was in a much bigger hurry to get home than the rest and flew on ahead. When they arrived they found him skirmisling for something to eat or up to some of his tricks.

Jack Crow's wings were never clipped. He stayed with us of his own free will. He never entirely severed his relations with his own kind, for he used to go out in the corn-field with the flocks of tramp crows that came to forage. We expected to see them resent his company, since it generally seems to be the case that wild crows hate a crow that is tame and lives with man, and they treat him as a traitor to the race. But if Jack got such treatment we never knew it.

We were always afraid when the men went out in the field to shoot crows that they would kill our pet. So we watched the proceeding with anxiety. Once or twice, when they scared up the flocks of birds, old Jack was along, and Jack Crow saved his own life by flying out of the flock and lighting on the dog's back. All through the summer 
and fall, when he was young and growing strong, he went out in the corn-field at will, but dusk always brought him home.

Is it strange that there should be bird friendships? Isn't it natural and necessary that the wild creatures who brave the outdoor hardships should need the encouragement and backing of their fellows? Perhaps in the days of their prosperity, in the joyous, sunny nesting time, they forget their friends and past favors; but it is only for a time, and the ingratitude isn't very deep. Besides, they are all busy with household cares and don't miss each other. But in the fall when family duties are over, and parents and young are ready to begin their travels to the southland, they remember that company makes the cold nights a little less cheerless and shortens the miles of flight.

There are very few of our common birds that do not flock some time in the year. Some, like the water birds, both of the coast and the inland, live together all the time - the gulls, cormorants, pelicans, and terns. And many of the land birds prefer to live together in colonies, such as the swallows, blackbirds, and crows.

The crows are very clannish at all times of the year. When the season of home-building comes they sometimes select a site and several pair will nest in a locality. Of course, they may not be very neighborly at this time, but they like to have the assurance of their kind close by.

When the crows begin to flock the farmer feels that winter is already at hand. When the first chill winds heralded the winter, and the little corn-field in the hollow was but a patch of sear stalks, the black foragers of the summer came trooping in to the shelter of the thick pines. 


\section{Jack Crow}

In hundreds they came, and blackened the sky as they passed, to alight in the skirts of the woods and turn their shade to ebon. The small flocks for miles around seemed to collect to form one great winter camp in the old pine forest.

In the daytime they departed for the few meagre feeding-grounds that had been hunted up over the country. A big flock usually took the lead, sailing straight in a dense mass, and followed by a few scattering small flocks, while far in the rear came the stragglers who had forgotten to start on time.

Sometimes great numbers of them lined the old rail fence. In the fall an old rail fence and a crow belong to each other. There was a change in their attitude now. They were not bubbling over with life as a few months ago. Even curiosity was dulled. They had put on the mood of another season. They sat with heads hunched down between their pointed shoulders, and they sat for long spells. There was something ominous in their quiet. Winter meant something worse for the crows out there in the cold than it did for the farmer and his pet crow in his snug nest with the old dog at home.

Jack Crow weathered the winter in happiness. In the yard there was an old half dead apple tree where he used to sit and jeer at the dog, when he had been nipping some dinner. But the dog wasn't the only one who scolded the little torment. This old apple tree was the crow's favorite den, and here he stored his treasures. He retreated here for safety and, perched on a limb out of reach, he would cock his head on one side and listen gravely to the powerless threats sent up to him. We never could 
teach him to talk, and it was well for Jack he couldn't lest he might have told many of his sins we never discovered.

Bright-colored objects and things that glittered seemed to attract him. Although he couldn't string his treasures and wear them around his neck like an Indian, he never lost the enthusiasm of a collector. A thimble was missed in the house and the children were accused of misplacing it. It was not found till a year later. When the old apple tree was cut down, up in a hole in the fork were found the thimble, a teaspoon, and a lot of broken glass and other trinkets. The finding of Jack's storehouse cleared up many little troubles for the children.

There used to be a current notion, which probably was well founded, that crows would rob hens' nests. Jack Crow's farmer-father said that if he ever got to robbing nests he would have to be killed. But he never did. He kept his thieving to the more petty, annoying thefts around the house. But he lived up to crow character every bit and never let the grass grow under his feet. When he could sneak into the summer kitchen he would hop on a chair, and then upon the table, and snatch things when he thought no one was looking. Stealing was pure delight to him.

A crow likes company as a chicken does. But he can't be placed in the same class with chickens. What a sputtering in the barn-yard when the crows flew over! But the chickens were friendly to Jack, for in winter he ran around with them, picking up extras beside what he got from the table. Jack considered everything a gain.

He stayed with the family the whole of one year. Early 


\section{Jack Crow}

the next spring when the crows first began to come he would flap off down the corn rows with them, getting acquainted perhaps. At night he would come back to the house if the children and old Jack did not hunt him up before. Gradually he got to staying out nights, and finally he would be gone for two or three days at a time. At last he didn't come back at all. We never knew whether he was taken back into crow fellowship, or whether he departed to a new land to begin life over and live as a thoroughbred crow should.

After he left, the children often took old Jack and went down in the corn-field to look for Jack Crow. They scared up all the flocks they could find, but never again did they see Jack Crow fly out from the swarm of black wings that fluttered up into the pine trees on the skirts of the field.

\section{THE CROW FAMILY}

This is a large family, including jays and magpies. The Crow is everywhere known because of the black coat. This family has no musical ability, as the voice is either hoarse or harsh. The crow walks firmly and easily on the ground while the jay hops. The crow is about a foot and a half long; he lives on small mammals, cutworms, grain, fruit, and the eggs and young of other birds.

American Crow (Corvus Americanus): Male, plumage, glossy black with purplish tinge; bill and feet black. Female, less brilliant. Lives throughout the United States, summer and winter. Nest, generally in evergreen trees, a platform of rough sticks lined with bark, weeds, and leaves. Eggs, four to six, greenish, spotted with brown. 
THE OWL, BIRD OF NIGHT 




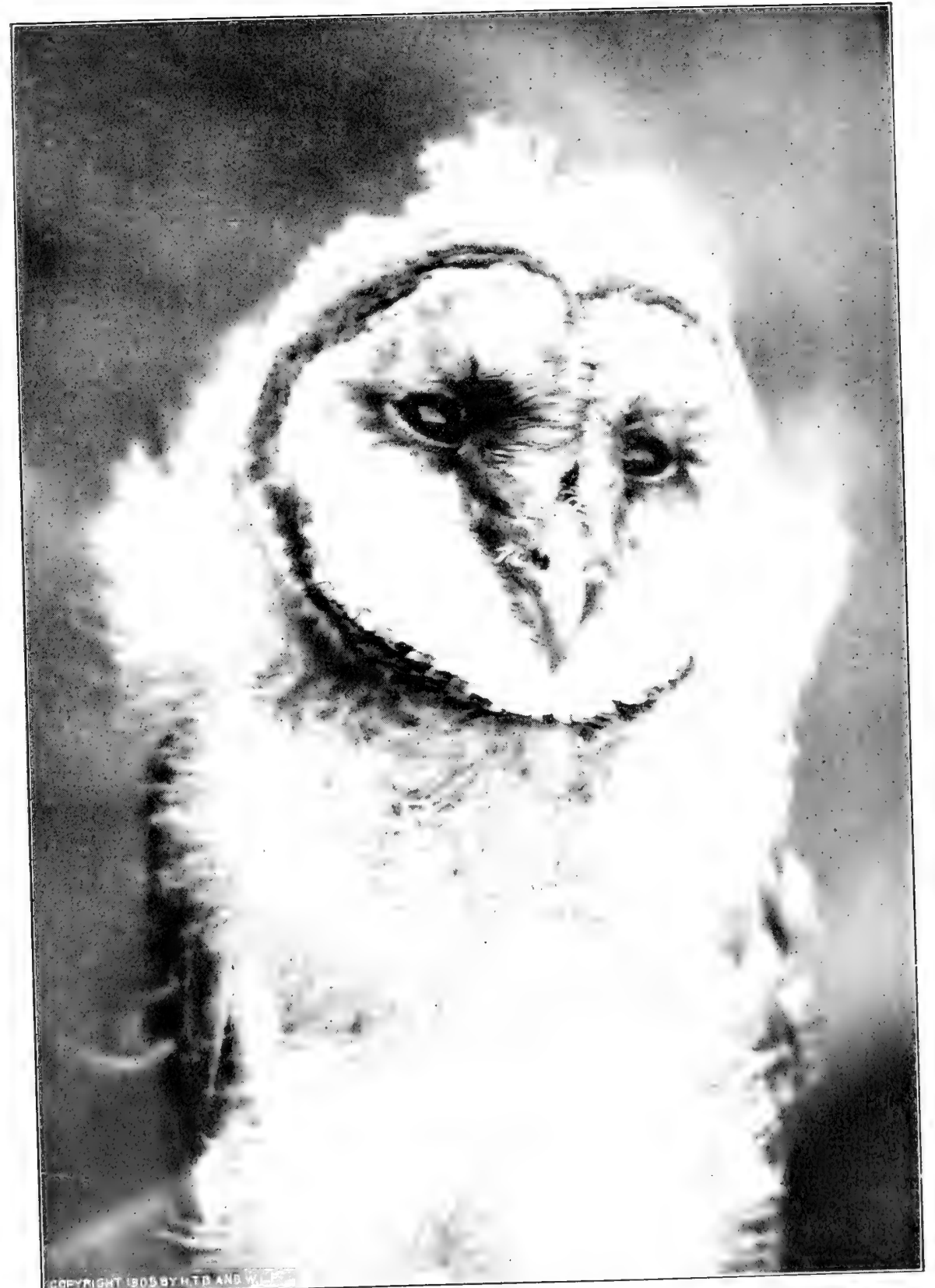

"Granny" - a portrait of a half-grown Barn ()wl. 


\section{VIII}

\section{THE OWL, BIRD OF NIGHT}

THERE is not a tumble-down barn in the country that 1 does not shelter good material for a naturalist's note-book. Take it all in all the old shacks are the most productive. If there is a hole and a snug corner some wren or bluebird has likely climbed in and built a home. If it be near town some English sparrow has perhaps been living there all winter, and, at the first sign of spring, has begun carrying in grass and sticks. Or, if the barn is very shaky and leaky, it may make a home for an owl.

The Barn Owl (Strix pratincola) is not hard to please when he needs a nesting place. He takes the steeple of a church, an old hollow sycamore along the creek, or a cave in the mountains. I know of one pair that has lived for years in the tower of a court-house. The town clock just below the nest must have been a nuisance at first during the day-sleep, but it was likely taken as something that could not be helped, as we take the clang and rumble of the street-cars under our windows at night.

Years ago our nearest neighbor got a pair of pigeons, sawed two holes up in the corner of his barn and nailed up a soap box for them. The pigeons disappeared one day and the next spring a pair of barn owls moved in. That was seven or eight years ago, but the old dusty box in the gable is still rented to the same pair. I have no doubt they will stay as long as the barn lasts. 
Our neighbor says his barn is worn out, and resembles Mr. Burroughs' apple tree, which was not much good for apples but always bore a good crop of birds. The owl home is a valuable asset of the barn. The owner knows something of owls as well as of fruit trees; no other barn about the neighborhood shelters such a valuable family of birds, and he guards them as closely as he guards his cherries. The nest has never been robbed, and when we spoke of photographing his owls he looked doubtful until we promised him the birds should not be harmed.

The barn owl is a queer-looking tenant. No one is very fond of an owl. More than that, his actions are against him. It's natural that we should not care much for a fellow who is up and sneaking around all night and sleeping through the day. There is always some suspicion about a night-prowler, whether he be bird, man, or beast. However, I have often watched the barn owl, and have studied his habits, so that I am sure he did more for our neighbor in one night than the pigeons, swallows, and wrens did in a month. Not in singing, mercy no! Who ever heard of a song coming from a hooked bill? It was in real service about the farm, as watchman or policeman, to rid the place of injurious animals.

It was not an easy matter to photograph these barn owls in the very peak of the old barn. The minute we came near the nest box the old owl pitched headlong out of the hole and landed in a willow tree opposite. We had to climb a ladder and swing into the rafters to reach the nest. In such a place we could hardly handle a camera. There was not even a loft to work from, so we set up a long ladder and nailed to it a couple of cross-pieces strong 


\section{The Owl, Bird of Night}

enough to hold a board. Crawling up in a stooping position we took the back out of the nest box and fixed it so that it would drop down to show the inside, and then could be fastened up again.

A month later we climbed up into the gable end of the barn and pulled out three of the funniest, fuzziest, monkey-faced little brats that I have ever set eyes upon. They blinked, snapped their bills, and hissed like a boxful of snakes. We took them to the ground and doubled up in laughter at their queer antics. They bobbed and screwed around in more funny attitudes in a minute than any contortionist I ever saw.

We found them graded in size and height, as carefully as a carpenter builds the steps of a staircase. They were lumpy-looking, as if some amateur taxidermist had taken them in hand and rammed the cotton in, wad at a time with a stick, till he had the youngsters bulging out in knobs all over.

The eldest we called the colonel, but looking at him from a humanized standpoint, it seemed to me he had been put together wrongly, for his chest had slipped clear around on his back. At times he was a peaceable-looking citizen, but he was always shy and cautious. He turned his back on the camera in disgust, or sat in a sour state of silence, but one eye was always open, watching every movement we made.

While the nestlings were in the downy stage the mother always stayed with them during the day. She seemed to be a widow, with triplets on her hands, for we never saw the father. If he came to see the children or to help in the house it was only in the dark of the night. 
When the nestlings grew older the mother slept in the cypress tree during the day. Twice I tried to climb the tree to get a good view of her, but each time she flew out as soon as I got a few feet up. She seemed to have no trouble in seeing by day as well as by night, but the eyes of the owl are undoubtedly much keener after dark.

We crept out one night and hid in a brush-heap by the barn. It was not long before the scratching and soft hissing of the young owls told us their breakfast-time had come. The curtain of the night had fallen. The day creatures were at rest. Suddenly a shadow flared across the dim-lit sky; there was a soundless sweeping of wings as the shadow winnowed back again. The young owls, by instinct, knew of the approach of food, for there was a sudden outburst in the soap box like the whistle of escaping steam. It was answered by a rasping, witching screech. I thought of the time when we used to creep out at the dead of night and scare an old negro by drawing a chunk of resin along a cord attached to the top of an empty tin can. Again and again the shadow came and went. Then I crept into the barn, felt my way up, and edged along the rafters to the henroosty old box. Silently I waited and listened to a nasal concert that might have come from a cageful of snakes. As soon as food was brought I lit a match, and saw one of the little "monkey-faces" tearing the head from the body of a young gopher.

The barn owl kills the largest squirrel quickly and easily, for the animal apparently terror-stricken does not show much fight. With sharp talons stuck firmly into the 



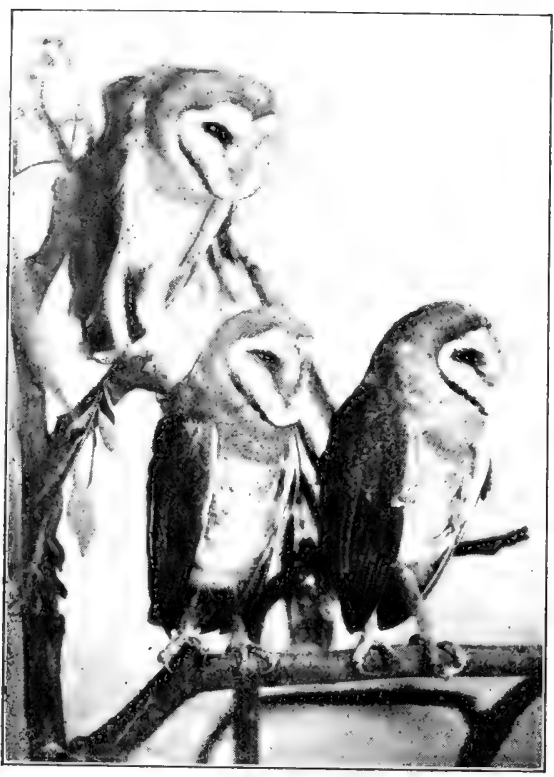

Full-grown young fiarn ()wls at the age of eight weeks.

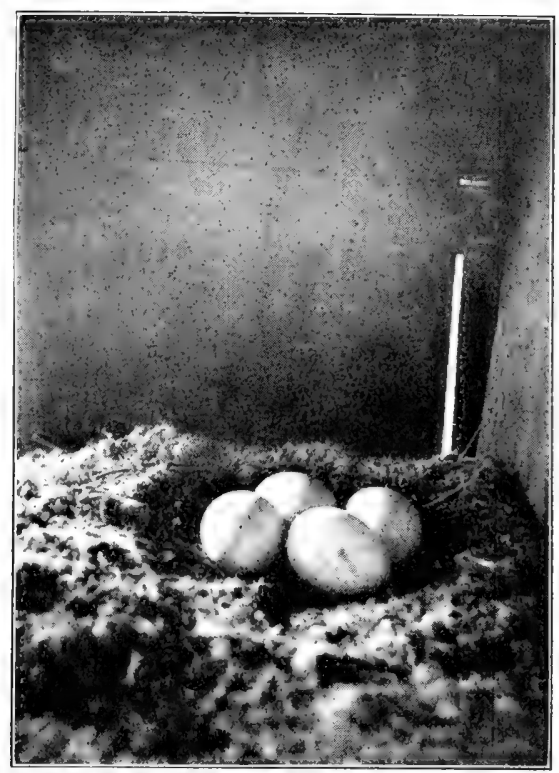

Nest and egus of the liarn ( $) w l$.

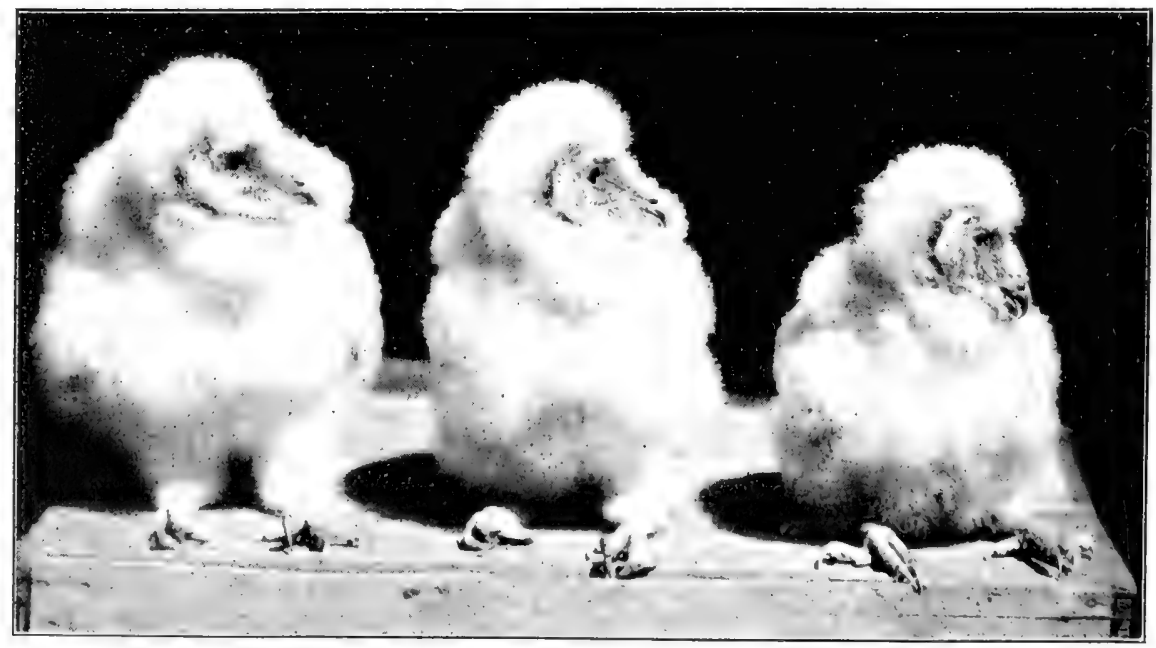

Downy young Parn ()wls about three weeks shl. 


\section{The Owl, Bird of Night}

back of the squirrel, and with wings spread, an owl can break the animal's neck with a few hard blows of his beak. The head is usually eaten first, either because that is a favorite part, or because the destruction of the head gives the bird better assurance of the animal's death.

The next time I climbed the cobwebbed rafters to photograph the young owls I cautiously thrust in my hand to pull out the nearest nestling. In a twinkling he fell flat on his back and clutched me with both claws. Of all the grips I ever felt, that was the most like a needle-toothed steel trap. I felt the twinge of pain as the sharp talons sank into the flesh. I cringed and the grip tightened. The slightest movement was the signal for a tenser grasp. It was the clutch that fastens in the prey and never relaxes till the stillness of death follows. I hung to the rafters and gritted my teeth till I could wedge in my thumb and pry the claws loose.

The young owls were hardly old enough to fly, but they could raise their wings and run like a cat for the darkest corner. We had never tried the camera on such a ferocious lot of birds. They knew the art of selfdefense like a professional prize-fighter. Approach one, and he was on his guard. He would turn on his back in a second and throw up his claws. "Come on, I'm ready," he seemed to say, and we kept our distance. The oldest one had a villainous temper; he was as much opposed to having his picture taken as a superstitious Indian. Generally he sat with his chin resting on his chest like a brokendown lawyer. Once, when the photographer was least expecting it, he dropped on to his trousers' leg as lightly as a feather, but with the strength and tenacity of a mard 
bull-pup. The claws sank through to the flesh, and before they could be pried loose they had drawn blood in three places.

All birds of prey swallow a great deal of indigestible matter, such as the fur and bones of animals and the feathers of birds. After the nutritious portions have been absorbed, the rest of the mass is formed into pellets in the stomach, and is vomited up before a new supply of food is eaten. By the examination of these pellets, found about the nest or under the roost, a scientist can get a good idea of the character of the food that has been eaten. Besides, one generally finds in the nest the remains of creatures upon which the young birds have been feeding.

The birds of prey are well able to fulfil their mission in the world of natural things. All parts of the organic world are linked together in a thousand ways, and one form of life is dependent upon other forms, while the whole has been summed up in a general law called the "balance of nature." If, for example, we were to kill off our birds of prey, we would have no check against the rodents that infest our fields. Nature made these birds with strong wings and acute eyes; she gave them powerful claws to pierce the entrails of the small animals, and strong, hooked bills for tearing the flesh. They digest food so rapidly that they are continually on the hunt, and eat a large amount each day.

The owls as a family are the most helpful birds of prey to the farmer. With few exceptions they are night hunters. Their eyes and ears are remarkably acute, and are keenest in the early hours of the night and morning. Many harmful rodents are most active in their search for 


\section{The Owl, Bird of Night}

food during the night, and the owls are the natural check upon them. The hawk hunts by day and the owl by night, and the work of one supplements that of the other.

A pair of barn owls occupied one of the towers of the Smithsonian Institution at Washington. When the young were half-grown the floor was strewn with pellets. An examination of two hundred of these showed a total of four hundred and fifty-four skulls. Four hundred and twelve of these were mice, twenty rats, twenty shrews, one mole, and one vesper sparrow.

A family of young barn owls will number from three to seven birds. It is hard to believe what an amount of vermin a family of owls will consume. An old owl will capture as much or more food than a dozen cats in a night. The owlets are always hungry; they will eat their own weight in food every night, and more, if they can get it. A case is on record where a half-grown owl was given all the mice it could eat. It swallowed eight, one after the other. The ninth followed all but the tail, which for some time hung out of the bird's mouth. The rapid digestion of the birds of prey is shown by the fact that in three hours the little glutton was ready for a second meal, and swallowed four more mice. If this can be done by a single bird, what effect must a whole nestful of owls have on the vermin of a community?

I wondered at the changes in the owl faces as they grew older. When I first saw them in white down, I thought the face was that of a sheep, and then a monkey, and then I didn't know just what it resembled. The third time we visited the nest each youngster had a face that surely looked like some old grandmother dressed in a nightcap. 
Later on, when we saw them full-grown, they had grown to be more owl-like and dignified.

An owl spreads terror among the small ground folk as a ghost among negroes. It is the owl's shadow-silent wings, his sharp, sound-catching ear, and his night-piercing eyes that make him the superior of the mouse, the mole, the gopher, and the squirrel. He fans over the field with an ominous screech that sets a mouse scampering to his hole, but his ear has caught the footstep; those wings are swift, those steel trap claws are always ready; his drop is sure, his grip is death.

It would be difficult to point out a more useful bird than the barn owl in any farming country. Like many other birds, it deserves the fullest protection, but man is often its worst enemy.

\section{THE OWL FAMILY}

The Owls are distinguished from all other birds by having very large heads. The large, round eyes looking forward instead of sidewise give a full-face view. The bill is hooked; the claws long, hooked, and very sharp. They live on animal food, catching small animals, birds, reptiles, and insects at night-time. The strange and weird cries this bird makes at night connect it with things superstitious.

American Barn Owl (Strix pratincola): Male and female, face, white edged with yellowish; under parts, pure white to yellowish-brown, dotted with blackish spots; upper parts, yellowish-brown, more or less mottled with gray. Lives throughout the warmer parts of North America, where it nests in February and March. Nests in hollow trees, caves, towers, and belfries. Eggs, from three to eight, dirty white. 

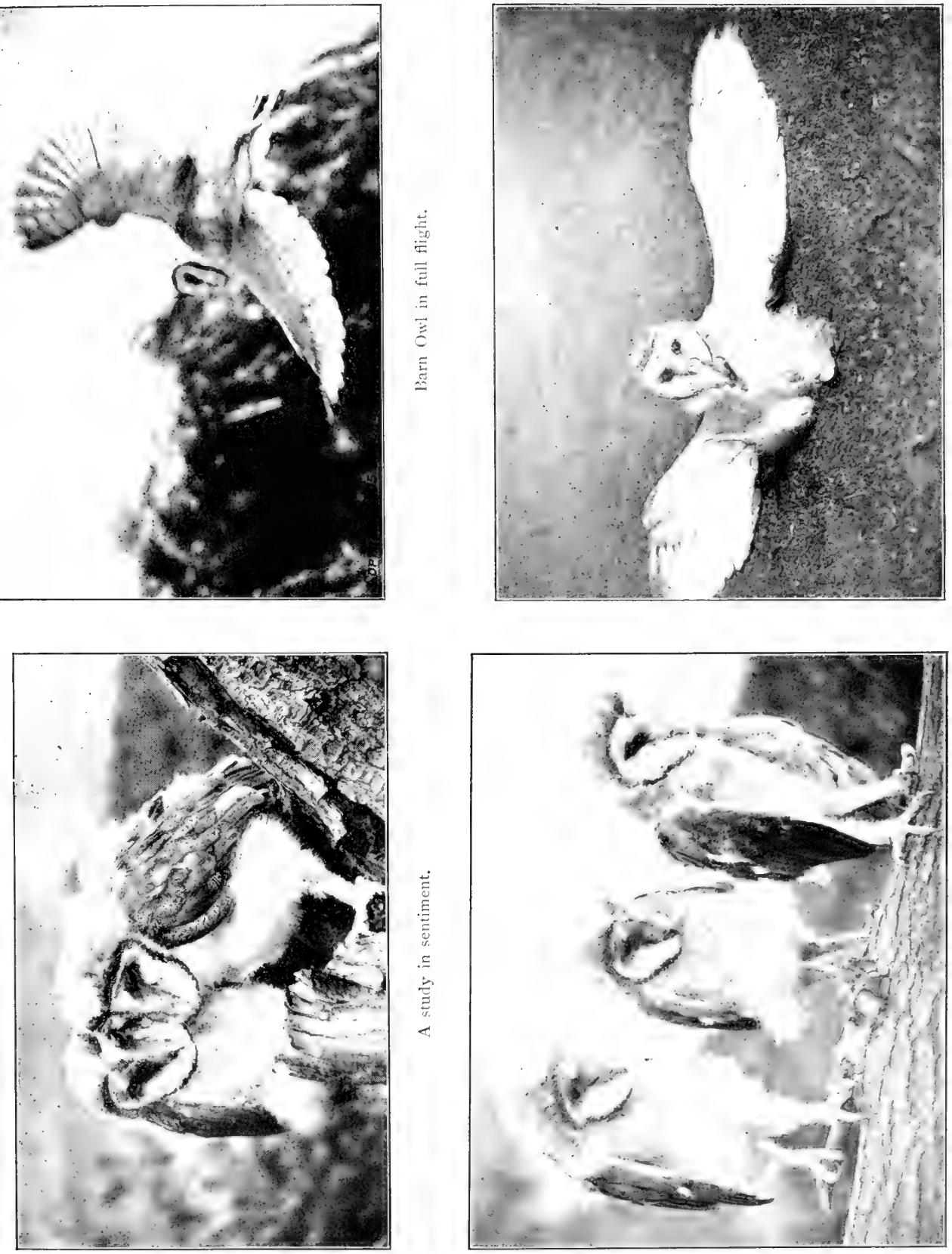

REARING A WREN FAMILY 



\section{IX}

\section{REARING A WREN FAMILY}

WHY shouldn't a little wren have an enormous appetite?" I mused, as I lay hidden in the tall grass watching the father as he fed the eldest of the family of five, that had flown for the first time from the nest in the hollow stump to the alder branches below. "Of course we admit that the tiny bobtailed youngster must have the most rapid sort of double-action digestive apparatus when we remember that he is full-grown within two weeks from the day he is hatched. The chief object of his life must be to eat and to sleep."

Wrens are interesting little chaps anyhow-droll, fidgety individuals, each with great self-esteem. My interest in a certain brown family had increased with every visit for a whole month. One picks up many acquaintances rambling about the hills, but, like people, some are more interesting than others, and acquaintanceship often warms into friendship as the days pass by.

While out birding in the latter part of June I was trudging along up one of the shaded paths of the fircovered hillsides, when a little bird whizzed headlong down in its tippling flight, barely dodging my head. Both of us were rather flustered at this sudden and unexpected meeting. The moment's pause on an overhanging branch was sufficient for me to recognize the hurrying stranger 
as a Vigors Wren (Thryomanes bewickii spilurus). But I hardly had time to see just what the small white parcel was, she carried in her mouth. It may have been a white miller, soon to be thrust down a gaping throat, but this little brown bird was too wise to show me her home.

The next day, however, I stole a march, and was well hidden in the bushes near where I thought the nest must be, when the wren appeared. I hardly expected to escape that sharp round eye, and was prepared for the scolding that followed; in fact, I took it cheerfully, without a word in reply. In her bill she held a strip of snake-skin. Rather an uncanny mouthful, to be sure. She fidgeted about with her tail over her back, and then whirled away to a large upturned root covered with vines. Here she hopped about in the tangle of brier and fern, apparently forgetful of my presence; but those sharp brown eyes, behind which are generations of care and cunning gained in contact with nature, are never heedless. Her action would have deceived any other creature, but I knew her too well; at the likeliest moment, and in an eye's twinkling, she suddenly popped up into the dead body of an alder tree and disappeared into a tiny round hole.

Wrens have traditions, and, like some people, are perhaps slightly superstitious. I was not sure that a Vigors wren thought there had to be a bit of snake-skin in her home, but I do not remember ever examining the nest of her cousin, the Parkman wren, without finding it. Maybe it is for protection, as it is said that a snake will not venture where a scrap of its own skin is found. Years and years ago the first wrens must have fought for themselves among tribes of reptiles, and now the birds never think 


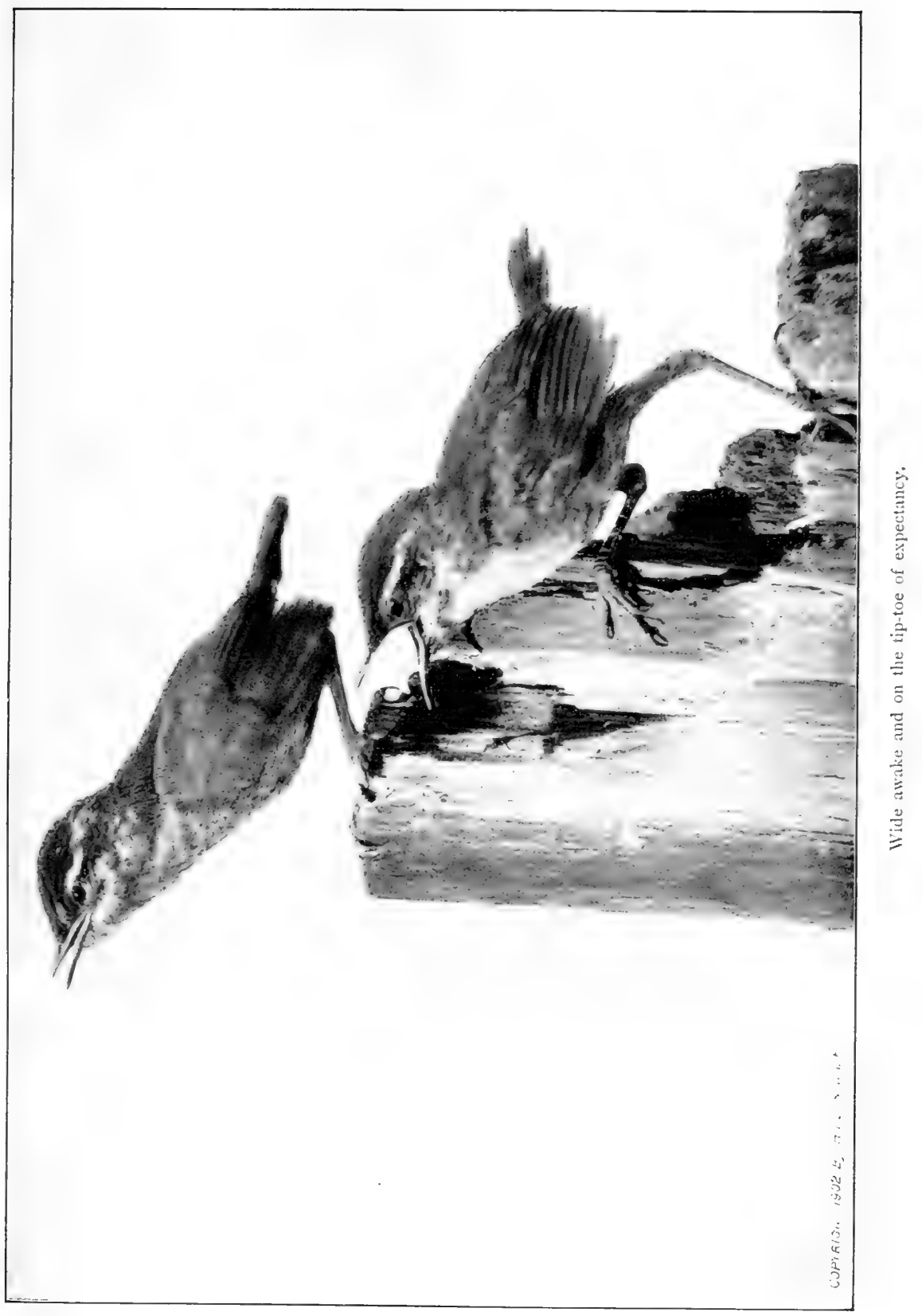




$$
\text { . }
$$


of starting housekeeping without searching up the hillsides, through the meadows, or back in the deep woods until the cast-off scaly coat of some snake is found and borne home in triumph as a safeguard.

Almost every feathered creature has some interesting trait of protection. I have always found that the redbreasted nuthatch, after he has dug out his wooden home in some dead stump, never fails to collect a good supply of soft pitch to plaster about the round doorway of his log-house.

Ever since I discovered the wren building its home in the alder stub my interest had grown, and I was anxious to win its friendship, principally because most birds had finished nesting for the season. Why had the nest not been placed nearer the ground instead of at a distance of twelve feet, and why was such a dark, narrow home chosen that I could hardly get a glimpse of the interior?

Experience had taught me not to try to win the affections of a bird too rapidly, especially at a season when it was so busy with household affairs. When I thought I could safely do so, I went up near the nest rather cautiously and timidly, and sat down in the tall ferns. It surprised me somewhat that neither parent scolded at my approach. After watching and waiting for almost half an hour and seeing neither wren, I became impatient and knocked gently on the tree trunk to pay my respects to the brown head that might be thrust from the round door above. Again I knocked, and then a little harder. It was queer that a wren could not feel such an earthquake against the pillar of her home. I shook the tree vigorously. Could 
it be possible the nest was deserted? Visions of all sorts of bird accidents flashed through my mind as I swung up into the branches and rapped at the round door. All was dark within; not even the white eggs could be seen. This was bad luck indeed, I thought. Then, with the aid of a little mirror that is always handy to examine dark cracks, I reflected a ray of light through the door to the innermost depths. There sat the mother, her brown back almost indistinguishable from the dry sides of the house, but those round dark eyes gleamed out from the gloom. Nor did she have any idea of deserting her post for all the knocking without.

When I visited the little wooden home the first week in July there was a decided turn in the tide of wren affairs. The news was heralded from the tree-tops. The energy that had been used in keeping the secret of the little home a week previous was doubled in the eagerness to spread it among feathered neighbors far and wide. For two long weeks the mother and father had covered and caressed their five eggs of speckled white until they suddenly teemed with inward life, and five tiny bodies burst forth from the prison walls.

The father wren-it is often the case-was rather timid while we were around. He had a particular fear and dislike for the great three-legged, one-eyed creaturemy camera - that was hidden dragonlike so near his home. Birds have many enemies, and a nest is seldom left without its guard. We soon discovered that this was the father's duty. His harsh, scolding note, sounded from the surrounding boughs, always reminded us that we were trespassing. 
It was the mother's duty to forage. Returning from the hunt with food she whisked about with a "what-areyou - doing - here" look of inquiry. Although flustered somewhat at first by our presence, she soon came to regard us with an air of indifference. A moment's pause on her threshold, and into the round opening she would pop; then, as if amazed at the increasing appetites she had to appease, she would dart out and away for a new supply.

About the hillside and down along the little stream the mother searched continually the entire day for grubs. Each time returning, she would pause on the top of one of the trees nearby and pipe her merry trill. This note of home-coming the father never failed to hear, and it was he that always gave the response of "all's well." I was amused to hear how readily the wrenlets learned to recognize the voice of their mother. Her song of arrival came to be answered by such a chorus of tiny cries from the round door that she could not resist hurrying headlong to the nest. Several times from my "rabbit's hole" in the bushes I saw a song sparrow stop on swaying limb and sing a song somewhat resembling that of the wren, but the children in the wooden home knew not the song, and, true to their parents' teachings, remained quiet while the doughty father darted out and drove the intruder from the premises.

On July 23d I wrote in my note-book: "This morning I was surprised to see two little brown heads as I gazed through my field-glass at the round nest hole." But how could I ever get pictures of the wren nestlings if they were to remain continually within those protected wooden walls? 
For some reason the father stormed and scolded more than usual at my next visit. He seemed out of sorts about everything. The rating I got was not very much more severe than the little wretch gave his wife when she returned each time with morsels of food. Something was very far wrong. It could not be that his mate did not search hard enough for food or bring enough back. With all his faultfinding, he never once offered to relieve his faithful wife.

Hidden in the grass, I tried to solve the secret of the father's pettish actions. Each time the patient mother returned he grew more restless and violent in his language. Soon I saw his wife whirl joyously by with an unusually large white grub-surely a prize for any bird. But, alas! For all her prowess her spouse darted at her as if in madness, while she, trembling in terror, retreated down the limb and through the bushes. For a few moments it seemed as if the wren household was to be wrecked. I was tempted to take the mother's part against such cruel treatment, as she quivered through the fern on fluttering wing toward me, but at that moment, as if thoroughly subdued, she yielded up the bug to the father. This was the bone of contention. A domestic battle had been fought, and he had won. The scolding ceased. Both seemed satisfied. Mounting to the tree-top, the little mother poured forth such a flood of sweet song as rarely strikes human ear. From that moment she seemed a different wren, released from all care and worry. Her entire time was spent in search for bugs. Each return was heralded by the highsounding trill from the tree-top, and her husband whirled out of the tangled vines to take the morsel she carried. 


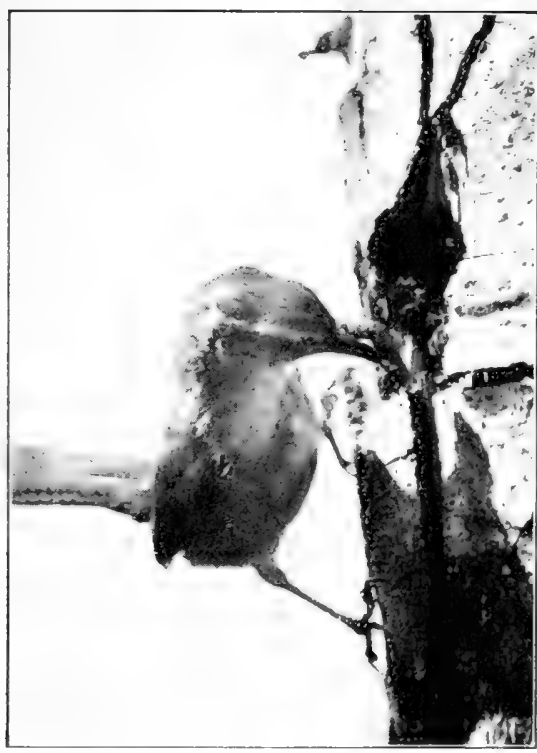

Mother Wren at the nest hole.

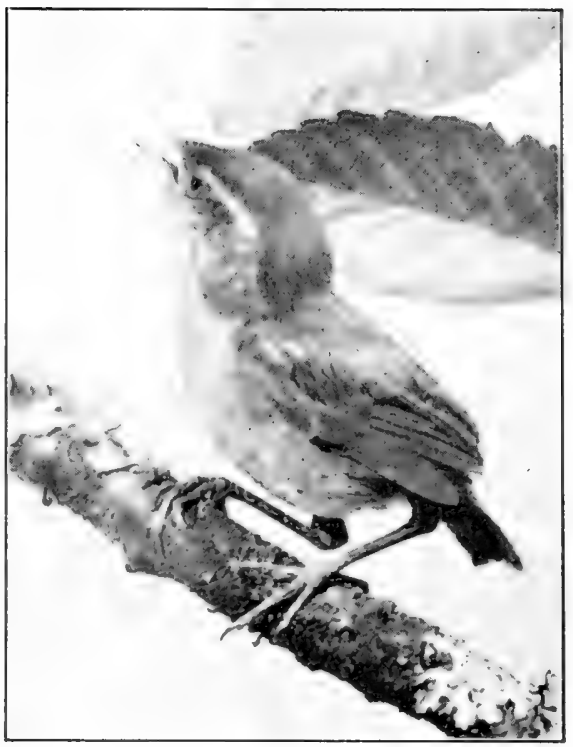

A young Vigors 1 ren just after leaving nest in the dead alder.

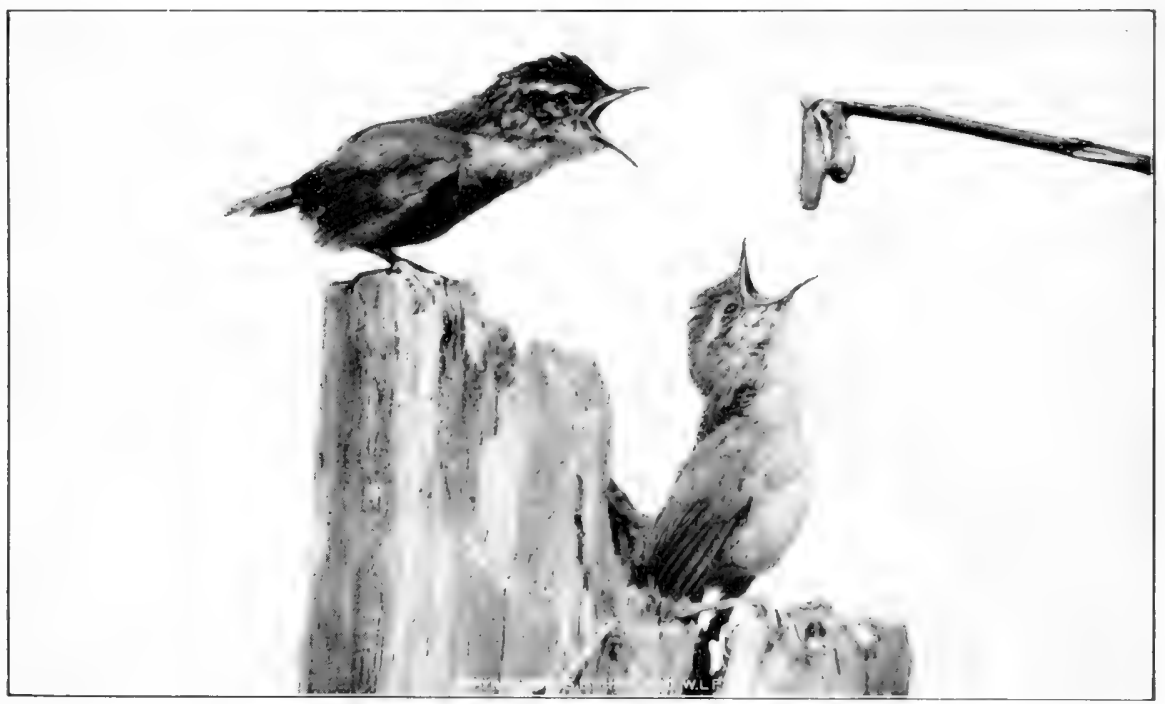

Feeding young Wrens. 



\section{Rearing a Wren Family}

But what of his actions? He had either gone crazy or he was a most selfish little tyrant, for he flew about the alder stump, calling now in a softer tone to his children within, and finally swallowed the grub himself. Two or three times he did this, until I was so disgusted I could hardly endure him. If he were hungry, why could he not skirmish for his own bugs?

While I was chiding him for his infamous action, the mother appeared with a large moth, which he readily took. Among the alder limbs he flew, and finally up to the nest hole, out of which was coming such a series of hungry screams as no parent with the least bit of devotion could resist. Hardly could I beliere my eyes, for the little knave just went to the door, where each hungry nestling could get a good view of the morsel, then, as if scolding the little ones for being so noisy and hungry, he hopped back down the tree into the bushes.

This was, indeed, cause for a family revolt. The brown nestling nearest the door grew so bold with hunger that he forgot his fear and plunged headlong down, catching in the branches below where the father perched. And the precocious youngster got the large moth as a reward for his bravery.

Not till then did it damn upon me that there was a reason for the father's queer actions. The wrenlets were old enough to leave the nest. Outside in the warm sunshine they could be fed more easily and would grow more rapidly, and they could be taught the ways of woodcraft. In half an hour, one after another, the little wrens had been persuaded, even compelled, to leave the narrow confines of the nest and launch out into the big world. 
What a task the father had brought upon himself! Surely the old woman in a shoe never had a more trying time. The fretful father darted away to punish one of the wrenlets for not remaining quiet; he scurried here to scold another for wandering too far, or whirled away to whip a third for not keeping low in the underbrush, away from the hawk's watchful eyes.

My attention was directed in particular to one little feathered subject who, each time the brown father came back, insisted vociferously that his turn was next. Once in particular, when the camera did not fail to record, papa wren was approaching with a large grub. The wrenlet was all in ecstasy. He was calling, "Papa, papa, the bug is mine! The bug is mine!" fluttering his wings in delight as he hopped to the next limb near the hesitating parent. But the youngster's emphatic appeal failed to persuade the father, for the next instant he deposited the morsel in the mouth of the less boisterous child. What a change in my enthusiastic little friend, who at one moment fairly tasted the dainty bit and the next saw it disappear down the throat of a less noisy brother. He stood looking in amazement as his feathers ruffled up in anger and an astonished peep of disgust escaped his throat.

Another day in the warm sunshine and the wrenlets began to act more like their parents, and to gain rapidly in worldly knowledge. The third morning all was quiet, and I thought the family had departed for other huntinggrounds. Soon, however, the father appeared, and then the mother, scolding as usual. I crawled down under the tall ferns to wait. The parents had taught their children the act of keeping still very well, for not a peep was heard. 
But those ever-growing appetites soon mastered caution, and, regardless of continual warnings, there was a soft little "Wink! Wink!" in the direction of the vine-covered stump. 'Twas hardly an exclamation of delight, but just a gentle reminder lest the busy parents forget. Gradually these little notes increased in number and volume till the full chorus of five impatient voices arose from among the tangle of vines and ferns.

My continued visits had made fast friends of the little fellows. Two of them took their position on the top of the stub where the father was accustomed to light. Here they sat in sleepy attitude, each awaiting his turn to be fed. Not in the least accommodating were they from the photographer's point of view, for generally when the camera was focused for the picture they would nod lower and lower, as children do at bedtime, till both were sound asleep in the warm sunshine. It was remarkable, however, to witness the effect of the mother's trill as she heralded the approach of something edible. In a flash both wrenlets on the wooden watch-tower were wide awake and on the tiptoe of expectancy.

Often do I remember trying to play foster-parent to young birds, and yet, with all my care and patience, I seldom succeeded. A week before, when I had held a large spider temptingly near the nestlings, they had crouched back in terror; but by this time they had certainly gained in worldly wisdom. I also had not been watching the wrens for the past two weeks without learning. I had seen the mother hop up and down an old stump, like a dog after a squirrel, till she would haul out a big grub. Digging into this bird storehouse with my knife, in a trice 
I collected half a dozen fine fat worms-a stock of provisions that would take the mother two hours to gather. Why are young birds so particular, anyhow? What difference does it make whether their dinner comes from the mother's mouth or from some kindly disposed neighbor?

"I'll just test the little wrens once more,". I said to myself, as I impaled two of the choicest grubs on a sharpened stick. It was impossible for me to announce the approach of this dinner with the soft little "Wink! Wink!" of the mother, but I patted both the sleepy birdies on the back and, rather hesitatingly, held up my offering. There was hardly room to doubt its acceptance. Mercy! Such a reaching and stretching! I could not divide up fast enough. Nor was one grub apiece sufficient. Quiet was not restored till each wrenlet had stored away two of the largest and fattest.

For the first time the parent wrens seemed to realize that I was actually of some use. The trying task of satisfying five growing appetites was lessened to some degree, and the busy parents took household affairs somewhat more easily the rest of the day.

The next time I saw the wren family all the young were scampering about in the bushes, following their parents hither and thither, earning their own livelihood, and rapidly learning for themselves the arts of woodcraft.

\section{THE WREN FAMILY}

The Wrens are all dull brown or gray birds and fine singers. They have long, slender bills and are generally found in low bushes and shrubbery where they hunt for worms and insects. In size they are from four to six inches in length. They are fidgety and inquisitive and may often be recognized by a tail that is tilted over the back. 


\section{Rearing a Wren Family}

House Wren (Troglodytes aëdon): Male and female, dark brown above, barred with a darker shade especially on wings and tail; under parts grayish-brown. Lives through eastern United States, where it may be found from the middle of April to October. Nest, a loose heap of sticks with a soft lining, in a bird-house or hollow tree. Eggs, six to ten, cream color, covered with red-brown spots.

The House Wren on the Pacific Coast is identical, but is called Parkman Wren. Vigors Wren is also similar but larger in size, and may be recognized by a whitish stripe over the eye. The Winter Wren is common in the East and West and is smaller in size, only four inches in length. Like the other wrens, it may be known by its plain brown clothes, fidgety movements and bright and lively song. 

THE WEATER OF THE WEST 




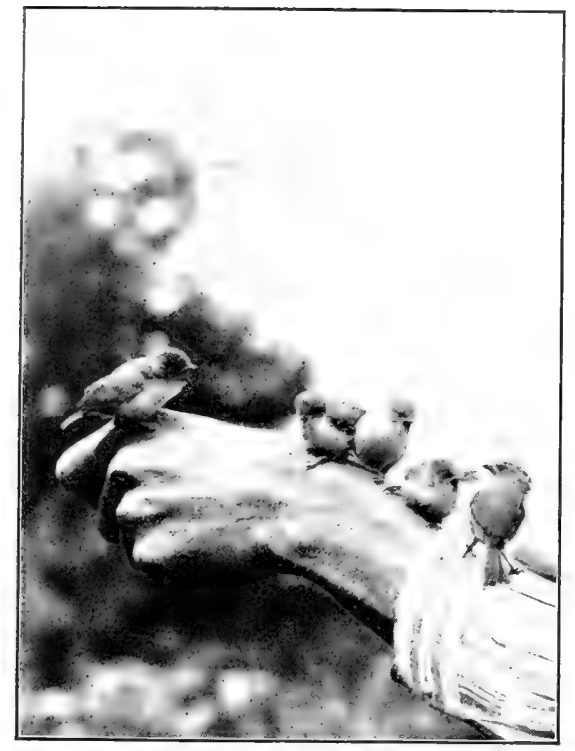

The parents lit wherever they found the children.

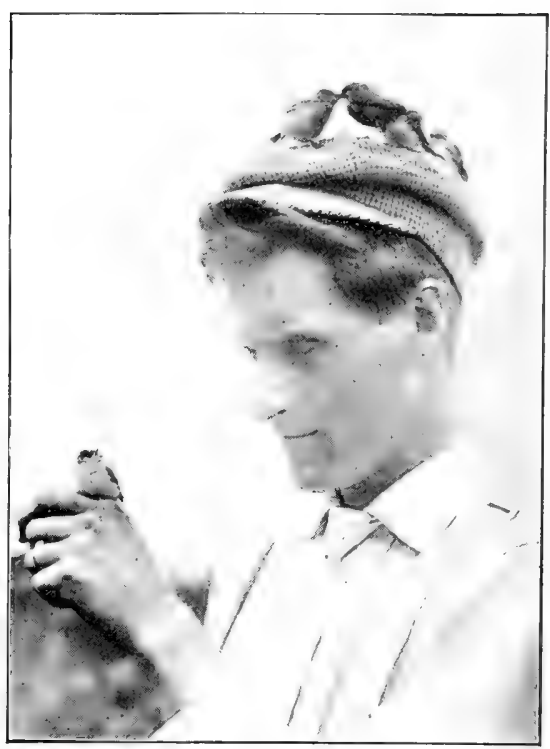

Bush-tit feeding young on top of cap.

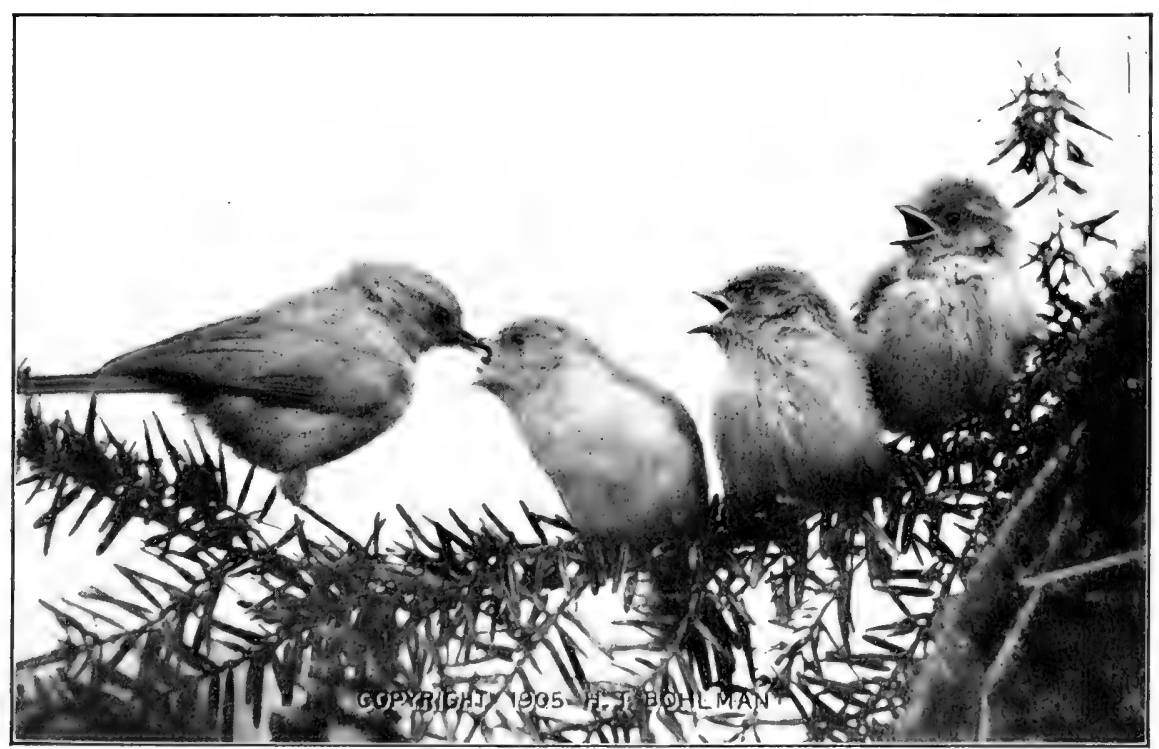




\section{$\mathrm{X}$}

\section{THE WEAVER OF THE WEST}

TAY on my back under the hemlock and marvelled 1 at the little mansion hanging in the glint of the warm June sun. Yes, a real bird mansion. Not open-roofed, for impudent passers-by to spy out family secrets; not set in a crotch, so that it could be tipped over or blown out, but carefully tied, cradlelike, to the drooping branches, where it could be rocked by the playing breezes.

It's not a small matter to get a site suited for a Bushtit's (Psaltriparus minimus) mansion. There should be one or two firm, upright twigs about which to weave the walls, a cross branch or two for rafters, and, if the house is to be modern, a little support for a porch or promenade. Contrary to our first rule for success, these little builders begin at the top and build down, first weaving the roof, leaving a round door, and then the hallway down to the main living-room. Each is the architect of his own home, and each is a born master builder.

Once I found a bush-tit's nest twenty inches long. The little weavers had started their home on a limb, and apparently it was not low enough to suit them, for they wove a fibrous strap ten inches long, and then swung their gourd-shaped nest to that, so it hung in a tussock of willow leaves.

I happened to find the nest in the hemlock when they 
were putting in the first spider-web cross-beams and supports for the roof, and only six feet from the ground, where I could see the whole process. In two days they had all the framework up and started with the furnishings. Each midget would return every few minutes with something new. Down into the bag he would dive, and it would shake and bulge for a moment, and then away he would dart for some more material. It took days to furnish the home. What downy draperies! What mosscovered walls, lichen-tinted in greens and browns! And most important of all, there was a thick bed of feathers, the resting-place of seven eggs of delicate whiteness.

You should have seen the way they put me in the same category with small boys, owls, and sparrow hawks. At first they didn't dare go near the nest for fear I'd see it. But, mercy! a titmouse might make twenty resolutions not to trust you, and the very next minute he'd throw himself and all his hopes right into your arms. There wasn't a fibre of suspicion in his little body, but his race had suffered so long that a good bit of caution had been embedded in his tiny brain. He tried to keep the family secret, but the minute he trusted me he told all he knew.

I stood almost within reach of the nest. The little lover looked me over from all sides. Then, as a final test, he popped right into the round door. He knew I would make a grab at him, nest and all. He was out in a twinkle. He looked amazed, for I didn't move. That was his test of friendship, and from that time on he gave me his confidence.

What implicit trust they placed in me! Why, I don't know. Had they forgotten the thousand wrongs the man- 
tribe had inflicted upon their kin? They had known me scarcely a week. I really believe the fluffy, gray bodies only remembered the kindnesses of our race, not the evils. Then, maybe, they had not forgotten the feathers I hung about on the limbs. But their happiness was my happiness. I rejoiced when the naked mites broke from the fragile shells. I had a private door all my own; a slit cut in the back wall where I could occasionally peek into the innermost depths, and then pin it carefully together again.

Anybody would fall in love with a bush-tit, even if he were not the chickadee's cousin. If it were not for his tail, the fluffy midget would be no larger than your thumb. He does not possess the aerial grace of a swallow, or even the nimbleness of a warbler. He bustles along in such a jerky way he often looks as if he would topple heels over head and go whirling to the ground like a tailless kite. But he is a skilled hunter. He skirmishes every tree and bush. He is not so successful a wing-shot as the flycatcher, but he has an eye that few birds can equal in stalking. He is no mean assistant of the gardener. He is not the kind that hoes a whole garden in a day, cutting off half the new tender shoots, but he's at work early and late, and he's constantly at it.

I kept run of bush-tit affairs for several days after the young had hatched. The father fed the nestlings as often as the mother. He generally paused a moment on the fern tops just below the nest, and by focusing our camera at this point we got his picture. Sometimes he would stop at the doorway with a look of inquiry that said, "What do you think of that for a dinner?" Occasionally I've 


\section{8}

\section{American Birds}

seen him swallow the morsel himself. He then justified his conscience by appearing too timid to enter the door. The real drama of life began when the youngsters were fluttering, full-grown, vigorous, impatient to get one glimpse at the great outside from where the mother and father came so often with morsels.

One morning I saw a pair of bright eyes pushed right through the fibrous wall at my own observation door. An ambitious youngster had seen the wall open and close too often not to know there was a way. He had worked it open, and it was just where he could sit and look longingly out.

The time had come; we had watched and waited two weeks for this day. The minute one nestling took the idea into his head to get out into the sunshine, it spread like contagion among the whole household. They came not in singles, but in battalions! If we'd had a dozen eyes we couldn't have kept track of them. We put several back on a twig beside the nest, where they sat fluffing in the warm sunshine, enjoying their first outing, and awaiting their turns to be fed rather impatiently.

Each titmouse had a tiny tinkle for a voice that was almost as hard to hear as the whisper of the flowers. I had to strain my ears to catch it more than a few feet away. One nestling flew over into the deep ferns, but I might have searched till doomsday for him. But the mother knew where he was the instant she returned. Another flew down into our camera box, and I shut the lid to see if the mother would find him. She lit right on the box with a billsome morsel, and looked so uneasy that I had to let her in. It looked to me like wireless telegra- 


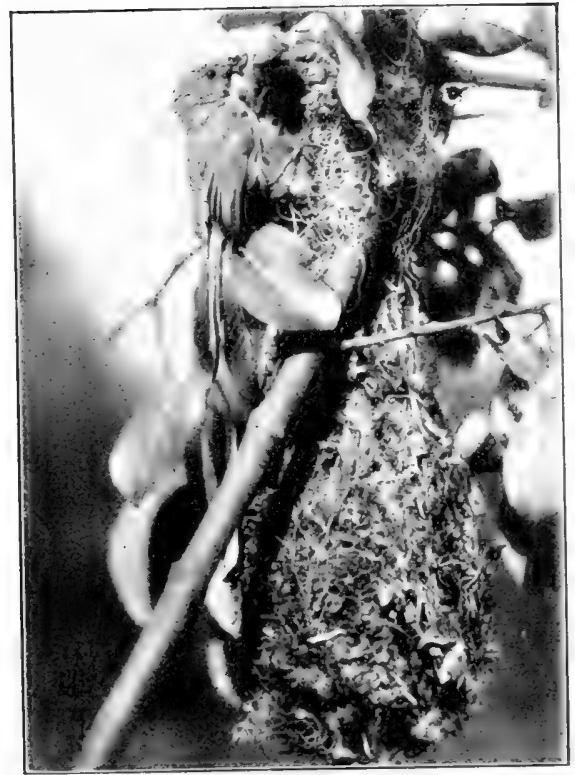

linhlitit at door of long langing nest

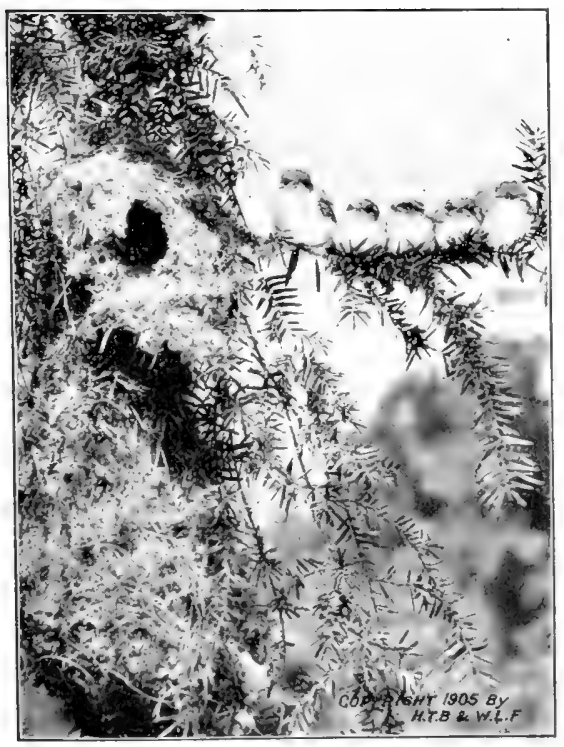

Young Push-tits beside long pendent nest.

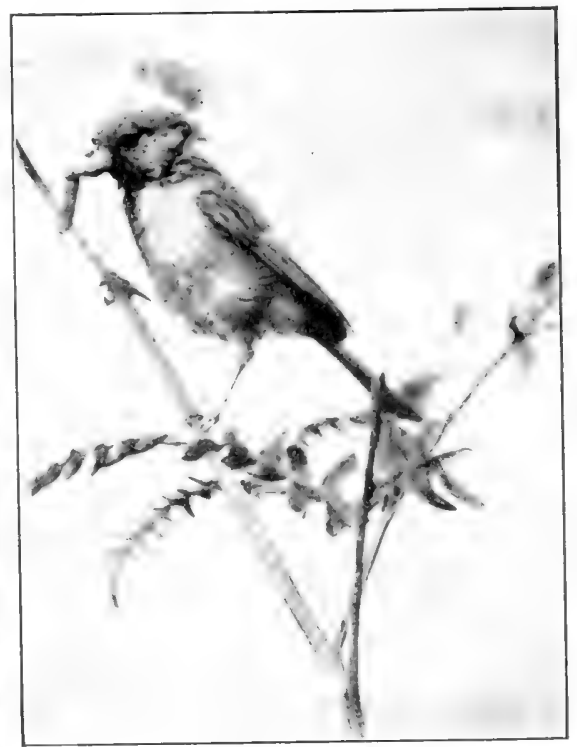

Male Push-tit with green cutworm for young. 

phy. Maybe the birds had a system of long-distance communication even before man called through a trumpet, and ages before he ever shipped his thoughts by wire.

We were fairly overrun with titmice. They climbed into our camera and clung to our clothes as easily as a fly walks up a wall. They perched on our fingers and our heads, and the parents lit wherever they found the children. Some fairy always told the mother where to go, as she came again and again with green cutworms that seemed as large as the head of one of her babies.

Birds differ only in size and dress to some people, but to one who has studied long and carefully at the homes of the different species each feathered creature has a real character of its own. What does a cut-and-dried catalogued description mean? "Name, Psaltriparus minimus (Bush-tit). Nest in hemlock tree six feet from the ground. Identity, positive. Eggs, seven, pure white." This is all right for a city directory, and is almost as interesting. Think of labelling your friends in this way! You don't know a bush-tit any more when you have found him with a field-glass and identified him in your bird manual than you do a man when you are introduced to him and shove his card in your pocket. Each bird has a real individuality. Each is different in character and disposition from all others. I knew the bush-tit and chickadee were cousins before I ever heard of the Parade family. They may not look much alike in dress, but aren't they identical in disposition? They are merry because they can't look on the dark side of things. Let to-morrow take care of itself; they live for to-day.

I've watched the young birds of many species where 
the parents care for them a week or so after they leave the nest till they are able to hunt a living for themselves; then the family scatters and loses identity in the great world of feathers. Not so with the bush-tits: they hunt, feed, and sleep together, winter as well as summer. Such little talkers! They titter as much as they hunt and eat, and that is all day long. When you meet them in the woodland it sounds like a fairy's wedding march.

I found the little family in the hemlock tree even more interesting after they all learned to fly. Several times I saw them about the patch of woods. One day I stood watching the flock of midgets in an alder copse. Each youngster had learned to keep up a constant "Tsre-e! Tsre-e! Tsit! Tsre-e!" as if always saying something, but I do not think this gossip was as much for the sake of the conversation as merely to keep the whole flock constantly together. While I was watching, three or four of the little fellows were within a few feet of me. One of the parents in the next tree began a shrill, quavering whistle, and instantly it was taken up by every one of the band. The two tiny birds near me, as well as every one of the others, froze to their perches. Had I not known, I couldn't have told just where the whistle was coming from, it sounded so scattering, like the elusive, grating call of the cicada. Then I saw a hawk sweeping slowly overhead, and the confusing chorus lasted as long as the hawk was in sight; nor did one of the little bush-tits seem to move a feather, but just sit and trill in perfect unison. It served as a unique method of protection; the whole flock had learned to act as a unit. It would have been hard for an enemy to tell where a single bird was, the 
alarm note was so deceiving. They were so motionless and their clothing harmonized so perfectly with the shadows of the foliage.

Millions of destructive insects lay their eggs, live and multiply in the buds and bark of trees, and it seems the bush-tit's life-work to keep this horde in check. After the little family left their home I never found them quiet for a minute. When they took possession of a tree they took it by storm. It looked as if it had suddenly grown wings and every limb was alive. They turned every leaf, looked into every cranny, and scratched up the moss and lichens. They hung by their toes to peek into every bud; they swung around the branches to pry into every crack; then, in a few moments, they tilted off to the next tree to continue the hunt.

\section{THE BUSH-TIT FAMILY}

The Bush-tits are the dwarfs of the chickadee family. They are four inches in length and half of this is tail. They have very short bills and tiny gray bodies. The bush-tits are exclusively western, and are remarkable nest builders. They live on insect eggs, scale, plant-lice, caterpillars, and other injurious insects.

Bush-tit (Psaltriparus minimus): Male and female, uniform gray in color, darker above and lighter below; scarcely larger than a hummingbird in size, but with a tail as long as body. Found on the Pacific Coast. Nests in April and May. Nest, hanging and gourd-shaped, with small hole near the top. Eggs, five to nine, and pure white. 

JIMMY THE BUTCHER-BIRD 
. 


\section{$\mathrm{XI}$ \\ JIMMY THE BUTCHER-BIRD}

7 HE first time I saw Jimmy he was doubled up in a 1 fluffy ball with his head under his wing. For a bed he had taken a eucalyptus limb that hung on the back porch. He had been brought in with another nestling by a small boy, who said that the mother had "died of a cat." There was a question at the time as to whether this was the real cause of her taking-off, but the fact remained that the bantlings were in danger of starvation. With two orphans on her hands, there was nothing left for our neighbor to do but to adopt them. A little fresh meat seemed to revive the two bobtailed youngsters, but the smaller of the two was not long for this world, and in a few days one young Butcher-bird (Lanius ludiovicianus gambeli) was left.

Yes, a butcher-bird for a pet. Might as well adopt a cannibal or become a foreign missionary, one of our friends thought. But helplessness always arouses pity, and some of us like a bird merely because he is a bird.

Some one has said that man's interest in birds lies in the fact that we were birds ourselves before we reached the human stage. An angel is a child with wings. How much bird actions are like human actions! They frolic and they toil. What other animal approaches nearer to man as a home builder and housekeeper than the bird?

And, after all, this young orphan butcher-bird could 
hardly be blamed for the sins of his ancestors, even though his own parents had likely murdered a caged canary that had lived not far away. He was the son of a murderer, but by adoption into a respectable family who could tell but that this fledgling might develop into a bird of good qualities? We were of the opinion that a shrike had no good qualities, that he was a butcher pure and simple, and killed his own kind for the pure taste of blood and brains. In fact, the first impression I ever got of a shrike or butcher-bird was when I was called out to the back porch and saw our tame canary lying headless in the bottom of the cage.

But even though the shrike is the enemy of the small birds, they do not seem to realize that he is dangerous. I have often seen birds pay no more attention to a shrike than to a robin. Perhaps he does not attack the birds in the open, where they can fly and dodge and get away. I think the shrike likes caged birds best, those he can scare and catch through the bars and tear to pieces as the victim is held by the wires.

The shrike is called the butcher-bird from its habit of hanging its meat on a hook or in a crotch. He is much the same size and form as the blue jay. He has a grayish coat. I generally see him flying about the fields and occasionally lighting in the stubble, where he picks up crickets, grasshoppers, and mice. The habit of the shrike in impaling its food on thorns or fastening it in crotches comes as a necessity to the bird in tearing its food. It has a hooked bill, but is not equipped like the hawks and owls with talons to hold its food. Although this bird undoubtedly kills some small songsters, we wanted to find out whether 


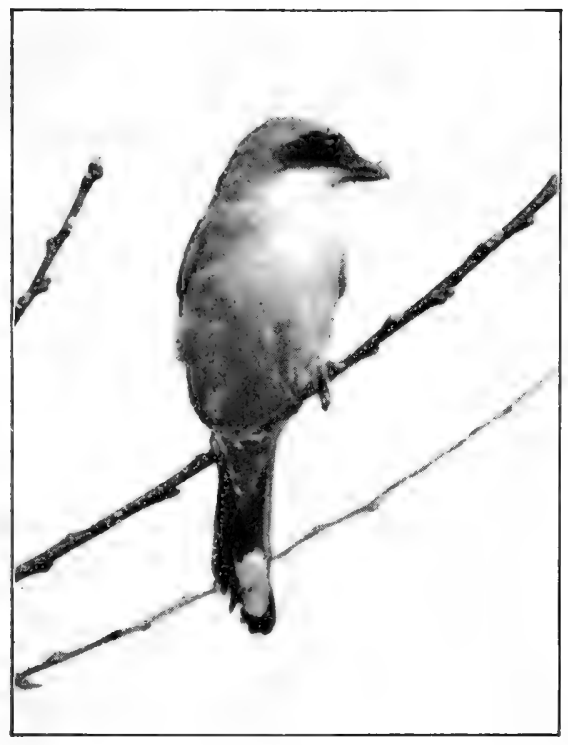

Jimmy.

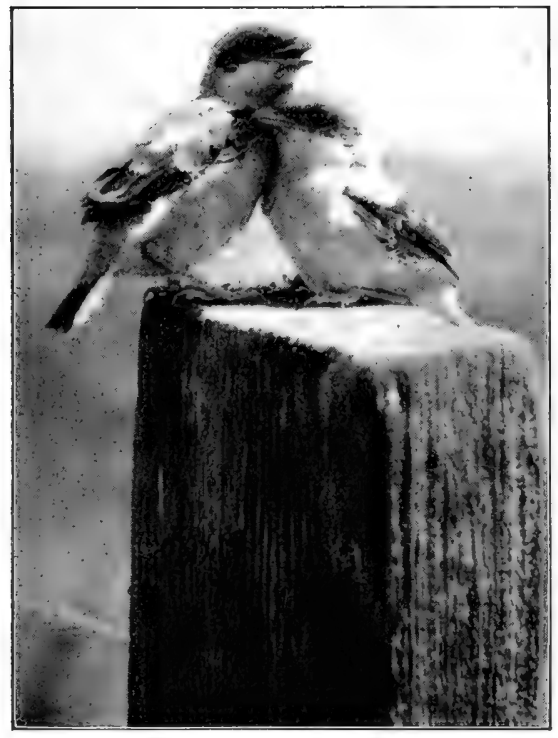

Pair of young Shrikes or Butcher-birds.

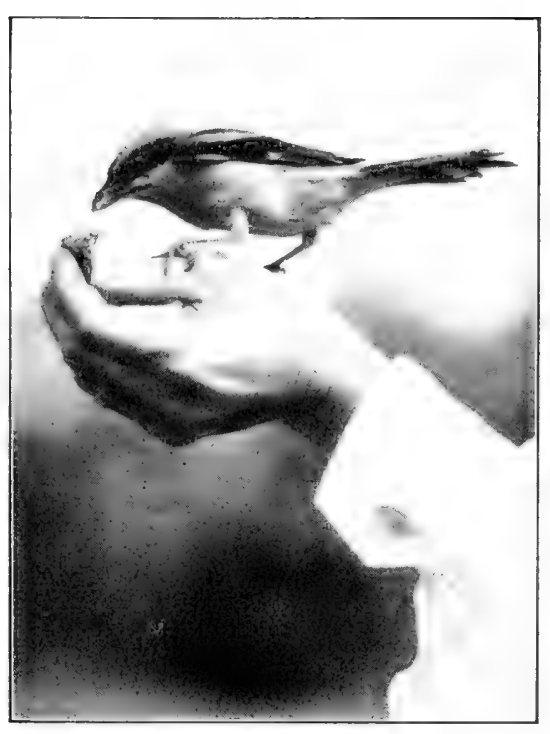

Jimmy eating from the hand of his mistress.

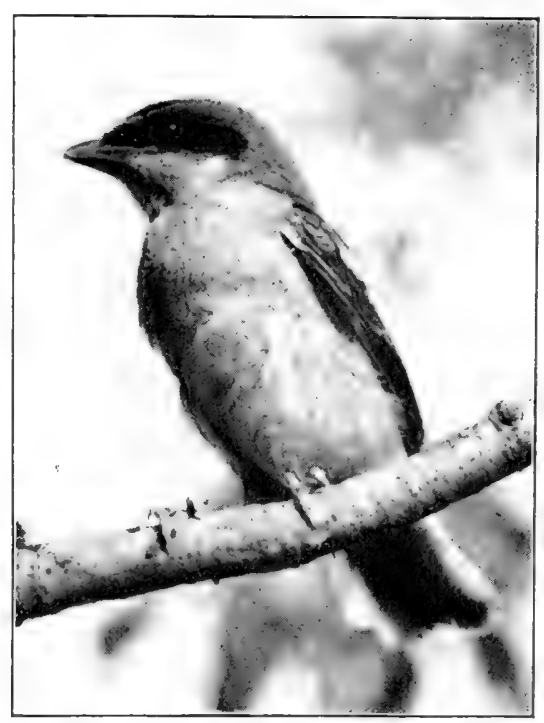

He often perched in the pear tree. 


\section{Jimmy the Butcher-bird}

under different circumstances he would change his barbarous traits.

Can a wild bird be civilized? Can he retain his freedom and yet put off his bad habits? When he begins to hunt his own food, will he know that it is right to hunt beetles, grasshoppers, and mice, but against the law to kill goldfinches?

Jimmy was given the freedom of the back porch. This was a large apartment, and was well screened. Some branches were hung up to make the place look as woodsy as possible, and a special table was built for the new arrival. In two or three weeks he was able to fly quite well, and it was decided to give him the freedom of the back yard. It was the real nature of the bird that we wanted to study, the wild bird under civilized circumstances, but not in a cage.

It did not take Jimmy long to make friends and to know his mistress. He was awake and squealing at daylight. He fluttered at the window, and the minute the door opened he was in the kitchen and perched on the shoulder or arm of his mistress, begging to be fed. There was no doubt as to his preference; he wanted fresh meat. When the door of the back porch was opened and Jimmy was invited to go out into the yard and learn to find his own breakfast, he accepted the invitation with eagerness. $\mathrm{He}$ poked around through the rose-bushes and along the fence more from curiosity than with the idea of getting something to eat. He often perched in the pear tree. Then, when he was hungry, he hopped back to the porch, for he knew the table was always set there.

Jimmy was lazy when it came to hunting his own 
living. The fact that he had a free lunch-counter at his back porch home he did not forget. That seemed to be the binding link. He would go about the yard and up into the trees, and he got to wandering farther and farther; but he would always come back several times during the day for food. He knew his name as well as a person does, and would come immediately if he were within calling distance.

As Jimmy grew older he developed into a fine-looking bird. His coat was a slate-gray above and a dull whitish color below. He soon developed remarkable likes and dislikes. I would hardly have believed that a bird could have shown so much knowledge had I not seen it myself. We are too apt to think there is little real intelligence in the bird brain. I have often wished I could fathom the thoughts that Jimmy had as he sat in his master's room for hours at a time and looked out of the window when it was raining, or when he hopped about the kitchen, picking up and prying into things, or when he stopped to look his mistress in the eye and chuckle with a side turn of his head. He had the range of the house and the range of the outdoors, yet he often preferred to stay indoors when he took human company to bird company. He knew his home as well as the dog did. But Jimmy didn't like dogs or cats.

When he had the freedom of the house he liked to tease, and his teasing turned to a pet mockingbird that was kept in a cage. At first Jimmy would sit on the table and watch. Then he took to flying on the top of the cage, and this worried the mocker, who didn't want any one on the cage above his head. But it pleased Jimmy, and he 
would hop back and forth in a threatening way. This happened several times, till one day the mocker had his chance; I think he had been waiting for it. Jimmy was on the side of the cage with his feet hooked in the wires, when the mocker suddenly grabbed him by the toe and gave it such a sharp pull that Jimmy squealed in pain. It was a pure case of revenge, and the mocker enjoyed it. It gave a good insight as to how quick Jimmy could learn, for he kept off the cage after that, and did not tease the mockingbird.

Gradually Jimmy's freedom of the house was taken from him. He couldn't be trusted to leave anything in order. He knocked things off the bureau, broke a painted china cup, and he always wanted to taste out of every dish on the table. He stuck his feet in a dish of jam, and then tracked it across the table. And how he liked butter! He dipped right in the instant he saw butter, and that was his first thought when the pantry door was open.

One day when the kitchen was closed Jimmy found the window of the east room upstairs open and in he went, and soon appeared in the dining-room, helping himself. After that the window was kept shut, but Jimmy would go anyway and peck on the glass till he was let in. His master often sat there, and that became Jimmy's favorite room. All during the winter on rainy days he liked to stay in that room. The window looked directly out to the east over a waste of weeds and sage-brush. This was Jimmy's hunting-ground; he always went out that way when he wanted to hunt, for that was the only uncultivated tract about the house. That was the place he hunted grasshoppers and crickets. His favorite perch was the 
back of a chair near the window, where he could look out over the slope, and here he would sit for an hour at a time, as if thinking. And how do we know but that he was going over many of his hunts and hairbreadth escapes and thinking of the springtime that was coming and the new experiences it would bring?

Out in front of the house was a concrete basin where the water-lilies grew. The lily-pads were large enough to support a bird, and the linnets and goldfinches used them for bath-tubs. I think the birds came for a mile around to get water here, for there was hardly a time during the hot days when some visitors did not come either to wash or to drink. Jimmy often watched the performance and seemed interested, but he knew better than to prey upon birds. His home training had gone deep enough for that, and he had been civilized to that extent.

Jimmy didn't bathe very often himself, but when he did he simply soaked himself till he couldn't fly. For some reason he preferred the irrigating ditch; there he had plenty of running water. Perhaps he thought the basin where every tramp bird bathed was not clean enough. He selected a shallow place and waded in to his middle; then he began bobbing and throwing water, and he kept it up till he was so tired and heavy he could hardly crawl out.

When it came to dealing with other people, Jimmy had many interesting experiences. He was bold and fearless, no matter whether he knew the person or not. One day when Jimmy had been gone several hours he was brought home by one of the neighbors. A carpenter was at work on the top of his house, when Jimmy, apparently in fun, 
had swooped down and lit on his shoulder and began screeching in his ear. The workman was so astonished that he almost fell from his position when he felt this strange bird fluttering about his head; he dodged as if he were trying to get rid of a swarm of bees. He didn't know whether to fight or not. But he was soon assured that the bird was only playing.

For some reason Jimmy did not like the gardener. His mistress thought it was because the man wore such ragged clothes. She said he always took to people who were dressed up, and was friendly in every way, but the minute a workingman came about Jimmy would squall and peck and show his anger. When the gardener was hoeing, Jimmy would fly down at his feet and get in the way, or he would hop along in front of the wheelbarrow or ride on the front, squealing his disapproval. Twice he lit on the shoulder of the gardener and bit him in the neck till the blood came. This was carrying his opinions to such an extent that his mistress caught him and clipped the little hook on his bill. This served as a sort of a muzzle, so he could not bite so hard.

The instinct was strong in Jimmy to hang his food on a nail or in a crack so he could tear it to pieces. He often brought in insects from the field, and would always fly direct to the hand of his mistress, because she so often held his meat in her hand for him to eat. He would light on her shoulder with a screech and a side turn of his head that said, "Hold this for me, quick, till I eat it!" And if she didn't, he showed great impatience. But this habit of Jimmy's was distasteful at times, for he brought in a variety of things from dead mice to crickets, worms, and 
beetles. One day when a fashionably-dressed lady was being entertained on the front porch Jimmy suddenly appeared and lit on her shoulder with a very large beetle. The reception he got surprised him, for a bird thrusting a big, ugly beetle in her face was too much for the lady, and she threw up her hands in horror and fled, while Jimmy sat looking in amazement.

The wicker-backed rocking-chair on the front porch was a favorite of Jimmy's, for he could fasten his food in the cracks of it. One day his mistress found a mouse that he had left there, very likely with the intention of calling for it when he got hungry. By watching the various kinds of food that Jimmy brought in, we readily estimated that his hunts were of much more good than harm. Even the wild shrike that kills a small bird occasionally kills more than enough harmful insects to make up for its destruction.

As the winter passed and spring wore on, Jimmy extended his visits. He must have looked and hunted farther away, for often he would be gone for half a day at a time. But he always returned to the eucalyptus bough on the back porch, and the door was always open for him and closed when he was in bed. Then one day in March he did not return. But he got back next morning about ten o'clock, and came pecking and crying at the window. He seemed overjoyed to get back, but, after staying about for a while, he got restless. It was evident that there was an influence somewhere out beyond the sage-brush that was stronger than his home life. Something else was calling him. It was only a matter of time till he would cease to sleep on the porch. 


\section{Jimmy the Butcher-bird}

About two weeks later Jimmy was seen for the last time. There were two shrikes out in the low oaks beyond the irrigating ditch. One came sweeping across from the hill, flapping his short wings and screeching his greetings in butcher-bird tongue. He paused just long enough on the fence to see that his companion had disappeared. With a loud squawk Jimmy turned back to find her, for that was his new mistress.

\section{THE SHRIKE OR BUTCHER-BIRD FAMILY}

The Shrikes may be recognized by the powerful head and neck and the hooked bill. Length, about nine inches. Bluish-gray in color. They are bold and fearless and feed on insects, mice, and small birds, which they impale on thorns and sharp twigs.

White-rumped Shrike (Lanius ludovicianus excubitorides), Butcherbird: Male and female, upper parts pale ashy-gray; narrow black stripe across forehead through eye; under parts and rump, white; wings and tail, black with white markings. Found in middle and eastern North America, where it nests in hedges and thorn-trees. Eggs, four to six, grayish, covered with brown spots.

The Northern Shrike is very similar but is seen only from November to April as a roving winter resident.

California Shrike (Lanius ludovicianus gambeli): Pacific Coast form, identical with White-rumped Shrike. 

THE WARBLER AND HIS WAYS 



\section{XII}

\section{THE WARBLER AND HIS WAYS}

URING the warm days of June, I often frequent a woody retreat above the old mill-dam on Fulton Creek. The water gurgles among the gray rocks and glides past a clump of firs and maples. Star-flowers gleam from the darker places of shade, white anemones are scattered in the green of the grass blades and ferns, and Linnæan bells overhang the moss-covered logs.

As one sits here in the midst of the woods, the chords of every sense are stretched. The nostrils sniff the scent of the fir boughs tipped with their new growth of lighter green. The eye catches the cautious movements of furry and feathered creatures. The heart beats in tune with the forest pulse.

One day as I lay idling in this favorite haunt a shadow, caught in the net of sunbeams, spread under the maple. A Black-throated Gray Warbler (Dendroica nigrescens) fidgeted on the limb above with a straw in her bill. This was pleasing. I had searched the locality for years, trying to find the home of this shy bird, and here was a piece of evidence thrust squarely in my face.

The site of the nest was twelve feet from the ground in the top of a sapling. A week and a half later I parted the branches and found a cup of grasses, feather-lined, nestled in the fork of the fir. There lay four eggs of a pinkish tinge, touched with dots of brown. 
The chief source of satisfaction in a camera study of bird life comes not in the odd-time chances of observation, but in a continued period of leisure when one may spend his entire time about bird homes just as he takes a week's vacation at the sea-shore. One cannot take a camera, no matter how expensive it is, and snap off good bird pictures during the spare moments of a busy day. He might, however, fill half a dozen note-books with valuable odd-time observations. To be sure, the joy of nature comes to the amateur, not to the professional, but to be a successful amateur bird-photographer one has fairly to make a business of lying in wait for his subjects hour after hour, day by day, and maybe week after week. The reward of real success comes not in mere acquaintanceship with some feathered bit of flying life, but in real friendship; there cannot be the formality of a society call, but one should, by frequent visits, be well enough acquainted to drop in at any time with his camera without interfering with the daily affairs of family life.

The real value of photography is that it records the truth. The person who photographs birds successfully has to study his subjects long and carefully. He is likely, therefore, to get a good set of notes, and not to be compelled to complete his observations when he is seated in the comfortable chair of his study. Of course, in the study of art, we may try to improve on nature, but in nature study truth is the chief thing. We must understand that a beast or bird is interesting for its own wild sake.

Of course it showed a pure lack of discretion to try to picture the home of such a shy warbler during the days of 

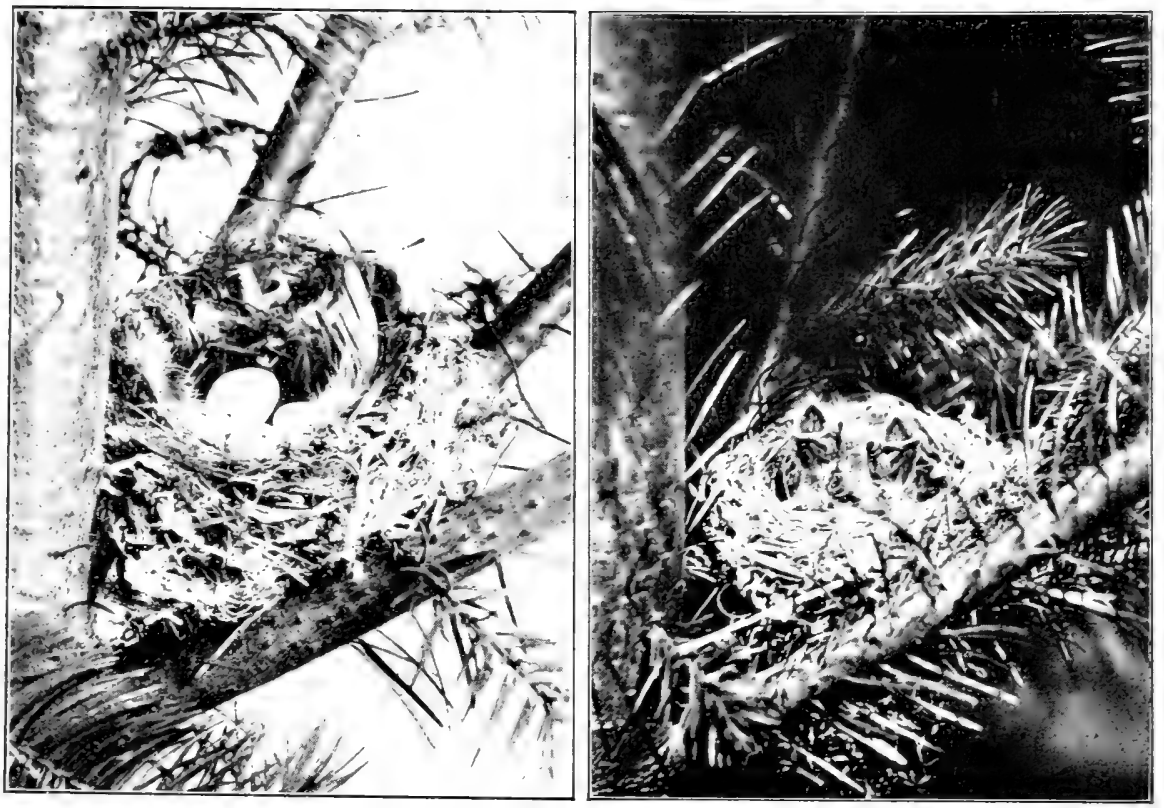

Dew and exw of Hawh threaterd liray Warbler.

[iso smail neotlings.

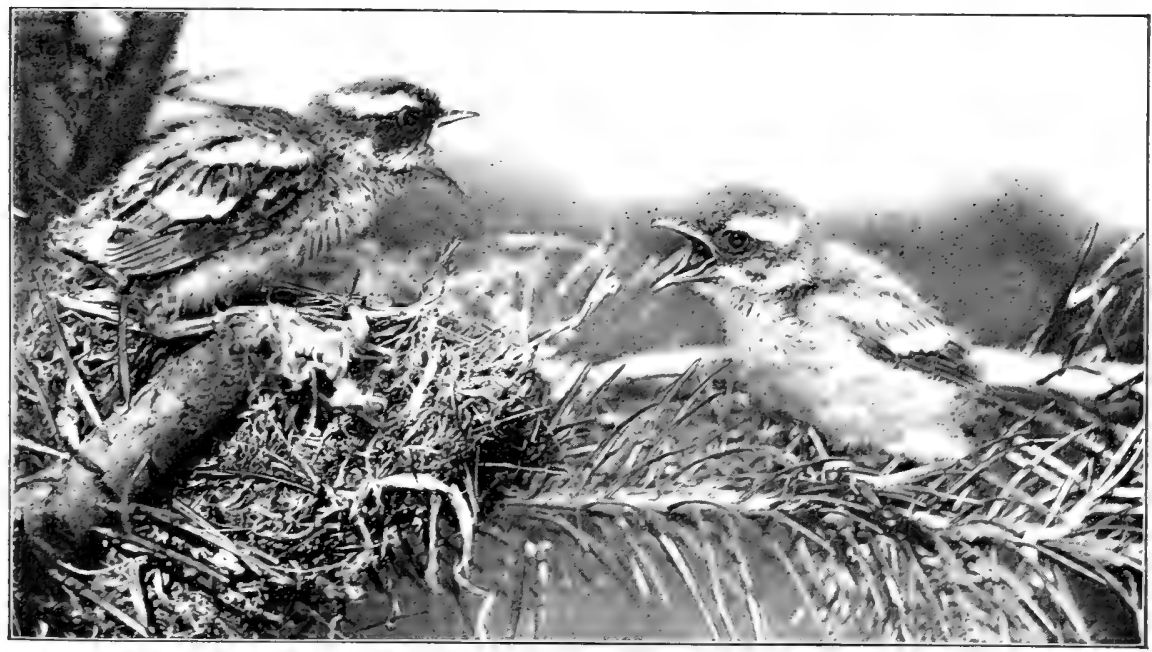

bisputing while mother is away. 

incubation, but I half believe the feathered owners would have overlooked this had it not been for the pair of blue jays that buccaneered that patch of fir. While we were getting a picture I saw them eyeing us curiously, but they slunk away among the dark firs squawking jay-talk about something I didn't understand. Two days later we skirted the clump to see if the warblers had been too severely shocked by the camera. In an instant I translated every syllable of what that pair of blue pirates had squawked. The scattered remnants of the nest and the broken bits of shell told all.

These gray warblers, however much they were upset by the camera-fiend and blue jay raid, were not to be undone. They actually went to housekeeping again within forty yards of the old home site. The new nest was placed in a fir sapling very like the first, but better hidden from marauding blue jays. It was far better suited to the photographer. Just at the side of the new site was the sawed-off stump of an old fir upon which we climbed and aimed the camera straight into the nest. There, instead of four, were only two small nestlings. They stretched their skinny necks and opened wide their yellowlined mouths in unmistakable hunger.

The moment the mother returned and found us so dangerously near her brood she was scared almost out of her senses. She fell from the top of the tree in a fluttering fit. She caught quivering on the limb a foot from my hand. Involuntarily I reached to help her. Poor thing! She couldn't hold on, but slipped through the branches and clutched my shoe. I never saw such an exaggerated case of the chills, or heard such a pitiful high- 
pitched note of pain. I stooped to see what ailed her. What, both wings broken and unable to hold with her claws! She wavered like an autumn leaf to the ground. I leaped down, but she had limped under a bush and suddenly got well. Of course, I knew she was tricking me.

The next day my heart was hardened against all her alluring ways and her crocodile tears. She played her best, but the minute she failed to win I got a furious berating. It was no begging note now. She perched over my head and called me every name in the warbler vocabulary. Then she saw that we were actually shoving that cyclopian monster right at her children. "Fly! Fly for your lives!" she screamed in desperation. Both the scanty-feathered, bobtailed youngsters jumped blindly out of the nest into the bushes below. The mother outdid all previous performances. She simply doubled and twisted in agonized death spasms. But, not to be fooled, I kept an eye on one nestling and soon replaced him in the nest where he belonged. Nature always hides such creatures by the simple wave of her wand. I've seen a flock of half a dozen grouse flutter up into a fir and disappear to my eyes as mysteriously as fog in the sunshine.

This fidgety bit of featherhood is called the blackthroated gray warbler, but it's only the male that has a black throat. $\mathrm{He}$ is not the whole species. His wife wears a white cravat and she, to my thinking, is a deal more important in warbler affairs. Mr. Warbler seemed to be kept away from home the greater part of the day when the children were crying for food.

The first day I really met the gentleman face to face we were trying to get a photograph of the mother as 
she came home to feed. She had got quite used to the camera. We had it levelled point-blank at the nest, only a yard distant. A gray figure came flitting over the treetop and planted himself on the limb right beside his home. He carried a green cutworm in his mouth. No sooner had he squatted on his accustomed perch than he caught sight of the camera. With an astonished chirp he dropped his worm, turned a back somersault, and all I saw was a streak of gray curving up over the pointed firs. I doubt if he lit or felt any degree of safety till he reached the opposite bank of the river.

We met his lordship again the following day. The mother was doing her best to lure us from the nest by her cunning tricks. Every visit we had made she kept practising the same old game. Just as she was putting on a few extra touches of agony I saw a glint of gray. The father darted at the deceiving mother. I never saw such a case of wife-beating. Maybe she deserved it. I don't know whether he blamed her for my presence and interference, or whether he wanted all her time and attention devoted to the care of the children. She didn't practise deceit any more.

I could not tell one nestling from the other. As I sat watching the mother the questions often arose in my mind: Does she recognize one child from the other? Does she feed them in turn, or does she poke the food down the first open mouth she sees? Here is a good chance to experiment I thought. So with a good supply of $5 \times 7$ plates we watched and photographed from early in the morning till late in the afternoon for three days. At the end of that time we had eight pictures, or rather four 
pairs, each of which was taken in the same order as the mother fed her young.

The warblers foraged the firs for insects of all sizes and colors. The mother often brought in green cutworms, which she rolled through her bill as a housewife runs washing through a wringer, either to kill the creature or to be sure it was soft and billsome. This looked like a waste of time to me. The digestive organs of those bobtailed bantlings seemed equal to almost any insect I had ever seen.

In the days I spent about the nest I never saw the time when both the bairns were not in a starving mood, regardless of the amount of dinner they had just swallowed. The flutter of wings seemed to touch the button that opened their mouths. At the slightest sound I've often seen disputes arise while the mother was away. "I'll take the next," said one. "I guess you'll not!" screamed the other. The mother paid no more attention to their quarrels and entreaties than to the ceaseless gurgle of the water. How could she? I don't believe she ever caught sight of her children when their mouths were not open. The fact that the mother fed them impartially appealed in no way to their sense of justice. The one that got the meal quivered his wings in ecstasy, while the other always protested at the top of his voice.

The first pair of pictures in the series was taken while the young were still in the nest. The mother fed the nearest nestling. Changing the plate and adjusting the camera again I had to wait only three minutes. The bairn at the edge of the nest surely had the advantage of position, but what was position? For all his begging the 


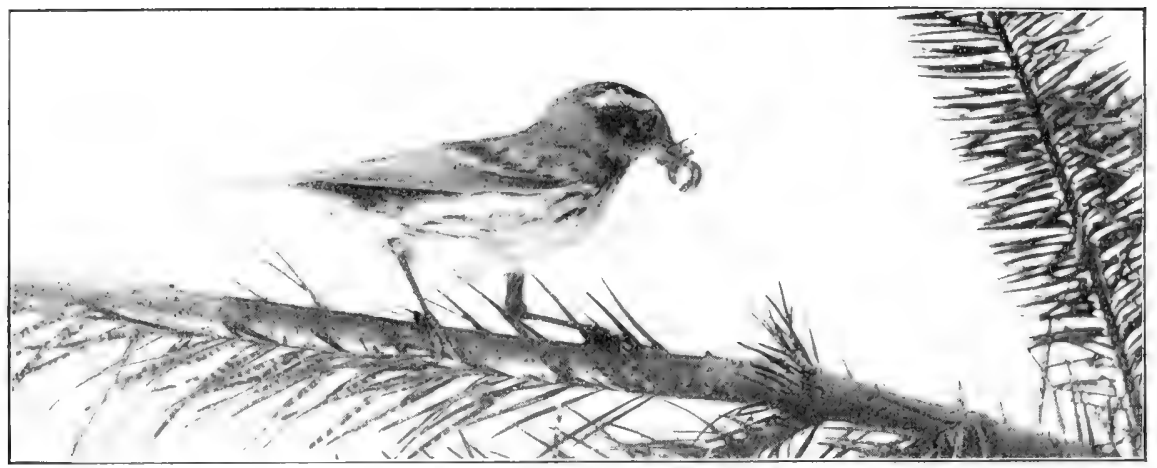

The mother aften brought in sreen cutworms.

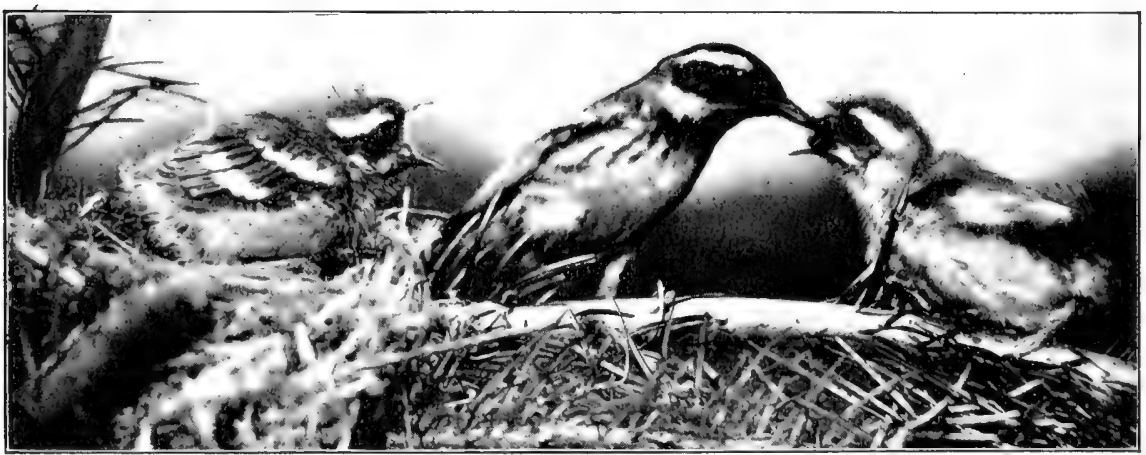

The uray mother rewarded him with a mouthful.

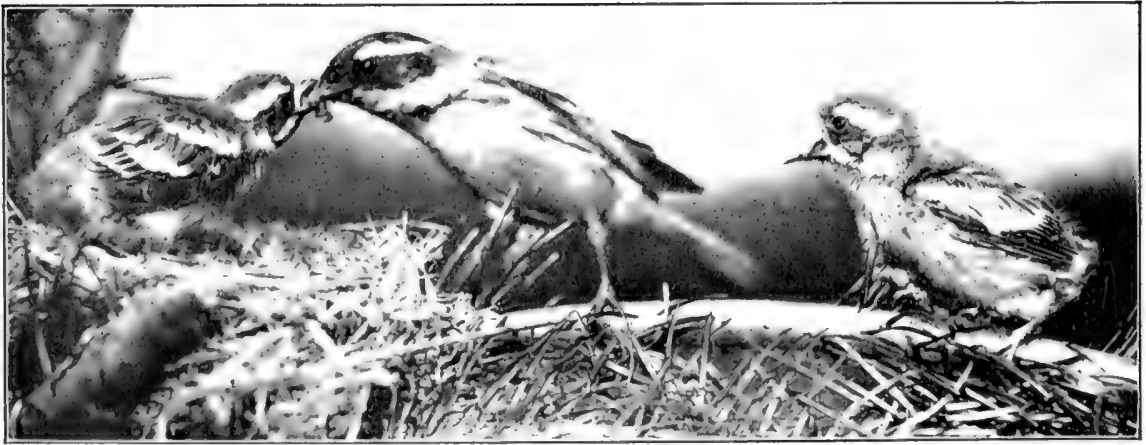

She did not forget the hungry, more timid fledgling in the nest. 


\section{The Warbler and His Ways}

nearest got a knock on the ear that sent him bawling, while his brother gulped down a fat spider.

Soon after one of the bantlings hopped out on the limb, and the gray mother rewarded him with a mouthful that fairly made his eyes bulge. On her return she did not forget the hungry, more timid fledgling in the nest.

Again I tried the experiment of having the mother light between her clamoring children. First the right one received a toothsome morsel, notwithstanding the impatient exclamations of the chick on the left. Soon after the hungry bairn on the left got a juicy bite, in spite of the loud appeals from the right.

"This way I'll fool the mother," I thought, as I perched both bantlings on a small limb where they could be fed only from the right. This looked good to the first little chick, for he seemed to reason that when he opened his mouth his mother could not resist his pleadings. He reasoned rightly the first time. On the second appearance of his mother position did not count for much; it was his brother's turn.

Later in the day I watched the gray warbler coax her two children from the fir into the thick protecting bushes below. With the keen sense of bird motherhood she led them on, and they followed out into the world of bird experience.

\section{THE WOOD WARBLER FAMILY}

This is one of the largest families of North American birds. The Warblers are five inches or less in length. They are all migratory; they live almost entirely on insects. The bill is narrow and, like the feet, 
delicately formed. The bird is often beautifully colored, quick and active, flitting incessantly among the leaves.

Yellow Warbler (Dendroica astiva), Summer Yellow-bird: Male, above, rich yellow, brightening on rump; breast and under parts golden yellow; breast streaked with brown. Female, less brightly colored. Our commonest warbler living throughout North America at large, arriving from the South in May and remaining till September. Nest, a small, well-rounded cup in the fork of a bush or tree. Eggs, four or five, grayish-white, spotted with lilac or red-brown.

Some of the other common warblers that may be found living throughout the eastern states are the Black and White Warbler, striped above with the colors for which it is named, and having a white breast. Blue-winged Warbler, with slatish-blue wings and white bars, forehead and under parts yellow, with dark stripe through eye. Nashville Warbler, yellow below, above, olive-green, brightening on rump and shoulders, slate-gray head and neck. Parula Warbler, above slate-blue, chin and throat yellow, wings brownish with two white bars, white belly with red-brown band across breast. Myrtle Warbler, slate color, striped and streaked with black; crown, sides of breast and rump yellow, white throat, upper breast black and whitish below, white bars on wings and white spots on tail. Chestnut-sided Warbler, throat and breast white with chestnut stripe extending down sides, top of head yellow, black stripe running through eye and black spot in front. Black-poll Warbler, black cap, upper parts striped with black, olive, and gray, breast white with black streaks, white spots on outer tail feathers. Blackburnian Warbler, crown black with orange patch, black wings and tail with white markings, throat brilliant yellow, rest of under parts pale yellowish. Blackthroated Green Warbler, crown and back olive-yellow, sides of head clear yellow, throat and upper breast black and black stripe down sides, lower parts yellowish-white, wings and tail brownish with white wingbars. American Redstart, upper parts blue-black, white belly, sides of body and lining of wings orange, tail feathers half orange and half black.

On the Pacific Coast the Black-throated Gray Warbler has the head, throat, and chest black except for white streaks on side of head and along throat; yellow dot in front of eye; breast and belly pure white; 


\section{The Warbler and His Ways}

back gray streaked with black; wings with two white bars. Audubon Warbler is the western representative of the Myrtle Warbler and is marked similarly, except that the throat is yellow. Lutescent Warbler, upper parts dull olive-green, brighter on rump; under parts bright greenish yellow; crown with dull orange patch concealed by olive tips of feathers. 
- 
KINGFISHERS 



\section{XIII}

\section{KINGFISHERS}

T'LL clothe and equip each of my creatures for a 1 special work, and give him some particular thing to do," says Nature. " I'll give the hummingbird a long bill to suck honey from the flower-cups. I'll give the nighthawk a big mouth to catch flies. I'll give the grosbeak a large, powerful bill to crack seeds. I'll give the snipe long legs to wade in the mud and water and find his food. I'll give the woodpecker a chisel-shaped bill to bore holes in the trees. I'll give the owl eyes that see at night-time, and strong claws and a hooked beak to catch mice and other harmful beasts. Every creature will have its special part to play in the world."

Until we have studied this plan of Nature, and have seen how specially he is adapted for his life's work, we can't appreciate the beauty of the Kingfisher (Ceryle alcyon). You might not notice how closely the color of his coat matches the water until you look at him from above with the blue water behind him.

A kingfisher cannot be high above his reptile ancestors. Young kingfishers are raised in such a dark, damp place you might think, at first sight, that all of them would die of consumption. They never get even a glint of sunshine till they are old enough to climb out of the cave and take flight. Think of living in a deep well till you 
are grown! But maybe Nature set the kingfisher to live in a dark hole in order to adapt him better for his work.

A young kingfisher seems to grow like a potato in a cellar, all the growth going to the end nearer the light. He sits looking out toward the door and, of course, his face naturally all goes to nose. Everything is forfeited to furnish him with a big head, a spear-pointed bill, and a pair of strong wings to give this arrow-shaped bird a good start when he dives for fish. Of course, he seems topheavy in appearance. His tiny feet are deformed and hardly large enough to support him. I am sure a kingfisher would not pretend to walk, but he is built for a professional fisher and is a success at the business.

If a kingfisher can find a bank he always has some advantage over other birds, because he can burrow in far enough to get out of reach. For several years we have watched a pair of these birds that nested along the river bank within the city limits. One day we paddled across to the east side above the mill. The bank ran abruptly up and was well wooded. Beyond this was a short, sandy beach where we used to swim, and where a cool spring of water gushed out of the rocks just above the river. Above was a small clay bank where the kingfishers lived. I saw one enter the hole and I climbed up just below the entrance. I pounded with a stick to get him out so as to snap his picture as he left the nest. But he was like a baron in his castle. He knew I couldn't drive him out. Then I sat down for fifteen minutes until his mate returned. When she arrived with a loud clattering cry, out he came and lit on a stump while she entered. 

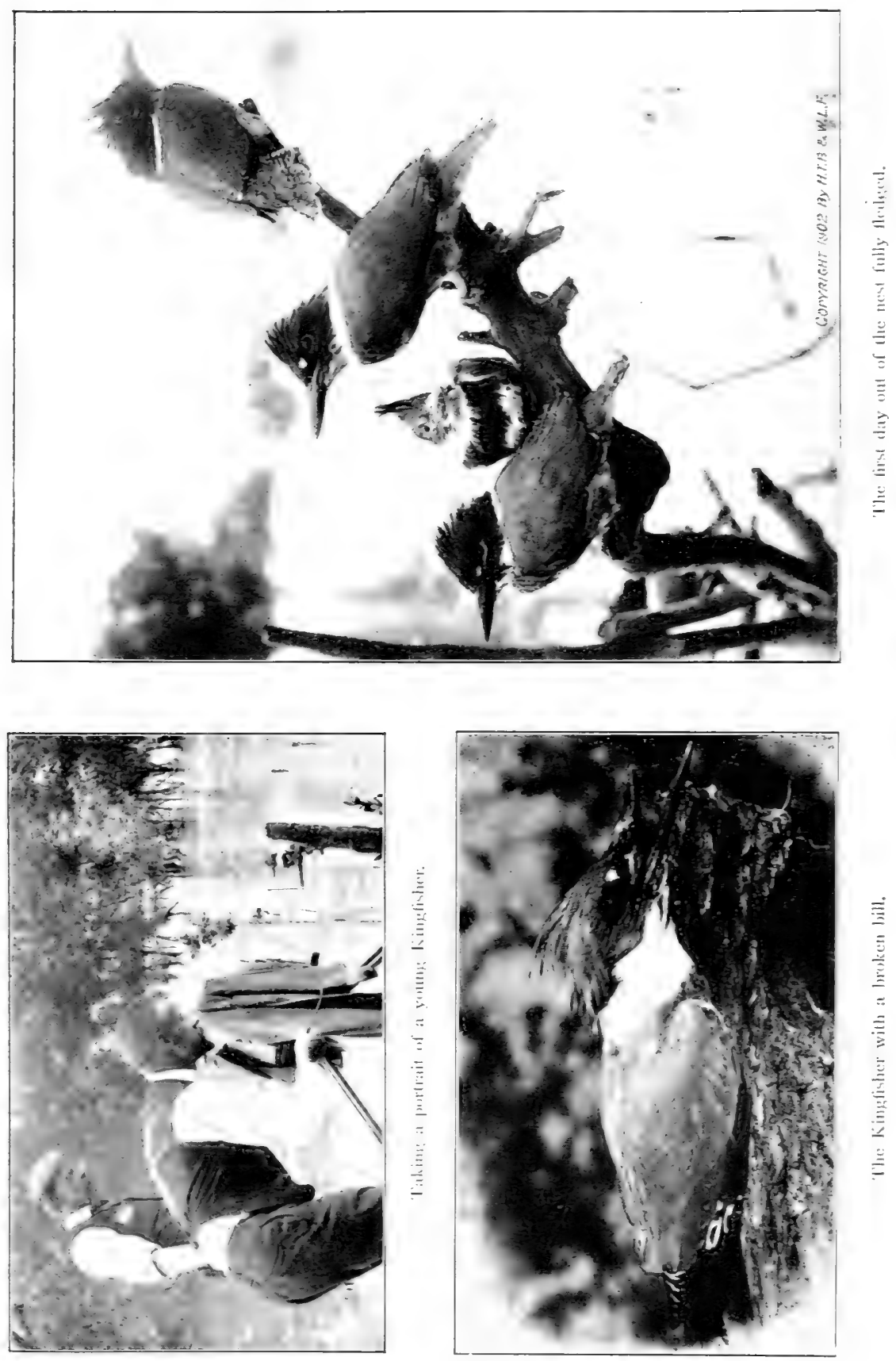


$$
\text { , }
$$


Not long after that a railroad company bought the franchise along the water front, started a big digging machine, set scrapers to work, slashed the scenery right and left and dropped it into the river. It spoiled the whole place for me, but do you think the railway syndicate drove out the kingfisher? Not much. No sooner had the big digger moved on than he plugged another hole in the new bank. The old roots and the dead tree where he used to sit were gone, but he put on civilization and set himself on a wire where thousands of volts of invisible power were passing beneath his clutched feet. He perched on the trolley pole, and rattled his call as if it were put there for his convenience. Indeed it seemed so, for it was squarely over the water's edge where he could watch the swimming minnows beneath.

I have often watched the kingfisher along the river. At times he would occupy an old willow on the bank, and he would sit there for half an hour at a time, occasionally turning his head and watching the water carefully. I seldom saw him catch anything from that place; I think he used it more as a lounging tree. He would often come flying down the river about noontime, with his head high in the air, and, like the boat coming in at the wharf, he always sounded his rattle before landing.

This old "king" had several favorite perches for a mile along the river. He was watchful and shy, and I think rather quarrelsome. Never but once did I see another kingfisher about, and that was one day when I heard a loud rattling, and looking down the river I saw two kingfishers light in the dead alder, both very much excited. They kept up a clattering fuss for a few moments, as one 
person will argue with another, then one darted at the other, and away they went dodging and turning as far as I could see. I think it was a fight as to the ownership of the property along the river, for the riparian rights seemed to belong to this one bird and all others were excluded.

It is always exciting to me to watch these birds catch fish. I enjoy it as much as pulling them out myself. I was sitting on the bank one day when my old king came rattling down the river in swift, straight flight, and swerving up, caught himself in mid-air and came to a stop about fifteen feet above the water. What an eye he must have to see a fish under the surface when going at such a pace! He fluttered for a moment as a sparrow hawk does above his prey, and dropped arrowlike, completely disappearing beneath the surface. The next instant he was in the air again with a crawfish. He wasn't wet a bit, for his clothes were water-tight; the water ran off his satiny plumage as if his coat were thoroughly oiled.

While the kingfisher catches many minnows he does not live on these alone. He often lives on different kinds of insects and shell-fish. Along some streams he lives mostly on frogs, lizards, and beetles. In the southern states, where the streams are few and run dry in summer, this bird takes to a fare of grasshoppers and mice. Think of a kingfisher catching mice! A kingfisher adapts himself to circumstances just as a flicker will dig a home in a clay bank, a telegraph pole, or a church steeple when the trees are all cut down.

Where I live, the food of the kingfisher consists largely 
of crawfish that are common along the streams. He pulls the fish apart and swallows shell and all; then the indigestible parts are vomited up later, and, strange to say, these cast-off bones, scales, and shells are used for the lining of the nest. I do not know just why a kingfisher likes to carpet his house with such a rough floor, unless he wants to adorn his home with the trophies of his many hunts. He may be too lazy to carry in anything else.

Some people advocate shooting the kingfisher at every opportunity, and, in some places, men have made laws to exterminate him, claiming that he destroys too many young trout. But the kingfisher eats very few trout comparatively. He lives largely on the kinds of fish that are of little or no value to man. What if he does catch an occasional trout to eat? Is man the proper defender of the trout? Man who never destroys! The kingfisher was here long before man came; he must have some rights, at least the right to live a secluded life along the waterways where there are no trout.

The kingfisher is not a social bird like the chippy and chickadee, and I have never found but one pair about a certain place. He is a solitary fisher and an outcast in bird society. He seems to think that a companion would talk and scare the fish, or else he is too much of a hermit to enjoy the friendship of others. But it would be a poor world if all the birds were alike. I wouldn't want a field without a meadow lark, even if it did raise a good crop of hay. It would be a desolate patch of winter woods with no chickadee. It would be a barren orchard without a robin or chippy, even if it did bear apples. I should lose much of my interest and pleasure in the river if 
the kingfisher were not there, for, to my mind, he helps to make the place what it is.

The kingfisher is a fellow of ways and means. I used to think he always took a site along the river for a home, but this is not so. Perhaps a good nesting site at the river side is not always to be had. Three years ago I found a kingfisher living in a bank on the heights back of the city. This was a good mile from his place of business, a kind of suburban home where he could enjoy the fly after fishing along the river. I often saw him go back and forth, and heard his rattle high above the housetops of the crowded city. It seemed to me the difficult problem of living so far from the river would have to be settled when the youngsters were full-grown. How could the parents get them clear across the city to the river hunting-grounds? By watching, I found that young kingfishers do not leave their nests until they are fully fledged and can fly quite a long distance. As near as I could judge the tousled-headed youngsters sailed almost the entire distance, from the high position on the heights to the river, in one try.

I was acquainted with another pair of kings that used to keep watch for fish about Ladd's pond. They had an outlook on a dead limb over the water that was usually held by one of the birds. The first year I found this pair I was especially interested. The male bird caught my attention because I could see that something was the matter with his bill. I saw him dive, and at first I thought he caught a fish, for his mouth was open, but I watched him again and each time he seemed to miss, but his mouth was always open.

This pair of kingfishers dug a nest in the bank of 



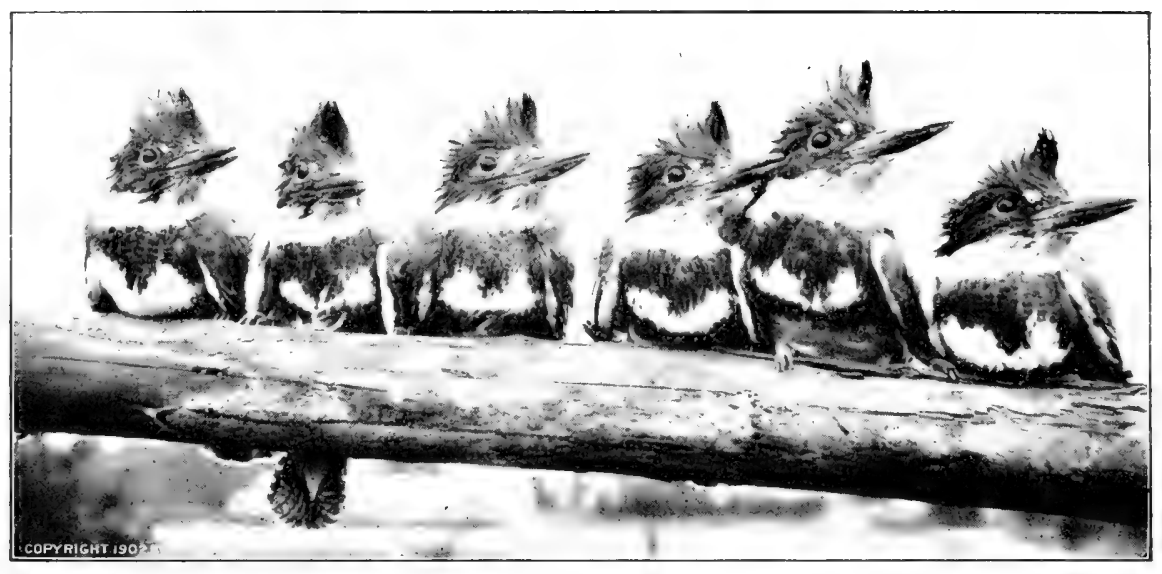

Six of the frowzy-headed Fichers in a proce.

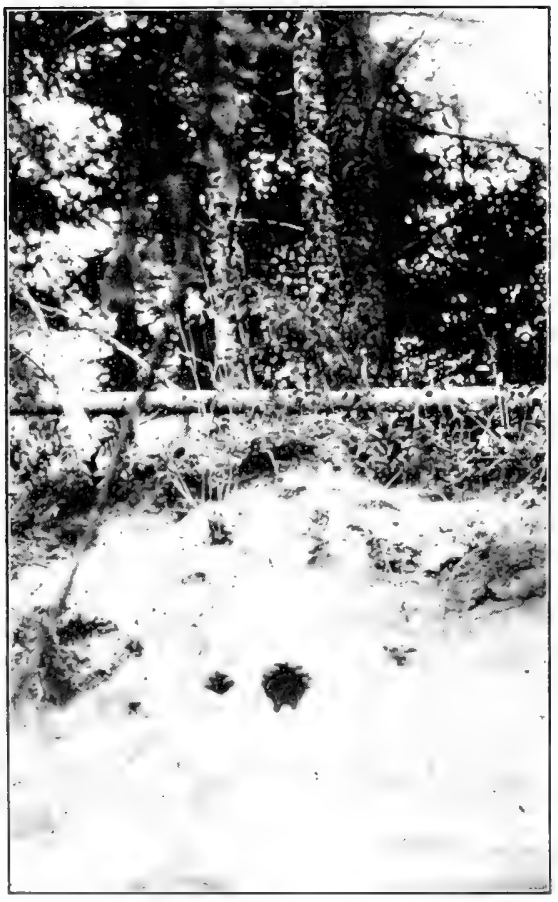

The door to the Kingtisher's home showing small hole to the lett where nest was first started; t'ie two little tracks at the bottom made by the feet of the bird.

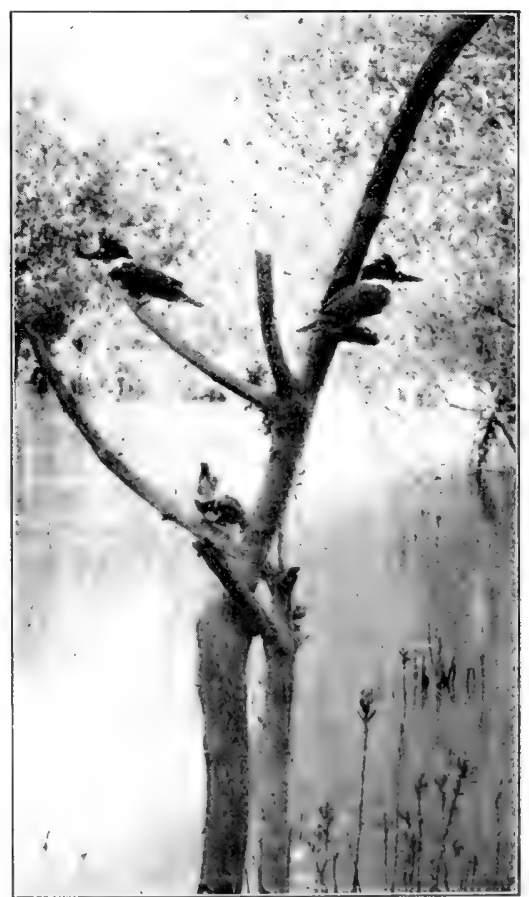

They perched on the projecting snags over the water. 
an old railroad cut about half a mile away. I found it by watching them take the overland route from the pond after fishing hours. Near the entrance I saw two other places where they had begun to dig, but it seemed they had struck hard spots and had tried again till they got a place that was soft and sandy. They chiselled the dirt out with their bills, and pushed it along with their tiny feet. As near as I could estimate, it took them a week and a half to finish the burrow. The hallway sloped slightly up and ran back four feet, where it ended in a little dome-shaped room. From the door into the nest were two little tracks, worn by the feet of the birds as they went in and out. The female generally does most of the setting, while the male returns occasionally and supplies her with food. But in this family I think the duties were somewhat reversed, for the male seemed unable to do his part of the food gathering.

I have often watched kingfishers plunge into the pools and shallows for fish, and have wondered if they sometimes did not miscalculate in their hasty, headlong dives. The more I saw of the old king about the pond the more I thought this was true. So one day we went over to the nest, which was only about two feet below the top of the bank, and measured back to where we thought the home was and dug straight down to the nest. Both birds were at home. We found the male bird had an injured bill, as we had thought. The upper mandible of the bill had apparently been broken some time before and was partially healed, but was shorter than the lower one. From the injured place the outer end of the beak bent up somewhat so the bird could not close its mouth except at the 
base. He could hardly hold a fish if he caught one, and instead of fishing for a living I think he was doing the woman's work at home and his wife was catching fish. There were six pure white eggs, and after taking a picture of the injured bird we carefully closed the nest again.

We were afraid the birds would desert the nest, but they didn't. The male continued the incubating, and it was sixteen or seventeen days from the time the eggs were laid till they were hatched. The young were blind, naked, and helpless. I knew just as well when the young kings were born as if I had crawled back through the underground passage for four feet and struck a match to look. Both birds took to fishing, and they kept the air-line trail hot between the pond and the bank.

It took almost four weeks of feeding and nourishing before the young kingfishers were able to leave the hole in the bank. We watched the nest pretty closely and were present when they came out. Not one of the youngsters was strong on the wing, and we had our cameras ready. That hole in the bank surely held one of the wildest-eyed feathery tribes I ever saw. We tried for a whole day and finally got six of the frowzy-headed fishers in a pose.

In due time all the family of young kings made their way to the pond, where they perched on the projecting snags over the water. They were not experts on the wing, nor could they spear a fish, but they were not too old to learn. It can't be an easy thing for a bird to hit a fish when it is swimming under water, not at least when the water is rough, or when the fisher does not know, by a long diving experience, how the light is reflected. 


\section{Kingfishers}

The parents fed the young for a time till they knew how to care for themselves. As soon as they developed strength and experience the old birds led them to the river about a mile distant, where they broke a way for themselves in the great world of bird life.

I never knew just what became of the father with the broken bill. He may have starved to death the following winter, or the injured part of his bill may have been gradually replaced by a new growth. The next year I saw two kingfishers about the same locality, but neither had a broken bill.

\section{THE KINGFISHER FAMILY}

The Kingfisher is a bird easily recognized because it is common everywhere along streams. It is about a foot in length, has a big crested head and a long beak. It lives on fish, plunging headlong in the water to catch its meal.

Belted Kingfisher (Ceryle alcyon): Male, crest and upper parts, bluish-gray; bill, long and sharp; under parts and collar, white, with blue-gray belt across breast. Female, like male, but breast-band and sides of belly tinged with red-brown. Common throughout the United States, arriving from the South in March. Nest in a hole in a bank. Eggs, six to eight, pure white. 
SPARROW ROW 


\section{XIV}

\section{SPARROW ROW}

7 trail that led over to Cornell Canyon started 1 right up a small ravine from the city street. The street ended at the abrupt slope that cut steeply up the gulch. Below was the paved sidewalk, above a jungle of rosebrier, blackberry, and young firs. Through and above this I climbed to the abandoned wood road that wound up the hillside. In the street below the English Sparrows (Passer domesticus) live, above, on the slope, the Song (Melospiza melodia morphna) and White-crowned Sparrows (Zonotrichia leucophrys nuttalli) nest. The Englishers dwell at the lower end of the row in what I call the tenement quarter; the songs and white-crowns live above in a more restricted district. I can be in the city with the noise and the city manners of the street sparrows, or in a few seconds I can be in the deep woods with the song sparrow.

What a contrast, the song sparrow and the Englisher! The song sparrow is a bird of character, the other is a street gamin. Our native songster is not quarrelsome. He has gentle dignity, while this imported son of England is bold and brawling. The full, rich notes that ring from the hillside are drowned in the discordant chirps about the sidewalk and street.

The song sparrow is one of the most constant singI5I 
ers throughout our land. Wherever birds live, there we may find him, whether in the mountains or along the rivers, whether along the sea-shore or on the dry, chaparralcovered deserts. He is a bird with a name that fits, and he lives in every state of the Union. But he has many different variations in name, owing to some little difference in the color of his coat, due perhaps to the place where he lives.

Early in the season I watched a pair of song sparrows at work. They dug out a hollow in the centre of a thick tussock of grass. They lined it with a bed of dry leaves and twined the grass stems around and around, the mother weaving them in and shaping the cup with her breast.

The male sparrow wore a plain brown-colored coat, and had a black spot hung right in the centre of his breast as a mark of identity. But clothes do not make the bird. He had a repertoire of song rolled up in his tiny brain that would win the affection of any audience.

The song sparrow is an artist, and he loves his art. He sings for the sake of the music. The hillside is his permanent home, for I have seen him there winter as well as summer. He stays and sings when the snows cover the hills. After a night of drenching March rain he hops out from under a brush heap and sets the woods atune for the coming of spring. Then a little later he breaks into an ecstasy, and almost loses himself in the endless changes of his song. While house building, and after the mother has cradled her four spotted eggs, the male always shows the quality of his music. After the family cares of the summer and when the sun makes him moult, he chirps more than he sings, but when the October frosts 


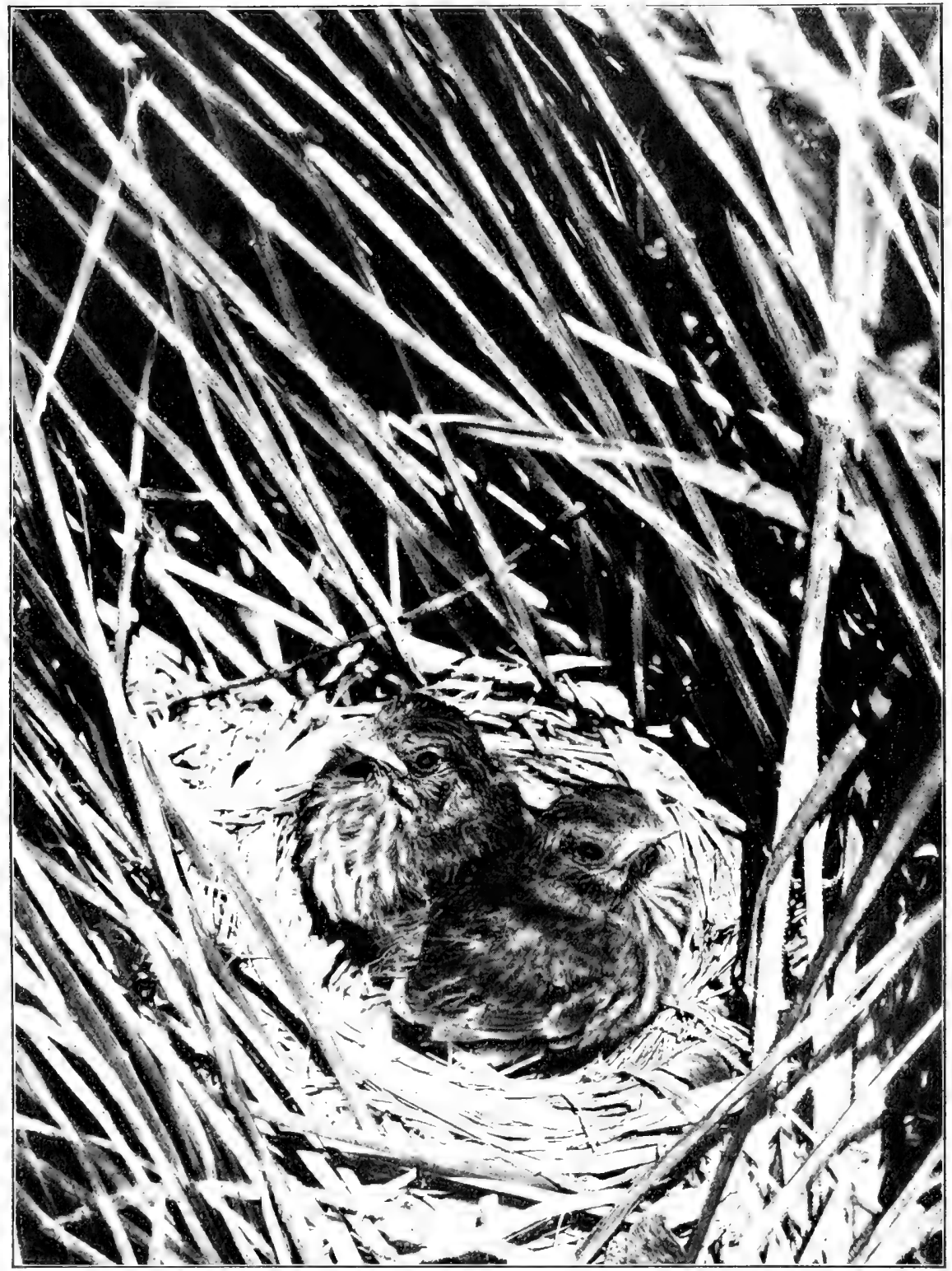


nip the leaves and the wind sends them scurrying groundward, and his coat changes, the song sparrow sits in the leafless tops and still sings of the beauties that haunt his memory.

The white-crowned sparrow has not the variation in his singing that the song sparrow has. He has one theme, and that he has sung till perfection has been reached. I never tire of the song, because it always seems to have some new association or suggestion. I remember it in my boyhood days; when the white-crowns used to come trooping in with anxious chirps to roost in the thick growth of the eucalyptus in front of the house. Before dark they would swing on the higher branches and sing of the Quaker poet, "Oh! De-e-ar! Whit-ti-er! Whit-ti-er!" And then in the darkening moments a little later would come the sad refrain, "Oh! De-e-ar! De-e-ar!" And as I lay by the open window sometimes in the dreamy hours of the night I heard the song repeated.

The white-crowns liked the hillside because they could drop down the slope to the back yard of a friend that kept a bath basin of running water and a $f$ ee lunch of crumbs and seeds. They came and ate all they wanted in the early spring, then later on, instead of eating the food, they began to carry it away. This looked suspicious, so I followed them up the hill and found four little sparrows in a grass nest on the sloping bank under a small dogwood.

In order to get some pictures of the sparrows, we had focused our camera on the ground where the crumbs were placed and snapped the birds as they came to feed. Early in the springtime the sparrows were not wild, and we got 
a number of good photographs, but later, when the young were hatched and we tried to get pictures at the nest, the birds resented such interference. We tried for several days with the camera at the nest, but the birds would not go near it when we were there. Then we focused on the top of the dogwood where the sparrows were accustomed to light, and covering the camera with limbs and leaves we got some pictures.

Once or twice I saw a dangerous-looking cat in the next yard from the sparrows' lunch-table. We have tried every lawful way of getting rid of stray cats, for they are the most persistent enemies the birds have. Some one has estimated that on an average a stray cat will kill fifty songsters a year. Of course, certain cats will kill many more than this. Most states have laws that prevent man from killing the birds. A man may be fined for killing a bird, but he may keep a cat that kills a hundred. Why can't the owners of cats see that they are well supplied with food, so that they do not have to hunt birds for a liying? Why can't people who own cats keep them at home or make some effort to teach them to let birds alone?

The next day when we scattered crumbs for the sparrows we found several feathers that looked as if they were from the tail or wing of one of our birds, and when neither of the white-crowns appeared the indications looked bad. If the old cat had killed the mother, the young might be starving.

I hurried up the hill to look after the orphans. There was not a sparrow in sight. When I climbed up to the dogwood I pushed the ferns aside, and four gaping mouths were stretched up to me. It looked as if I were 
a long lost relative arriving in the nick of time to save a hungry family from starvation. Mercy! What could I do with such a family on my hands? A big, bungling man with such tiny nestlings to feed! I sat down to think it over, but before $I$ had been there a minute here came the father white-crown, hopping from limb to limb, and chirping excitedly. To my astonishment, he was followed by the mother. Not much, the cat had not eaten her! She was well and happy, but absolutely tailless. "He didn't catch me. Here I am," she seemed to say, as she perched in the top of the dogwood over my head. She chirped, and at every chirp she jerked to throw up her tail in emphasis, but she couldn't emphasize in her old way. Whereas yesterday she was graceful and could talk with an air of dignity, now she had lost balance, and was ridiculous because she could hardly poise on a limb.

But now the tailless bird had more interest for us than she had before. We wanted to watch her and picture her, so we focused the camera on the tree-top and hid until we could get the sparrows into position.

If one thinks the tail of a bird is not an important factor in flight, he should have seen that mother sparrow try to catch a fly on the wing. Several times I saw her dart out from the tree in pursuit of an insect that flew past. Almost every time she missed at the first strike, and then I could see that she sorely felt the loss of her long, guiding feathers. She scrambled about in mid-air in her efforts to turn abruptly and start off in a new direction. She was always successful in the end, although at one time I saw her make five tries before she landed a moth. At another time she darted with such vigor that she 
almost turned a complete somersault before she regained her equilibrium.

The invasion of the Englisher in the bird world is a tremendous problem for our native songsters. It is no negro problem of the South for them, for education is out of the question, and exportation is impossible. This foreign sparrow may be all right in a narrow-streeted city where other birds do not live, but he has no place in a city with tree-lined streets and gardens and parks, for our native songsters are superior in every way to the imported street gamin.

The Englisher is the greatest bird colonizer I know. In the year of 1887 there was not a single one about the city where I live. But in the spring of I 889 I found the first pair had taken up a residence about an old ivy-covered house. They had likely come in during the winter over the usual freight-car route. It is well known that the spread of these birds is often due to the railroads, for this medium will populate any community. In cities where these pests thrive they are generally found about depots and warehouses, and in winter the sparrow asks for no better home than an empty freight-car, especially if the floor is covered with loose grain. When the doors of the freight-cars are locked, the sparrows are shut in and carried off, tramplike, to other places. By this civilized mode of travel this bird has been carried from point to point, and it is readily at home wherever it lands.

I have watched the population of our city grow, until now there is hardly a street that isn't overcrowded from the river to the hills. The sparrows have long since spread into the surrounding towns, and some day I suppose they 

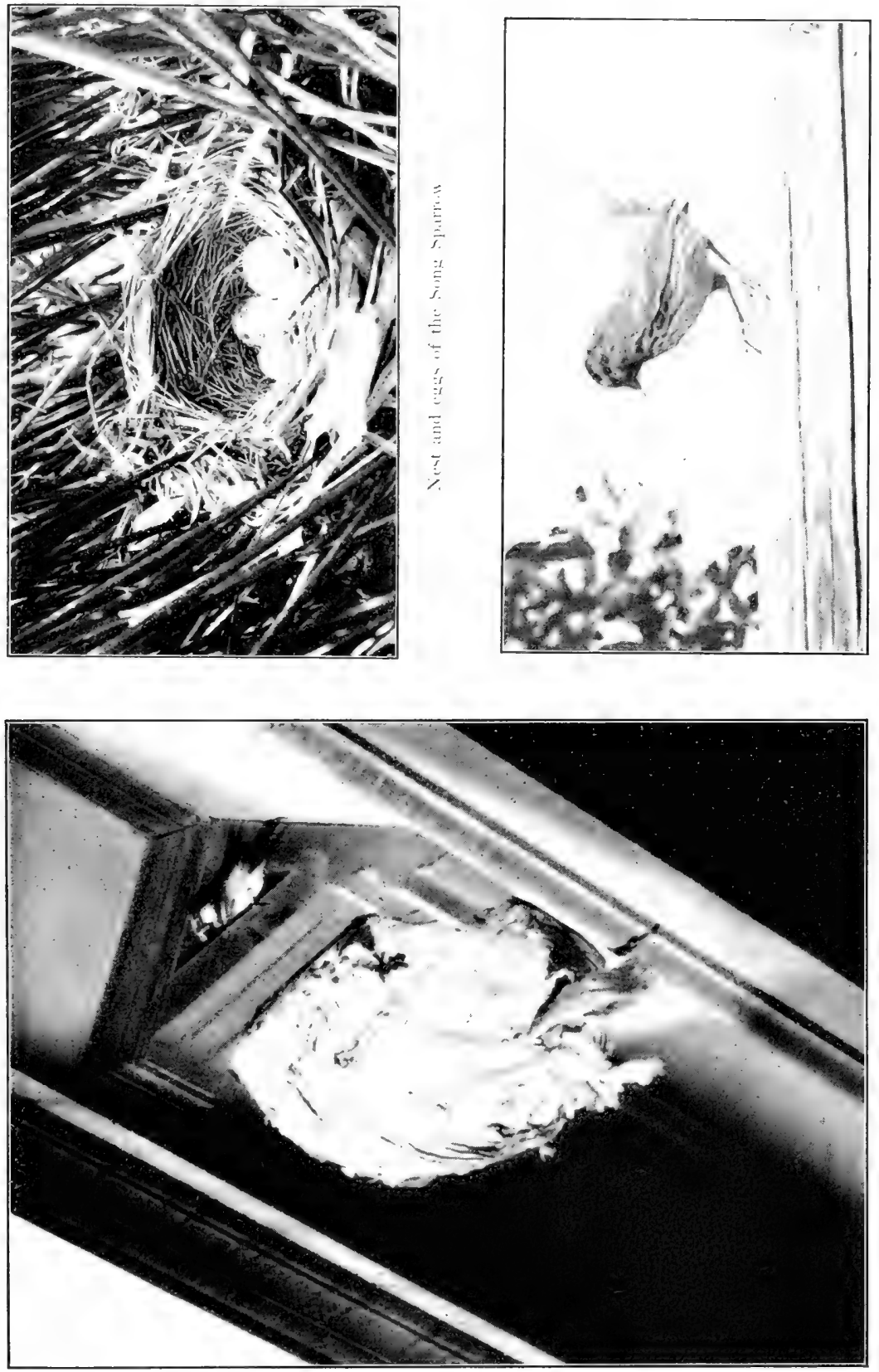

will be in dominant possession of the country as well as the city. Some people advocate a wholesale slaughter, but others always object, for they still fall back to the fact that he is a bird.

For several years I had a bird-house that was rented each summer by the bluebirds. Then one spring, when they returned from the South, they found a pair of sparrows in possession. After that I was never able to get the bluebird tenants to return, although I pitched the sparrows into the street and cleaned the house thoroughly. For every sparrow I choked and ejected another occupant came to take possession, till at last I used the box for kindling. I had the same difficulty with some swallow tenants. The bluebird, the white-breasted swallow, and Parkman wren are all common residents about our city, and each of these birds likes to take up a homestead in a good, sheltered bird-box. From my own standpoint, my property increases in value whenever one of these songsters takes up a residence with me. On the other hand, my real estate drops every time an English sparrow moves in, because no self-respecting feathered native can dwell in the same neighborhood.

No one can dispute the sparrow's success as a family man. He works overtime to people the earth. The stork of the sparrow species is a busy individual for almost half of every year. Then, in addition, the English sparrow has the advantage over the songsters that nest in the woods and fields, for they have so many natural enemies, such as hawks, owls, animals, and snakes. The Englisher lives about the crowded city, where he has little to fear, because men are unobserving and rarely interfere. 
When it comes to housekeeping, I give the Englisher credit for wanting something new and up-to-date. He loves the crosspiece in the protected top of an electric arc lamp. There he gets free light and heat. For second choice, he takes a bird-box or protected nook about a building. If necessary, he takes to a tree, but he does not like this, for nest building in a tree is more difficult. If hard pushed, he will even take a rain spout or a gutter along the eaves of the house. You can't "stump" a sparrow for a nesting site.

Down near the lower end of sparrow row some hornets built a nest up under the projecting eaves of the front porch of a cottage, just beside the bracket. I can understand how a pair of sparrows will fight for a bird-box and drive other birds away, but I never dreamed they would be envious of the hornets. But a sparrow must have a place to nest. Whether the hornets left voluntarily or with the aid of the sparrows I do not know, but the next time I passed I found the birds in possession-actually making a home in a hornet's nest. They had gone in through the bracket and pulled out a large part of the comb, and were replacing it with grass and feathers.

Think of raising a family of birds in a hornet's nest -not one, but several families! When the young sparrows grew older, I looked to see the bottom fall out and drop the nestful of little brats to the porch, but it didn't. The hornet's nest remained as strong as if it had been made for sparrows. And the sparrows liked it immensely; it was a novelty, and not another pair around had a home like theirs.

The cock-sparrow was proud of his home. He helped 
feed the children, but not because he liked it. I could see it was not in a cock-sparrow to nurse children. He liked fighting better, and between meals, even if he only had a moment to spare, he would spend it in fighting with the neighbors. He would drop down suddenly in the street in the midst of a crowd of sparrows and pitch into the nearest by jerking at a tail or wing feather. For a moment the dust and feathers would $\mathrm{fly}$, and the victor would sputter around with his wings drooping and his tail up. Then away he would go, fluttering off, foraging for fruit and bugs. He returned, dusty and dirty, every few minutes with morsels of food.

It is always a wonder to me that more of these street sparrows are not killed as they hop and flutter about the hoofs of the horses and in front of the cars. Half the time they seem to see how close they can miss getting hit, and off they flutter in sidelong flight, as if hardly able to rise. But the sparrow knows the ways of the city like a newsboy, and he is safer down amid the clatter of the wheels than his cousins are in the woods and fields.

\section{THE SPARROW AND FINCH FAMILY}

The Fringillidx, or Finch and Sparrow family is our largest family of birds. As a rule, they are plainly dressed in dull colors, and sing well. The average length is six or seven inches. This class of birds is known as seed-eaters and can be recognized by their stout conical bills, but they also live largely on cutworms, caterpillars, and other insects. The sexes are generally alike. With the English sparrow in mind as a type, other members of the family should be readily recognized.

English Sparrow (Passer domesticus), House Sparrow, Street Gamin, Tramp: Male, upper parts ashy-gray, streaked with black and brown; black patch about eyes and on throat, rest of under parts grayish; red- 
brown patch behind eye; wing with brown patch and white wing-bars. Female, grayish-brown above and gray beneath. This bird was brought to this country from England. It has spread all over the United States where it is a persistent resident of towns and cities.

Song Sparrow (Melospiza melodia): A familiar and favorite bird throughout North America. Its dress has been modified slightly by climatic influences in different parts of the country. In the Northwest, where rain is plentiful and vegetation is dense, his coat is sable-brown; on the deserts, his dress is a pale, sandy color to match the ground. But whatever the shade of his dress, he is always the same in every state in the Union. Male and female, streaked above and below; the upper parts are brown-gray and olive; gray stripe over the eye; breast is white, streaked with dark brown and a larger spot on the chest. Sometimes the song sparrow stays all winter; others return from the South in April and stay till November. Nest on the ground or in a low bush. Eggs, four, grayish-white, spotted and clouded with brown and lavender.

Chipping Sparrow (Spizella socialis), Chippy, Hair-bird: Male and female, cap red-brown; brown stripe through the eye and gray stripe above; back streaked brown and gray; breast light gray.

White-crowned Sparrow (Zonotrichia leucophrys): Male and female, white crown set between two black stripes with white stripe running back from eye; cheeks, throat and back of neck gray; back, general ashy color, streaked with brown; below, light gray.

White-throated Sparrow, similar to above, but with yellow spot in front of eye, and white throat. Both are handsome birds and good singers. 

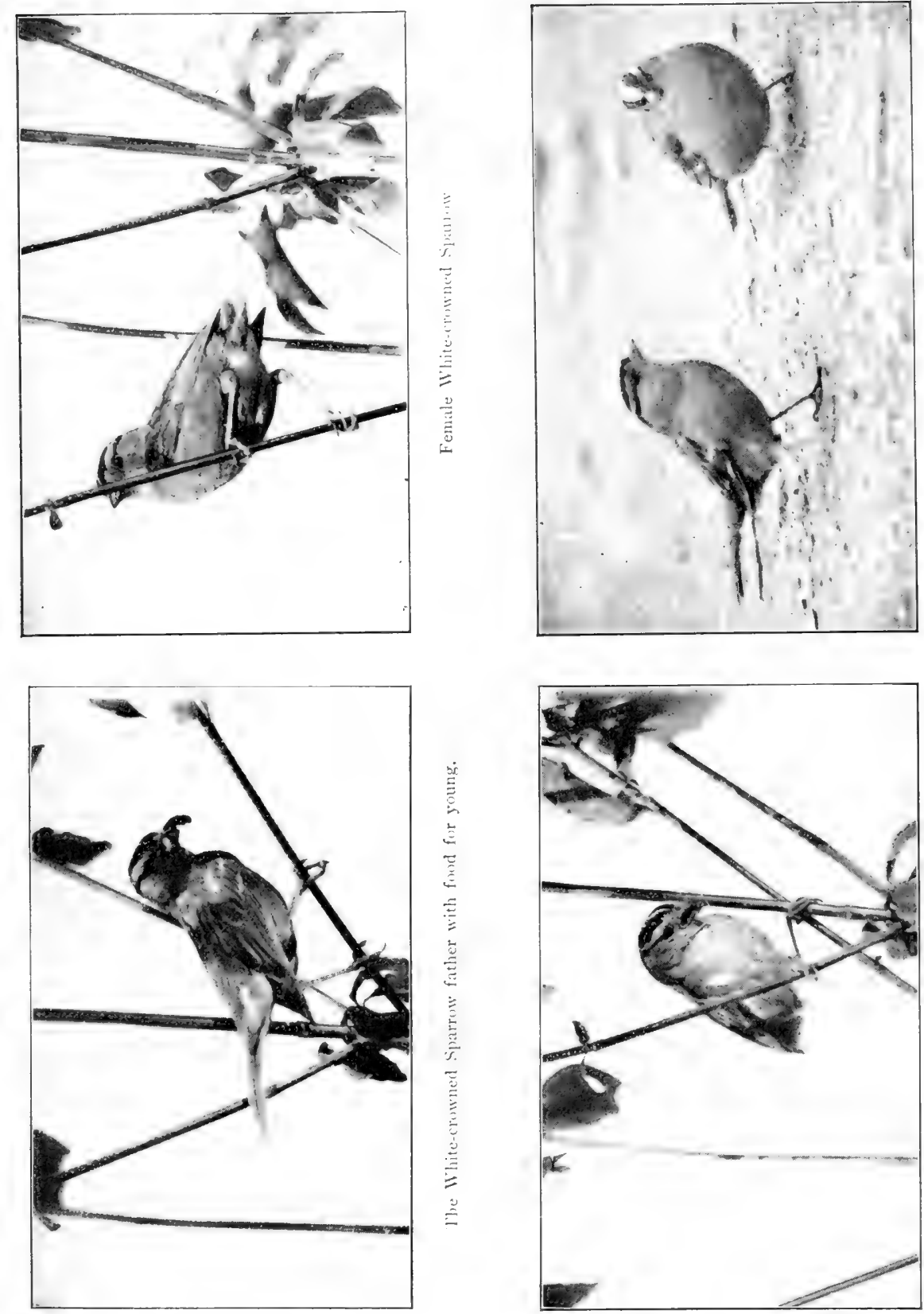

TWO STUDIES IN BLUE 



\section{$\mathrm{XV}$ \\ TWO STUDIES IN BLUE}

$\mathbf{B}^{\mathrm{LUE}}$ is not a common color among our birds. There B are many more clad in neutral tints of brown and gray than in bright blue. But a list of birds that every one should know could not be complete without our two commonest studies in blue, the Bluebird (Sialia sialis) and the Blue Jay (Cyanocitta cristata). In all our woods, from the Atlantic to the Pacific, one may find these two, one gentle and friendly, the other bold, boisterous, and untrustful.

A small flock of jays are a noisy pack in the autumn. They squawk through the woods as if they want everybody to know just where they are, but in the spring, after they have paired and are nesting, they suddenly go speechless, as if they can't trust themselves to talk out loud. And, indeed, they can't when anywhere about the nest. They talk in whispers, and flit as silently as shadows through the trees.

In the early spring I heard the jays squawking about the maples on the hill, but I knew they would not nest there; that was only a playground. A quarter of a mile below this was a thick clump of fir saplings. They would take this thicket for a home. The last week in May I searched through this and found the nest eight feet from the ground among the close limbs. 
Early in the season these same birds were blustering, bragging, and full of noise. When I found the nest one of the birds was at home. She didn't move till I shook the tree; then she slid off silently and went for her mate. In another minute they were both there, not threatening and swearing, as I had expected. It was pitiful to see how meek and confiding they had become. There was not a single harsh word. They had lost even the blue jay tongue, and talked like two chippies in love. They had a peculiar little note like the mewing of a pussy-cat. I felt ashamed to touch the home of such a gentle pair.

If this was not a twofold bird character, I never expect to see one. They go sneaking through the woods, stealing eggs and wrecking homes of others, and squealing in delight at every chance to pillage-but this is legitimate in the blue jay code of morals. I have often wondered whether jays plunder other jays, or whether there is honor among bird thieves. There are robber barons among birds as among men. But doves could not be more gentle and loving about the home, for the jays were devoted parents.

If this pair of jays carried on their nest robbing, they did it on the quiet away from home, for in the thicket, and only a few yards away, I found a robin's nest with eggs, and the nest of a thrush with young birds. Perhaps the jays wanted to stand well with their neighbors and live in peace. I am sure if the robins had thought the jays were up to mischief, they would have hustled them out of the thicket. I think we give both the crow and the jay more blame for nest robbing than they deserve, for investigation shows that they eat many insects, and in some 


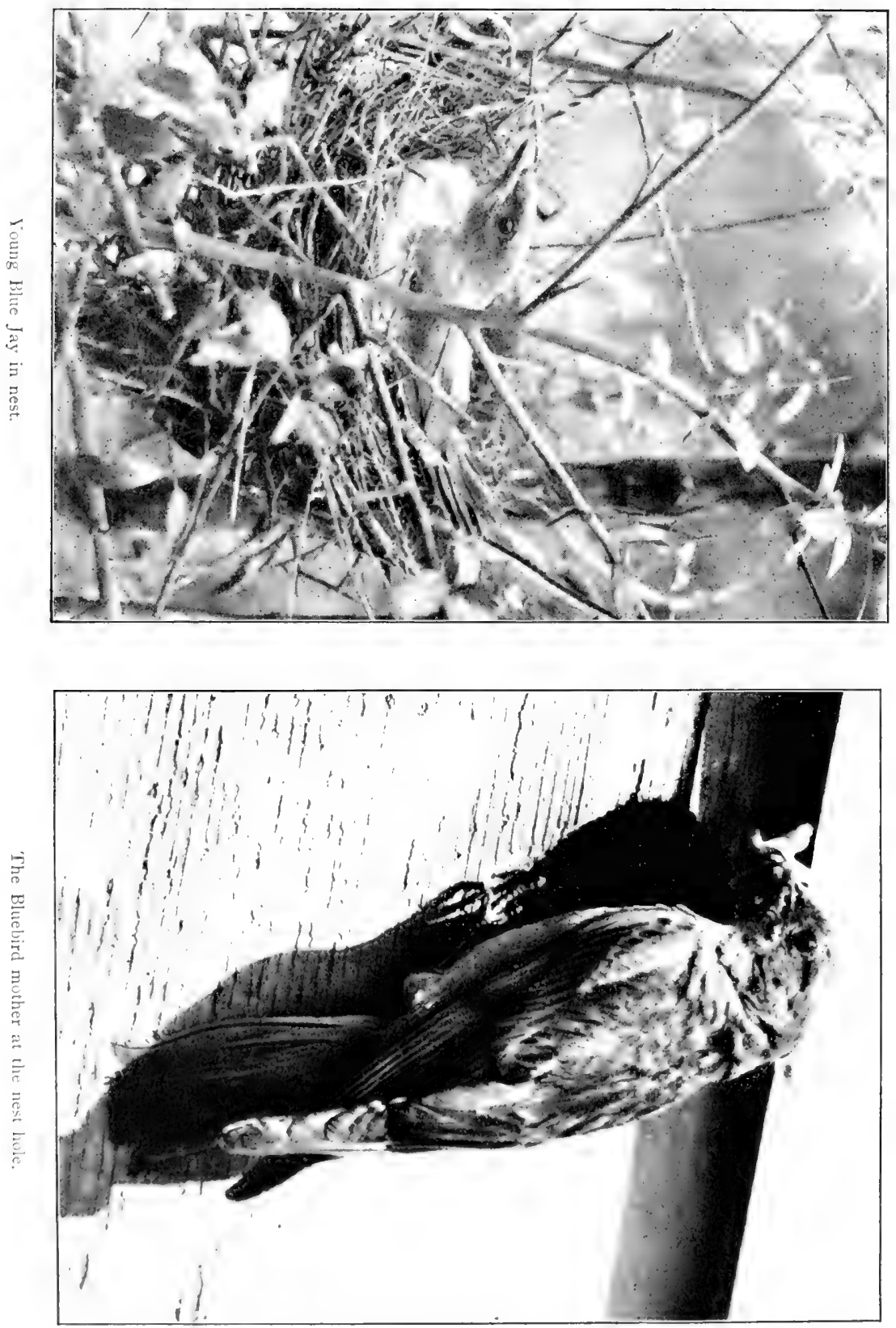


\section{Two Studies in Blue}

cases I have known the jays to live largely on wheat and other grains.

Throughout the East the bluebird is known as the forerunner of spring. The bluebirds are the first to return, and they bring the spring with them. But in the West, where the winters are not so cold, a few always stay the year around. They are together in small flocks during the day and sleep together at night. One evening I saw four huddled together in one of my bird-boxes. During the hard days of rain and snow they were continually together, and returned at night to stay in the box. I think they were partly drawn to return each day by the food I put out. When I first saw them in the back yard I tossed a worm out of the window, and it had hardly struck the ground when it was snapped up. They were all hungry, for they ate half a cupful of worms.

The bluebird, the wren, and the swallow have taken remarkably to civilization. They formerly built in holes in old trees in the midst of the woods, but now they prefer a house in the back yard. In one locality near my home we used to find the bluebirds nesting every year in some old stumps. Now several residences have been built near, and in three of the yards there are bird-boxes, and the bluebirds have abandoned the stumps and taken to modern homes. A bluebird has better protection in a back yard, and he knows it. Then if the owners like him, he grows fond enough of them to perch on the hand, and he pays rent in the quality of his song and by ridding the fruit trees of harmful worms.

Although the bluebird often lives about the city, I associate him with country life. I imagine he likes a farm 
home better than a city flat. I have a friend in the country who has bird-boxes up in various places about his farm. Most of them find occupants every year. An old square box that is set in the crotch of an apple tree is ahead in the record. This box was put up in the spring of 1897 , and was taken by a pair of bluebirds. It is only four feet from the ground and has a removable top, so that the owner may readily make friends of the tenants. When $I$ opened the box and looked in, the mother sat quietly on her eggs, and was tame enough to allow us to stroke her feathers.

This box is now covered with moss and lichens, but it is famous in bluebird history. It has been occupied every year since it was put up, and not a single year has there been less than two broods reared, and several times three. The record year was in 1904, when the bluebirds had two families of seven and one of five birds, and succeeded in raising them all. Seven is a large family for bluebirds, and it is more remarkable that there should have been seven in the second brood and then a third brood. In the eight years there have been over one hundred and ten young bluebirds hatched in this box in the apple tree. One would think the bird world would soon be overcrowded with bluebirds, but it isn't. There seem to be no more bluebirds about the farm than eight years ago, although there are generally two or three broods raised in other boxes near by. It all goes to show how the bird population decreases in numbers. The new birds of each year take the place of the numbers that die during the winter. Birds have many enemies that we know not of. Many die of disease, many starve or die of cold, and 
many are killed by birds of prey and animals that hunt small birds.

It would be interesting to know whether the same pair returns each year to the box in the tree, or how many different pairs have lived there. Sometimes the same pair has returned, but it is improbable that they have lived longer than three or four years. If one of the birds died, the other may have taken another mate and returned to the same home.

I find it an easy matter to make friends with the birds. If one has a yard with some trees and bushes, he may have a real bird retreat. Fortunate is the boy or girl who has a big yard with a tangle of bushes or an old fence-some thick trees and a wild corner where the weeds run riot. Under such conditions he ought to go right into the bird business. Arrange a shallow dish or basin, where fresh water may be kept every day for the birds to bathe and drink. This makes a most attractive bird resort for the summer. Then build some bird-houses, and put them about in the trees or on some posts, and you are sure to have tenants all summer. For the fall and winter start a bird lunch-counter by all means. Nail up a box or board just outside your window where you can watch it and where you can set the table without the least trouble. Then keep it supplied with a few cracked nuts, seeds, and crumbs. Suet chopped in fine bits may be put out, or a large piece may be nailed down, so it can be pecked, but not dislodged. The news will spread, and you will have boarders every day. If you are regular, your boarders will be regular. The guests will assemble even before the meals are served. In this way one may 
establish the closest relations with his feathered visitors. Accustom them to your presence gradually, and do not make sudden movements, and the birds will learn not to be afraid. Later you may even have the birds come at call or take a bit from your hand. Such a bird friendship is worth working for, and such familiarity with the wild birds cannot help but make a boy or girl's life better.

In the side of our tank house we bored two holes about four feet apart and nailed up boxes on the inside. One of these was soon taken by a bluebird. The female went in and looked the box through, and in a moment came out and perched on the wire while the male took a look. The next day the female began carrying straws. She had a devoted husband, but he was merely an attendant when it came to work. He watched and applauded, but he didn't help build. I don't know but that he was too lazy; or maybe he didn't know how, or the wife didn't want him bothering while she was building to suit herself. It looked to me as if he were ornamental without being useful. But after watching awhile, it seemed that it was her duty to build and his to watch and encourage. When she carried in the material and fixed it, she popped out of the hole and waited while he went in to look, and then out he would come with words of praise, and away they would fly together.

I had a splendid arrangement to watch the builders at close quarters. I could go in the tank house and close the door, and then in the darkness I could look through a crack in the box, and with my eye less than a foot away could watch every movement the birds made. While the 


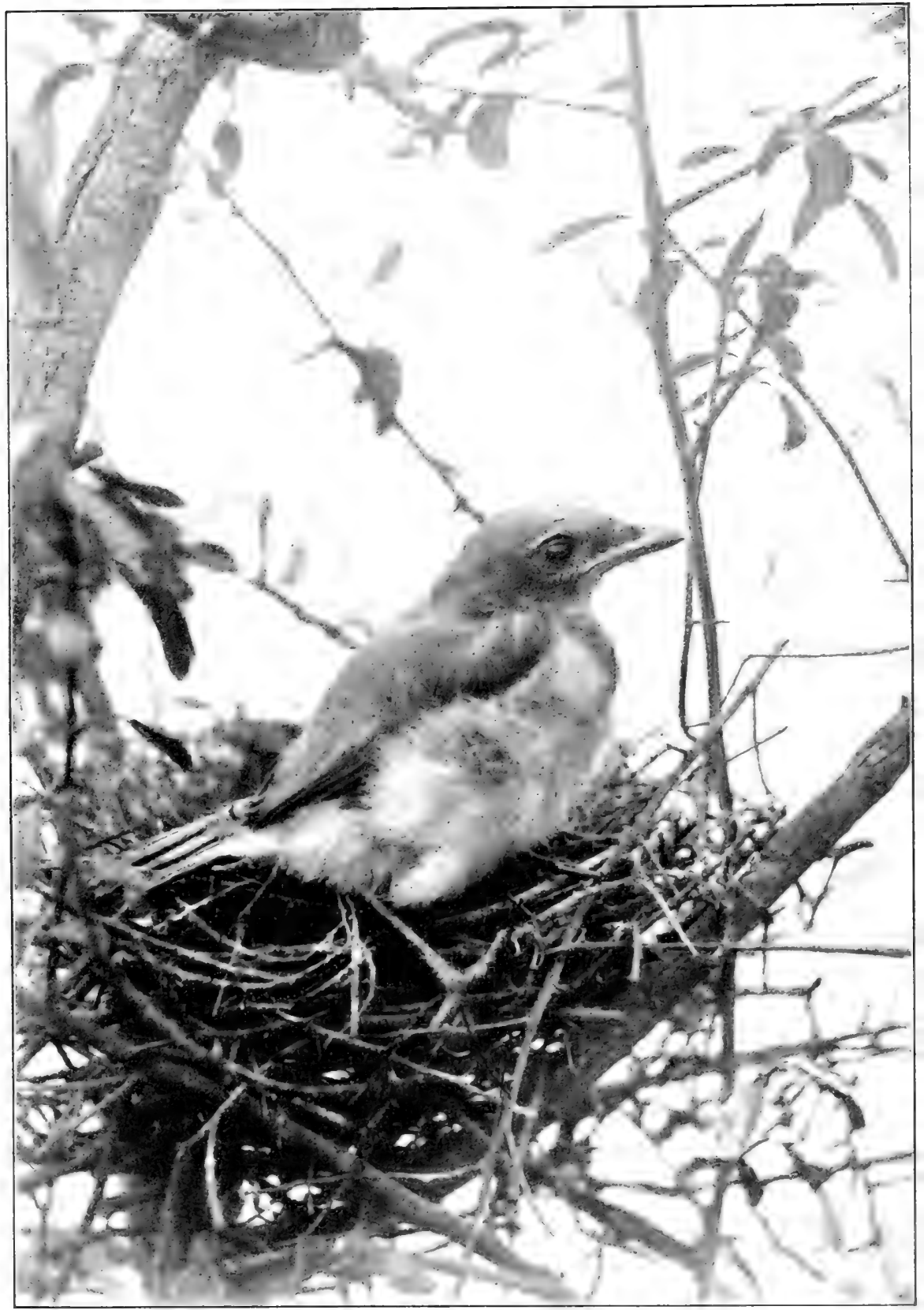

Simus line Jay just leaving ne-t 

mother was setting on the eggs she became very tame, and we often reached in and stroked her feathers.

When the young birds came I watched the mother come to feed and brood her young. The father was the ever-watchful admirer, but the mother was all business, and paid no attention to him except to knock him out of the way when he was too devoted. The mother always brought in the food, and the father kept staying away more and more, until the young birds were grown.

One day while I was watching, the mother was feeding the youngsters on maggots almost entirely. She was gone quite a while, but each time returned with a large mouthful, which she fed to the young. Occasionally one of the young failed to get all of them, and if one dropped the mother picked it up and ate it herself.

One of the eggs was addled and did not hatch, but the mother was very fond of it. She would look at it almost every time she returned, and would turn it over, and then cover it a few moments, as if she were sure it contained a baby bird.

The nest was lined with horsehair, and once when the mother fed one of the chicks, the food caught and the little bird swallowed the hair too, but both ends stuck out of his mouth. He kept shaking his head, but could not get rid of it. I waited to see if the mother would assist him, but she didn't seem to notice his trouble, so I had to reach in and dislodge the hair. Otherwise I am afraid it would have fared badly with the chick.

These bluebirds had five young in their first brood. When the first youngster left the nest the father became more attentive, and helped care for the little ones that 
were just starting out into the world. They all stayed about the yard till the young knew how to hunt for themselves. Finally three of them disappeared. I suppose they went off with other bluebirds, but two of the young still stayed with us. The parents themselves seemed to disappear for a few days, and I thought they had left for good. Then one morning I saw the mother enter the house again, and the father was there, too, perched on the wire. He was more attentive than formerly. The next day I found a fresh egg in the nest. The parents had returned to raise a new family.

There were only three eggs in the second setting, and all hatched. The two young birds of the first brood followed the father about while the mother was setting. Then when the mother began feeding her second family I made some interesting observations. Her older children began following her about to hunt food, and to my surprise I saw one of them bring some worms, and after the mother fed, the young bluebird went into the box and fed her small brothers and sisters. After that I watched closely, and often saw the birds of the first brood feed the little ones of the second brood. Perhaps the two birds of the first brood were girls and took readily to housework. They may have been learning for the next season, when they themselves expected to have a home.

One of the young birds was very enthusiastic in helping her mother. For a while she fed as often as the mother. Several times when the latter brought food, the young bird flew at her and tried to take the morsel she had in her mouth, as if saying, "Let me feed the children," and twice I saw the mother yield and let her older 


\section{Two Studies in Blue}

child feed the younger ones. It was a very pretty bit of bird life to watch these bluebirds. We were anxious to get a photograph of the mother and the young bird helping her. We tried by getting on top of the house and focusing the camera on a wire where the birds often alighted. We finally got one view of the two as the young bird was just in the act of jumping for the worm the mother held.

\section{THE BLUE JAY FAMILY}

The Jays are one branch of the Corvidæ or Crow family, but in contrast to the crows, the jays are birds of bright and varied colors, generally blue, and often the head is crested. The jay is a well-known character everywhere, but has a bad reputation. He is about twelve inches long and lives on grain, grasshoppers, caterpillars, and often eats the eggs of other birds.

Blue Jay (Cyanocitta cristata): Male and female, crest and back, light purplish blue; wings and tail, blue barred with black; throat, gray, fading to white on belly; a black collar across lower throat and up sides of head behind crest. Lives throughout eastern United States, where it nests in May and June, making a bulky nest generally hidden in a thick tree. Eggs, four to six, varying from greenish to buff, thickly marked with brown and purplish spots.

California Jay (Apbelocoma californica): Male and female, upper parts, blue; sides of head, grayish-black, with light stripe over eye; under parts, white, washed with light blue on sides of chest. Nesting habits same as above. Lives on Pacific Coast from Columbia River south.

\section{THE BLUEBIRD FAMILY}

This family of songsters may be recognized by the rich blue dress. The Bluebird is about seven inches in length. It frequents the woods and waysides and likes to nest in bird-boxes about the dooryard. It is a quiet, gentle-mannered bird and readily becomes semi-domesticated. 
It lives largely on caterpillars, grasshoppers, and wild berries. It is called the forerunner of spring because it often comes before the first spring days begin.

Bluebird (Siala sialis): Male, azure blue above; wings, blue with dark edgings; breast, brick-red and lower parts, white. Female, duller blue; breast, paler and more brownish. Young birds have speckled breast. Lives throughout eastern United States, one of the first birds to arrive from the South, coming generally in March. Nests in an abandoned woodpecker hole or in a bird-house. From four to six pale blue eggs.

Western Bluebird (Siala mexicana occidentalis): Resembles the above closely, with more reddish-brown on the back. Inhabits the Pacific Coast region. 


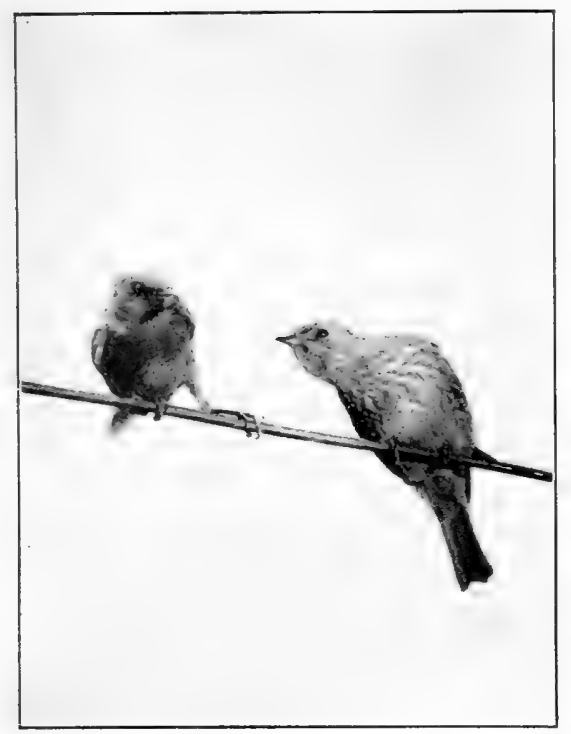

The young Bluebird was just in the act of jumping for the worm the mother held.

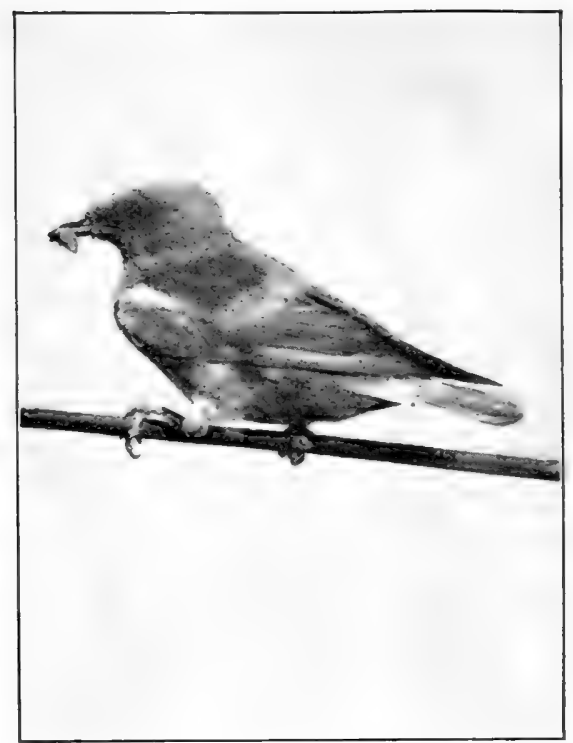

The male Bluelird with food for young.

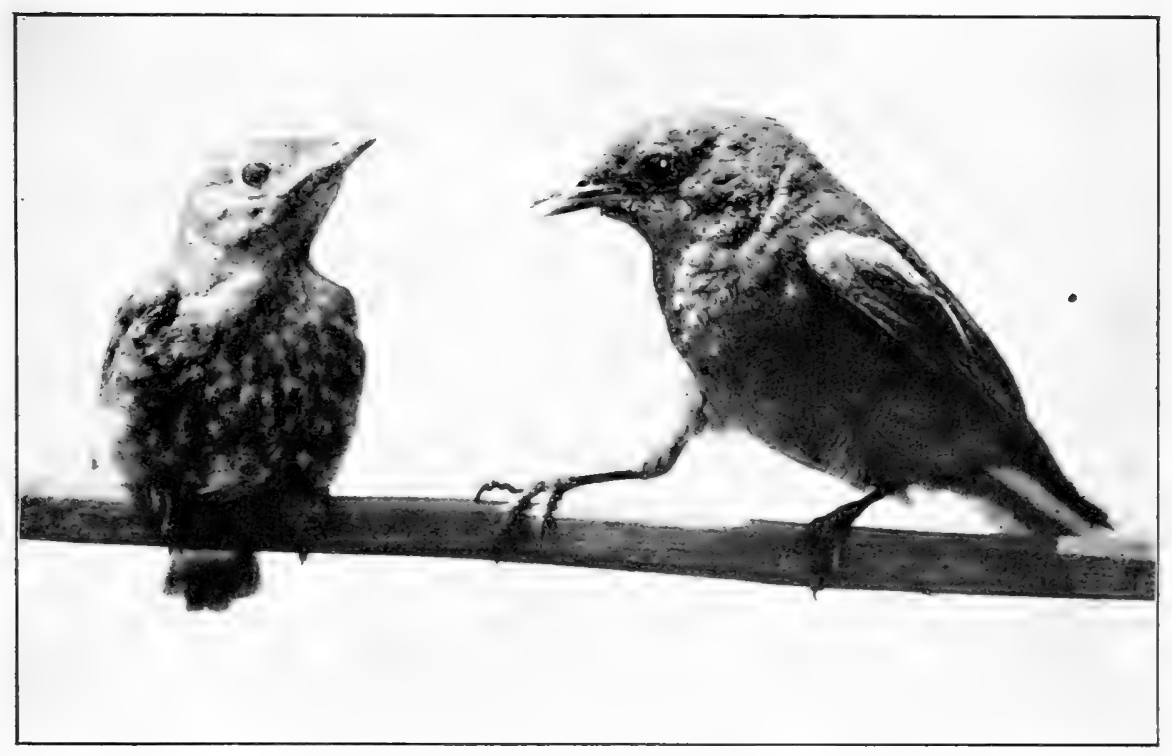

A mother Pluebird poising an instant after feeding her young. 

BASKET MAKERS, THE VIREO AND ORIOLE 



\section{XVI}

\section{BASKET MAKERS, THE VIREO AND ORIOLE}

OES the bird build its nest by instinct or does it exert a reasoning power? Why doesn't the vireo build a nest like the robin? The vireos build basket nests; why is it that all vireo nests are similar? A young vireo that has never built a nest will make one as his parents before him. He undoubtedly has the instinct to make a basket nest, and does not know how to make any other. But we often see nests that are poorly built, and this shows that young birds are not as skillful as older ones.

Are birds influenced by the sense of the beautiful in making their nests? Do the vireos adorn their nests with lichens to make them attractive, or to make them invisible among the leaves and limbs, or just because they find the lichens handy to build with? Many people have argued that the birds are influenced principally by one of these factors, but I see no reason why all these different things do not influence the bird as it would influence us if we were to build under similar circumstances.

Imitation is perhaps the strongest factor in the life of the chick from the time it leaves the shell till it is a full-grown bird. Nest building, like singing, may be largely by imitation, and the lasting impressions in a bird's life must be during the first few weeks of its existence. 
Experiment shows that a baby linnet brought up by a titlark took all the notes from that bird, and even though placed in the company of other linnets later, he did not sing as they sang. This law among birds that makes the earliest impressions the habits of after life would make a strange bird world if revoked. If the nestlings did not learn the songs from their parents, what a grand medley we should have; robins singing like wrens and larks like sparrows, till we could no longer tell birds by their songs.

It is largely this habit of imitation in the bird that prompts him to adorn his nest with lichens and to build a home that blends so closely with the surrounding branches. Some people would have us believe that the bird has reasoned it out, and builds in this way to protect his nest from enemies. The rufous hummingbird is accustomed to see the lichen-covered limbs of the trees, and when it builds it collects these lichens and shingles its home with them. Out of fifty nests of the rufous hummer all were built after the same manner. But the black-chinned hummer of southern California generally builds in the sycamores and oaks. The leaves of the sycamores are light-colored, and have a fine yellow down on one side. The bird selects this down and builds its home entirely of it, so it is light yellow and can hardly be seen among the leaves surrounding it. The two nests are very different in appearance, but the fact that both nests are protectively colored is from the use of handy material rather than the result of the birds seeking certain things for the purpose of protection.

The last week in April, before the trees were well leaved, I heard the call of the Warbling Vireo (Vireo gilvus). 



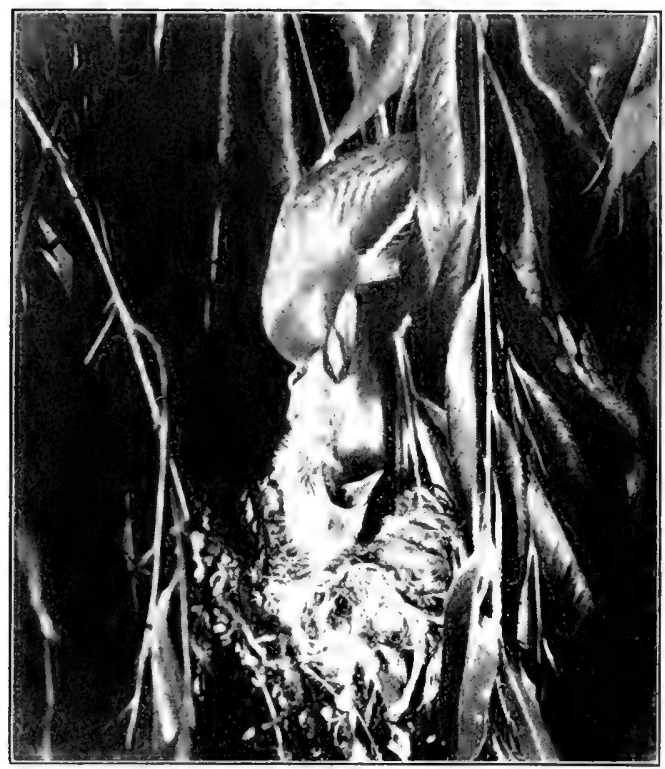

Mother Oriole feeding young.
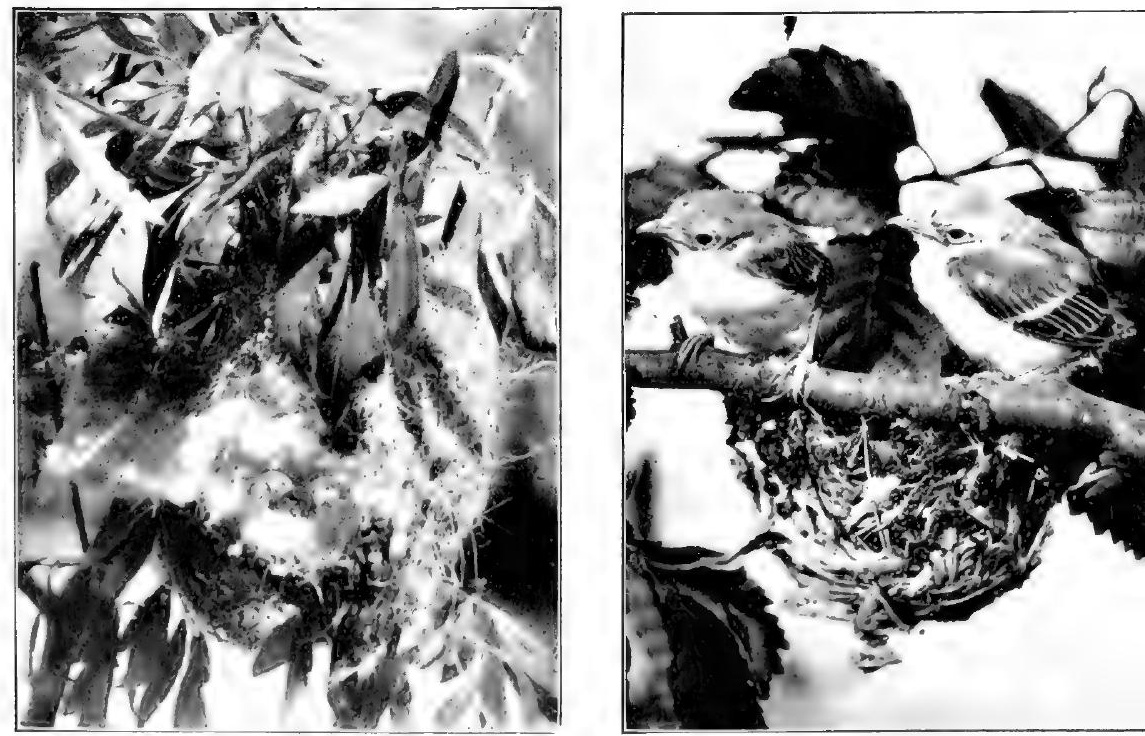


\section{Basket Makers, the Vireo and Oriole $\quad$ I 77}

"See here! See me!" and a moment later, "Sce here! See here! See me!" he said from the hillside, and I went up to look at him. He sang for me within a few feet. He had just arrived from the South and he was hungry -no time to bother with people. He jumped from limb to limb looking, always looking for food. The singing was spontaneous, thrown in for every worm he found. There was no mate about; she had likely not arrived yet. He intended to keep on singing till she did come. I had been watching and waiting for the vireo because I wanted to study his method of nest building and get his picture, so I watched him closely during the weeks that followed.

It is very likely that both this vireo and his mate had built nests before, for they built such a pretty one. It was not a haphazard site they selected. They searched for positions and studied different places. Then at last they decided upon a hazel bush. Both began work, and they worked independently, each hunting moss and fibres and weaving them in to his own satisfaction. Although they worked according to their own ideas each was satisfied with what the other did. When it came to decorating, I think it was the wife who shingled the outside of the home. She, perhaps, had more taste than her husband.

The vireos built their nest in a good position for it was entirely shielded by leaves. You couldn't see the nest from the front; it was roofed over with a big hazel leaf, and in hot or rainy weather the mother had this canopy over her head. It was even more useful when the young were hatched, for both mother and father were away at 
times hunting food, and then the nestlings were protected by the leaves. Each time the mother had to reach under and raise the roof to feed her bantlings.

In order to get some pictures we tied a string to the branch that held the basket nest and anchored it two feet nearer the ground. When the mother returned with a worm, and dropped from the upper branch, where she always lighted, to the limb where the nest was hung, she fluttered in the air trying to light on her accustomed perch. She looked puzzled and went back to try it again, but when she put her feet down to light there was no perch. Then the father came and he did the same thing. There was no alarm. They looked at each other a few minutes and talked, and then the mother dropped to the nest and fed her children. She saw me lying in the grass and scolded mildly for my impudence. But she straightway forgot the nest had been lowered, for when she came back she missed the limb again and tried to light where the nest had formerly been. Then, to be sure she was not dreaming, she lit near the foot of the branch and hopped along till she came to the nest.

Once the mother came with a triangular piece of food in her bill, that looked as if it might be from the back of a beetle. She thrust it into one open mouth, but the chick could not swallow it. She watched him a moment and then took it and thrust it into another mouth. This chick had the same trouble, but she flew away leaving it there. And all the time the young bird sat there with the food bulging out of his mouth. Several times he tried to swallow it, but it was no use; it was too big and unyielding. When the mother came again and saw the food 
Basket Makers, the Vireo and Oriole I79

still in his mouth she tried another chick with it, but he could not get it down. She had to try several times before she seemed to realize that the bite was too big, and then she dropped it over the nest edge.

Just across the ravine from our vireo's nest a pair of Cassin vireos had a home, and all but one of the young birds had left the nest. This last chick kept calling for food, so we put him on the hazel limb beside our nest. Then we waited developments, half expecting the mother to knock him headlong when she returned. The minute the new bantling heard her coming, open popped his mouth, and as he stood between her and the nest the mother couldn't resist but gave him the mouthful. But the next time she came she stepped right over him as if he were nothing more than a leaf, and she did the same every time after, paying no attention whatever to him, so we had to return him to his own home where he was cared for by his own parents.

While the vireos were in the midst of household affairs we found an Oriole (Icterus bullocki) building its basket nest in a weeping willow that stood in the chicken yard. Last year the nest was swung in the very top branches, but this year they built among the leaves beside the chicken house, twelve feet up. We tied a rope up near the base of the limb and drew it tight from the fence, so when the mother returned with food for her young she found her house had sunk four feet nearer the ground. Then we set up a step-ladder so we could look into the basket.

I never saw birds more in love than the orioles were. We watched them from the time they were first mated. 
They were always together in the trees about the orchard. Beyond the chicken yard was an old deserted cabin. A part of the window had been broken out, and the pair often sat there on the sash. Sometimes they hopped in and sat on the table inside. I didn't know at the time, but I think they were attracted by the reflections in the glass. The female would flutter before the glass and then light in the broken pane and look about with the most mysterious expression.

Just at the side of the house were three large cherry trees with wide-spreading branches reaching almost to the windows. When the dark shades were drawn the windows made a very good mirror. One day when the pair of orioles were playing about the cherry trees I saw the female light on a low branch in front of the window. Then in a few moments she flew down and lit on the sash. The next day I saw both the orioles at the window. The male sat near on the branches and the female on the sill. As I watched she fluttered up against the window, trying her best to hang on, till she slipped down to the bottom. Then she turned her head and watched in the glass. The more she looked the more excited she seemed to get, and she fluttered against the glass till out of breath. Then the mate flew down beside her. Time after time the birds were seen at the window. Had the lady, like Narcissus, fallen in love with herself, or was curiosity leading her on? I never saw a pair of birds with such a mania for windows. I thought the male would hurl himself at the reflection he saw in the window, but, contrary to my expectations, he took the picture as a matter of course. He sat on the sill or perched near by on the branches while his 

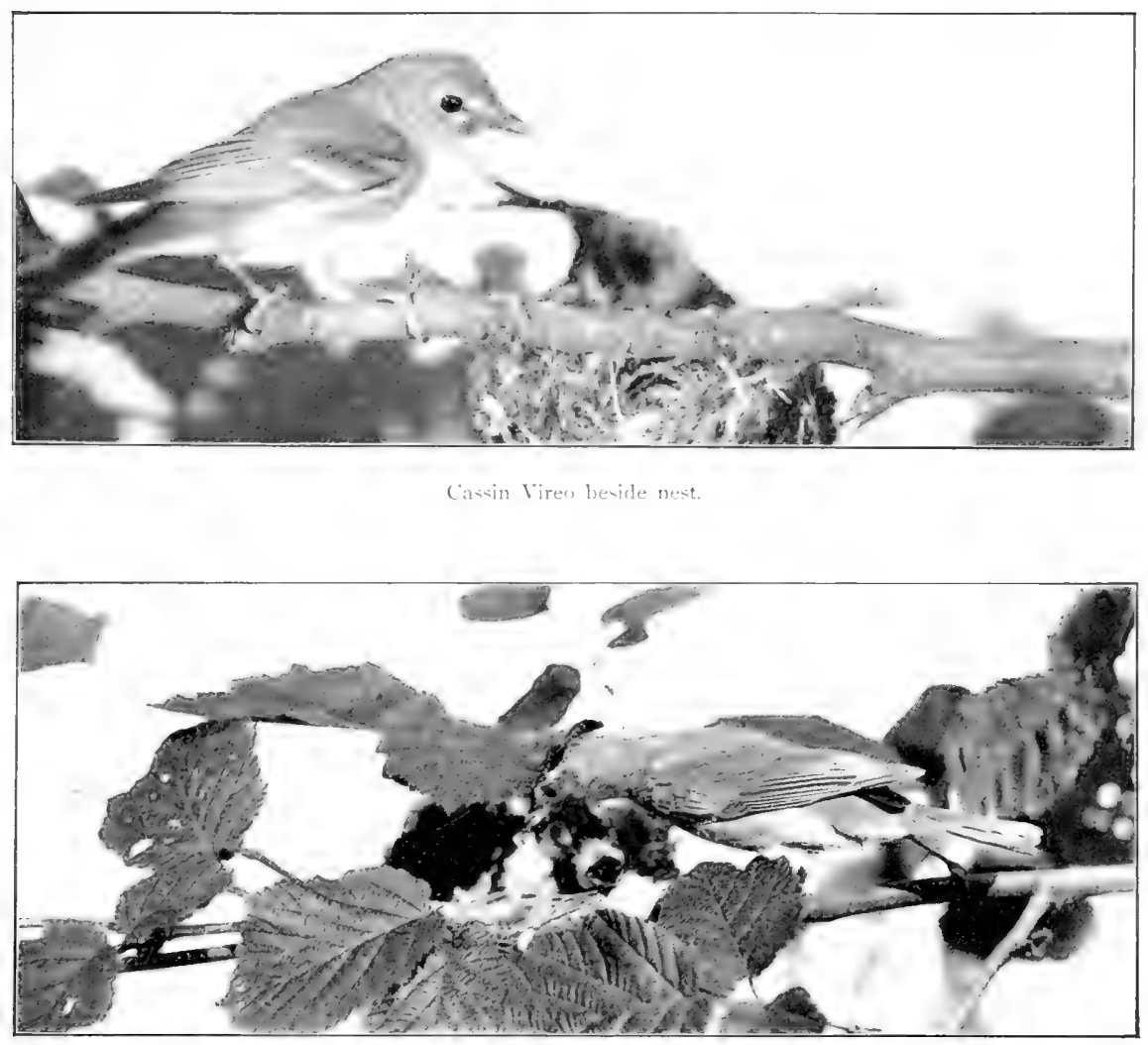

Warbling Vires feeding y+unc.

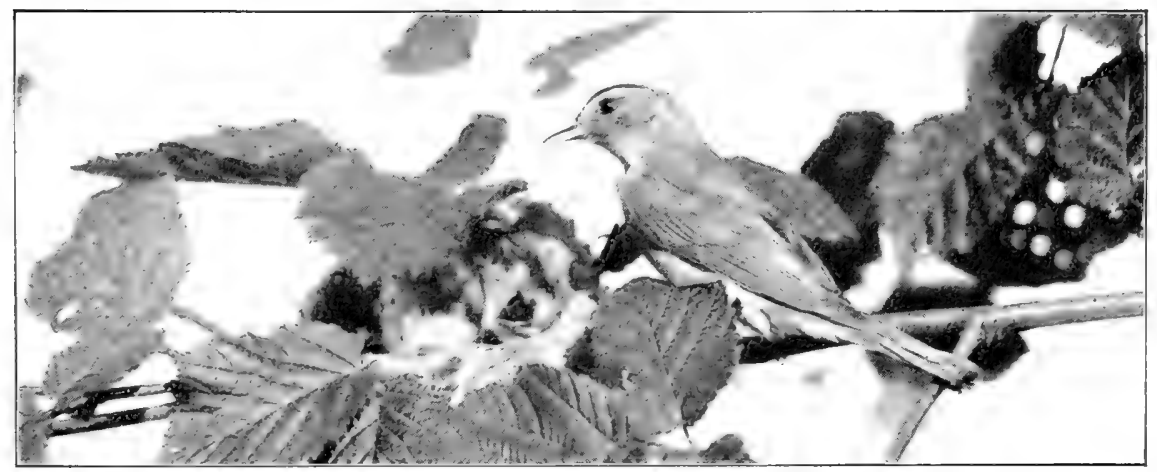

Warbling Vireo at nest after feeding. 


$$
\text { . }
$$




\section{Basket Makers, the Vireo and Oriole I 8 I}

wife, so intent with the bird in the glass, flew against the window, but never accomplished anything except to slide to the bottom.

I fear she would have gone insane flying against the window had the nest building and family cares not taken her away. But I don't believe there was a day, unless it was after the mother began setting, that the pair did not appear at the window. The bird in the glass house had a great fascination, and the window itself was streaked and spotted by the feet and bills of the orioles.

One day I saw a streak of orange and black flash into the cherry tree beside the willow. It was a male oriole, but not the guardian of the nest, for he was a more deeply marked bird, an older oriole, for the plumage of the males grows deeper in color and more striking as they advance in years. But the new arrival had hardly lit when there was a flash of color, and the father of the nestlings darted at the intruder like a little fury. Through the branches, under trees, over the barn, and across the orchard the righteous pursuer and the invidious pursued darted. A father bird has the right to the trees about his home. This tradition is sacred in bird life, and no matter how large and strong the meddler he cannot long stand the attack of an enraged father.

We set one camera on the top of the ladder pointing at the nest, and draped it with willow branches. The mother would peek in from the back door, and then edge slowly down the long braids of the willow limbs to thrust a morsel in the mouth of a clamoring baby. The father fed occasionally. He often paused on a dead limb over the chicken house. We placed another camera here on the 
top of the old house and hid it under a green cloth and branches, and in this way got some snaps of him. While we were waiting during the afternoon for chance shots at the birds, I heard the challenging call of the male oriole down at the other end of the orchard.

During the next day we watched about the oriole's nest; both the birds were feeding the young, and the male was not any wilder than the female. As the day wore on the male seemed to be doing most of the feeding, for the visits of the mother were less frequent. The nest was made almost entirely of horsehair and the orioles knew just how to use the material, for it was woven so that the sides bulged out with the constituency of a hollow rubber ball. But horsehair is often dangerous to birds. I saw the father almost get caught in one of the hairs. When he went to feed the young he put his head through a loop in one of the hairs, and when he started to leave he twisted the noose about his neck. He jerked back several times to no avail, and then fortunately turned back the same way, and the noose slipped over his head, ruffing his feathers, and he was free. Had he not made the right turn he would surely have hung himself. I know of several cases where birds have been hung in this way. Horsehairs and strings are comparatively new things in bird architecture and often cause trouble, just as in rapid flight a bird in the city often strikes a telephone wire and is killed by the force of the blow.

The following day I again saw the flash of the intruding black and orange and the accustomed hot chase through the orchard. In the afternoon I noticed that the young orioles were fed entirely from the bill of the father. 


\section{Basket Makers, the Vireo and Oriole 183}

The mother came only once, but she did not bring food. She sat about in the cherry tree for a while and flew to the branch over the nest, but did not go near her children. It seemed to me this was rather negligent of the lady of the house, but the father was doing well. He returned every few minutes with food, so the children had their meals.

Next morning the mother did not appear once about the home, and I became suspicious. We watched during the whole afternoon, just because our curiosity was aroused, but she did not return. The father was alone. That night a heavy rain blew up. The three young birds were partly feathered, and we feared the father would not hover them. When we went out with a lantern our expectations were realized, and we tried to tie a roof over the nest. In the morning the young birds were dead, for the water had run down the branches and chilled them to death. The father was there with food, but to no avail. And the mother, where she was I do not know.

During the nesting period a heavy rain creates havoc among bird homes. I've seen half a dozen different families of young birds killed by a heavy shower. And how many more there must be that we do not see. If the nest contains eggs or very young birds, the mother will hover them and protect her babies from the water. But when the birds are half feathered out she in many cases no longer hovers them, for they are able to keep themselves warm.

I have never known just what to think of this pair of orioles, but I know from experience that birds are often fickle. I know of an instance where a newly mated pair 


\section{84 American Birds}

of orioles were living about a grove of trees, and the male bird was in such fine plumage that a collector shot him for his cabinet. The next day the female appeared with a new husband, who was as bright and fine looking as the bird she lost the day before. At the first chance this male was also shot, partly, it was said, because he was such a fine bird and partly to see if the female would find another as readily. Two days later she appeared with a third husband, who went the way of the two former ones. The female then disappeared for a few days, but returned again with a fourth suitor. These two began building in a eucalyptus tree and soon had a family of young birds. This may be a remarkable case of wooing and winning, for I can't see where this supply of male birds came from unless the widow oriole was breaking up other families.

\section{THE VIREO FAMILY}

These birds are often called Greenlets; the name comes from the Latin vireo, meaning $I$ am green. They are small birds about five or six inches in length, and dressed in soft tones of olive-green without any brilliant markings. The bill is slender but stouter than a warbler's, and has a slight hook at the end. They have sweet, warbling songs, and are very active in their search for insects among the trees.

Warbling Vireo (Vireo gilvus): Male and female, above, pale olivegreen; grayish on head and more olive on rump; white streak through the eye; no wing bars; below, dull yellowish, whiter on throat and belly. Lives throughout North America in general, arriving from the South in May and remaining till September or early October. Nest, cup-shaped, hanging in the fork of a branch. Eggs, three to five, white with brown dots more numerous on larger end.

There are several other species of vireos through the United States, 


\section{Basket Makers, the Vireo and Oriole 185}

but all bear a close resemblance in size and color and nest similarly. The Red-eyed, White-eyed, and Yellow-throated Vireos are found in the East, while Cassin and Least Vireos are common on the Pacific Coast.

\section{THE ORIOLE FAMILY}

The Oriole may be recognized by the brilliant colors of his dress, and his pleasing, rollicking song. His length is about eight inches. $\mathrm{He}$ lives on insects, larvæ, plant-lice, and sometimes eats fruit. He is known as an architect because of the well-woven, hanging nest he builds generally in the trees that border the sidewalks.

Baltimore Oriole (Icterus galbula), Hang-nest: Male, head, throat, and upper part of back, black; wings, black with white spots on edges; under parts and rump, orange or orange-red, the intensity of color varying with age and season. Female, paler and back tinged with olive; below, dull orange. Lives in eastern United States to Rocky Mountains. Migrates the last of April and reaches the northern states about the second week in May. Builds a hanging basket suspended at the end of a swaying branch. Eggs, four to six, whitish, scrawled with black and brown lines.

Bullock Oriole (Icterus bullocki): Replaces the Baltimore from the Rocky Mountains to the Pacific. Slightly larger than above. In the male, the orange extends to the side of the head, neck, and forehead, leaving only a narrow black space on the throat and a black line through the eye. Habits identical. 

PHOEBE 


$$
\text { - }
$$




\section{XVII}

\section{PHCBE}

7 HERE were plenty of other birds building new spring homes about me, but Phœbe (Sayornis nigricans) occupied more of my attention than all the others. Perhaps it was because he was so retiring and had such a quiet personality. There is as much difference in birds as in people. When a new neighbor moves into a community all eyes are upon him. Shall he be taken into fellowship? Will his friendship be desirable? Certainly I would expect a phœbe to be received cordially if gentility counted. But it didn't count in this case for the neighborhood had already been settled by linnets.

Just over the fence was a vine that covered our neighbor's trellis. It had overrun its quarters and crawled along the telephone wire up under the eaves. One morning I saw a phobe sitting on a rose stake. In a moment he flitted up under the eaves, and sat on the wire scanning one of the brackets. His tail was tilting in quiet excitement. He seemed to be looking for a home site, and the bracket under the eaves was the best kind of a place. But I have often been disappointed in finding the nest site I should select does not exactly suit the bird. However, I had great hopes that the phœbes would build opposite just to offset the noisy linnets or house finches.

In a few days there were two phœbes flitting back and 
forth from the rose stakes to the fence. Occasionally they flew up under the eaves and sat on the wire. Then I felt sure they would make their home just above the vine on the bracket. But they made no beginning of nest building, although they roosted on the wire at night. They flew about uttering plaintive "De-ars" as if they couldn't really decide.

Phœbes do not seem to look on the bright side of things. They have a pathetic, complaining note which would catch your ear any time among the general chorus of bird notes. It doesn't seem to be a complaint, however, but just their serious way of taking life. They never seem really joyous; they are alert and light in movement, but they lack the brightness of other birds-perhaps life is too full of business.

Day after day for more than a week the pair of phœbes inspected my neighbor's eaves; then one morning I saw a pair of linnets nosing about in the vine just below the wire where the phœbes roosted. The phœbes saw them, too, and straightway decided to build a nest on the bracket, for they commenced carrying mud and straws. But they had waited too long. The linnets needed but one look, for the thick vine was just suited to their needs. Then when I saw the female linnet come with a string I knew there was trouble in the air. But to my surprise things did not come to a crisis till three days later.

The phœbes were just beginning the walls of their home. One of the birds was at the bracket when the redheaded linnet and his mate arrived. Without a second's pause there was a dash of red and gray and a whirl of black and white. I heard angry shrieks and frightened 
cries as a couple of feathers wavered down to the grass. Of course the phœbes would stand no show with the linnets. The phœbes were peaceable while the linnets were bold and impetuous, noisy in joy as well as in anger.

The linnets continued with their house as rapidly as possible, while the phobes sat around and watched most of the time. For several days they didn't add any to their home, yet they couldn't give up the idea of abandoning their site on the bracket. Late in the afternoon, after the linnets ceased working and had gone to bed, the phœbes were always there flitting about the rose stakes and the fence. Then in the dusk they would flutter up to the wire under the eaves and go to sleep close to the usurpers' nest. I looked for the tyrants to come out and forbid the phœbes sleeping so close to them, but they didn't. It was perhaps too much trouble for them to stir out after their early. bedtime.

Before long I knew the phœbes had taken up another home site, for they stayed away most of the day and only returned in the evening to roost. Then later only one of them, the father I took it to be, came to roost on the wire. I watched every evening, but he always slept alone.

I became curious as to where the mother phœbe had her nest, and I watched for several days but could not see where the father went or where he came from. But one day, while crossing through a small clump of trees, I saw one of the phobes snap up a butterfly and fly over toward a deserted cabin. No one had occupied the cabin for several years I thought, yet when I got there I found it inhabited by two families. At the back, just under the shelter of the overhanging shingles, the phœbes had plas- 
tered a mud nest, and now it was heaped up full and overrunning with a family of five children. Around to the front of the cabin I heard a wren singing, and I rounded the corner just in time to see him pop under the shanty which was built on the side hill; the front part of the foundation was three feet above the ground. Getting down on my hands and knees I crawled under and looked about the beams. On a cross-board in the corner were the nest and five eggs of the wren. With the phœbes in the rear, and the wrens lodged in the front of the cabin, there wasn't the least interference, and the place was much more interesting to me than before the original owners moved out.

The back of the cabin sloped down to a height of seven feet from the ground, and it was pushed close up against the side hill; we could stand on the slope and look right into the phobes' nest. The mud nest was plastered on the side of the wall as an eaves swallow builds his nest. With the mud the phœbes had woven in straws, rootlets, and horsehair to keep the structure from crumbling. Then the cup was lined with soft grasses.

I was amused to see how the phœbes had built. There were five different places where they had started to build and had plastered a few wads of mud on the wall. It seems they had selected one spot when they first started, and as all the boards looked very much alike the birds got mixed in the location when they returned each time; but they had not wasted much material, for after a few trials they had the spot fixed in mind and both deposited the mud on the same board. It looked to me as if they had stood off and thrown little balls of clay against the 


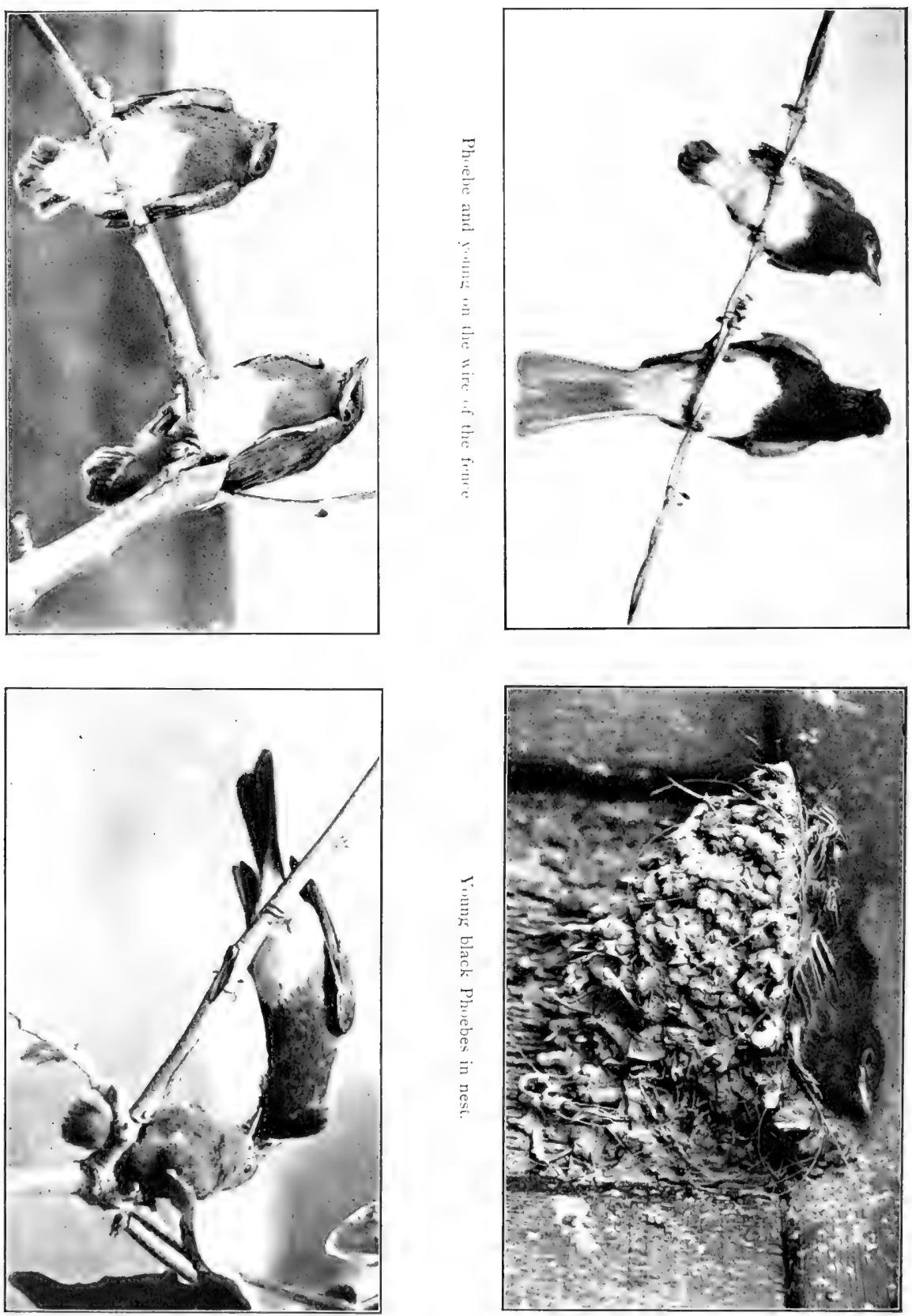
wall, for the boards were covered about the nest with small spatters of mud. But this likely came from the birds shaking their bills and flipping the mud off while building.

Both the mother and father fed the nestlings. They often brought in large butterflies which were fed, wings and all, to the children. The father phobe seemed the tamer of the two. A nearby fence post was his favorite perch. He would jump into the air and glide closely to the ground, a sharp click, a turn, and a graceful curve back to the post. "Pee-we-e! Pee-we-e!" he would say, as he teetered his loosely jointed tail. He seemed to talk as much with his tail as with his mouth, for it was always wagging. I often wondered that it did not get tired and fall off, he bobbed it so much.

I loved to watch phobe for he had such an air of grace and ease, he was so light and quick on the wing. The highest accomplishment of a bird is its power of flight. In this it differs from the other creatures except the insects and the bat. The wing of the bird is built with the minimum of weight for the maximum of strength. The bones and the quills are hollow, and the feathers are composed of the lightest filaments joined together by minute hooks.

The problem of flight seemed the simplest thing in the world to phœbe, yet it has taxed the brains of the wisest men to explain. The solution, as some one has given it, is that the bend in the wing feathers forms a hollow under the wing when it is spread. The downward motion of the wing forces the bird up. But this alone would not enable the bird to move forward. The muscles and the bones of the front end of the wing are strong and rigid. 
The back end of the wing, or the ends of the feathers, are soft and flexible. The air, catching under the inverted cup of the wing, escapes readily from the back end. This tends to lift the ends of the feathers, or push them forward out of the way, and the movement, repeated with rapidity, causes flight.

This seems the best explanation of the flight of birds. Yet each family has a distinctive flight of its own. A good ornithologist can tell a bird by its flight, just as a person may tell his neighbor by his gait. The crow always flaps along in a slow lumbering way. The flicker opens and closes his wings in long sweeps, similar to the wavy flight of the goldfinch, which often twitters when flying. The swallows skim along with exceeding grace and ease, while the swifts fly like bats, short and jerky in movement. A quail or pheasant flushes with rapid beating of wings, making a loud whir. The hawks, eagles, and buzzards generally soar high in the air, gliding around in wide circles. I have never seen phœbe fly high or far at a time. His business is to stay about near his home, and he is continually watching and snapping up flies.

One evening, a few days after I found phœbe's nest in the deserted cabin, I was sitting at the window when I heard the father calling excitedly in the back yard. I went out and there he had two of the young phœbes, one on the clothes-line and one on the woodshed. He was trying his best to tell them just what to do and how to do it. Soon he flew up to the wire under the eaves and then back again, telling his children that this was the best place to sleep for it was where he always spent the night. The father had persevered to the end and won his place under 
the eaves, for now the linnets were gone; the young had left the nest in the vine and set out for themselves. It took such an amount of coaxing and scolding for the father phobe to get his babies up to the roost, but the three were finally cuddled together on the wire. This was the father's first choice for a home, and I imagine either he or some of his family will return early next spring and take up a home on the bracket under the trees before the linnets arrive.

\section{THE FLYCATCHER FAMILY}

A little observation will enable one to recognize the birds of this family from their habit of perching on a fence or dead twig with wings and tail moving up and down, ready for instant action; suddenly the bird dashes into the air, catching an insect with a quick turn and a click of its bill and returns to its perch. The birds of this family have no elaborate song, only a harsh chirp or a varying twitter or whistle. The bill is broad and flattened, with bristles at the base. The Kingbird or Beemartin is about eight inches long while the Wood Pewee is six and the Phœbe about seven inches.

Phœbe (Sayornis phobe): Male and female, upper parts, olivegray, darker on head; under parts, whitish, tinged with pale yellow. Lives throughout eastern North America, where it is common from April to October. Nest made of mud and moss, bracketed on the side of a rock or under a bridge. Eggs, from three to six, pure white, sometimes spotted with brown about larger ends.

Black Phœebe (Sayornis nigricans): Male and female, entire plumage black except belly, which is white. Webs of outer tail feathers, whitish. Habits same as above, but resides on Pacific Coast. 



\section{A PAIR OF COUSINS-ROBIN AND THRUSH}


- 


\section{XVIII}

\section{A PAIR OF COUSINS-ROBIN AND THRUSH}

KNOW of no other two birds so near akin that are 1 so opposite in character and disposition as the Robin (Merula migratoria propinqua) and the Thrush (Hylocichla ustulata). As scientists distinguish birds there is not much difference because both are thrushes, except that the robin is attired with much more show, while the thrush has a modest brown dress. But this is the smallest difference. In other ways they are distinctive types. For spunk and audacity the robin has it over most birds. The thrush has none of this boldness. He flits around in the shade trees and on the ground as if he were trying to keep hidden. He sings from a thick clump, the robin from a tree-top. The life of the thrush is pitched in a low key. His best song is a vesper hymn with a strain of sadness through it all. The robin has a gayer disposition; he is at his best in the rollicking song of the morning.

Both birds nest about my home, the robin in the orchard, the thrush in the fir thicket beyond. When I looked into the nest of the robin it made the owners beside themselves with anger. They dashed at me. "Help! Murder! Get out of here or we'll knock your head off!" they yelled. When I crawled into the thicket where the thrush had her home she was more offended 
than frightened. She held her dignity and looked at me with an air that said, "This is my home: you are intruding."

Of the eight hundred species of North American birds, the robin is the most widely known. No matter how limited a boy or girl's knowledge is about birds, he knows the robin when it arrives in the spring and begins to hunt worms on the lawn.

Perhaps no bird is so closely associated with our everyday life as the robin. He takes his chances with the cats about the dooryard. He is a rural life bird, but he doesn't like the primitive forest. He can get better nest building material and better food wherever man is, and he stays near by some house. He likes a lawn in the springtime, for it always holds a good supply of worms. Give a robin plenty of lawn in the spring and a good cherry orchard in the summer and he asks for nothing else, and you can't get rid of him. And he makes a picture in the field. How his ruddy breast shows against the green! He hops along for a few steps, and suddenly stands erect and still, as if thinking. Then his head turns to one side in a pert way as he examines the ground and listens. Down into the earth goes his bill, and he sits back and jerks a long worm from its hole.

As the robin is widely known because of his distinctive size, dress, and habits, so the thrush is known for his singing. "If we take the quality of melody as the test," says John Burroughs, "the wood thrush, the hermit thrush, and the veery thrush stand at the head of our list of songsters." Every bird lover has his favorite songster, and it is often difficult to say whether the song of one 


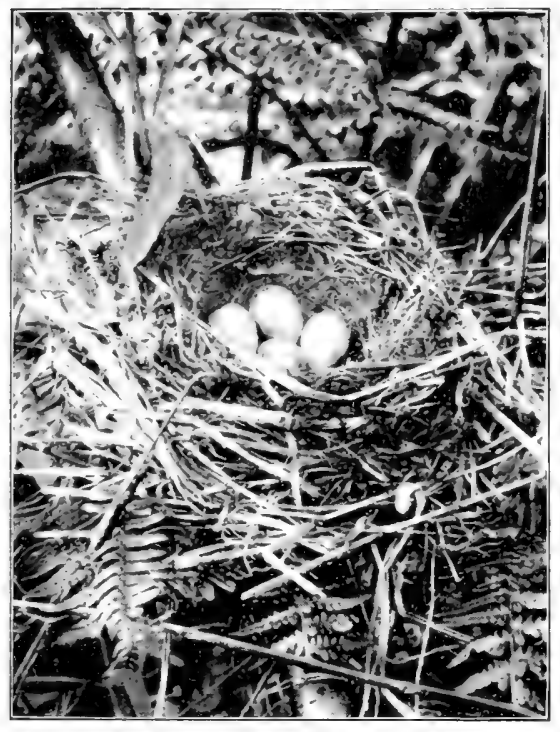

The Thrublis nent among the ferns.

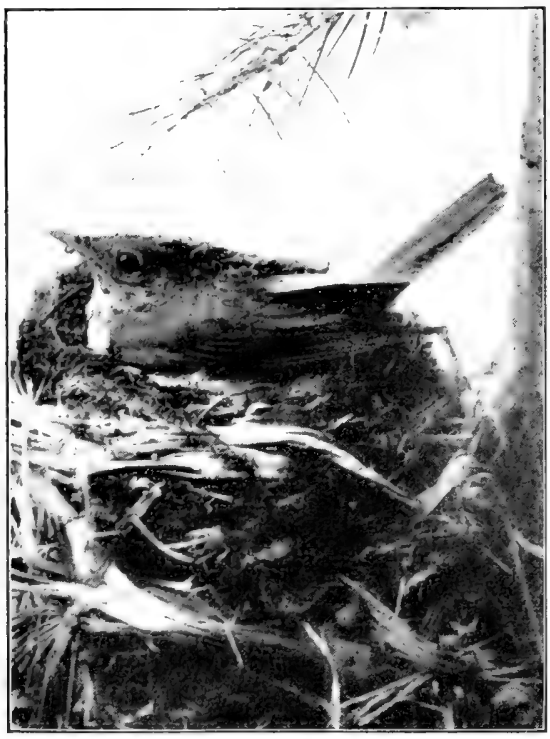

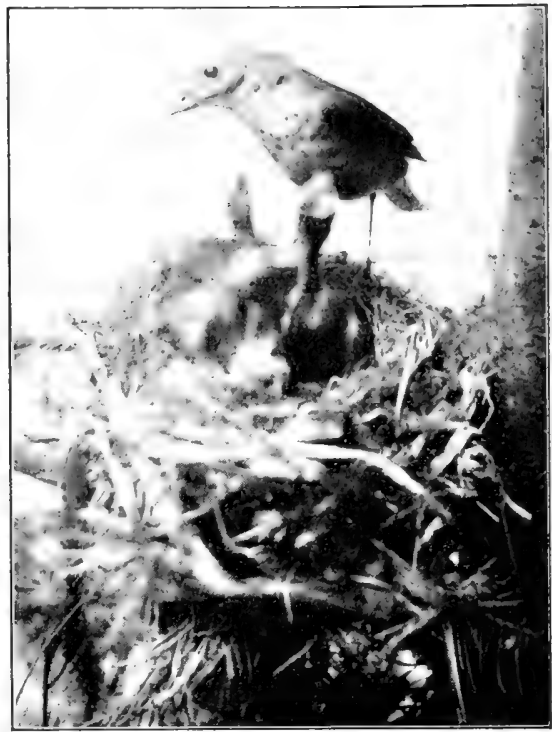

The 'Thrush mother at the nest edge.

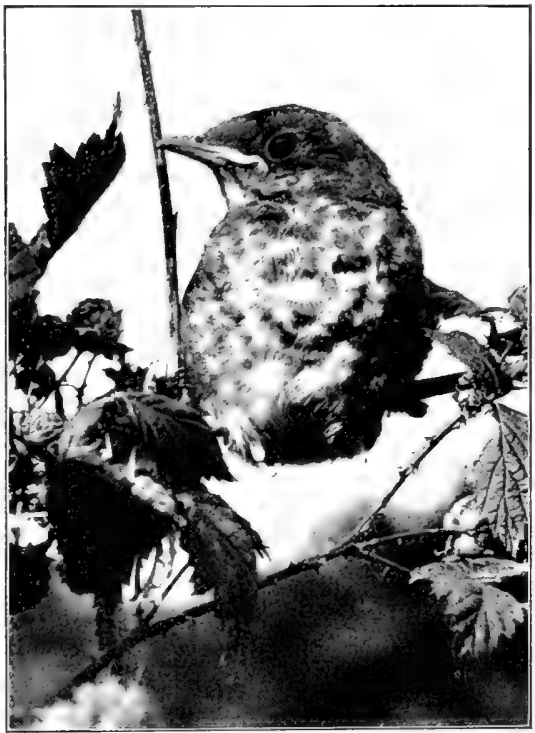





\section{A Pair of Cousins-Robin and Thrush 20r}

bird surpasses that of another, because bird songs are largely matters of association and suggestion. At specific times and places, or under certain mental feelings or emotions, I have felt bird music sink into my memory to remain a lasting pleasure. I can never forget the song of a winter wren $I$ heard in the very heart of the forest. I had tramped the whole day along the lonely trail, and the heavy woods seemed so deserted of birds that I had heard the call notes of only two or three rare species. I dropped down to rest a few moments and was greeted by a sprightly but plaintive little song, that seemed almost lost in the primeval solitude of the woods. It was the winter wren.

Few songs have thrilled me more than the carolling of the robin at sunrise on a crisp spring morning as I have set out for a walk in the woods. Yet this is not my favorite song. The thrush has a richer, fuller melody. His song is one that ranges the whole scale of pure. emotion. And it comes best about dusk from the shaded cañons or the dark, tree-covered lawns.

The nest in the fir thicket beyond the orchard was a typical thrush home. When I crawled in under the thick, low-hanging branches of the fir saplings I almost put my hand in the nest. The mother did not flush till I shook the limb, and then she slipped through the branches and gave a low whistle that brought her mate. The nest was made of moss and lined with leaves. I have never found a thrush's nest that was not built largely of moss. Moss is as essential to the russet-backed thrush as mud to the robin and lichens to the hummingbird.

Whenever I visited the thrush's nest I met both the 
father and the mother. They flitted about the trees, watching me in silence. They were always shy, and to me the shyness was the truest indication of the fine natures they possessed. They did not relieve their feelings by a great show and fuss as the robins did. The robins were always unnecessarily fussy and noisy. They are of plebeian stock; the thrushes are real patricians. Each time the thrush mother came with food for her young I saw her linger at the nest edge. Many bird mothers are away as soon as they have fed their young, but the thrush never failed to examine her nestlings, and I often saw her sit for several minutes at a time looking at her babies and caressing them with a real mother's love.

There are many tragedies in bird and animal life, but we rarely come upon them. How often do we see a bird sick or dying? The end is generally tragic and not from natural causes. The weak fall as prey to the strong, the sick bird dies from a cat or some other animal. One day I was watching a pair of yellow warblers in the orchard that were flitting about the vine-covered fence. I think they were building a nest or just about to build in the vicinity. The first thing I noticed, the male paused on the fence, fluttering his wings. His mate flew down beside him. He tried to fly to a limb of a tree near by, but fell short and wavered to the ground. The wife was right beside him and chirping all the time. I went nearer for a closer view. He lay flat on his back, writhing in pain. I stooped to pick him up, for he was dying. His wife was on the fence, scarcely a yard from my hand, fidgeting and calling to him. He died in my hand. I laid him back on the ground; his mate was by his side in an instant, and now 


\section{A Pair of Cousins-Robin and Thrush 203}

as speechless as I. She didn't cry; they say birds can't cry, but it was sadder for all that. It was dumb grief. She stayed about all day, waiting for her mate. I buried him by the fence where he fell, stricken by I know not what.

Birds sometimes meet with accidental death. I once saw a swallow fly against a telephone wire with such force that the bird was killed instantly. Later in the season, after the thrushes were grown, I found the body of a thrush hanging to the barb of a wire fence down below the orchard. The wire ran straight across the top of a zigzag fence, and the bird, in full flight, had just skimmed the top of the rail to go full force into the wire before it was seen. The barb had caught in the neck, and the force had swung the bird's body over the wire from below, locking it in a death-grip.

Last summer when I went out through the orchard to examine the trees and see how many bird homes I could find, I found many of the same tenants back, but for some reason not as many robin families as usual. I found only seven robin nests, while these cherry trees generally feed about a dozen broods as well as furnishing a stamping-ground for all the neighboring robins half a mile around.

Two years ago an old robin built in an apple tree two rows over from the cherries. This year he planted his nest in the main crotch of the best Royal Ann cherry tree. The minute I swung up into the branches to get some fruit I was pounced upon by two angry robins. In two minutes they raised such a cry of "Thief! Thief!" that all the birds in the orchard were scolding me. It looked 
as if I were about to lose my head for taking my own cherries.

In a plum tree a short distance away I found a nest that had been vacated a few days before by a brood of four young robins. Out of this I picked twenty-seven seeds. On the ground below the nest were a whole handful of pits. But no one can begrudge a few cherries in payment for the horde of insects and worms destroyed by the birds.

I was standing in the back yard watching a robin that came for string to build her nest. I had wrapped a piece several times about a limb to see whether the bird would use any intelligence in unwinding it. I have always been skeptical of some of the stories that have been told of birds reasoning. For example, one writer tells of an oriole that took a piece of cloth and hung it on a thorn so the thread could be pulled out. When the cloth came loose, he said the bird refastened it. Again, he has the bird tying knots in the string to keep the ends from fraying in the wind or tying the sticks together to make support for the nest. But these are not bird actions: they were evolved out of the fertile brain of the writer.

As soon as the robin spied the string I had placed in the tree she thought it good for her nest. She lit on the branch and took it in her bill, and, finding it caught, she gave it a hard tug. Twice she started to fly away with it, but she pulled up with a sharp jerk. She could see and reason no further than the end of the twine. Had she unfolded one or two wraps about the limb, the whole would have come loose. Again and again she took a try at that string with the same success, until she got it tangled 


\section{A Pair of Cousins-Robin and Thrush 205}

about some of the leaves. Then I loosened it and she carried it away. Birds do not know how to use string, for it is new to them. They sometimes get tangled and hang themselves.

Robins often show very great difference in the matter of selecting a site for a nest. I saw one nest built on an old rail fence a foot from the ground, another in the side of an old stump, another under a porch, while the great majority of robins will select a tree near a house and place the nest in a strong crotch. The nest is generally built with coarse sticks and strings on the outside and a good cup of mud with an inner lining of finer grasses. Yet I have sometimes found robin nests with hardly a bit of mud.

Each species of bird has a peculiar way of building a nest that differs from that of every other species. Among many of the common birds one can generally tell what bird built the nest by a glance at the exterior and the position in which it is placed. The vireos and the orioles build a hanging nest, robins and jays and crows a bulky nest, the warblers build a neat deeply-cupped structure, the grosbeak has a thin framework that you can see through, and the cuckoo and the dove make only a rough platform for a home.

Birds have a good deal of intelligence when it comes to knowing their friends and enemies. One of our neighbors had a robin nesting in the orchard, and it became very fearless. Whenever the cat went near the nest the robin darted at it and clipped it on the back of the head and ears. And the animal would beat a hasty retreat, for it had been taught not to catch birds. 
In another yard where the blackbirds nested in the cypress trees they grew so bold as to be almost vicious, for they had nested there so long that they thought they owned the place and could exclude all intruders. If a strange person went near the nests while they contained young, the old blackbirds began to scold and swoop from the upper limbs, giving the intruder a sharp rap on the head. It furnished us lots of fun to see a strange dog begin to nose around. In an instant he got a clip on the ear and then another. The birds struck, and were away before he could retaliate. He would retreat, and the minute he turned his back the birds were after him, nipping his ears. The faster he ran, the better the chance for them to strike, till they bustled him out of the yard and down the street in a hurry.

In the spring and fall the robins often assemble in a large grove every evening and roost together. I discovered one of these robin roosts at Berkeley, California. The robins assembled each evening in a large eucalyptus grove and spread out over the country to forage during the day. This was the last of February and the first of March. Then the birds began to go north. Later in the spring I have seen them do the same thing when they reach their breeding grounds in Oregon. They like a community life.

One evening I went down to the eucalyptus grove to count the robins. I went at five-thirty, but was not early enough, for the grove was then well populated with robins. They were coming in singly and in small flocks. In ten minutes I counted over three hundred coming from the west. Then I counted from the south, and over six 


\section{A Pair of Cousins-Robin and Thrush 207}

hundred arrived in ten minutes. They kept coming continually from all directions until a quarter after six, when most of the birds were back. The grove was alive with them just before six o'clock. They kept up a continual clatter, flying from tree to tree, as if talking with their neighbors over the events of the day. In the centre of the grove, the chirping and fluttering were so loud as to shut off all sounds from the outside.

Many of the robins came from a long distance, for they flew high. Sometimes as I watched I saw them drop out of the sky. They were often directly above the grove before they seemed to see it. I saw the tiniest speck in the blue, and it would grow rapidly larger until the robin dropped into the grove. Sometimes I saw the birds fly clear past the grove before they seemed to recognize the place; then they would turn, fold their wings, and drop headlong. One day, when it was very windy, they flew low, just over the housetops. Many would come in, beating their wings and going very slowly against the wind, as if all tired out.

For several evenings I tried to count the number of robins that came into the grove. I estimated over six thousand were sleeping there every night.

I thought there would be a grand chorus in the morning when all these birds awoke, so I went over before daybreak one morning. The robins awoke at the first indication of dawn, and they began leaving the trees immediately. There were no songs, only a few robin calls as the birds departed in singles and in small flocks, as they had come the evening before. And by five-thirty the grove was vacant again. 


\section{THE THRUSH FAMILY}

This family contains the best of our American song-birds. The colors are generally brown, the breast speckled, especially in young plumage. The thrushes have moderately sharp and slender bills. They live on insects, berries, and fruit. Common throughout the woodland parts of our country. The robin is about ten inches in length, while the wood thrush is two inches shorter.

American Robin (Merula migratoria): Male, above, olive-gray; head, wings, and tail, blackish; throat, black, streaked with white; breast, brickred; white eyelids. Female, paler throughout. Common through eastern United States, where some stay all year; migrating flocks come in March and leave in October and November. Nest in crotch of tree generally, made of sticks and plastered with mud. Eggs, four in number, greenish-blue, unspotted.

Western Robin (Merula migratoria propinqua): Name applied to species on Pacific Coast, but bird is not distinguishable from above.

Wood Thrush (Hylocicbla mustelina): Male and female, head and back of neck, rusty or golden-brown, fading to olive on the rump and tail; under parts, white, sprinkled with dark brown spots. Lives in the states north of Virginia, Kentucky, and Kansas, where it stays from early May to October. Nests in low trees and bushes. Eggs, four in number and like the robin but smaller.

Wilson's Thrush (Veery) and Olive-backed Thrush, somewhat like the above in looks and habits; may be found throughout eastern United States.

Russet-backed Thrush (Hylocicbla ustulata): Male and female, above, olive brown; breast, light colored with dark spots like the above species. Lives on the Pacific Coast. 


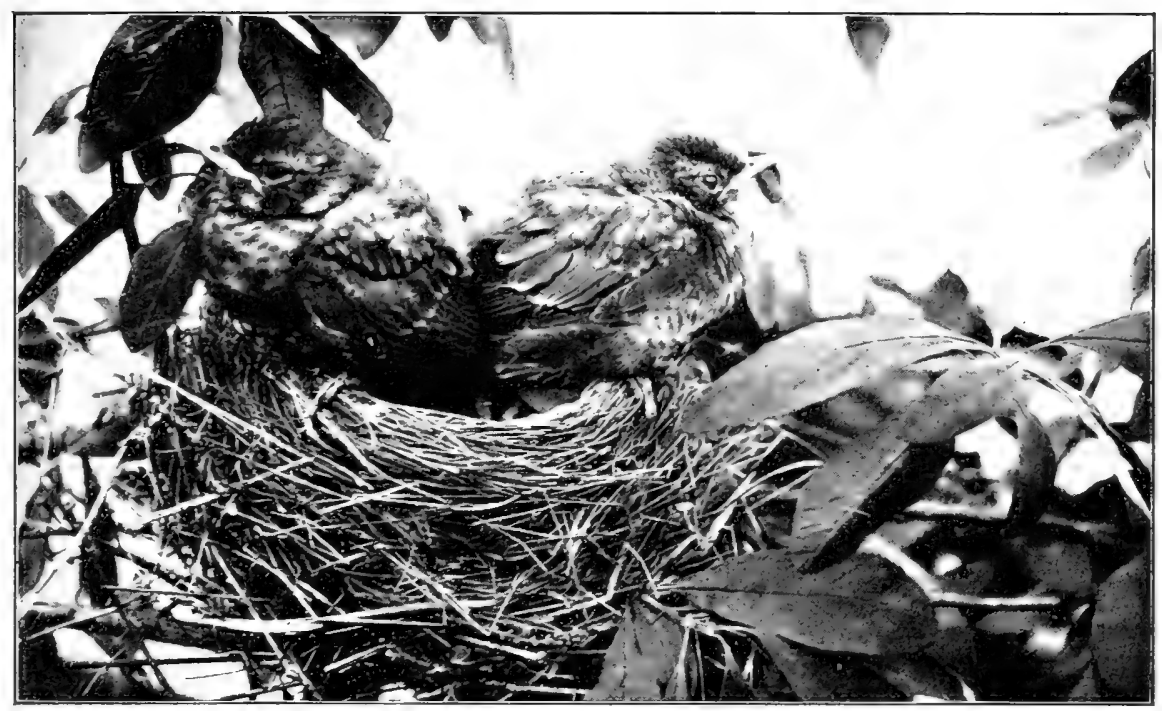

Young Robins at home

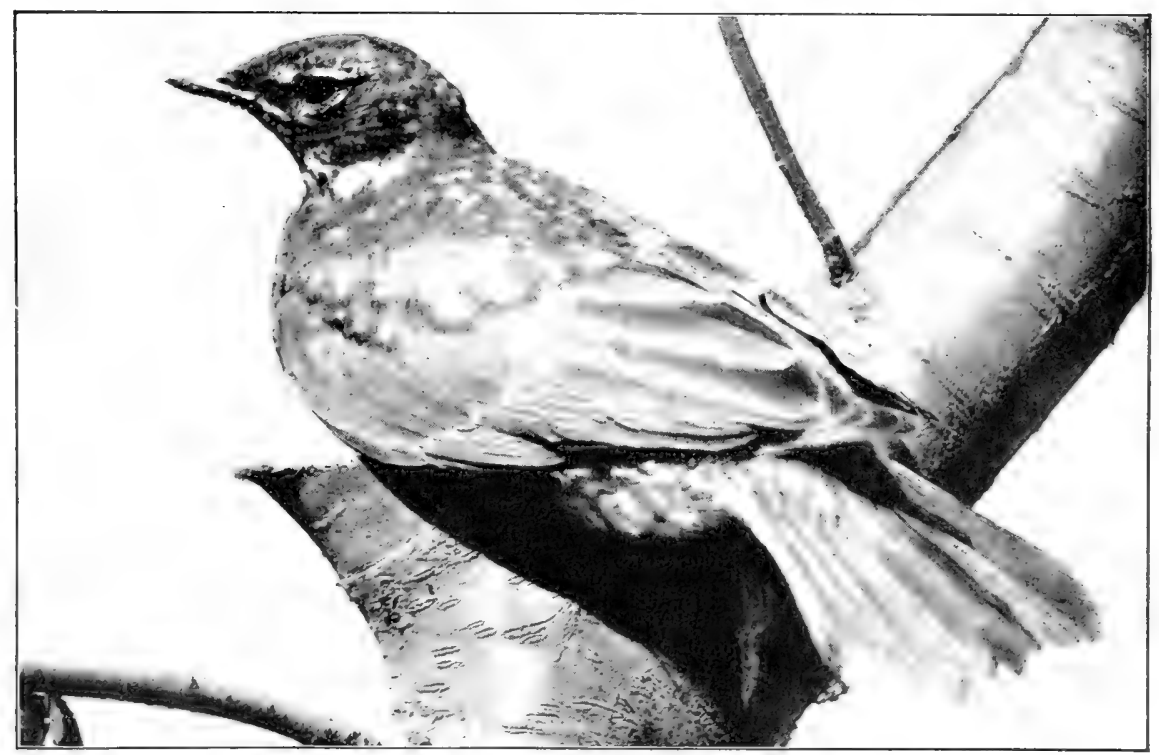

A Robin in the cherry tree. 

GULL HABITS 



\section{XIX}

\section{GULL HABITS}

T VERY fall when the waves begin to beat heavily along the sea-shore, a white-winged fleet sails into the rivers and bays to winter. When most of the other flocks have gone to the southland, this feathered fleet skims about the wharf-lined water front. These are the Gulls, and they add life to the landscape as they float and sail about, just as the white-sailed boats of the summer skim about the waters of the inland harbors.

The gull comes not for pleasure alone, he comes because it is easier to find a living about the city than on the open sea. He pays for his existence in the amount of garbage he picks up. He skirmishes the river for dead fish, putrid flesh, and waste stuff of every kind. If his food supply runs low on the river, he hunts overland. If the gulls are fed along the water front, they become very tame, and return regularly every day for their dinner.

The gulls are quick to learn that they are protected about the harbors, and they become quite fearless in their search for food. They will often come almost within arm's reach, yet these same birds are likely to be very wild when they are not in the harbor limits, where the strict regulations protect them. Only a few years ago the gulls were allowed to be killed without limit, but now they are protected under the different state game laws. When- 
ever a gull is shot and falls to the water the other gulls crowd about either through curiosity or sympathy, and for several moments they will hover over a fallen comrade. Hunters took advantage of this trait, and often large numbers of gulls were slaughtered wantonly or for their plumage, which was used for millinery purposes.

One summer we visited the native haunts of the gulls and climbed about their homes on some of the rock islands off the Pacific coast. We found them even more picturesque here, as they flashed their white wings against the rough brown rock, than they are about the bays and rivers. We climbed the rocky slopes to the crevices where these birds had carried a few handfuls of grass for nests. We saw them building on almost every suitable table ledge. But the largest number of nests were scattered about the green slopes on the top of the rock. Here each gull scratched out a little hollow and lined it with dry grasses. Two or three eggs of greenish hue, blotched with brown, in each nest, were so closely matched with the green and dry grasses that we had to watch at every step to keep from treading on them.

Later we found the top of the rock fairly alive with mottled-gray sea-gull chicks. A pair of these chaps are about as interesting as anything I've seen in the bird line. They show little fear, but there is generally a look of surprise in their eyes when you stoop to pick them up. These young gulls retain their mottled dress until after the first year. The snow-white breast and pearl-gray coat are only worn by the more mature birds. The brownish-looking fellows perched along the docks of the city are not a different species; they are immature gulls. 

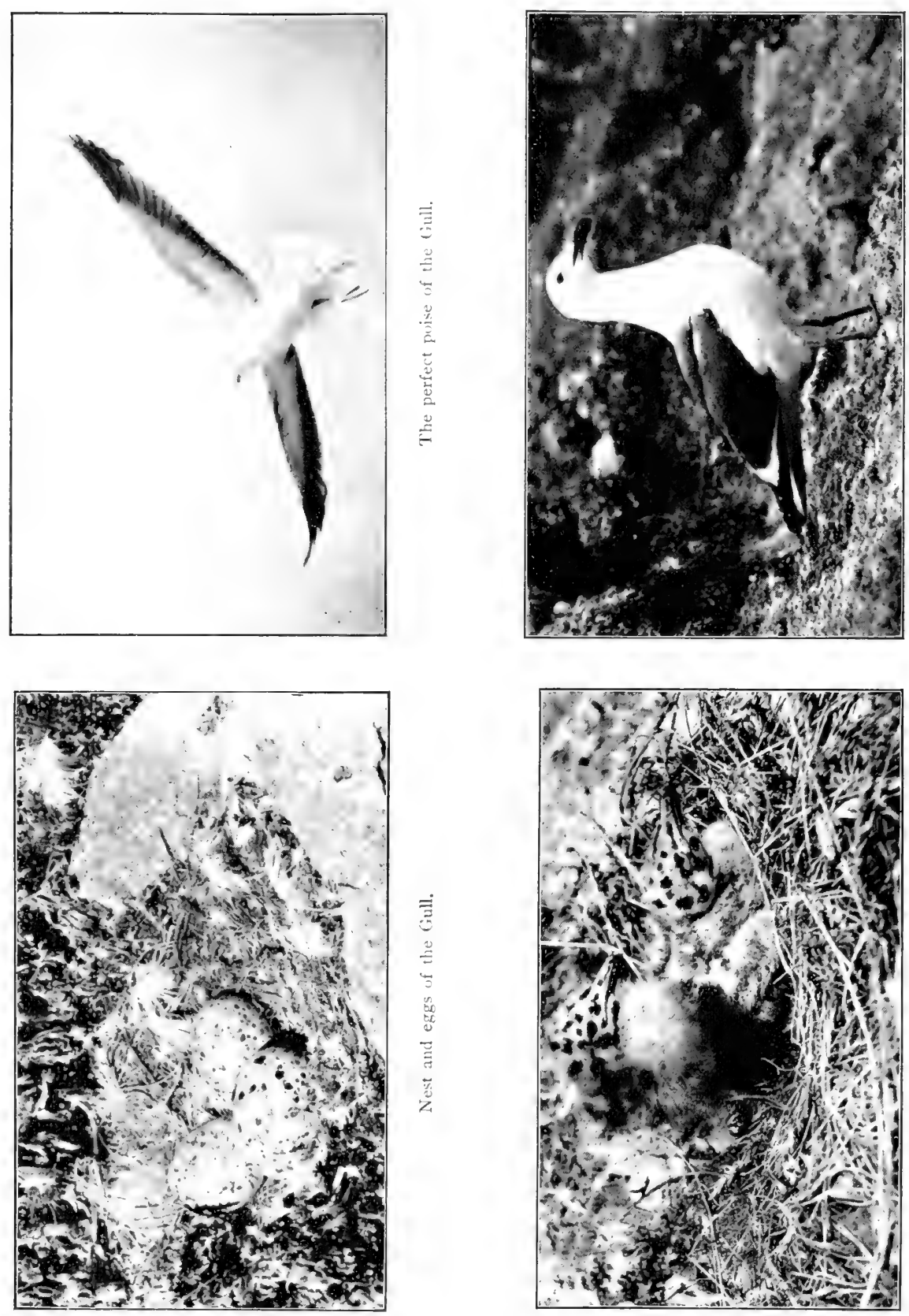

About the rock where the gulls lived we had a splendid opportunity to study the home life of these birds. We soon discovered that the greatest anxiety of the parents seemed to be to keep their children crouching low in the nest, where they thought they would escape observation, and would not run away and get lost among so many neighbors. I saw one young gull start to run off through the grass, but he hadn't gone two yards before the mother dove at him with a blow that sent him rolling. He got up dazed and started off in a new direction, but she rapped him again on the head till he was glad to crouch down and lie hidden. It seemed also to be the duty of the parents to beat their neighbors' children if they didn't stay at home, for each mother recognized her own chicks largely by location.

He who would study the art of aerrial navigation, would do well to watch the gull's flight. I have often looked at these birds as they hang in the air, or move straight up in the teeth of the wind in the rear of one of the ocean steamboats. They poise, resting apparently motionless on outstretched wing. It is a difficult feat. A small bird cannot do it. A sparrow hawk can do it only by the rapid beating of his wings. The gull seems to hang perfectly still, yet there is never an instant when the wings and tail are not constantly adjusted to meet the different air currents, just as in shooting the rapids in a canoe the paddle must be adjusted every moment to meet the different eddies, currents, and whirlpools, which are never the same at two different instants. These gulls are complete masters of the air. A sail-boat can only tack against the wind. A gull, by the perfect adjustment of his body, 
without a single flap of the wings, makes rapid headway straight against the wind. I've seen one retain perfect poise and at the same time reach forward with his foot and scratch an ear.

The gulls are more common along the Pacific Coast than along the Atlantic. All through the West the gull is a versatile bird, for although he is born for the water, he seems to be as much at home hunting about the fields. as on the ocean. In Utah the gulls that nest about the Great Salt Lake fly all through the surrounding country and visit the beet fields, where they catch crickets, grasshoppers, and cutworms. Mice are very plentiful in the alfalfa fields, and when the land is irrigated and the water drives these pests from their holes the gulls are always on hand and snap them up as soon as they appear. The gulls are sacred in Utah; they are of so much value to the farmers that they are protected in every way.

In southern California and Oregon I have watched flocks of gulls leave the ocean and rivers at daybreak every morning and sail inland for miles, where they skirmish about the country and hunt a living for themselves. I have watched a flock of them follow the plough all day long, just as the blackbirds do, fighting at the farmer's heels for angleworms. Others rummage daily about the pig-pens and gorge on the offal that is thrown out from the slaughter-houses. But I have never seen the gulls spend the night about these places. Toward evening they begin to collect in bands and sail back to the ocean, where they can bathe and sleep. If any bird is useful to man, the gull is certainly of great economic importance as a 


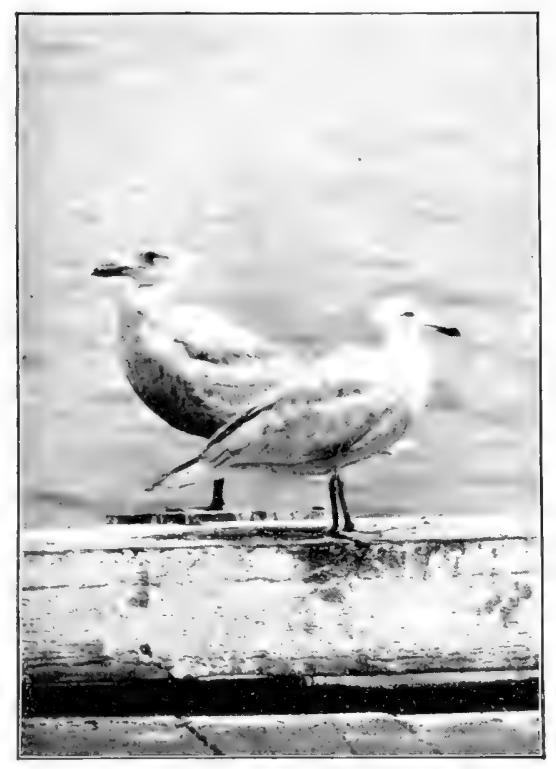

A pair of Gulls on the wharf.

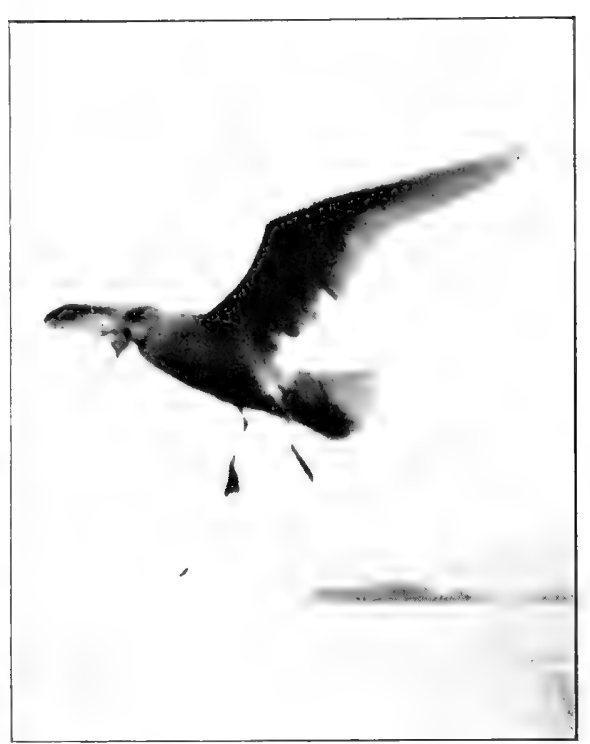

(iull just catching a bite that is thrown to it.

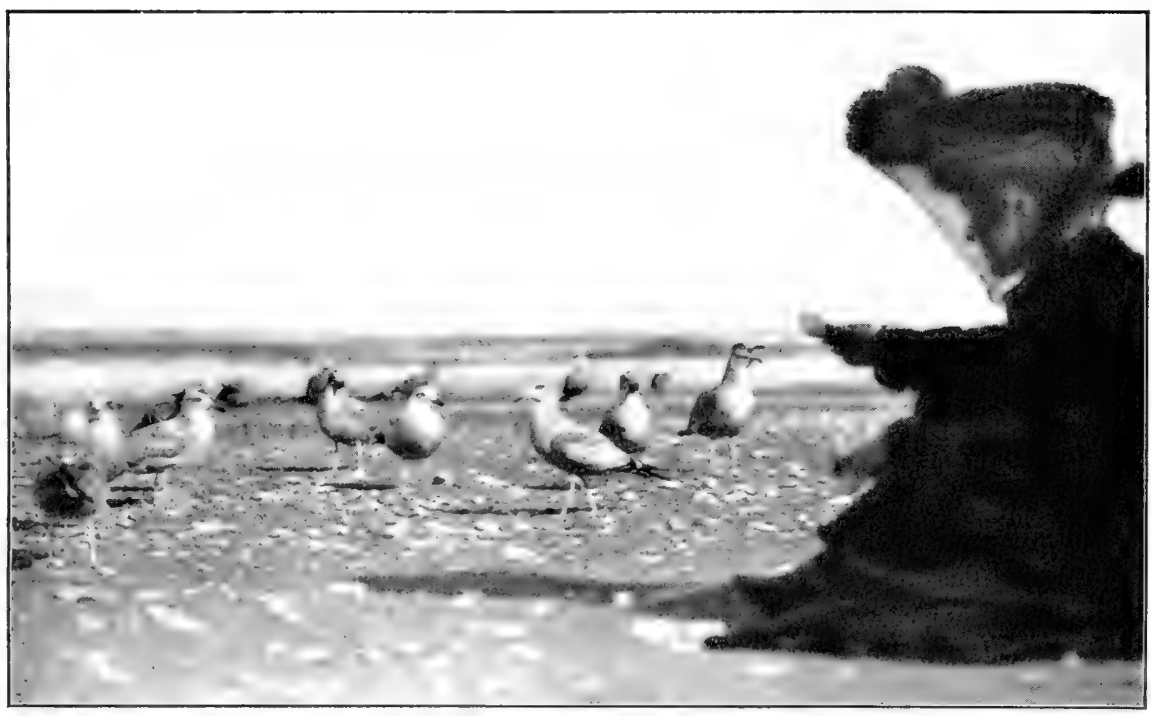

Tame Gulls about the beach. 
scavenger; three of them are equal to a buzzard, and ten equal to a pig.

In another way the gull shows his quickness to take advantage of opportunity. In southern California, where the gulls and pelicans feed together in the bays, the gull is a parasite, living on the labor of the pelican. Although heavy and clumsy in shape, the pelican is as expert as the kingfisher at diving. From a height of thirty or forty feet, he drops like a plummet into a school of small fish and rises to the surface with pouch filled with fish and water. As the diver stretches his neck and draws his bill straight up, the water runs out and the fish are left. The head is thrown back, and the whole catch is swallowed at one gulp. But the pelican does not fish for himself alone, for he is always followed by one or more thieving gulls.

One day, while standing on a wharf, I saw a brown pelican flapping along with a pair of gulls a few feet behind. A moment later the big bird spied a fish, for with a back stroke of his wing he turned to dive. He gathered speed as he went, and with wings partly closed and rigid he hit the water with a resounding splash. The lower mandible of his bill contracted and opened his pouch that held as much water as the weight of his body. $\mathrm{He}$ came to the surface and was in a helpless condition till the water ran out, and at this moment he was pounced upon by the swift-moving gulls, who snatched the fish and were away before the slow pelican could retaliate.

At another time I saw a band of a dozen pelicans following a school of fish. They rose from the surface, swung around till about twenty feet above, and two or three of them dropped into the water at a time. A bevy 
of twenty gulls were fluttering around to pounce upon every pelican that dove. The instant one disappeared and came up with fish he was surrounded by a bunch of gulls, each screaming to get a nose in the pelican's big fish bag.

We were interested one winter in studying the great flocks of gulls that live about San Francisco Bay. Every morning at eight o'clock the garbage is emptied at the long dock of the navy training station. The gulls about the neighborhood know this as an ordinary laborer knows the lunch hour. They flock around by the thousands. It looks as if some one had poked a stick into a hive of big feathered bees as the birds flutter about and fight for particles of food.

Protection has made these birds very tame. "Old Whitey" used to be known to every sailor on the Pensacola training-ship, and he showed up for meals as regularly as the bugle blew. He had his own perch on the bowsprit, and took bread or meat from the hand like any pet. There were always several others riding the anchor chain, waiting for scraps from the table. Many of the birds were very expert at catching morsels in the air, as they were often fed by the sailors. I have often seen them take a crust of bread in mid-air, rarely missing a catch.

The minute a new food supply is found anywhere about the bay, the news spreads in the gull world by wireless telegraph. A flock of half a dozen gulls will increase to as many hundred in an hour or so. You can't see just where they come from, but they come. When the steamdredger started to open the channel of the Oakland estuary a whole flock of gulls sailed in and settled at the mouth of the long pipe, which was belching forth a mix- 


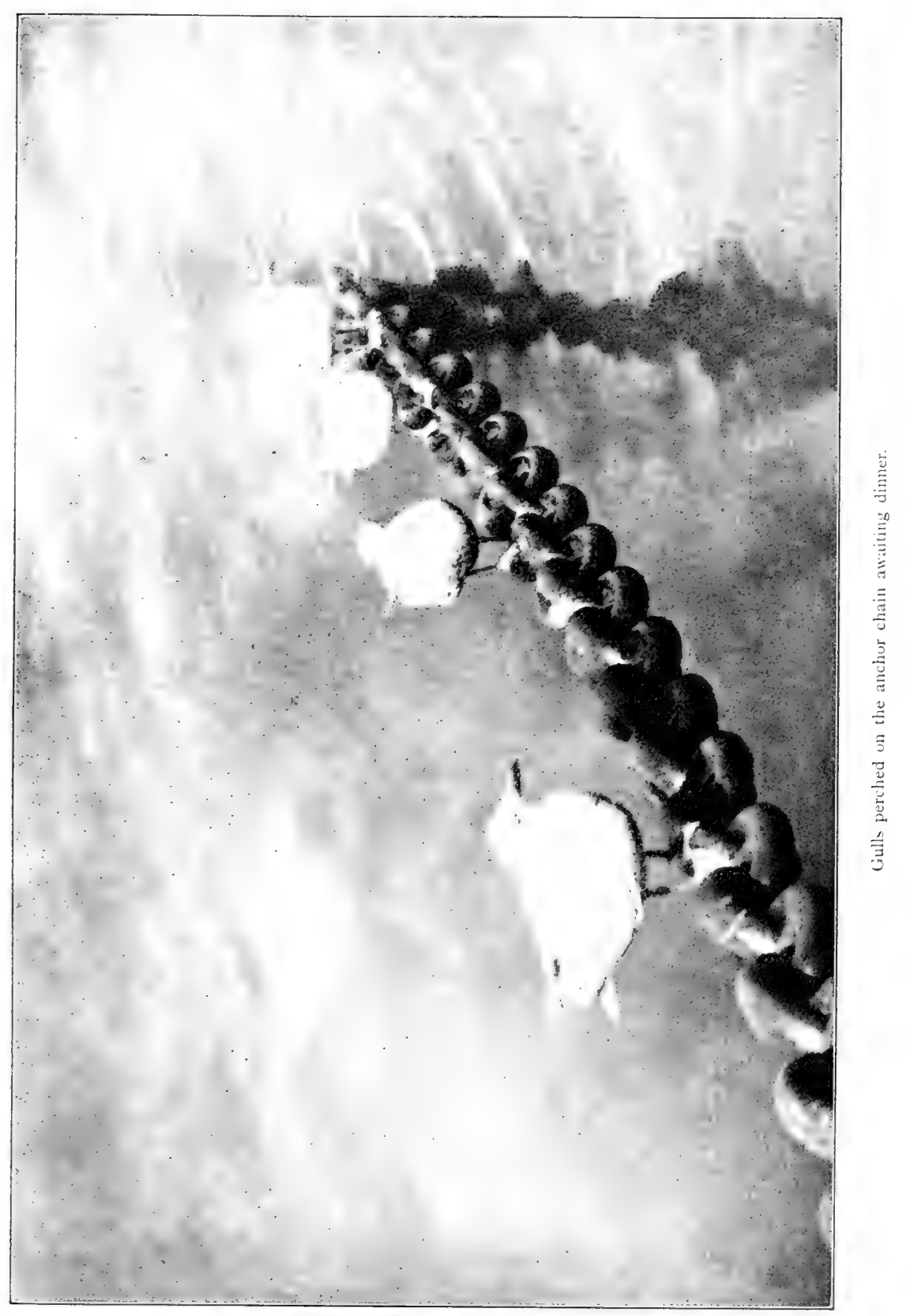




\section{Gull Habits}

ture of mud, water, rocks, and clams. It was as bad as a crowd of a thousand noisy newsboys. Such a shoving, clambering, flapping, grabbing! Every clam was gobbled up the minute it struck ground.

I have often seen the western herring gull act in ways that speak well for his sagacity. On several occasions I watched him open clams and mussels. His bill is unfitted for crushing the hard shell. I saw one gull grasp a clam in his bill, rise to a height of thirty feet, and drop it to the hard sand and gravel below. He followed it up closely, but it didn't break. He repeated the same performance over fifteen times before he was successful.

\section{THE GULL FAMILY}

The Gull belongs to the family of long-winged swimmers. They are experts on the wing and they swim lightly on the water. The gulls are common and easily recognized along the sea-coasts. They live on fish and refuse matter picked up about the harbors.

Herring Gull (Larus argentatus): Male and female, alike; back, delicate pearl-gray; head, neck, under parts and tail are pure white. In winter, the head and neck are streaked with gray; bill, yellow with red spot near end of lower mandible. Length, about twenty-five inches. Found throughout North America; winters about the harbors and retires to the rocks off the coast and to inland lakes to breed. Nest is a hollow on the ground, lined with grass. Eggs, two or three, from olive-green to brown, irregularly streaked and dotted with dark brown and blackish.

Western Gull (Larus occidentalis): Same as above, except the coat is slightly darker in color. Found on the Pacific Coast. 
IN A HERON VILLAGE 


\section{XX \\ IN A HERON VILLAGE}

$\mathrm{F}$ all the sights and feelings of a bird lover, the most lasting, perhaps, is when he first steps from the quieter wood scenes and suddenly emerges into the very heart of a busy bird town. The eyes pop as wide and the pulse beats as fast as that of a backwoods boy when he first walks into the very midst of a modern three-ringed circus in full swing.

Fifteen miles below my home in the heart of the fir forest is a village of two hundred houses. It has an area of about three acres. Every home is a sky-scraper. Not a single house is less than a hundred and thirty feet up, and some are a hundred and sixty feet high. The inhabitants are feathered fishers. They hunt the waterways of the Columbia and the Willamette for miles. Each owns his own claim, and there's never a dispute as to possession.

It takes the biggest reserve of nerve and muscle to reach this village, but one may sit on the wooded hillside far below and watch life there in full swing. From two to five brush-heap houses, the size of a wash-tub, are carefully balanced and securely fastened in the top limbs of each tree. Gaunt, long-legged citizens stand about the airy doorways and gossip in hoarse croaks. Residents are continually coming and going, some flapping in from the feeding-ground with craws full of fish and frogs, others 
sweeping down the avenues between the pointed firs with a departing guttural squawk.

One of the most risky and perilous pieces of work ever done in the tree-top was accomplished here in the tall firs in getting the nest and eggs of the Great Blue Heron (Ardea herodias). The photographer had selected the most "climbable-looking" stronghold in the heronry, where the nearest nest was a hundred and thirty feet up. But after the long, arduous ascent, he found that both nests contained newly hatched birds. Just fifteen feet away in the branches of an adjoining tree was a nest containing four eggs. To get this, the photographer strapped himself carefully in the branches and wrapped his legs about the trunk. With a rope he lassoed the broken end of a limb on the adjoining tree, and, by slipping the cord back and forth, worked the rope up to the trunk. A slow, steady pull and the tops of the trees bent closer together. The tension became stronger and stronger between the two trees, until at four feet it looked like a huge catapult that might suddenly be sprung and shoot the climber backward into space. In another instant an aërial bridge was formed in the treetop while the photographer secured his prize.

The heronries in the Oregon forests are pretty well protected from the raids of a bird-photographer by reason of their great height from the ground. For several years we hunted for a colony of these birds, where a good series of photographs could be taken. We never found one in Oregon, but we did discover one in California last summer.

Down in the swamp regions at the lower end of San 


\section{In a Heron Village}

Francisco Bay is a narrow wooded belt reaching out about a mile, and it is about two hundred yards in width. When we approached this thicket we saw the trees were well loaded with nests. We skirted the edge of the belt, looking for an entrance, but to our surprise each place we tried was barred with a perfect mass of tangled bushes and trees. We crawled through in one place for a few feet, but over and through all was a network of poison oak and blackberry that we could not penetrate. There was not the sign of a path. After two hours we went to the point opposite the largest tree and decided to push and cut our way through. The first few yards we crawled on our hands and knees, pushing our cameras or dragging them behind. Unable to crawl further we had to clear a way and climb a ten-foot brush-heap. For a few yards we ducked under and wiggled along in the bed of a ditch in the mire to our knees. I never saw such a tangled mass of brush. Fallen limbs and trees of alder, swamp-maple and willow were interlaced with blackberry brier, poison oak, and the rankest growth of nettles. All the while we were assailed by an increasing mob of starving mosquitoes that went raving mad at the taste of blood. We pushed on, straining, sweating, crawling, and climbing for a hundred yards that seemed more like a mile.

We forgot it all the minute we stood under the largest sycamore. It was seven feet thick at the base and difficult to climb. But this was the centre of business activity in the heron village. The monster was a hundred and twenty feet high, and had a spread of limbs equal to its height. In this single tree we counted forty-one blue heron nests and twenty-eight Night Heron (Nycticorax nycticorax 
navius) nests; sixty-nine nests in one tree. In another tree were seventeen of the larger nests and twenty-eight of the smaller.

The great blue heron or "crane" is one of the picturesque sights of every fish-pond and along the bank of every river and lake in the country. I look for him along the shallow sand-bars and sloping banks, as I look for the background of green trees. He is always the solitary fisher. He is the bit of life that draws the whole to a focus. Watch him, and he stands as motionless as a stick. He is patient. A minnow or frog swims past, and there is a lightning flash of that pointed bill as he pins him a foot below the surface. Disturb him and he deliberately spreads a pair of wings that fan six feet of air and dangles his long legs to the next stand just out of range.

Nature has built the heron in an extremely practical way. She dressed him in colors of sky and water. She did not plant his eyes in the top of his head as she did the woodcock, because he is not likely to be injured by enemies from above; but she put them right on the lower sloping side of his head so he could look straight down at his feet without the slightest side turn. She let his legs grow too long for perching conveniently on a tree-just so he could wade in deep enough to fish. She gave him a dagger-shaped bill at the end of a neck that was both long enough to reach bottom as well as to keep his eyes high above water, so he could see and aim correctly at the creature below the surface.

It is said that occasionally a pair of great blue herons will build an isolated nest, but I never found one. The 


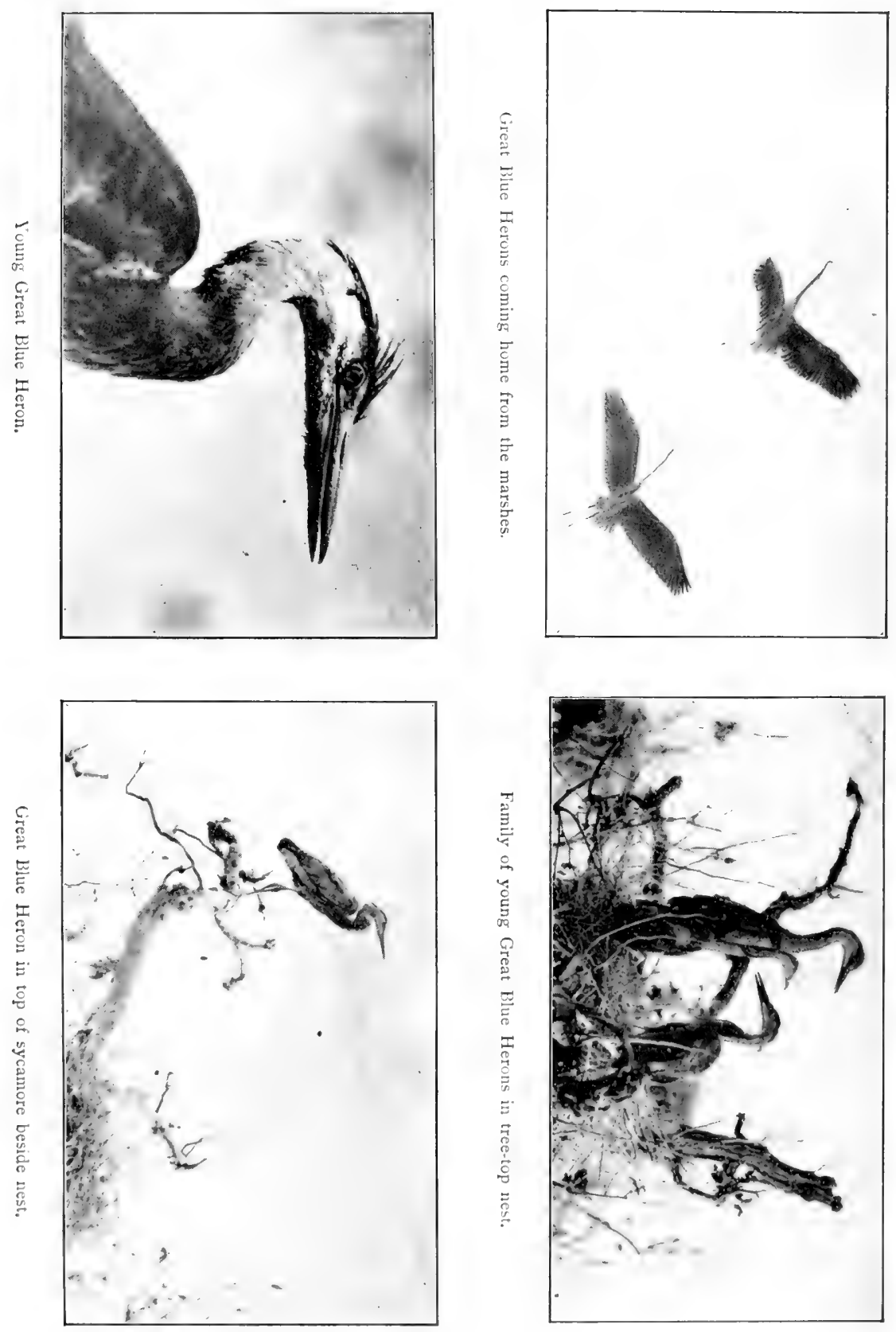
heron likes a remote fishing preserve of his own, but he loves to live in a small village community, to which he can return each evening and enjoy the social life among his neighbors and dwell in mutual protection.

$\mathrm{He}$ is a remarkable bird in adapting himself to circumstances. In a bird of such long legs and of such proportions, one would naturally think his nesting place would be on the ground. In the lake region of southern Oregon we did find the great blue heron nesting on the ground, surrounded on all sides by gulls, cormorants, pelicans, and terns. But in other portions of our country a colony of these same birds will select the tallest firs, deep back in the forest, or the sycamores, willows, and maples in the midst of a swamp.

We made the first trip to the heronry on April 2 Ist, and found that most of the nests contained eggs. There were about seven hundred nests in the whole colony, of which the larger number were black-crowned night herons'. The great blues and the night herons occupied the same trees, nesting side by side. The larger nests were built almost entirely in the tops of the sycamores, while the night herons set their platform nests at the very upturned tips of the sycamore limbs and in the lower surrounding willows and alders.

When I first climbed in among the nests of a smaller tree with my camera, it sounded as if I were in the midst of a gigantic hen-house. Some of the birds were clucking over their eggs that were soon to be hatched; others were cackling over newly laid eggs and squawking at being disturbed; others were wrangling and squabbling, so that there was a continual clattering fuss above which one had 
to yell his loudest to be heard. I sat astraddle a limb with my note-book in hand. About me, seemingly almost within reach, I counted thirty-six sets of blue eggs. I was high above the tops of the alders and willows. Set all about below in the background of green were the platforms, each holding several eggs of blue. The trees were dotted in every direction. I counted over four hundred eggs in sight.

The black-crowned night heron is a very different looking bird from the great blue. It has a shiny black patch on the top of the head, and a gray body with a black back. The short but thick neck and short legs are just the opposite of the blue heron. The night heron, as the name signifies, is not seen or heard much during the day unless you visit one of their colonies, which is placed generally in some almost inaccessible swamp. As long as these birds can find some protected place to nest they are sure to remain in spite of our civilization, for a colony of several hundred of them still nest in the maples of a dense swamp only a few miles from New York City.

Great blue herons perched lazily in the tops of the trees. Looking in one direction I counted over a hundred of them. They were sailing in continually and departing. The night herons fluttered about in a jerky, labored flight, lighting in the willows and hovering over their nests.

A night heron's or, as often called, a " squawk's " nest looks to me like a mere botch. Some of them are not hollowed in the least, but just rough platforms. In a wind the eggs would roll off if the mother did not sit to hold them on. There is not much trouble after the eggs are 


\section{In a Heron Village}

hatched, for the youngsters seem to kick themselves loose from the shell with one foot, while they wrap the long angular toes of the other about the nearest twig.

On our first trip to the heronry, when the nests contained eggs, we selected one or two of the best and most available to get a good series of pictures showing the growth of the young. Most all the night heron nests contained four eggs. The eggs seemed to hatch in regular order about two days apart. When we photographed the same nest later we found it held three frowzy-headed youngsters and one egg. On our third trip, the growth, both in size and ugliness, was quite apparent. On our next trip we found the nest deserted.

The next time I sat in the tree-top the place sounded more like a big duck ranch. Above all the squawks of the parents there was a steady quacking clatter of the hundreds of young herons, that never ceased. The sound grew more intense in spots, as here and there a mother swept in from the feeding-ground and fed her children. As I sat watching, an old blue heron sailed in and lit on a branch above her nest in the adjoining tree. The three youngsters twisted themselves into joyful shapes as the mother stepped awkwardly along the limb. Each reached up in full height to grasp her long bill. She sat on the nest, calmly looking about. The young continued to catch her long beak and pull it part way down, trying to make her feed them. When she got ready she disgorged a mess of partially digested fish down the throat of each nestling and left as leisurely as she came. In another case where the young were older, I saw the mother bird disgorge into the nest. The mass of undigested fish in her craw seemed 
to form into small portions and come up as the cud of a cow does, and each youngster pitched into the meal with a vigor and energy that would have amazed a litter of young pigs.

When you climb anywhere near a nest after the young birds have had a good meal, they will begin to "unswallow" as fast as they have gobbled it down. On account of this habit, especially common among night herons, we found it always safe to keep out of the way as much as possible, or at least not approach a nest full of young birds from below.

In order to study the life of the herons and get some pictures early in the morning before the wind sprung up so strong that we could hardly hold ourselves in the treetop, which it had a habit of doing at that season of the year, we camped at the heronry all one night. At the south end of the heron jungle is a hay-field, where we took up our quarters. We had no trouble in keeping awake most of the night to study heron habits. The blue herons as well as the squawks, or night herons, seemed to keep busy most of the night. As some one has said, it sounded as if several hundred Indians were trying to throttle each other. Then the mosquitoes and frogs were more active after dark. We crawled into a haycock and covered ourselves up, as much to get rid of bloodthirsty insects as to keep warm. At daylight we felt as much comfort in crawling out to get rid of burrs and stickers as we had the night before in crawling in to get away from mosquitoes.

A young night heron is well adapted to climbing from limb to limb by reason of his long angling toes and the ability to hook his neck or bill over a limb and draw him- 


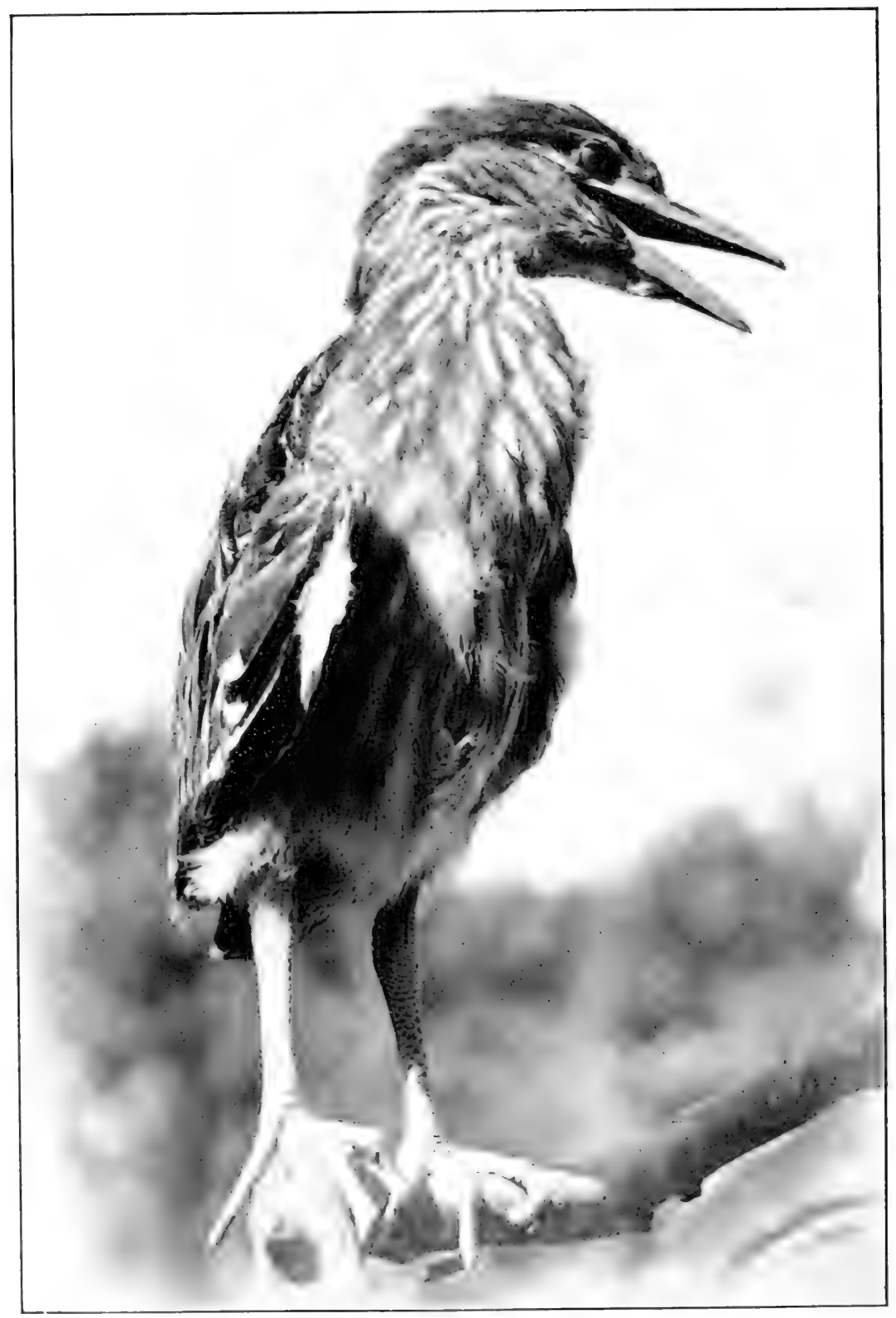

Full-grown young Night Heron. 


\section{In a Heron Village}

self up as a parrot does. Not so with the young blue herons; they are as awkward about the limbs of the trees as their parents are stately in moving through the air. When overbalanced on a limb they often fall to the ground.

The young birds of both species seem instinctively to know that falling from the trees to the ground below means death. Not because they are hurt in the least by the fall, but because the old birds never descend to the ground below the nest tree. The ground under the trees was strewn with the dead bodies of young birds. The young are fed only in the tree-top, and those below starve in the very sight of their parents.

Several times we saw young night herons hanging dead in the branches of the trees. In one tree we found two of these youngsters hanging side by side only a foot apart. In walking about the limbs, the larger of the two birds had caught its foot in a crotch and hung itself head downward. That, in itself, was not unusual, but the second bird hung by the neck only a few inches away. It seems that this smaller heron had hung himself dead rather than fall to the ground; he had fallen or overbalanced on the small limb and, as is the custom, had hooked his chin over the branch to keep from falling to the ground. His clutched right foot showed that the death struggle had been a reaching and stretching to gain the limb. The head was not caught between the branches as was the other bird's foot, but was simply hooked over the bend in the twig. Had he thrown his head back a little he would have dropped to the ground. We demonstrated this by turning the bill to an angle of forty-five degrees, and the 
body dropped to the bushes twenty feet below. How the bird could have held the rigid position of the neck throughout its death struggle I could not understand, unless it was a case where the force of instinct was strong even to death.

The last trip we made to the heronry we found the limbs of the sycamores as well loaded with young herons as a good apple tree is loaded with fruit. The moment we started to climb the tree with our cameras was the signal for the breaking loose of a squawking bedlam. Young squawks jabbered all sorts of epithets from the nest edge and retreated along the limbs as we drew nearer. The young blue herons savagely disputed every foot of the way. They aimed a fusillade of stabs at us from all sides, and we took great care not to get within reach of their weapons. When we did get into the tree-top it took some little time to oust a pair of enraged youngsters so that we could sit in their nest and aim the camera at the birds about.

It was considerable trouble for us to get a series of heron pictures. We suffered and scratched for weeks with a miserable rash from the poison oak, but we made five long trips to the heron village. The last trips through the jungle were not as difficult as the first; we had the beginning of a path and we took poison oak preventives: gloved our hands and veiled our faces. But it was worth it all just to get a clear idea of what life is in a big heronry. It was a sight for the soul just to watch the great blue herons; the long, slow wing-beats as they flapped in from the feeding-grounds; then the picture of quiet restfulness as they lounged about their nests after the day's work. 

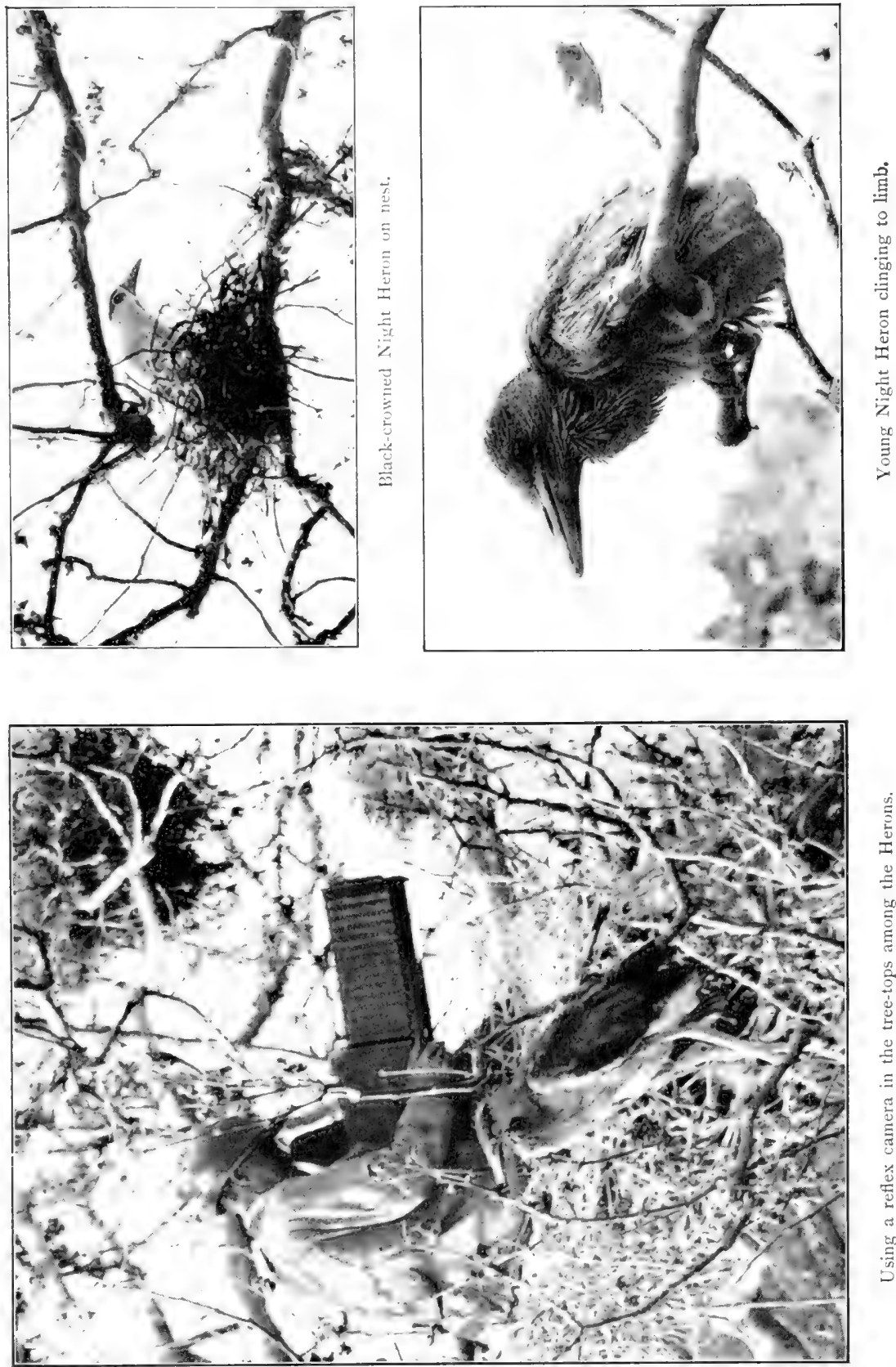



\section{In a Heron Village}

\section{THE HERON FAMILY}

The herons are wading birds that may be found along the banks of rivers, ponds, and through the marshes. The Great Blue Heron is a bird of great size, about four feet in length, with long neck and legs. With long, spearlike bill, the bird wades stealthily watching for fish. It has a heavy flight, moving along with big, slowly flapping wings. The Night Herons are much smaller, only half the size of a blue heron, and may be recognized by the stout bill and short, thick neck.

Great Blue Heron (Ardea berodias): Male and female, upper parts, bluish-gray; top of head white with long, black crest; feathers about neck, long and loose; shoulders, black striped with gray; under parts, streaked with black and white; thighs and edge of wings, cinnamon-brown. Ranges through North America at large and can be recognized by its large size and long legs. Nests in colonies, generally in tall trees. Three or four large eggs of bluish-green.

Black-crowned Night Heron (Nycticorax nycticorax navius), Squawk: Male and female, crown and back, black; wings and tails ashy-gray; forehead and throat, white, shading into light gray on side, and under parts. Common summer resident on Pacific and Atlantic Coast, arriving in April and staying till October. Nest, a mere platform of sticks in the tree-top. Eggs, three or four, pale sea-green. 

THE EAGLE OF MISSION RIDGE 



\section{XXI}

\section{THE EAGLE OF MISSION RIDGE}

ANY years ago a pair of Golden Eagles (Aquila 1 chrysaètus) came to live on the southern rim of Mission Ridge. The good people of the lower slopes said the birds were there before they came. The nest was first found by an egg collector in the early nineties, and for several years the big birds were robbed. Then the eagles would have no more of this and left their aerie. But each year they were seen about their old hunting-ground. The new aerie was still somewhere about the ridge, and this was the object of our quest. We wanted to study and photograph this royal pair of birds.

It was the morning of the twenty-fifth of March when we boarded the south bound train at Oakland and landed in a fertile, hilly district. With our cameras strapped to our backs we wheeled rapidly over the first few miles of road, but had to pile our bicycles in the brush about sun-up.

The spring rains had not yet ceased. The grasscovered fields were soft and springy under foot. A rich, earthy odor breathed gently up, and the nostrils failed not to take eager note of it. The air seemed to vibrate at every sound or motion. A band of red-wings held a song service just down the hill where the lush grasses grew. Meadow larks piped and whistled, blue jays squawked, 
and hummingbirds flashed about newly opened flowers. As we ascended out of the cultivated district the hills were splashed and streaked with yellows and blues and purples of the wild flowers-golden poppies, yellow mustard, and buttercups and purple lupines. Further up the road ceased and we had to follow a cow trail. After we reached the highest shoulder of the range we found the surface rocky and broken. There was scarcely any vegetation on the ridge except a scraggly growth of poison oak and chaparral. We stood long and gazed at the wide stretch of the whole valley. Far below and reaching inland from the lower end of San Francisco Bay the ribbonlike sloughs wound in and out, reaching far back like the tentacles of a huge octopus.

At the very top of the range the mountain breaks abruptly off into the head of the big cañon. This is the native haunt of the golden eagle. A large sycamore tree is rooted in the bed of the little stream. Four good-sized trunks rise from the giant roots. To the branch bending toward the valley, above the steep rocky slope, the eagles had carried a small cart-load of sticks and worked them into the forks where they branched, horizontal to the ground. It was a platform five feet across, not carelessly put together, but each stick woven in to add strength to the whole structure, as the stones are built into a castle.

Climbing one of the other trees the photographer put up a tiny platform in the topmost branches, where the camera was fastened and aimed downward at the aerie twenty feet away. Nor was it an easy matter to photograph in the top limbs of that sycamore, where a wrong 

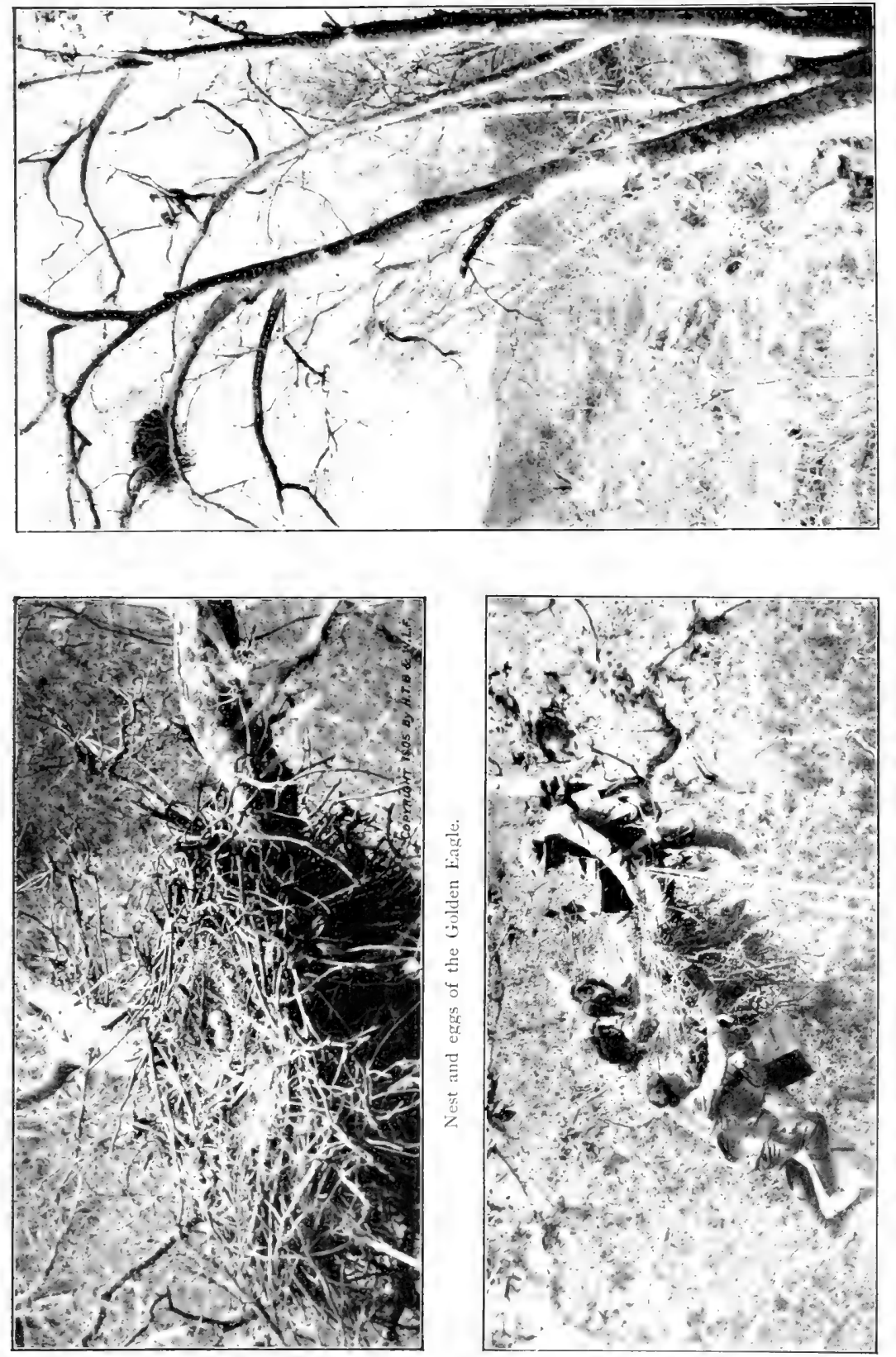


$$
\text { . }
$$

. 
move might land camera and all in the bed of the cañon. But for six different trips, extending over a period of two months and a half, we took pictures from this position and from the limbs near it.

"Did the old eagle show fight?" is the first question put by the usual listener. I always see a trace of disappointment sweep over his face when he hears the answer. The moment you speak of climbing to an eagle's aerie the average man gets an idea of the photographer hanging to the edge of a cliff or the top of a tree, with the old eagles clawing out pound chunks at every swoop. Few eagles possess the mad ferocity pictured and magnified by sensational story tellers. When we first scrambled over the bowlders of the cañon up toward the nest, I saw the old eagle slip quietly from her eggs and skim out over the mountain top. When I strapped on the climbers to ascend the tree, I had one eye open for trouble. But each time we visited the spot the parents silently disappeared, and stayed away as long as we cared to remain. They kept a watchful eye, however, from the blue distance overhead. For a noble bird like the eagle this forsaking of the nest and young seemed cowardly at first. But perhaps the long years of persecution have taught him something. The first rule of safety of this pair seemed to be to keep half a mile distant from man, the animal that fights with neither beak nor claw.

Our work at the eagles' nest shows well the necessity of a good series of lenses when one is photographing in the tree-tops. The camera was fastened in a crotch in an adjoining tree, twenty feet from the nest, where it could not be moved forward or back. By adjusting the wide- 
angle lens we could get a view of the nest and surrounding limbs, and at the same time have a depth of focus that showed the outline of the valley lying miles below. By the use of the regular lens the nest was brought nearer the camera, and still the sweep of the rocky side of the cañon was retained. The single rear lens gave a different picture, narrowed down to the outer end of the large limb containing the nest. Our telephoto lens had the power of bringing the nest as close as we cared to photograph it, covering the full size of a $5 \times 7$ plate and giving a clear definition of the lining of the nest.

One cannot help feeling the dangers of climbing about the limbs of a tall tree, but it always doubles his caution when he has to maneuver in the topmost boughs, carrying a camera that has cost him over two hundred dollars. One day we narrowly escaped an expensive accident. We were hoisting our cameras and half way up one of the lines broke. Fortunately I was below, ready for such a mischance, and as the camera shot downward I spread my hands in the nick of time to stop the fall. It knocked me backward, and the camera would have bounded over the edge of the bank and been smashed on the rocks fourteen feet below had my fingers not closed on the piece of rope as it slipped through my hand.

The golden eagles are mated for life. During the month of February the aerie was recarpeted with small twigs and dry leaves, for the eagles of the summer before had worn it down to a rough platform of sticks. A hollow of this soft material was made in the middle for the eggs, and a branch of green laurel was added. Later on when I removed this branch of evergreen it was promptly 
replaced by another piece that had been wrenched from the living tree by the eagle. When this second piece had dried still another branch was added. This badge of green seems to be as necessary in the eagle's home as the sacred Lares at the Roman fireside.

At this time the pair of great eagles were inseparable, and they generally hunted together. For days before the mother cradled her eggs they sat for hours at a time close together on a great limb near the aerie. They had several such favorite perches where they sat and watched the rugged mountain sides for food. They were far up the slope where they could look off over the whole sweep of the ridge.

The fog was hanging heavy and wet as we climbed slowly up the mountain the second time, and the tall grass and bushes drenched us at every step. We had started under a clear sky with the stars shining, before the first streak of dawn appeared in the east. At daybreak the cool breath of the sea air began to sweep in through the Golden Gate and up the valley, carrying and lifting the fog as it came. And as the last mist clouds were swept along with their fingers trailing in the scraggly bushes, the great eagle with his crown of burnished gold floated out from the head of the cañon. It was his duty to forage. The mate of sombre black stayed on the nest. She had not left since yesterday noon. For over four weeks she had warmed the two eggs, and now she had twin eaglets at her breast. Instead of leaving her young when we were half a mile down the cañon, as she did when the nest contained eggs, the mother crouched flat down while we climbed the mountain side above the tree and looked at her through 
the field-glass. But she slid off soon after and sailed awisy when we started to climb the tree.

Sixteen days later we were in the big sycamore again. By that time the eaglets had grown from the size of an egg to that of an ordinary chicken, but they had not begun to change from the color of snowy white. They lay crouched in the nest, clumsy in body, and watched us angrily with their wild dark eyes. They resented my company when I climbed into the nest and planted the camera right beside them. At that time they were not strong enough to offer much resistance; they could not help being imposed upon. They endured silently, laying up wrath for the days of strength when they could strike a blow that would bring the blood.

The growth of the young eagles was very slow but steady. Fifteen days after our last visit we found that the stiff, black feathers were beginning to push their way through the thick coat of white down, and the eaglets took on a mottled appearance.

When we again started up the mountain to visit the aerie we struck a heavy wind-storm driving down over the hills. We could hardly climb in the teeth of the gale. I can never forget the sensation as we crossed through the last fields of standing grain. The wind cracked and lashed the tall stalks till it seemed we were in the midst of raging waters. From the ridge we sat and watched the enormous silvery serpents that wriggled up and down through the standing grain, as gust after gust swept along the slope. Where the grain had been cut and shocked the gale created havoc by scattering it broadcast down the mountain side. But the most difficult task was to 

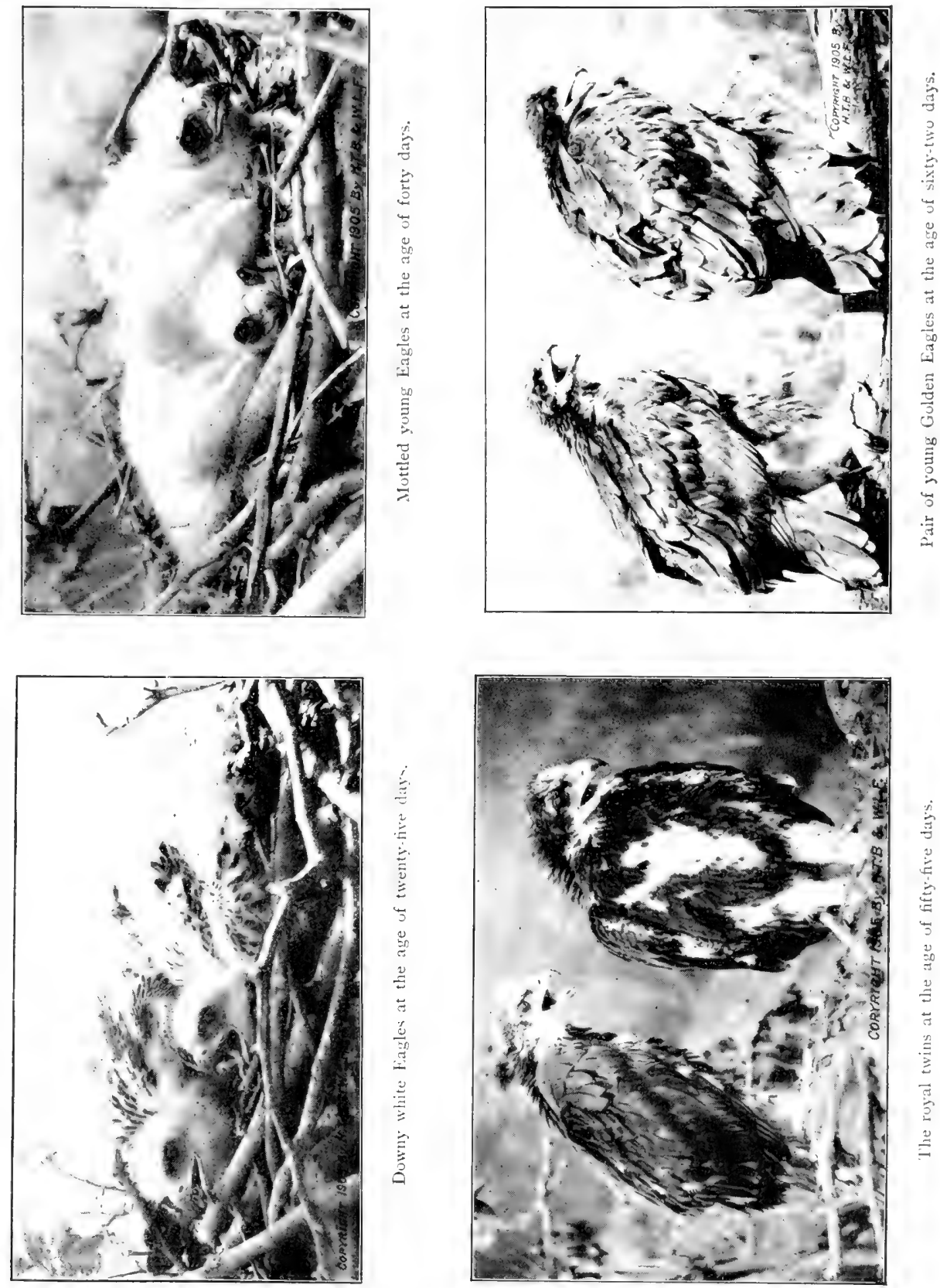


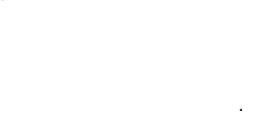


climb the eagles' tree and get pictures in the swaying branches.

We found the golden eagle a valuable inhabitant of any cattle-range or farming community. His food consists almost entirely of the ground squirrels that are so abundant through the California hills and cause such damage in the grain-fields. Once when we looked into the nest we found the remains of the bodies of four squirrels lying on its rim. At each visit we examined the food remains about the nest, and I am sure that a very large amount of the eagle's food, if not all, consisted of squirrels. The hills in many places were full of their burrows, and the eagles seemed to have regular watch-towers on the high rocks about, from which they swooped down on their prey. If it were not for the birds of prey about these hilly districts, some of the places would surely be overrun with harmful creatures of the ground.

I am satisfied that this family of eagles ate six ground squirrels a day during the period of nesting, and very likely more than that. Those young growing eagles surely needed a fair amount of food each day for about three months, and they were well supplied, to say nothing of what the old birds ate. But even this low estimate would mean the destruction of five hundred and forty squirrels along the hillsides in about three months' time. What would be the total if we estimated the killing for the entire year? This is the permanent home of the eagles and of all the families of hawks and owls along the hills and cañons.

Near the end of our visits to the eagles' nest the country had changed its appearance. The hillsides had lost 
the color of green. The sun had baked the pasture-land into granite hardness. Every blade of grass was burned dry and crisp, making the steep slopes almost too slippery for foothold. The heat of the sun's rays had licked up every drop of water in the long series of side cañons through which we had to pass. With our heavy cameras on our backs we struggled slowly up the rugged slopes, slipping and perspiring, our tongues parched with thirst. At dark we ate our supper and gladly stretched ourselves under a tree for the night, a'mile down the cañon from the eagles.

When the first gray light of the morning crept down the western slope of Mission Ridge the king and his widewinged mate soared out over the shadow of the sleeping world. The nestlings were almost full-grown. They stirred about and kept a hungry lookout from the nest edge and the great limb-perch of the parents. At the first sight of food they lifted their wings in strange and savage ecstasy. They were no longer fed, nor did they share the headless body of the squirrel that was dropped in the aerie. One rended it in bloody strips and swallowed it in gulps, while the other held sullenly aloof, awaiting the return of the mate with its breakfast.

I cannot imagine even a touch of humor in the life of the eagle. A pair of blue jays nested near the eagles, and I imagine they came sneaking around at times when the parents were not at home, just to see what was going on. One day I was sitting on the edge of the nest with my feet dangling over, when one of the curious jays came up from behind. He didn't notice me till he alighted, squawking, close by. His squawking-valve 
closed short off with a squeak of surprise; he threw up his wings in horror and fell backward. The blue jay himself would have chuckled in enjoyment at the sight, if the joke had not been on him. I enjoyed it hugely, but it was all Greck to the eagles. Everything to them is serious. Life is a cruel, harsh reality; it is blood from birth to death.

The golden eagle appeals to me as a real baron of the middle ages, with his castle and his hunting preserve. The sycamore is his permanent home, the heavens above the ridge and the low-lying fields are his with no questioning, summer and winter. $\mathrm{He}$ is more than a match for any animal of his size. Not a beast of the field nor a fowl of the air can drive him out; he stands firm before every earthly power, except the hand of man. He is shy and wary at all times, clean and handsome, swift in flight, and strong in body. An experience gained in the fiercest of schools makes the eagle as formidable as any creature of the wild outdoor.

The eagles revolted at the sight of a human being. They opened their mouths in defiance when we first looked over the nest edge, nor were they one whit less savage for all our visits. From the first they would have rent to shreds the hand that dared touch them. They submitted to us as a caged lion endures his keeper. Meekness and mercy are no part of the life of the eagle. Theirs was a savage spirit that could no more be tamed by the human hand than could the hooked beak and claws be changed. Deep-set under each shaggy brow was an eye of piercing glare, that seemed always searching the far-away blue of the distance. It was the eye of an eagle, and nothing else 
can describe it. After three months of human acquaintance, it was the real king of birds that left the birthplace, never again to be touched alive by the hand of man.

The golden eagle was formerly found east of the Mississippi as well as west, but it does not now frequent the more settled portions. A single pair may still live in the wildest regions of New England or northern New York, or a few may still have their homes in the mountains of the two Virginias, Kentucky, Tennessee, Georgia, or the Carolinas. The bird is not common anywhere, yet it is still found in the mountainous regions of the West, especially in portions of California. In the Rocky Mountains the golden eagle often builds its nest on the high cliffs, but in California and Oregon its favorite nesting sites are the pines, oaks, or sycamores of the deep cañons or the rugged slopes.

Although still found in the wilder regions of California these birds have suffered a great deal from collectors during the last decade. Their habit of occupying the same aerie year after year enables the collector, after once locating the nest, to make his yearly raid to advantage, as the eggs are rare enough to have a good market value. One nest was robbed for three successive years and the female killed, but the male secured another mate and kept the same nest the following season. But where the eagles are robbed continually for several years they are sure to be driven away. They have entirely disappeared from certain places where they were once regular residents.

In several cases I have known the golden eagle to show as marked an individuality as a person. In one aerie that was used a pair of birds showed a peculiar liking for 
a bulbous plant, commonly known as the Spanish soaproot, and every year they adorned the nest with the large hairlike top of this plant. Another case is on record where the eagle had a peculiar liking for grain sacks, which were used in the lining of the nest. The first time this nest was discovered it contained a large grain sack, but the storms of the following winter dislodged the nest. The new nest that was built the following year was again lined with a grain sack.

It is often the case that a pair of eagles will inhabit the same locality for several years and make no attempt at rearing a brood. Perhaps these are young eagles; many birds do not breed till after the second or third year. In other instances, a pair will repair an old nest and stay about all the nesting season, and yet not go to housekeeping. In a few rare instances the golden eagle has been known to lay three eggs, but two is the usual number.

What does such a series of pictures represent? Three months of patient waiting, varied by six long mountain trips of two days each; backaching tramps up trails to the summit of a rock-strewn ridge, with a heavy camera equipment; and the snapping of over a hundred $5 \times 7$ plates, exposed at every available view of the stronghold from terra firma to tree-top.

We made a careful study of the nesting habits of a finch to serve as a comparison between the small seedeating birds and the largest birds of prey. I found the finch building its nest and watched it closely. The home was lined and completed June 24th. It contained three eggs on the twenty-seventh. On July 6th the eggs hatched, and the young were able to leave the nest July 
I 6th. In other words, it took nineteen days for the finches to hatch the eggs and rear the family, or about four weeks to build a nest and send the young birds forth into the world.

How does the eagle compare with the finch? The same aerie was used year after year. Two dull white eggs, shell-marked with brown, were laid the first week of March, just as the sycamore was beginning to bud out. The period of incubation lasted about a month, for the eggs were not hatched till the third of April. The eaglets were covered with soft, white down soon after hatching. White is not the color for a hunter, but these snowy garments lasted for a full month, during which the youngsters grew from the egg to the size and weight of a large hen. The first week in May black pin-feathers began to push up through the down, first appearing on the wings and back. Week after week the stiff feathers grew, but they came slowly, covering the back, wings, head, and neck, until by the first week of June the eaglets were fairly well clothed in a bristling suit of dark brown and black, except for a small white shirt front. The wings and feet were still weak. It required over three weeks longer for the wing feathers to gain strength and the feet to grow powerful enough for the birds to handle their heavy bodies. So, where the finch required four weeks to rear a family, it took the eagle a good four months.

\section{THE EAGLE FAMILY}

The largest bird of prey, known as king among birds. A bird of great size and powerful on the wing. It is a rare occasion when one gets a near view of one of these wild birds; they are often seen high in the 


\section{The Eagle of Mission Ridge}

air, where they soar in great circles. Length, about three feet; extent, about seven feet. Female larger than male.

Bald Eagle (Haliaëtus leucocepbalus), Bird of Washington, selected as our national emblem: Male and female, head, neck, and tail, snowywhite, rest of plumage blackish or dark brownish. The young birds during the first year are wholly black. Lives largely on fish, diving for them, stealing them from the fish hawk, or finding dead fish cast up by the waves. Lives throughout the United States.

Golden Eagle (Aquila cbrysaëtus): Male and female, entire plumage dark brown; back of neck and feathers on legs lighter brown; legs feathered to toes. Lives in the wilder parts of North America, where it builds a big platform nest in trees or on the ledge of a cliff. Eggs, generally two, whitish, marked with blotches of brown and gray. Lives largely on mammals and birds, including squirrels, prairie-dogs, rabbits, grouse, and water-fowl. 


$$
\text { . }
$$




\section{N D E X}

A

American Barn Owl.............................. $8_{\mathbf{I}}-88$

" Crow..........................69-77

“ Redstart............................. 134

“ Robin................................208

Anna Hummingbird...........................

Audubon Warbler............................... 135

B

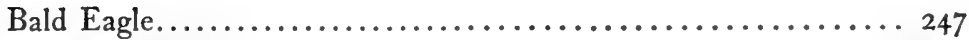

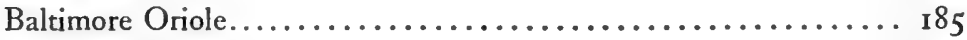

Barn Owl...................................

Bee-martin................................ 195

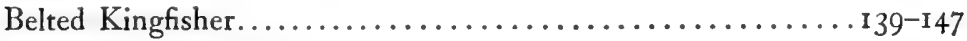

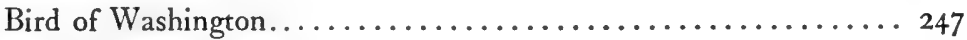

Black and White Warbler.......................... I34

Blackbird............................... 206

Blackburnian Warbler......................... I34

Black-capped Titmouse........................ I6

Black-chinned Hummingbird................... I 76

Black-crowned Night Heron.................... 221-23I

Black-headed Grosbeak........................... $45-53$

Black Phoebe............................... 195

Black-poll Warbler............................. I34

Black-throated Gray Warbler...................... 127-135

Black-throated Green Warbler..................... 134

Bluebird...................... I57, I6 $3,165-172$ 
Bluebird, Western.......................... I 72

Blue Jay........................... 129, I63-165

Blue-winged Warbler......................... I34

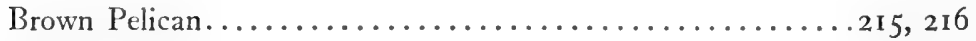

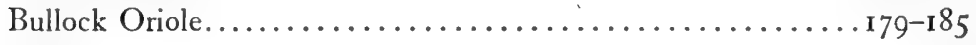

Bush-tit............................... 105-I I I

Butcher-bird........................... I 5 5 123

\section{C}

California Jay........................... r

" Shrike......................... II $5^{-123}$

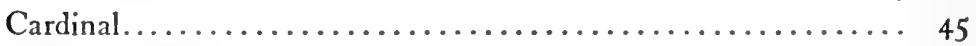

Cassin Vireo.......................................... 85

Chestnut-sided Warbler.......................... I34

Chickadee........................... I5-22, Iog

" Western............................... 22

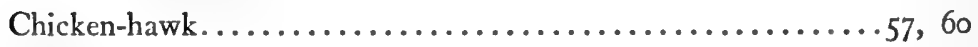

Chippie................................... r6o

Chipping Sparrow............................ I6o

Cooper Hawk............................... 4r

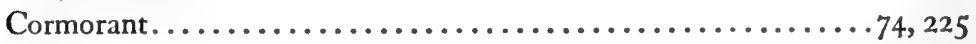

Crane..................................... 224

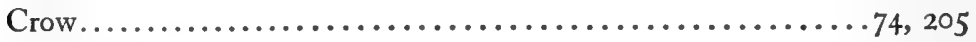

"American.....................................69-77

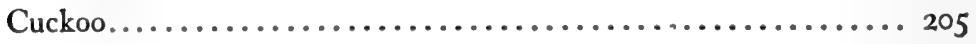

D

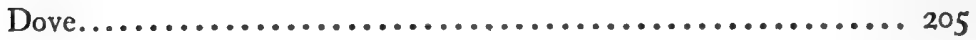

E

Eagle, Bald.................................. 274

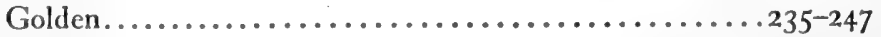

English Sparrow...................... 81, 151, 156-160 
Flicker......................... 21, 35, I42

" Red-shafted..........................25-32

Flycatcher............................... 47

\section{G}

Golden Eagle..............................235-247

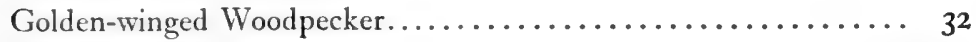

Great Blue Heron........................221-23r

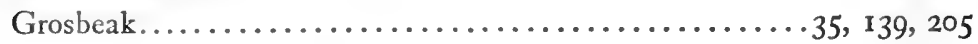

" Black-headed...........................45-53

“ Rose-breasted...........................46, 52

Gull..................................... 74,225

" Herring................................ 217

"Western.........................

\section{$\mathrm{H}$}

Hair-bird............................... 160

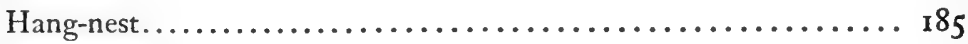

Hawk, Cooper................................. 4r

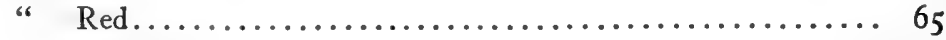

" Red-tailed............................... 57,65

" Sparrow............................. $1 \mathbf{1 3}$

" Western Red-tailed........................... $57-65$

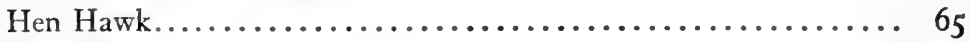

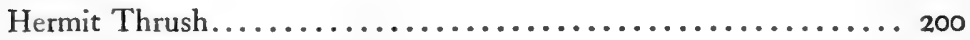

Heron, Black-crowned Night....................221-23I

، Great Blue.........................221-23I

Herring Gull.............................. 217

High-hole................................... 25-32

House Finch...................... 189 
House Sparrow........................... 159-160

"Wren............................. Iо I

Hummingbird............................. 139

Anna......................

Black-chinned................ I 76

Ruby-throated.................... I I I

Rufous........................ $3^{-11}$, 76

\section{$\mathrm{J}$}

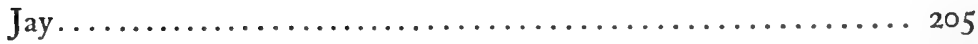

"Blue...................... 129, I63-165, I71, 242

" California.............................. 171

$\mathrm{K}$

Kingbird............................... 195

Kingfisher, Belted....................... 139-147

L

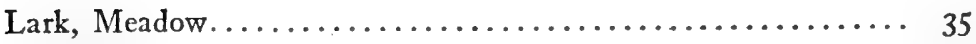

Least Vireo............................ 185

Linnet, Red-headed......................... r 190

Linnet (House Finch)..................... I89-191, 195

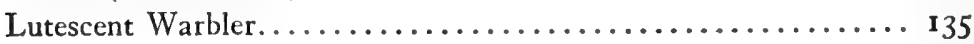

M

Macgillivray Warbler........................ 4I

Maryland Yellow-throat........................ 4I

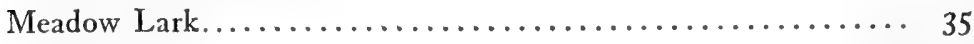

Mockingbird............................ I 8 , I 9

Mourning Warbler............................ 4I

Myrtle Warbler................................ I35 
Nashville Warbler.

Nighthawk.

Northern Shrike.

Nuthatch, Red-breasted.

\section{$\mathrm{O}$}

Olive-backed Thrush............................... 208

Oriole.......................................... 205

"Baltimore................................. I85

“ Bullock..........................................

Osprey......................................... 62

Owl........................................ 47

“ Barn...............................

\section{$\mathrm{P}$}

Parkman Wren.......................... I01, I57

Parula Warbler.................................. I 134

Pelican.................................... 74,225

" Brown..............................215, 216

Pewee, Wood.................................. 195

Phoebe...................................... 195

“ Black................................. $189-\mathbf{1} 95$

$\mathrm{R}$

Red-bird.................................... 45

Red-breasted Nuthatch............................ 93

Red-eyed Vireo................................ 185

Red-hammer................................ 25, 27, 28

Red Hawk....................................... 65

Red-headed Linnet............................. 190

Red-shafted Flicker.............................. 25-32

Redstart, American.............................. I34

Red-tailed Hawk.................................. 57,65 
PAGE

Robin, American............................. 208

“ Western.......................47, 48, 199-208

Rose-breasted Grosbeak......................... 46, 52

Ruby-throated Hummingbird...................... Io, I I

Rufous Hummingbird.......................... I I 76

Russet-backed Thrush.................... I99-203, 208

Screech Owl............................... $6_{4}$

Shrike, California............................. 15 - 123

" Northern............................. I23

" White-rumped......................... 123

Snipe.................................... I39

Song Sparrow............................. 151-153, 160

Sparrow, Chipping........................... I6o

" English..................... 1 I, I5 $1,156-160$

" Hawk............................. 213

" House............................ 159, 160

" $\quad$ Song.......................... 151-153, 160

" White-crowned.................. I51, 153-156, I6o

" White-throated......................... I6o

Squawk.................................... 226, 23 I

Street Gamin............................. I59, I60

Swallow.................................. 74, 165

Summer Yellow-bird............................. I34

Tern..................................... 225

Thrush $\ldots \ldots \ldots \ldots \ldots \ldots \ldots \ldots \ldots \ldots \ldots \ldots \ldots \ldots \ldots \ldots \ldots \ldots . \ldots \ldots \ldots$

" Hermit................................. 200

" Olive-backed............................. 208

“ Russet-backed......................199-203, 208

“ Veery................................200, 208

" Wilson.............................. 208 
Thrush, Wood................................200, 208

Titmouse, Black-capped........................... 16

Tramp.................................... 169

\section{$\mathrm{V}$}

Veery (Thrush)................................200, 208

Vigors Wren.................................

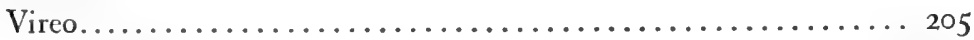

"Cassin........................................... 185

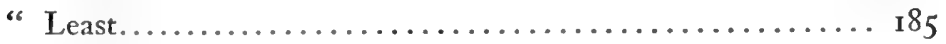

“ Red-eyed................................... 185

“ Warbling............................. 176-179, 184

“ White-eyed............................... I85

“ Yellow-throated............................ 185

Warbler..................................29, 205

" Audubon................................. I35

" Black and White............................ 134

“ Blackburnian................................ 134

“ Black-poll................................. I34

“ Black-throated Gray.......................127-135

“ Black-throated Green.......................... 134

“ Blue-winged................................ 134

" Chestnut-sided................................ 134

“ Lutescent.................................. 135

“ Macgillivray.............................. 4I

“ Mourning................................ 4I

“ Myrtle..................................... 135

“ Nashville.................................... 134

“ Parula.................................... 134

“ Yellow...........................47, 134, 202, 203

Warbling Vireo..........................176-179, 184

Western Bluebird............................. I72 
Western Chickadee........................... 22

" Gull..............................21 $1-217$

“ Herring Gull....................... 217

“ Red-tailed Hawk......................... 57-65

“ Robin..................47, 48, 199-208

“ Yellow-throat..........................

White-breasted Swallow.......................... 157

White-crowned Sparrow.................. 151, 153-156, I60

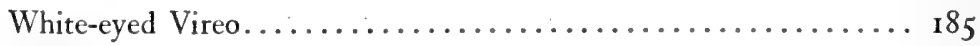

White-rumped Shrike......................... 123

White-throated Sparrow........................ I60

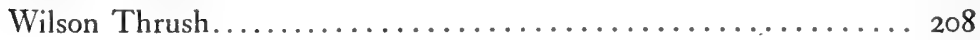

Winter Wren............................. 20 r

Woodpecker............................... I39

" Golden-winged...................... 32

Wood Pewee................................. 195

Wood Thrush..............................200, 208

Wren........................... 165, 192

" House................................ ror

" Parkman.......................... 10 1, 157

"Vigors..........................

"Winter.............................. ror, $20 \mathrm{r}$

Yellow-bird, Summer......................... 134

Yellow-hammer............................. 25, 32

Yellow-throat.................................. 45

“ Maryland...$\ldots \ldots \ldots \ldots \ldots \ldots \ldots \ldots \ldots \ldots$ 4I

" Western............................

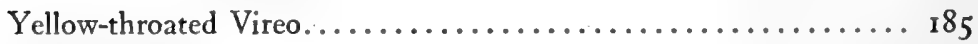

Yellow Warbler........................ 134, 202, 203 


\section{.}

- 


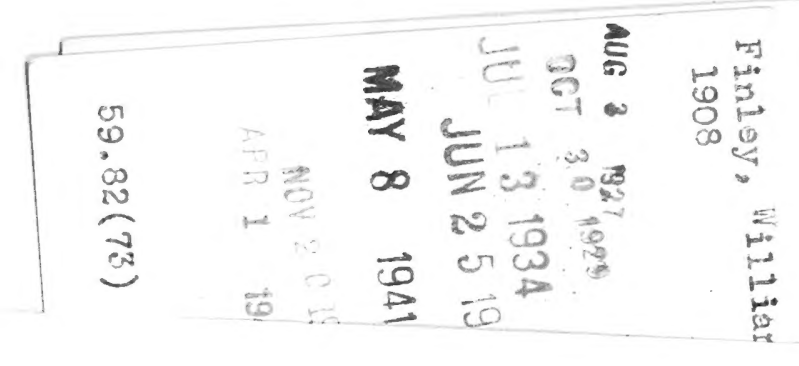




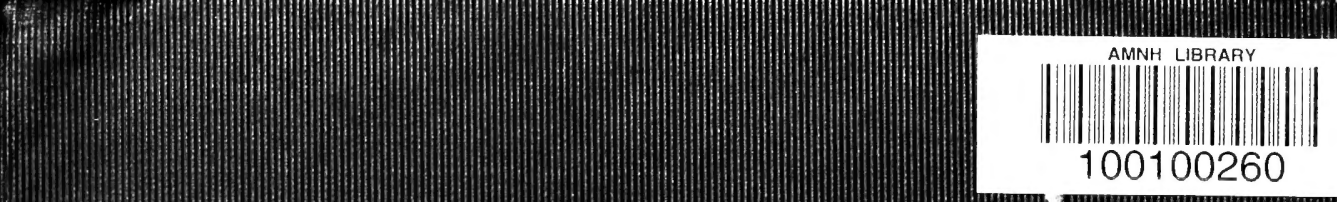
100100260

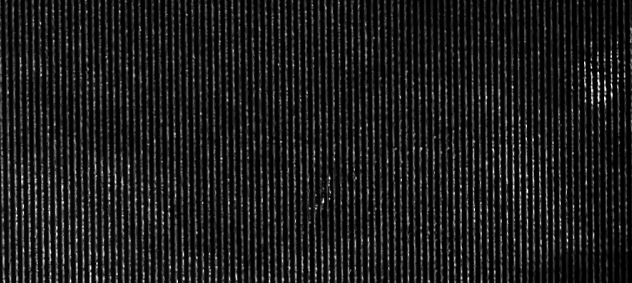

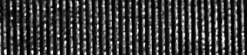

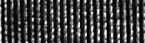

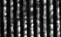

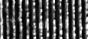

